Supporting Information for

\title{
Multicatalytic Approach to One-pot Stereoselective Synthesis of Secondary Benzylic Alcohols
}

\author{
Alessandra Casnati,\# Dawid Lichosyt,\# Bruno Lainer, Lukas Veth, and Paweł Dydio* \\ University of Strasbourg, CNRS, ISIS UMR 7006, 8 allée Gaspard Monge, 67000 \\ Strasbourg, France \\ \# these authors contributed equally. \\ * correspondence to: dydio@unistra.fr
}

\section{This file includes:}

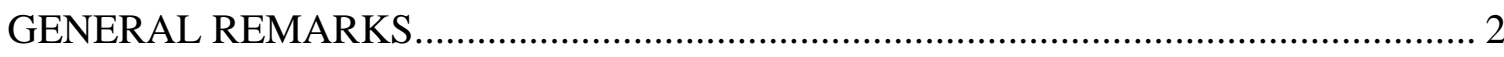

I. PREPARATION AND CHARACTERIZATION OF SUBSTRATES, LIGANDS,

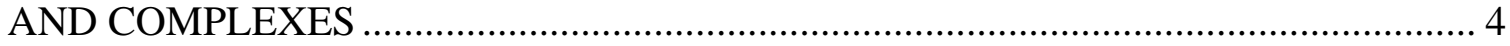

II. ONE-POT ISOMERIZATION AND ENANTIOSELECTIVE ARYLATION OF

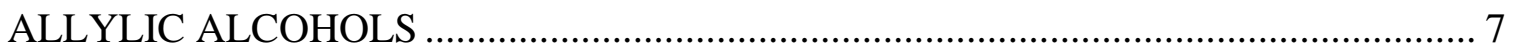

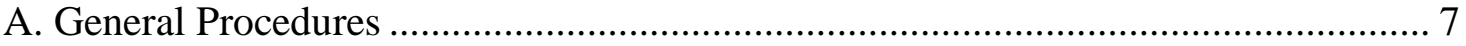

B. Full Characterization of Reaction Products .......................................................... 9

II. MULTI-CATALYTIC ENANTIOSELECTIVE CONVERSION OF ALKENES TO

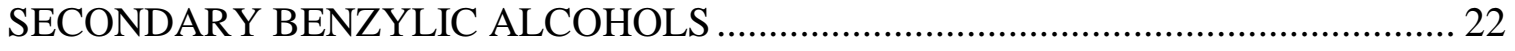

A. Optimization of the Reaction Conditions and Control Experiments ...................... 22

B. General Procedure ...................................................................................... 23

C. Full Characterization of Reaction Products ........................................................... 26

III. COMPARISON OF ONE-POT AND STEPWISE SYNTHESIS OF

ENANTIOMERICALLY ENRICHED 5,5-DIMETHYL-1-PHENYLHEXAN-1-OL.... 36

A. Optimization of the Reaction Conditions and Control Experiments ...................... 41

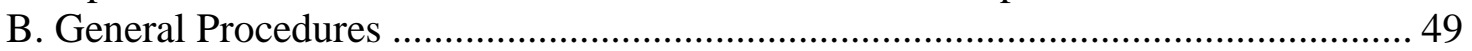

C. Full Characterization of Reaction Products ......................................................... 50

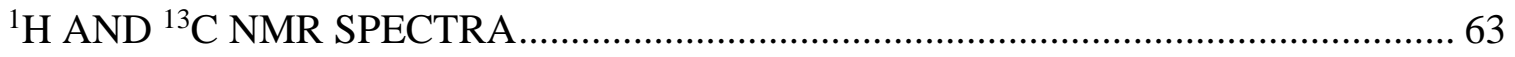

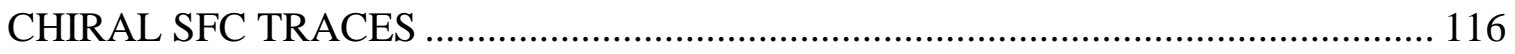

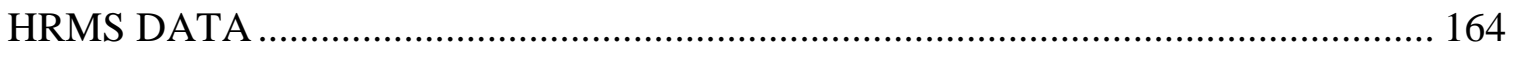

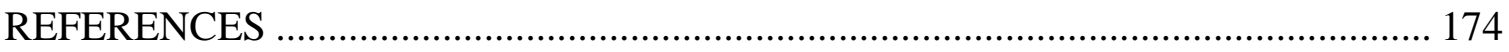




\section{GENERAL REMARKS}

Unless stated otherwise, all reactions and manipulations were conducted on a laboratory bench or in a well-ventilated fume hood in air with reagent grade solvents. Reactions under inert gas atmosphere were carried out in the oven-dried glassware in a nitrogen-filled glovebox or by standard Schlenk techniques under nitrogen. Unless noted otherwise, all reagents and solvents were purchased from commercial suppliers and used without further purification. For experiments under inert gas atmosphere, dry solvents like dichloromethane (DCM), tetrahydrofuran (THF), toluene, hexane, and diethyl ether $\left(\mathrm{Et}_{2} \mathrm{O}\right)$ dioxane, acetonitrile, 1,4-xylene, were purchased from commercial suppliers and used as received. Water was degassed by purging with nitrogen for $30 \mathrm{~min}$. Column chromatography was carried out either with the aid of CombiFlash EZ Prep Chromatography System with integrated ELSD using the RediSep Rf (Gold) Silica Gel Disposable Flash columns or with the aid of the Biotage Isolera instrument using Merck Kieselgel 60 (230-400 mesh). TLC visualisation was carried out with ultraviolet light (254 $\mathrm{nm}$ ), followed by staining with a $1 \%$ aqueous $\mathrm{KMnO}_{4}$ solution. NMR spectra were acquired on the $400 \mathrm{MHz}$ or $500 \mathrm{MHz}$ Bruker instruments at the Institute of Science and Supramolecular Engineering (ISIS) or at the Department of Chemistry, University of Strasbourg, Strasbourg. NMR spectra were processed using the MestReNova 10.0 software. Chemical shifts are reported in parts per million (ppm) and referenced to residual solvent peaks or tetramethylsilane (TMS). Coupling constants are reported in hertz (Hz). SFC analysis was conducted using an Agilent SFC 1260 Infinity II instrument connected to an Agilent MSD XT mass spectrometry equipment. Chiral SFC separation was achieved using Chiralpak SFC (100 mm x 3 mm ID x $3 \mu \mathrm{m})$ columns. GC-FID analysis was obtained either on a Shimadzu GC-2010 Plus instrument equipped with a SH-Rxi-5MS column (25 m x $0.20 \mathrm{~mm}$ ID x $0.33 \mu \mathrm{m}$ film) connected to a FID detector, or on a ThermoFisher TRACE 1300 instrument equipped with a HP-5 column ( $25 \mathrm{~m}$ x $0.20 \mathrm{~mm}$ ID x $0.33 \mu \mathrm{m}$ film) for achiral analysis or with an CP-Chiralsil-Dex CB column (30m x $0.25 \mathrm{~mm} \times 0.25$ $\mu \mathrm{m}$ film) for chiral analysis, connected to a FID detector. GC-MS analysis was obtained either on a Shimadzu QP2020 (EI) instrument equipped with a SH-Rxi-5MS column (25 m x $0.20 \mathrm{~mm}$ ID x $0.33 \mu \mathrm{m}$ film) or on an Agilent 7820A (G4320) equipped with a HP5MS UI column ( $30 \mathrm{~m}$ x $0.25 \mathrm{~mm}$ ID x $0.25 \mu \mathrm{m}$ film) connected to an Agilent MSD block 
5977E (G7036A). GC and NMR yields were calculated using 1,3,5-trimethoxybenzene, decane, or dodecane as the internal standards. GC yields were corrected for response factors for all compounds. Optical rotations were measured on a Perkin Elmer Precisely/Model-341 polarimeter operating at the sodium D line with a $100 \mathrm{~mm}$ path cell. High-resolution atmospheric pressure photoionization mass spectra (HR-MS APPI) were obtained on Thermo Exactive Plus EMR with a MasCom GC-APPI Interface (at ISIS). 


\section{PREPARATION AND CHARACTERIZATION OF SUBSTRATES, LIGANDS, AND COMPLEXES}

$(\mathrm{R}, \mathrm{R})$ - or $(\mathrm{S}, \mathrm{S})-\mathrm{Me}-\mathrm{BIPAM}{ }^{1}$ and sulpho ${ }^{2}$ ligands, as well as, Ru-2, ${ }^{3}$ (S)- or (R)-Ru-3, ${ }^{4}$ Ru- $\mathbf{4}^{5}$ complexes were prepared following previously reported procedures. Other ligands and complexes were purchased from common commercial suppliers and were used as received. All complexes and ligands were stored under inert atmosphere at $<-20^{\circ} \mathrm{C}$.

$$
\begin{aligned}
& \text { Ir-1: }[\operatorname{lr}(\operatorname{cod}) \mathrm{Cl}]_{2} \\
& \text { Ir-2: }\left[\operatorname{lr}(\operatorname{coe})_{2} \mathrm{Cl}\right]_{2} \\
& \text { Ir-3: }\left[\operatorname{lrCp}{ }^{*} \mathrm{Cl}_{2}\right]_{2}
\end{aligned}
$$

Ir-4: $\left[\operatorname{lr}(\mathrm{cod})(\mathrm{py})\left(\mathrm{PCy}_{3}\right)\right] \mathrm{PF}_{6}$

Rh-1: $\left[\mathrm{Rh}(\mathrm{cod})\left(\mathrm{CH}_{3} \mathrm{CN}\right)_{2}\right] \mathrm{BF}_{4}$

Rh-2: $\left[\mathrm{Rh}\left(\mathrm{C}_{2} \mathrm{H}_{4}\right)_{2} \mathrm{Cl}\right]_{2}$

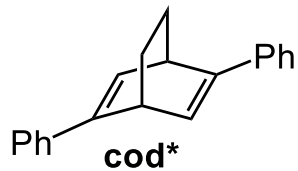<smiles>CC(C)(C)S(=O)N/C=C\c1ccccc1</smiles>

sulpho<smiles>c1ccc(-c2ccc3ccccc3c2-c2c(P(c3ccccc3)c3ccccc3)ccc3ccccc23)cc1</smiles>

(R)-BINAP

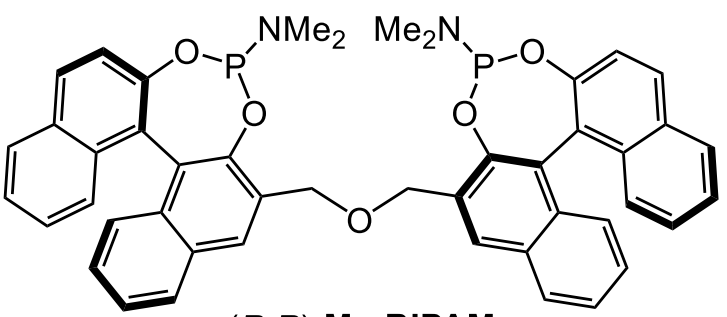

$(R, R)$-Me-BIPAM

\section{Ru-1: $\left[\mathrm{Ru}(\text { cymene }) \mathrm{Cl}_{2}\right]_{2} / \mathrm{Me}-\mathrm{BIPAM}$}

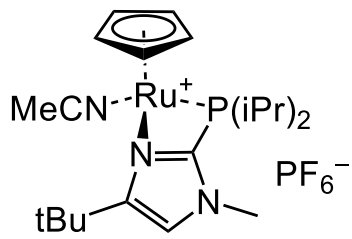

Ru-2: Zipper cat.

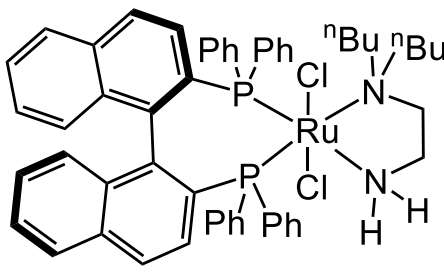

(S)-Ru-3

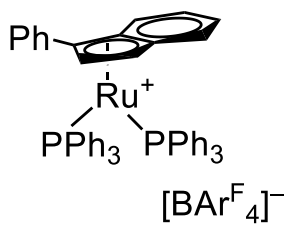

Ru-4

\section{Bis-TMS protected (Z)-but-2-ene-1,4-diol (S1)}

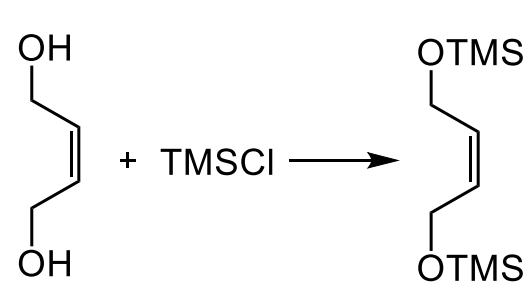

s1 Under inert atmosphere, TMSCl (4 equiv $194.31 \mathrm{mmol}$, $24.5 \mathrm{~mL}$ ) was slowly added to a stirred solution of (Z)but-2-ene-1,4-diol (1.0 equiv, $48.6 \mathrm{mmol}, 4.0 \mathrm{~mL}$ ) and triethylamine ( 6.0 equiv, $291 \mathrm{mmol}, 40.4 \mathrm{~mL}$ ) in dry DCM $(100 \mathrm{~mL})$ kept at $0{ }^{\circ} \mathrm{C}$. The reaction mixture was

allowed to warm to room temperature and then stir for an additional $4 \mathrm{~h}$. The reaction was quenched by adding a saturated aqueous solution of $\mathrm{NaHCO}_{3}(100 \mathrm{~mL})$. The organic layer was washed with $\mathrm{NaHCO}_{3 \text { (sat.) }}(2 \times 100 \mathrm{~mL})$ and brine $(1 \times 100 \mathrm{~mL})$. The organic phase 
was separated and dried over anhydrous $\mathrm{Na}_{2} \mathrm{SO}_{4}$. The solid was filtered off and the volatiles from the filtrate were evaporated under reduced pressure. The residue was subjected to flash column chromatography on silica, with petroleum ether $(2 \times 500 \mathrm{~mL})$ and a mixture of petroleum ether and ethyl acetate $(95: 5,3 \times 500 \mathrm{~mL})$ as the eluent. Fractions containing the pure product were combined, and the solvent was removed under reduced pressure, yielding the product $(9.5 \mathrm{~g}, 40.9 \mathrm{mmol}, 84 \%)$ as a colorless liquid. The NMR data match previously reported data for the title product. ${ }^{6}$

${ }^{1} \mathbf{H}$ NMR $\left(500 \mathrm{MHz}, \mathrm{CDCl}_{3}\right) \delta 5.63-5.55(\mathrm{~m}, 2 \mathrm{H}), 4.24-4.16(\mathrm{~m}, 4 \mathrm{H}), 0.13(\mathrm{~s}, 18 \mathrm{H})$.

\section{(R,E)-3-(4-methylcyclohex-3-en-1-yl)but-2-en-1-yl acetate (S2)}

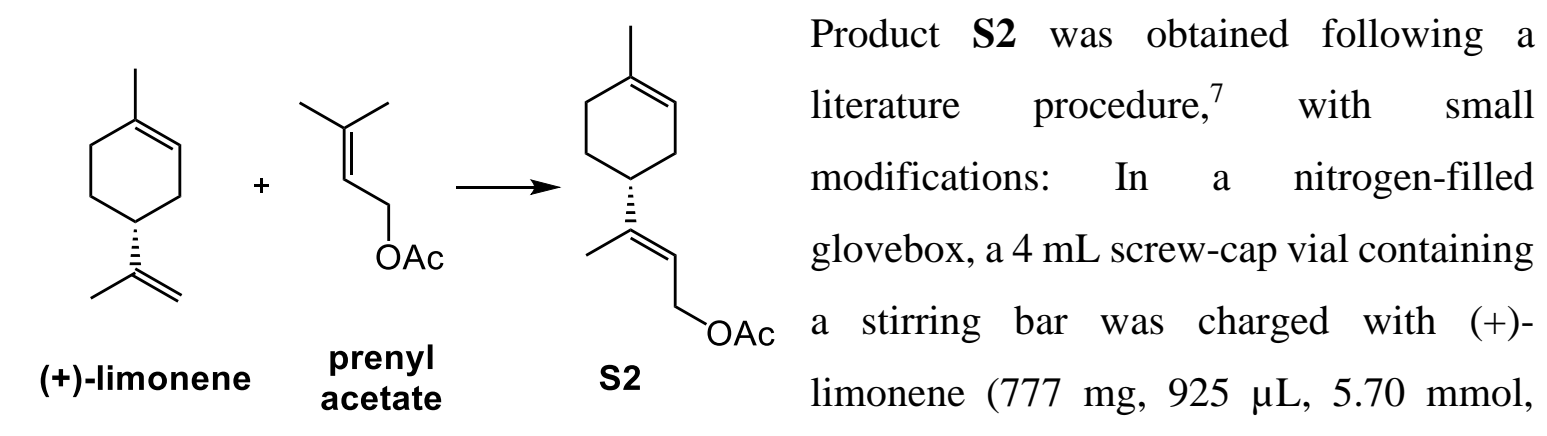

30.0 equiv), prenyl acetate $\left(24.3 \mathrm{mg}, 26.5 \mu \mathrm{L}, 0.19 \mathrm{mmol}, 1.0\right.$ equiv), $2^{\text {nd }}$ gen. HoveydaGrubbs catalyst $(6.0 \mathrm{mg}, 0.010 \mathrm{mmol}, 0.05$ equiv), and benzene $(1 \mathrm{~mL})$. The vial was sealed with a Teflon-lined screw cap, removed from the glovebox, placed in a preheated aluminum block at $100{ }^{\circ} \mathrm{C}$, and allowed to stir for $24 \mathrm{~h}$. The volatiles from the mixture were removed under reduced pressure. The residue was subjected to column chromatography on silica gel, with a mixture of petroleum ether and ethyl acetate as the eluent. Fractions containing the pure product were combined (judged by TLC and GC-MS analysis), the solvent was evaporated, and the residue was used directly in the following step. 


\section{(R,E)-3-(4-methylcyclohex-3-en-1-yl)but-2-en-1-ol (8d)}

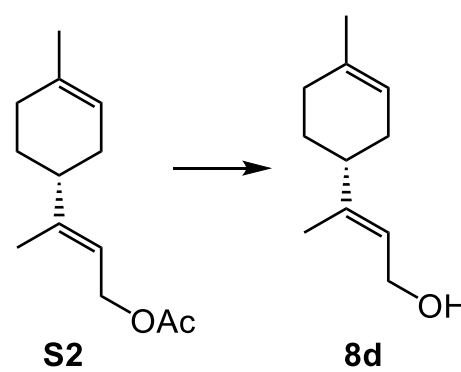

To the above-described material containing $\mathbf{S 2}, \mathrm{K}_{2} \mathrm{CO}_{3}(26.5$ $\mathrm{mg})$, and dry $\mathrm{MeOH}(1 \mathrm{~mL})$ were added. The reaction mixture was allowed to stir at $50^{\circ} \mathrm{C}$ for $16 \mathrm{~h}$ (when GC-MS analysis indicated full conversion of the starting material).

The volatiles were removed under reduced pressure. The residue was subjected to column chromatography on silica gel, with a mixture of petroleum ether and ethyl acetate as the eluent. Fractions containing the pure product (judged by TLC analysis) were combined, and the solvent was evaporated, yielding product $8 \mathbf{d}$ (ca. 14\% yield over 2 steps) as light-yellow oil. The NMR data match previously reported data for the title product. $^{8}$

${ }^{1} \mathbf{H}$ NMR (400 MHz, $\left.\mathrm{CDCl}_{3}\right): \delta 5.50-5.15(\mathrm{~m}, 2 \mathrm{H}), 4.18(\mathrm{~d}, \mathrm{~J}=6.8 \mathrm{~Hz}, 1 \mathrm{H}), 2.16-1.84$ (m, 5H), $1.75(\mathrm{~m}, 1 \mathrm{H}), 1.66(\mathrm{~s}, 3 \mathrm{H}), 1.65(\mathrm{~s}, 3 \mathrm{H}), 1.49$ (m, 1H), $1.39-1.28$ (br s, 1H). 


\section{ONE-POT ISOMERIZATION AND ENANTIOSELECTIVE ARYLATION OF ALLYLIC ALCOHOLS}

\section{A. General Procedures}

General procedure 1: enantioselective isomerization-arylation of linear allylic alcohols

In a nitrogen-filled glovebox, an oven-dried $4 \mathrm{~mL}$ screw-cap scintillation vial equipped with an octagonal stir bar $(2 \mathrm{~mm} \times 5 \mathrm{~mm})$ was charged with a stock solution of $[\operatorname{Ir}(\operatorname{cod}) \mathrm{Cl}]_{2}$ (0.21 mg, $1.25 \times 10^{-4}$ equiv, $\left.3.1 \times 10^{-4} \mathrm{mmol}\right)$ in anhydrous toluene $(1 \mathrm{~mL})$. Then, the appropriate allylic alcohol (1.0 equiv, $0.25 \mathrm{mmol}$ ), $\mathrm{K}_{2} \mathrm{CO}_{3}$ (35 mg, 1.0 equiv, $0.25 \mathrm{mmol}$ ), and degassed $\mathrm{H}_{2} \mathrm{O}(150 \mu \mathrm{L})$ were added. Next, the vial was sealed with a Teflon-lined screw cap, placed in a preheated aluminum block at $30^{\circ} \mathrm{C}$, and allowed to stir at $800 \mathrm{rpm}$ for $2 \mathrm{~h}$. After that, the vial was removed from the heating block and let to cool to room temperature. (In the meantime, a stock solution of Ru-1 was prepared by allowing to stir a mixture of $\left[\mathrm{Ru}(\mathrm{p} \text {-cymene }) \mathrm{Cl}_{2}\right]_{2}\left(4.6 \mathrm{mg}, 0.030\right.$ equiv, $\left.7.5 \times 10^{-3} \mathrm{mmol}\right)$ and Me-BIPAM (13 mg, 0.066 equiv, $1.65 \times 10^{-2} \mathrm{mmol}$ ) in toluene $(1 \mathrm{~mL})$ for $1 \mathrm{~h}$ at $\left.\mathrm{rt}\right)$. Then, the solution of Ru-1 and arylboronic acid (3.0 equiv, $0.75 \mathrm{mmol}$ ) were added to the reaction mixture. The vial was re-sealed with a Teflon-lined screw cap, removed from the glovebox, placed in a preheated aluminum block at $60{ }^{\circ} \mathrm{C}$, and allowed to stir at $800 \mathrm{rpm}$ for $6 \mathrm{~h}$. Next, the vial was removed from the heating block and let to cool to room temperature. (The yield was measured by GC-MS and/or NMR analysis using dodecane or 1,3,5trimethoxybenezene as an internal standards). The volatiles were removed under reduced pressure. The residue was subjected to column chromatography on silica gel (12 g), conducted with the aid of a Combiflash instrument, using a mixture of petroleum ether and ethyl acetate (usually with gradient of 100:0 - 80:20) as the eluent. Fractions containing the pure product (judged by the TLC and/or GC analyses) were combined, and the solvent was evaporated, yielding the target product. 


\section{General procedure 2: enantioselective isomerization-arylation of linear alcohols}

\section{bearing a remote double bond}

In a nitrogen-filled glovebox, an oven-dried $4 \mathrm{~mL}$ screw-cap scintillation vial equipped with an octagonal stir bar $(2 \mathrm{~mm}$ x $5 \mathrm{~mm}$ ) was charged with a solution of Alkene Zipper catalyst Ru-2 (acetonitrile(cyclopentadienyl)[2-(di-i-propylphosphino)-4-( $t$-butyl)-1methyl-1H-imidazole]ruthenium(II) hexafluorophosphate; $3.0 \mathrm{mg}, 0.020$ equiv, $5.0 \times 10^{-3}$ mmol) in anhydrous dichloromethane $(1 \mathrm{~mL})$. The appropriate allylic alcohol (1.0 equiv, $0.25 \mathrm{mmol}$ ) was added. Next, the vial was sealed with a Teflon-lined screw cap, placed in a preheated aluminum block at $70{ }^{\circ} \mathrm{C}$, and allowed to stir at $800 \mathrm{rpm}$ for $3 \mathrm{~h}$. After that, the vial was removed from the heating block and let to cool to room temperature. (In the meantime, a stock solution of Ru-1 was prepared by allowing to stir a mixture of $[\mathrm{Ru}(\mathrm{p}-$ cymene) $\left.\mathrm{Cl}_{2}\right]_{2}\left(4.6 \mathrm{mg}, 0.030\right.$ equiv, $7.5 \times 10^{-3} \mathrm{mmol}$ ) and Me-BIPAM (13 mg, 0.066 equiv, $1.65 \times 10^{-2} \mathrm{mmol}$ ) in toluene ( $1 \mathrm{~mL}$ ) for $1 \mathrm{~h}$ at $\mathrm{rt}$ ). Then, the solution of $\mathbf{R u}-\mathbf{1}$, arylboronic acid (3.0 equiv, $0.75 \mathrm{mmol}$ ), and $\mathrm{K}_{2} \mathrm{CO}_{3}$ (35 mg, 1 equiv) were added to the reaction mixture. The vial was re-sealed with a Teflon-lined screw cap, removed from the glovebox, placed in a preheated aluminum block at $60{ }^{\circ} \mathrm{C}$, and allowed to stir at $800 \mathrm{rpm}$ for $6 \mathrm{~h}$. Next, the vial was removed from the heating block, let to cool to room temperature. (The yield was measured by GC-MS and/or NMR analysis using dodecane or 1,3,5trimethoxybenezene as an internal standards). The volatiles were removed under reduced pressure. The residue was subjected to column chromatography on silica gel (12 g), conducted with the aid of a Combiflash instrument, using a mixture of petroleum ether and ethyl acetate (usually with gradient of 100:0 - 80:20) as the eluent. Fractions containing the pure product (judged by the TLC and/or GC analyses) were combined, and the solvent was evaporated, yielding the target product. 


\section{B. Full Characterization of Reaction Products}

\section{(R)-1-phenylhexan-1-ol (3aa)}

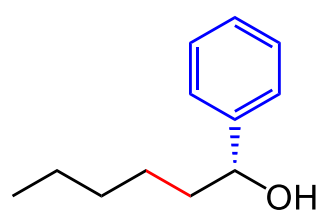

The compound 3aa was prepared according to General procedure 1 with $(\mathrm{R}, \mathrm{R})-\mathbf{R u}-1$ by reaction of $(E)$-hex-2-en-1-ol $(29 \mu \mathrm{L}, 0.25$ $\mathrm{mmol})$ with phenylboronic acid (91 $\mathrm{mg}, 0.75 \mathrm{mmol})$ and was isolated by column chromatography (silica gel, petroleum ether to petroleum ether/ethyl acetate 85:15) to give a colorless oil in 78\% yield (34.6 mg); NMR yield $81 \%$. ${ }^{1} \mathbf{H}$ NMR $\left(500 \mathrm{MHz}, \mathrm{CDCl}_{3}\right) \delta 7.34(\mathrm{~d}, J=3.7 \mathrm{~Hz}, 4 \mathrm{H}), 7.29-7.24(\mathrm{~m}, 1 \mathrm{H}), 4.65$ (t, $J=$ $6.8 \mathrm{~Hz}, 1 \mathrm{H}), 1.88$ (d, $J=2.1 \mathrm{~Hz}, 1 \mathrm{H}), 1.84-1.75$ (m, 1H), $1.74-1.65$ (m, 1H), $1.46-1.36$ $(\mathrm{m}, 1 \mathrm{H}), 1.34-1.22(\mathrm{~m}, 5 \mathrm{H}), 0.92-0.82(\mathrm{~m}, 3 \mathrm{H})$.

${ }^{13} \mathbf{C}\left\{{ }^{1} \mathbf{H}\right\}$ NMR $\left(126 \mathrm{MHz}, \mathrm{CDCl}_{3}\right) \delta 145.1,128.5,127.6,126.0,74.8,39.2,31.9,25.6,22.7$, 14.2.HRMS (ESI) m/z: [M+H-H $\left.{ }_{2} \mathrm{O}\right]^{+}$Calcd for $\mathrm{C}_{12} \mathrm{H}_{17}$ 161.1325; Found 161.1326.

SFC with Chiralpak IG-3, 3\% iPrOH / 97\% $\mathrm{CO}_{2}, 1.2 \mathrm{~mL} / \mathrm{min}, \mathrm{t}($ minor, $(\mathbf{S})-3 \mathbf{a a})=3.66$ $\min , \mathrm{t}($ major, $(\mathbf{R})-3 \mathbf{a a})=4.00 \mathrm{~min}$.

Specific rotation: $[\alpha]_{\mathrm{D}}{ }^{20}+31.6^{\circ}\left(\mathrm{c} 1.00, \mathrm{CHCl}_{3}\right)$ for an enantiomerically enriched sample of $96: 4$ er. The absolute configuration was determined by comparison of the optical rotation with that reported in literature $[\alpha]_{\mathrm{D}}^{23}+37.5^{\circ}\left(\mathrm{c} 0.82, \mathrm{CHCl}_{3}\right), 97: 3$ er. $^{9}$

\section{(R)-1-(4-methoxyphenyl)hexan-1-ol (3ab)}

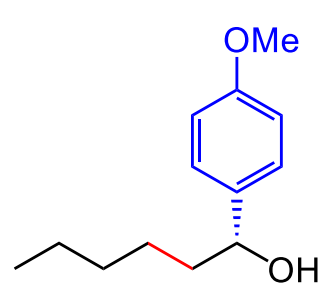

The compound 3ab was prepared according to General procedure 1 with (R,R)-Ru-1) by reaction of (E)-hex-2-en-1-ol $(29 \mu \mathrm{L}, 0.25$ mmol) with (4-methoxyphenyl)boronic acid (114.0 mg, $0.75 \mathrm{mmol}$ ) and was isolated by column chromatography (silica gel, petroleum ether to petroleum ether/ethyl acetate $85: 15$ ) to give a white solid, mp [43.2 $-43.7^{\circ} \mathrm{C}$ ], in $81 \%$ yield $(42.0 \mathrm{mg})$; NMR yield $92 \%$.

${ }^{1} \mathbf{H}$ NMR $\left(500 \mathrm{MHz}, \mathrm{CDCl}_{3}\right) \delta 7.30-7.22(\mathrm{~m}, 2 \mathrm{H}), 6.92-6.83(\mathrm{~m}, 2 \mathrm{H}), 4.60(\mathrm{t}, J=6.7$ $\mathrm{Hz}, 1 \mathrm{H}), 3.80$ (s, 3H), 1.83 (s, 1H), $1.82-1.75$ (m, 1H), $1.73-1.62$ (m, 1H), $1.43-1.34$ (m, 1H), $1.33-1.20(\mathrm{~m}, 5 \mathrm{H}), 0.91-0.83(\mathrm{~m}, 3 \mathrm{H})$.

${ }^{13} \mathbf{C}\left\{{ }^{1} \mathbf{H}\right\}$ NMR $\left(126 \mathrm{MHz}, \mathrm{CDCl}_{3}\right) \delta 159.1,137.2,127.3,113.9,74.4,55.4,39.1,31.9,25.7$, $22.7,14.2$.

HRMS (ESI) m/z: [M+H-H $\left.\mathrm{H}_{2}\right]^{+}$Calcd for $\mathrm{C}_{13} \mathrm{H}_{19} \mathrm{O}$ 191.1430; Found 191.1432. 
SFC with Chiralpak IC-3, 5\% iPrOH / 95\% $\mathrm{CO}_{2}, 1.2 \mathrm{~mL} / \mathrm{min}, \mathrm{t}($ major, $(\mathbf{R})-3 a b)=4.38$ $\min , \mathrm{t}(\operatorname{minor},(\mathbf{S})-3 \mathbf{a b})=5.00 \mathrm{~min}$.

Specific rotation: $[\alpha]_{\mathrm{D}}{ }^{20}+27.5^{\circ}\left(\mathrm{c} 1.00, \mathrm{CHCl}_{3}\right)$ for an enantiomerically enriched sample of $96: 4$ er. The absolute configuration was determined by comparison of the optical rotation with that reported in literature $[\alpha]_{\mathrm{D}}{ }^{28}+18.8^{\circ}\left(\mathrm{c} 1.02, \mathrm{CHCl}_{3}\right), 98.5: 1.5 \mathrm{er}^{10}$

\section{(R)-1-(p-tolyl)hexan-1-ol (3ac)}

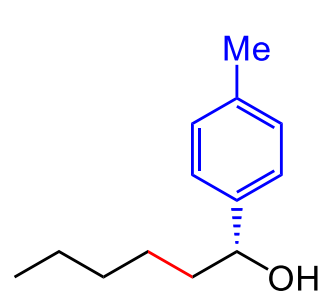

The compound 3ac was prepared according to General procedure 1 with (R,R)-Ru-1 by reaction of (E)-hex-2-en-1-ol (29 $\mu \mathrm{L}, 0.25$ mmol) with $p$-tolylboronic acid $(102.0 \mathrm{mg}, 0.75 \mathrm{mmol})$ and was isolated by column chromatography (silica gel, petroleum ether to petroleum ether/ethyl acetate 85:15) to give a white crystals, mp [47.8 $\left.-48.2^{\circ} \mathrm{C}\right]$, in $83 \%$ yield $(40.0 \mathrm{mg})$; NMR yield $87 \%$.

${ }^{1} \mathbf{H}$ NMR $\left(500 \mathrm{MHz}, \mathrm{CDCl}_{3}\right) \delta 7.23(\mathrm{~d}, \mathrm{~J}=8.0 \mathrm{~Hz}, 2 \mathrm{H}), 7.16(\mathrm{~d}, \mathrm{~J}=7.9 \mathrm{~Hz}, 2 \mathrm{H}), 4.62(\mathrm{t}, \mathrm{J}$ $=6.7 \mathrm{~Hz}, 1 \mathrm{H}), 2.35(\mathrm{~s}, 3 \mathrm{H}), 1.88(\mathrm{~s}, 1 \mathrm{H}), 1.84-1.74(\mathrm{~m}, 1 \mathrm{H}), 1.74-1.63(\mathrm{~m}, 1 \mathrm{H}), 1.47-$ $1.35(\mathrm{~m}, 1 \mathrm{H}), 1.35-1.20(\mathrm{~m}, 5 \mathrm{H}), 0.94-0.82(\mathrm{~m}, 3 \mathrm{H})$.

${ }^{13} \mathbf{C}\left\{{ }^{1} \mathbf{H}\right\}$ NMR $\left(126 \mathrm{MHz}, \mathrm{CDCl}_{3}\right) \delta 142.1,137.2,129.2,126.0,74.7,39.1,31.9,25.7,22.7$, 21.2, 14.2 .

HRMS (ESI) m/z: [M+H-H $\left.\mathrm{H}_{2}\right]^{+}$Calcd for $\mathrm{C}_{13} \mathrm{H}_{19}$ 175.1481; Found 175.1482.

SFC with Chiralpak IB N-3, 2.5\% iPrOH / 97.5\% $\mathrm{CO}_{2}, 1.2 \mathrm{~mL} / \mathrm{min}, \mathrm{t}$ (minor, (S)-3ac) $=$ $3.21 \mathrm{~min}, \mathrm{t}($ major, $(\mathbf{R})-3 a c)=3.46 \min$.

Specific rotation: $[\alpha]_{\mathrm{D}}{ }^{20}+28.6^{\circ}\left(\mathrm{c} 1.02, \mathrm{CHCl}_{3}\right)$ for an enantiomerically enriched sample of $97: 3$ er. The absolute configuration was assigned by analogy to (R)-3aa and it was not further verified.

\section{(R)-1-(4-isopropylphenyl)hexan-1-ol (3ad)}

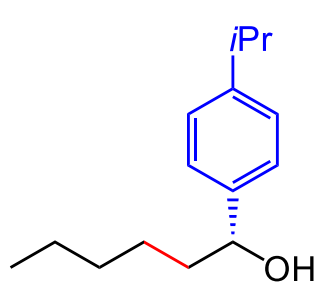

The compound 3ad was prepared according to General procedure 1 with (R,R)-Ru-1 by reaction of (E)-hex-2-en-1-ol $(29 \mu \mathrm{L}, 0.25$ $\mathrm{mmol}$ ) with (4-isopropylphenyl)boronic acid (123.0 $\mathrm{mg}, 0.75 \mathrm{mmol}$ ) and was isolated by column chromatography (silica gel, petroleum 
ether to petroleum ether/ethyl acetate $85: 15)$ to give a colorless oil in $77 \%$ yield $(42.2 \mathrm{mg})$; NMR yield $80 \%$.

${ }^{1} \mathbf{H}$ NMR $\left(500 \mathrm{MHz}, \mathrm{CDCl}_{3}\right) \delta 7.27(\mathrm{~d}, \mathrm{~J}=8.2 \mathrm{~Hz}, 2 \mathrm{H}), 7.21(\mathrm{~d}, \mathrm{~J}=8.2 \mathrm{~Hz}, 2 \mathrm{H}), 4.63(\mathrm{t}, \mathrm{J}$ $=6.6 \mathrm{~Hz}, 1 \mathrm{H}), 2.91($ hept $, \mathrm{J}=7.0 \mathrm{~Hz}, 1 \mathrm{H}), 1.87-1.75(\mathrm{~m}, 2 \mathrm{H}), 1.74-1.64(\mathrm{~m}, 1 \mathrm{H}), 1.49$ $-1.39(\mathrm{~m}, 1 \mathrm{H}), 1.35-1.27(\mathrm{~m}, 5 \mathrm{H}), 1.25(\mathrm{~d}, \mathrm{~J}=7.0 \mathrm{~Hz}, 6 \mathrm{H}), 0.92-0.83(\mathrm{~m}, 3 \mathrm{H})$.

${ }^{13} \mathbf{C}\left\{{ }^{1} \mathbf{H}\right\}$ NMR $\left(126 \mathrm{MHz}, \mathrm{CDCl}_{3}\right) \delta$ 148.3, 142.5, 126.6, 126.0, 74.7, 39.1, 33.9, 31.9, 25.8, 24.2, 22.7, 14.2.

HRMS (ESI) m/z: [M+H-H $\left.\mathrm{H}_{2} \mathrm{O}\right]^{+}$Calcd for $\mathrm{C}_{15} \mathrm{H}_{23}$ 203.1794; Found 203.1793.

SFC with Chiralpak IB N-3, 5\% iPrOH / 95\% CO $\mathrm{CO}_{2}, 1.2 \mathrm{~mL} / \mathrm{min}, \mathrm{t}(\operatorname{minor},(\mathbf{S})-3 \mathrm{ad})=1.96$ $\min , \mathrm{t}($ major, $(\mathbf{R})-\mathbf{3 a d})=2.17 \mathrm{~min}$.

Specific rotation: $[\alpha]_{\mathrm{D}}{ }^{20}+26.0^{\circ}\left(\mathrm{c} 1.00, \mathrm{CHCl}_{3}\right.$ ) for an enantiomerically enriched sample of $96: 4$ er. The absolute configuration was assigned by analogy to (R)-3aa and it was not further verified.

\section{(R)-1-(4-(methylthio)phenyl)hexan-1-ol (3ae)}

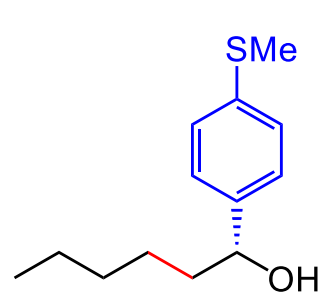

The compound 3ae was prepared according to General procedure 1 with (R,R)-Ru-1 by reaction of (E)-hex-2-en-1-ol (29 $\mu \mathrm{L}, 0.25$ mmol) with (4-(methylthio)phenyl)boronic acid (126.0 mg, 0.75 $\mathrm{mmol}$ ) and was isolated by column chromatography (silica gel, petroleum ether to petroleum ether/ethyl acetate 85:15) to give a white solid, $\mathrm{mp}$ [64.1 $-64.7{ }^{\circ} \mathrm{C}$ ], in $73 \%$ yield (41.1 mg); NMR yield $83 \%$.

${ }^{1} \mathbf{H}$ NMR $\left(500 \mathrm{MHz}, \mathrm{CDCl}_{3}\right) \delta 7.29-7.21(\mathrm{~m}, 4 \mathrm{H}), 4.62(\mathrm{dd}, \mathrm{J}=7.5,5.9 \mathrm{~Hz}, 1 \mathrm{H}), 2.48(\mathrm{~s}$, $3 \mathrm{H}), 1.81(\mathrm{~s}, 1 \mathrm{H}), 1.80-1.73(\mathrm{~m}, 1 \mathrm{H}), 1.71-1.63(\mathrm{~m}, 1 \mathrm{H}), 1.45-1.34(\mathrm{~m}, 1 \mathrm{H}), 1.34-$ $1.22(\mathrm{~m}, 5 \mathrm{H}), 0.92-0.82(\mathrm{~m}, 3 \mathrm{H})$.

${ }^{13} \mathbf{C}\left\{{ }^{1} \mathbf{H}\right\}$ NMR $\left(126 \mathrm{MHz}, \mathrm{CDCl}_{3}\right) \delta 142.0,137.5,126.9,126.6,74.4,39.1,31.8,25.6,22.7$, 16.1, 14.2.

HRMS (ESI) m/z: [M+H-H $\left.\mathrm{H}_{2} \mathrm{O}\right]^{+}$Calcd for $\mathrm{C}_{13} \mathrm{H}_{19} \mathrm{~S}$ 207.1202; Found 207.1208.

SFC with Chiralpak IG-3, 5\% iPrOH / 95\% CO $2,1.2 \mathrm{~mL} / \mathrm{min}, \mathrm{t}($ minor, (S)-3ae) $=7.52$ min, $\mathrm{t}($ major, $(\mathbf{R})-3 \mathbf{a e})=8.24 \mathrm{~min}$. 
Specific rotation: $[\alpha]_{\mathrm{D}}^{20}+26.9^{\circ}$ (c 1.01, $\mathrm{CHCl}_{3}$ ) for an enantiomerically enriched sample of $95: 5$ er. The absolute configuration was assigned by analogy to (R)-3ab and it was not further verified.

\section{(R)-1-([1,1'-biphenyl]-4-yl)hexan-1-ol (3af)}

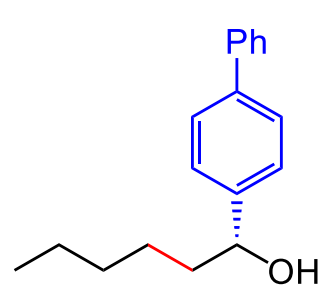

The compound 3af was prepared according to General procedure 1 with (R,R)-Ru-1) by reaction of (E)-hex-2-en-1-ol (29 $\mu \mathrm{L}, 0.25$ mmol) with [1,1'-biphenyl]-4-ylboronic acid (148.5 mg, $0.75 \mathrm{mmol})$ and was isolated by column chromatography (silica gel, petroleum ether to petroleum ether/ethyl acetate 85:15) to give a transparent oil in $55 \%$ yield $\left(34.8 \mathrm{mg}\right.$ ); NMR yield $54 \%$ or $72 \%$ if the $2^{\text {nd }}$ step is performed at $90{ }^{\circ} \mathrm{C}$ for 24 hours.

${ }^{1} \mathbf{H}$ NMR $\left(500 \mathrm{MHz}, \mathrm{CDCl}_{3}\right) \delta 7.64-7.55(\mathrm{~m}, 4 \mathrm{H}), 7.49-7.39(\mathrm{~m}, 4 \mathrm{H}), 7.38-7.33(\mathrm{~m}$, $1 \mathrm{H}), 4.72(\mathrm{t}, J=6.7 \mathrm{~Hz}, 1 \mathrm{H}), 1.87(\mathrm{~s}, 1 \mathrm{H}), 1.86-1.80(\mathrm{~m}, 1 \mathrm{H}), 1.79-1.71(\mathrm{~m}, 1 \mathrm{H}), 1.51$ $-1.40(\mathrm{~m}, 1 \mathrm{H}), 1.37-1.28(\mathrm{~m}, 5 \mathrm{H}), 0.94-0.84(\mathrm{~m}, 3 \mathrm{H})$.

${ }^{13} \mathbf{C}\left\{{ }^{1} \mathbf{H}\right\}$ NMR $\left(126 \mathrm{MHz}, \mathrm{CDCl}_{3}\right) \delta 144.1,141.0,140.5,128.9,127.4,127.3,127.2,126.5$, 74.6, 39.2, 31.9, 25.7, 22.7, 14.2.

HRMS (ESI) m/z: [M+H-H $\left.\mathrm{H}_{2} \mathrm{O}\right]^{+}$Calcd for $\mathrm{C}_{18} \mathrm{H}_{21}$ 237.1638; Found 237.1638.

SFC with Chiralpak IG-3, 10\% iPrOH / 90\% CO $\mathrm{CO}_{2}, 1.2 \mathrm{~mL} / \mathrm{min}$, $\mathrm{t}($ minor, $(\mathbf{S})-\mathbf{3 a f})=4.71$ $\min , \mathrm{t}($ major, $(\mathbf{R})-\mathbf{3 a f})=5.69 \mathrm{~min}$.

Specific rotation: $[\alpha]_{\mathrm{D}}^{20}+23.4^{\circ}$ (c $0.94, \mathrm{CHCl}_{3}$ ) for an enantiomerically enriched sample of $95: 5$ er. The absolute configuration was assigned by analogy to (R)-3aa and it was not further verified.

\section{(R)-1-(4-fluorophenyl)hexan-1-ol (3ag)}

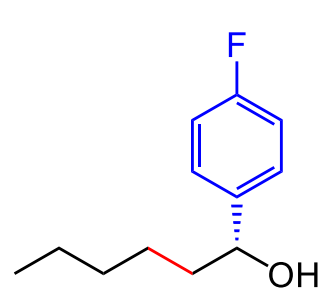

The compound 3ag was prepared according to General procedure 1 with $(\mathrm{R}, \mathrm{R})-\mathbf{R u}-1$ by reaction of (E)-hex-2-en-1-ol (29 $\mu \mathrm{L}, 0.25$ $\mathrm{mmol}$ ) with (4-fluorophenyl)boronic acid (104.9 mg, $0.75 \mathrm{mmol}$ ) and was isolated by column chromatography (silica gel, petroleum ether to petroleum ether/ethyl acetate $85: 15$ ) to give a white solid, mp [42.8

$-43.5^{\circ} \mathrm{C}$ ], in $86 \%$ yield $(42.1 \mathrm{mg})$; NMR yield $93 \%$. 
${ }^{1}$ H NMR $\left(500 \mathrm{MHz}, \mathrm{CDCl}_{3}\right) \delta 7.34-7.27(\mathrm{~m}, 2 \mathrm{H}), 7.06$ - $6.98(\mathrm{~m}, 2 \mathrm{H}), 4.64(\mathrm{dd}, \mathrm{J}=7.6$, $5.8 \mathrm{~Hz}, 1 \mathrm{H}), 1.93(\mathrm{~s}, 1 \mathrm{H}), 1.81-1.72(\mathrm{~m}, 1 \mathrm{H}), 1.71-1.61(\mathrm{~m}, 1 \mathrm{H}), 1.44-1.34(\mathrm{~m}, 1 \mathrm{H})$, $1.34-1.20(\mathrm{~m}, 5 \mathrm{H}), 0.92-0.82(\mathrm{~m}, 3 \mathrm{H})$.

${ }^{13} \mathbf{C}\left\{{ }^{1} \mathbf{H}\right\}$ NMR $\left(126 \mathrm{MHz}, \mathrm{CDCl}_{3}\right) \delta 162.3(\mathrm{~d}, \mathrm{~J}=245.2 \mathrm{~Hz}), 140.8(\mathrm{~d}, \mathrm{~J}=3.1 \mathrm{~Hz}), 127.6$ $(\mathrm{d}, \mathrm{J}=8.0 \mathrm{~Hz}), 115.4,115.2,74.2(\mathrm{~d}, \mathrm{~J}=0.6 \mathrm{~Hz}), 39.30(\mathrm{~d}, \mathrm{~J}=0.8 \mathrm{~Hz}), 31.8,25.6,22.7$, 14.1.

${ }^{19} \mathbf{F}\left\{{ }^{1} \mathbf{H}\right\}$ NMR $\left(376 \mathrm{MHz}, \mathrm{CDCl}_{3}\right) \delta-115.30$.

HRMS (ESI) m/z: [M+H-H $\left.\mathrm{H}_{2} \mathrm{O}\right]^{+}$Calcd for $\mathrm{C}_{12} \mathrm{H}_{16} \mathrm{~F}$ 179.1231; Found 179.1233.

SFC with Chiralpak IG-3, 5\% iPrOH / 95\% CO $1.2 \mathrm{~mL} / \mathrm{min}, \mathrm{t}($ minor, $(\mathbf{S})-3 \mathbf{a g})=1.75$ $\min , \mathrm{t}($ major, $(\mathbf{R})-3 \mathbf{a g})=1.94 \mathrm{~min}$.

Specific rotation: $[\alpha]_{\mathrm{D}}{ }^{20}+29.3^{\circ}\left(\mathrm{c} 1.03, \mathrm{CHCl}_{3}\right)$ for an enantiomerically enriched sample of $96: 4$ er. The absolute configuration was assigned by analogy to (R)-3aa and it was not further verified.

\section{(R)-1-(4-chlorophenyl)hexan-1-ol (3ah)}

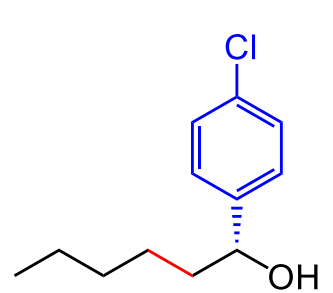

The compound 3ah was prepared according to General procedure 1 with $(\mathrm{R}, \mathrm{R})-\mathbf{R u}-1$ by reaction of (E)-hex-2-en-1-ol $(29 \mu \mathrm{L}, 0.25$ mmol) with (4-chlorophenyl)boronic acid (117.3 $\mathrm{mg}, 0.75 \mathrm{mmol})$ and was isolated by column chromatography (silica gel, petroleum ether to petroleum ether/ethyl acetate $85: 15$ ) to give a white solid, mp [60.5 $-61{ }^{\circ} \mathrm{C}$ ], in $76 \%$ yield $(40.3 \mathrm{mg})$; NMR yield $83 \%$.

${ }^{1} \mathbf{H}$ NMR $\left(500 \mathrm{MHz}, \mathrm{CDCl}_{3}\right) \delta 7.32-7.27(\mathrm{~m}, 2 \mathrm{H}), 7.27-7.23(\mathrm{~m}, 2 \mathrm{H}), 4.63(\mathrm{dd}, \mathrm{J}=7.5$, $5.8 \mathrm{~Hz}, 1 \mathrm{H}), 1.89(\mathrm{~s}, 1 \mathrm{H}), 1.80-1.69(\mathrm{~m}, 1 \mathrm{H}), 1.69-1.60(\mathrm{~m}, 1 \mathrm{H}), 1.42-1.33(\mathrm{~m}, 1 \mathrm{H})$, $1.30-1.22(\mathrm{~m}, 5 \mathrm{H}), 0.90-0.82(\mathrm{~m}, 3 \mathrm{H})$.

${ }^{13} \mathbf{C}\left\{{ }^{1} \mathbf{H}\right\} \mathbf{N M R}\left(126 \mathrm{MHz}, \mathrm{CDCl}_{3}\right) \delta 143.5,133.2,128.7,127.4,74.1,39.3,31.8,25.5,22.7$, 14.1.

HRMS (ESI) m/z: [M+H-H $\left.{ }_{2} \mathrm{O}\right]^{+}$Calcd for $\mathrm{C}_{12} \mathrm{H}_{16} \mathrm{Cl}$ 195.0935; Found 195.0935.

SFC with Chiralpak IC-3, 2.5\% iPrOH / 97.5\% CO $2,1.2 \mathrm{~mL} / \mathrm{min}, \mathrm{t}($ major, $(\mathbf{R})-3 a h)=3.57$ $\min ., \mathrm{t}(\operatorname{minor},(\mathbf{S})-3 \mathrm{ah})=4.04 \mathrm{~min}$. 
Specific rotation: $[\alpha]_{\mathrm{D}}^{20}+26.9^{\circ}$ (c $0.99, \mathrm{CHCl}_{3}$ ) for an enantiomerically enriched sample of $95: 5$ er. The absolute configuration was assigned by analogy to (R)-3aa and it was not further verified.

\section{(R)-1-(4-bromophenyl)hexan-1-ol (3ai)}

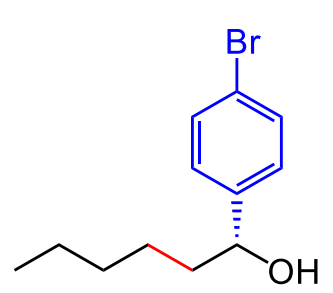

The compound 3ai was prepared according to General procedure 1 with $(\mathrm{R}, \mathrm{R})-\mathbf{R u}-1$ by reaction of (E)-hex-2-en-1-ol (29 $\mu \mathrm{L}, 0.25$ mmol) with (4-bromophenyl)boronic acid (150.6 mg, $0.75 \mathrm{mmol}$ ) and was isolated by column chromatography (silica gel, petroleum ether to petroleum ether/ethyl acetate 85:15) to give a white solid, mp [68.2 $\left.-69.3{ }^{\circ} \mathrm{C}\right]$, in $79 \%$ yield $(50.9 \mathrm{mg})$; NMR yield $83 \%$.

${ }^{1} \mathbf{H}$ NMR $\left(500 \mathrm{MHz}, \mathrm{CDCl}_{3}\right) \delta 7.50-7.42(\mathrm{~m}, 2 \mathrm{H}), 7.25-7.18(\mathrm{~m}, 2 \mathrm{H}), 4.63(\mathrm{dd}, \mathrm{J}=7.5$, $5.8 \mathrm{~Hz}, 1 \mathrm{H}), 1.86(\mathrm{~s}, 1 \mathrm{H}), 1.80-1.70(\mathrm{~m}, 1 \mathrm{H}), 1.71-1.60(\mathrm{~m}, 1 \mathrm{H}), 1.44-1.34(\mathrm{~m}, 1 \mathrm{H})$, $1.32-1.21(\mathrm{~m}, 5 \mathrm{H}), 0.92-0.82(\mathrm{~m}, 3 \mathrm{H})$.

${ }^{13} \mathbf{C}\left\{{ }^{1} \mathbf{H}\right\}$ NMR $\left(126 \mathrm{MHz}, \mathrm{CDCl}_{3}\right) \delta$ 144.0, 131.6, 127.8, 121.3, 74.2, 39.2, 31.8, 25.5, 22.7, 14.1.

HRMS (ESI) m/z: [M+H-H $\left.\mathrm{H}_{2} \mathrm{O}\right]^{+}$Calcd for $\mathrm{C}_{12} \mathrm{H}_{16} \mathrm{Br}$ 239.0430; Found 239.0433.

SFC with Chiralpak IC-3, 5\% iPrOH / 95\% CO $2,1.2 \mathrm{~mL} / \mathrm{min}, \mathrm{t}($ major, (R)-3ai) $=2.46$ min., $\mathrm{t}($ minor, $(\mathbf{S})-\mathbf{3 a i})=2.86 \mathrm{~min}$.

Specific rotation: $[\alpha]_{\mathrm{D}}^{20}+19.7^{\circ}$ (c $0.99, \mathrm{CHCl}_{3}$ ) for an enantiomerically enriched sample of $95: 5$ er. The absolute configuration was assigned by analogy to (R)-3aa and it was not further verified.

\section{(R)-1-(4-(trifluoromethyl)phenyl)hexan-1-ol (3aj)}

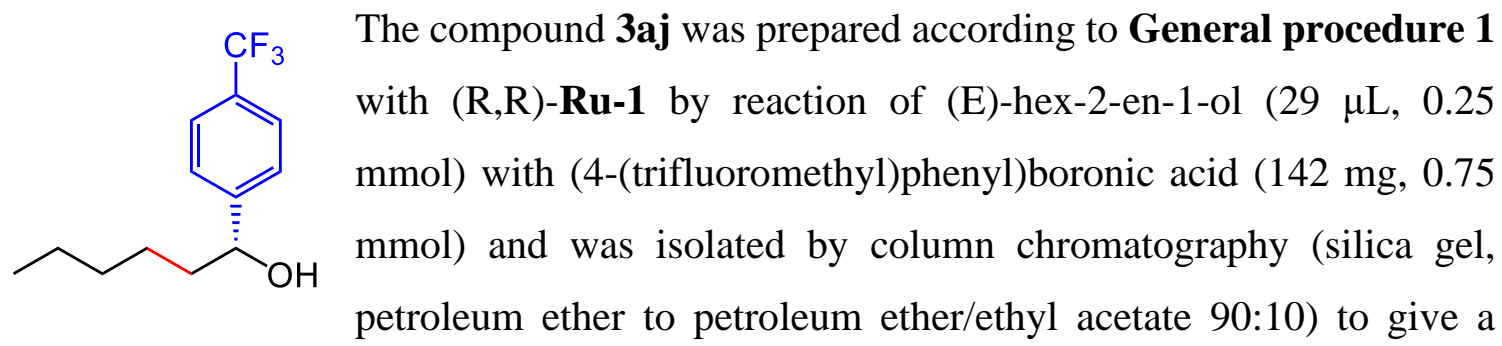
transparent oil in $28 \%$ yield (17 mg), NMR yield $30 \%$. 
${ }^{1} \mathbf{H}$ NMR $\left(500 \mathrm{MHz}, \mathrm{CDCl}_{3}\right) 7.60(\mathrm{~d}, \mathrm{~J}=8.0 \mathrm{~Hz}, 2 \mathrm{H}), 7.45(\mathrm{~d}, \mathrm{~J}=8.0 \mathrm{~Hz}, 2 \mathrm{H}), 4.73(\mathrm{dd}, \mathrm{J}$ $=7.6,5.6 \mathrm{~Hz}, 1 \mathrm{H}), 2.03(\mathrm{~s}, 1 \mathrm{H}), 1.82-1.73(\mathrm{~m}, 1 \mathrm{H}), 1.73-1.64(\mathrm{~m}, 1 \mathrm{H}), 1.46-1.36(\mathrm{~m}$, $1 \mathrm{H}), 1.36-1.23(\mathrm{~m}, 5 \mathrm{H}), 0.92-0.84(\mathrm{~m}, 3 \mathrm{H})$.

${ }^{13} \mathbf{C}\left\{{ }^{1} \mathbf{H}\right\}$ NMR $\left(126 \mathrm{MHz}, \mathrm{CDCl}_{3}\right) \delta 149.0(\mathrm{q}, J=1.3 \mathrm{~Hz}), 129.7(\mathrm{q}, J=32.3 \mathrm{~Hz}), 126.3$, $125.5(\mathrm{q}, J=3.8 \mathrm{~Hz}), 124.3(J=271.5 \mathrm{~Hz}), 74.2,39.4,31.8,25.4,22.7,14.1$.

${ }^{19} \mathbf{F}\left\{{ }^{1} \mathbf{H}\right\}$ NMR $\left(376 \mathrm{MHz}, \mathrm{CDCl}_{3}\right) \delta-62.44$.

HRMS (ESI) m/z: [M+H-H $\left.\mathrm{H}_{2} \mathrm{O}\right]^{+}$Calcd for $\mathrm{C}_{13} \mathrm{H}_{16} \mathrm{~F}_{3}$ 229.1199; Found 229.1196.

SFC with Chiralpak IC-3, 0.5\% THF / 99.5\% $\mathrm{CO}_{2}, 1.2 \mathrm{~mL} / \mathrm{min}, \mathrm{t}($ major, $(\mathbf{R})-3 \mathbf{3 a j})=1.67$ min., $\mathrm{t}($ minor, $(\mathbf{S})-\mathbf{3 a k})=1.84 \mathrm{~min}$.

Specific rotation: $[\alpha]_{\mathrm{D}}^{20}+2.4^{\circ}\left(\mathrm{c} 0.81, \mathrm{CHCl}_{3}\right)$ for an enantiomerically enriched sample of $\sim 60: 40$ er. The absolute configuration was assigned by analogy to (R)-3aa and it was not further verified.

\section{(R)-1-(m-tolyl)hexan-1-ol (3ak)}

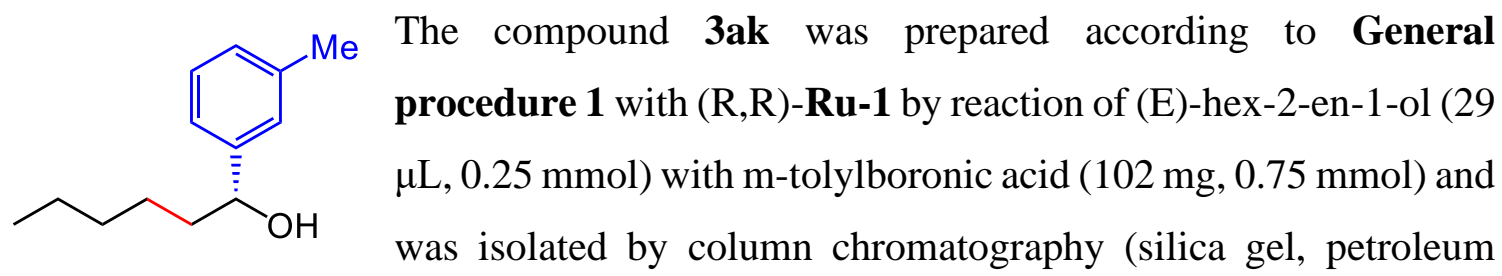

ether to petroleum ether/ethyl acetate 90:10) to give a pale yellow oil in 83\% yield (40 mg), NMR yield $86 \%$.

${ }^{1} \mathbf{H}$ NMR $\left(500 \mathrm{MHz}, \mathrm{CDCl}_{3}\right) \delta 7.30-7.23(\mathrm{~m}, 1 \mathrm{H}), 7.19(\mathrm{~s}, 1 \mathrm{H}), 7.17-7.08(\mathrm{~m}, 2 \mathrm{H}), 4.65$ (dd, $J=7.6,5.8 \mathrm{~Hz}, 1 \mathrm{H}), 2.39$ (s, 3H), $1.90-1.77(\mathrm{~m}, 2 \mathrm{H}), 1.77-1.66(\mathrm{~m}, 1 \mathrm{H}), 1.52-$ $1.40(\mathrm{~m}, 1 \mathrm{H}), 1.37-1.26(\mathrm{~m}, 5 \mathrm{H}), 0.95-0.84(\mathrm{~m}, 3 \mathrm{H})$.

${ }^{13} \mathbf{C}\left\{{ }^{1} \mathbf{H}\right\}$ NMR $\left(126 \mathrm{MHz}, \mathrm{CDCl}_{3}\right) \delta 145.1,138.2,128.4,128.3,126.7,123.1,74.9,39.2$, 31.9, 25.7, 22.7, 21.6, 14.2 .

HRMS (ESI) m/z: [M+H- $\left.\mathrm{H}_{2} \mathrm{O}\right]^{+}$Calcd for $\mathrm{C}_{13} \mathrm{H}_{19}$ 175.1481; Found 175.1486.

SFC with Chiralpak ID-3, 5\% iPrOH / 95\% $\mathrm{CO}_{2}, 1.2 \mathrm{~mL} / \mathrm{min}$, $\mathrm{t}$ (major, $\left.(\mathbf{R})-3 \mathbf{a k}\right)=1.52$ $\min ., \mathrm{t}($ minor, $(\mathbf{S})-\mathbf{3 a k})=1.76 \mathrm{~min}$.

Specific rotation: $[\alpha]_{\mathrm{D}^{20}}+19.6^{\circ}\left(\mathrm{c} 0.32, \mathrm{CHCl}_{3}\right)$ or $[\alpha]_{\mathrm{D}}^{20}+13.4^{\circ}\left(\mathrm{c} 0.32, \mathrm{CH}_{3} \mathrm{OH}\right)$ for an enantiomerically enriched sample of $97: 3$ er. The absolute configuration was determined 
by comparison of the optical rotation measured in $\mathrm{CH}_{3} \mathrm{OH}$ with that reported in literature for the opposite enantiomer $[\alpha]_{\mathrm{D}}^{23}-16.0^{\circ}\left(\mathrm{c} 1.07, \mathrm{CH}_{3} \mathrm{OH}\right), 95: 5 .^{11}$

\section{(R)-1-(3-chlorophenyl)hexan-1-ol (3al)}

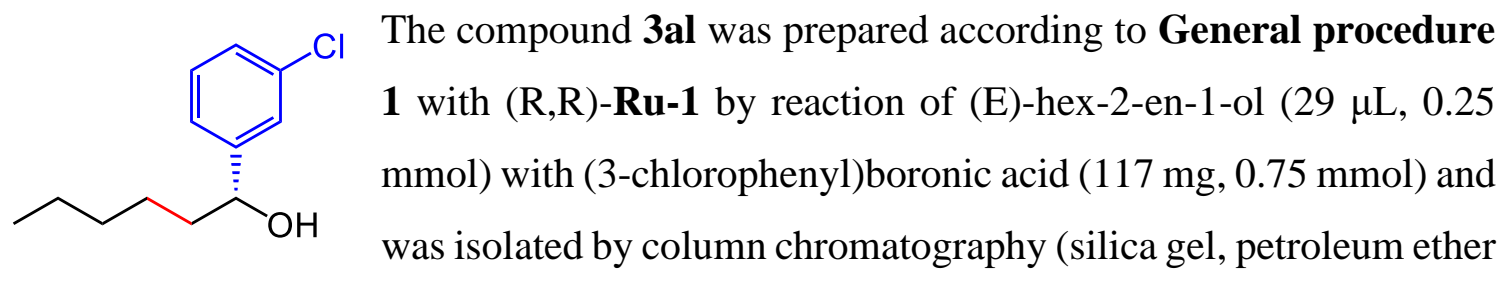
to petroleum ether/ethyl acetate $90: 10)$ to give a transparent oil in $75 \%$ yield (39 $\mathrm{mg})$, NMR yield $79 \%$.

${ }^{1} \mathbf{H}$ NMR $\left(500 \mathrm{MHz}, \mathrm{CDCl}_{3}\right) \delta 7.35(\mathrm{t}, J=1.9 \mathrm{~Hz}, 1 \mathrm{H}), 7.30-7.18(\mathrm{~m}, 3 \mathrm{H}), 4.65(\mathrm{t}, J=$ $6.7 \mathrm{~Hz}, 1 \mathrm{H}), 1.87(\mathrm{~s}, 1 \mathrm{H}), 1.82-1.72(\mathrm{~m}, 1 \mathrm{H}), 1.72-1.64(\mathrm{~m}, 1 \mathrm{H}), 1.46-1.36(\mathrm{~m}, 1 \mathrm{H})$, $1.34-1.24(\mathrm{~m}, 5 \mathrm{H}), 0.92-0.84(\mathrm{~m}, 3 \mathrm{H})$.

${ }^{13} \mathbf{C}\left\{{ }^{1} \mathbf{H}\right\} \mathbf{N M R}\left(126 \mathrm{MHz}, \mathrm{CDCl}_{3}\right) \delta 147.2,134.53,134.49,129.8,127.7,126.2,124.2$, $74.2,39.2,231.8,25.5,22.7,14.2$.

HRMS (ESI) m/z: [M+H-H $\left.\mathrm{H}_{2} \mathrm{O}\right]^{+}$Calcd for $\mathrm{C}_{12} \mathrm{H}_{16} \mathrm{Cl}$ 195.0935; Found 195.0938.

SFC with Chiralpak ID-3, 5\% iPrOH / 95\% CO $1.2 \mathrm{~mL} / \mathrm{min}$, $\mathrm{t}$ (major, $(\mathbf{R})-3 \mathrm{al})=1.69$ min., $\mathrm{t}($ minor, $(\mathbf{S})-\mathbf{3 a l})=1.92 \mathrm{~min}$.

Specific rotation: $[\alpha]_{\mathrm{D}}{ }^{20}+23.0^{\circ}\left(\mathrm{c} 0.43, \mathrm{CHCl}_{3}\right)$ or $[\alpha]_{\mathrm{D}}{ }^{20}+21.5^{\circ}\left(\mathrm{c} 0.43, \mathrm{CH}_{3} \mathrm{OH}\right)$ for an enantiomerically enriched sample of $97: 3$ er. The absolute configuration was determined by comparison of the optical rotation measured in $\mathrm{CH}_{3} \mathrm{OH}$ with that reported in literature for the opposite enantiomer $[\alpha]_{\mathrm{D}}^{23}-25.0^{\circ}\left(\mathrm{c} 1.0, \mathrm{CH}_{3} \mathrm{OH}\right), 78: 22 .{ }^{11}$

\section{(R)-1-(3-bromophenyl)hexan-1-ol (3am)}

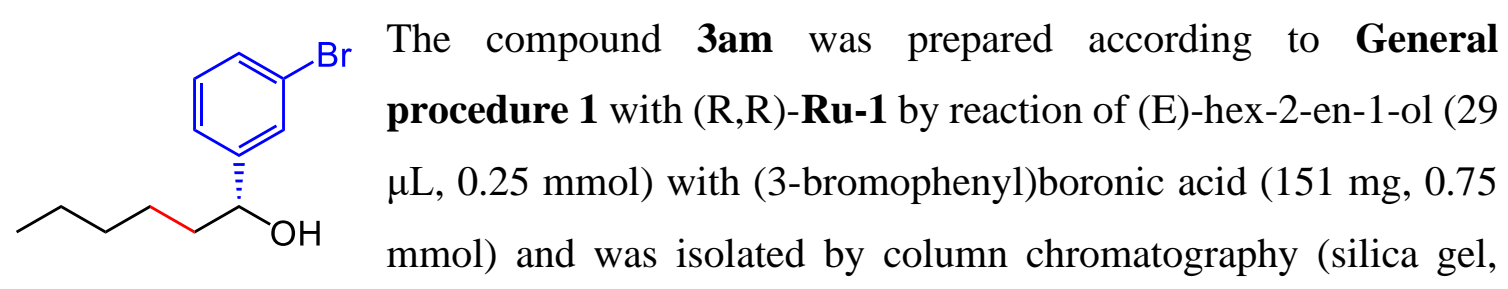

petroleum ether to petroleum ether/ethyl acetate 85:15) to give a yellow oil in $66 \%$ yield (43 mg), NMR yield 74\%. 
${ }^{1} \mathbf{H}$ NMR $\left(500 \mathrm{MHz}, \mathrm{CDCl}_{3}\right) \delta 7.35(\mathrm{t}, J=1.8 \mathrm{~Hz}, 1 \mathrm{H}), 7.30-7.18(\mathrm{~m}, 3 \mathrm{H}), 4.65(\mathrm{dd}, J=$ 7.6, 5.6 Hz, 1H), $1.86(\mathrm{~s}, 1 \mathrm{H}), 1.81-1.73(\mathrm{~m}, 1 \mathrm{H}), 1.73-1.63(\mathrm{~m}, 1 \mathrm{H}), 1.46-1.36(\mathrm{~m}$, $1 \mathrm{H}), 1.34-1.26(\mathrm{~m}, 5 \mathrm{H}), 0.93-0.82(\mathrm{~m}, 3 \mathrm{H})$.

${ }^{13} \mathbf{C}\left\{{ }^{1} \mathbf{H}\right\}$ NMR $\left(126 \mathrm{MHz}, \mathrm{CDCl}_{3}\right) \delta 147.2,134.5,134.5,129.8,127.7,126.2,124.2,74.2$, $39.3,31.8,25.5,22.7,14.2$.

HRMS (ESI) m/z: [M+H-H $\left.\mathrm{H}_{2} \mathrm{O}\right]^{+}$Calcd for $\mathrm{C}_{12} \mathrm{H}_{16} \mathrm{Br}$ 239.0430; Found 239.0435.

SFC with Chiralpak ID-3, 5\% iPrOH / 95\% CO $2,1.2 \mathrm{~mL} / \mathrm{min}$, $\mathrm{t}($ major, $(\mathbf{R})-3 \mathrm{am})=2.04$ min., $\mathrm{t}(\operatorname{minor},(\mathbf{S})-3 \mathbf{a m})=2.50 \mathrm{~min}$.

Specific rotation: $[\alpha]_{\mathrm{D}}^{20}+15.2^{\circ}$ (c 1.04, $\mathrm{CHCl}_{3}$ ) for an enantiomerically enriched sample of $96: 4$ er. The absolute configuration was assigned by analogy to (R)-3ak and it was not further verified.

\section{(R)-1-(3-chloro-4-methoxyphenyl)hexan-1-ol (3an)}

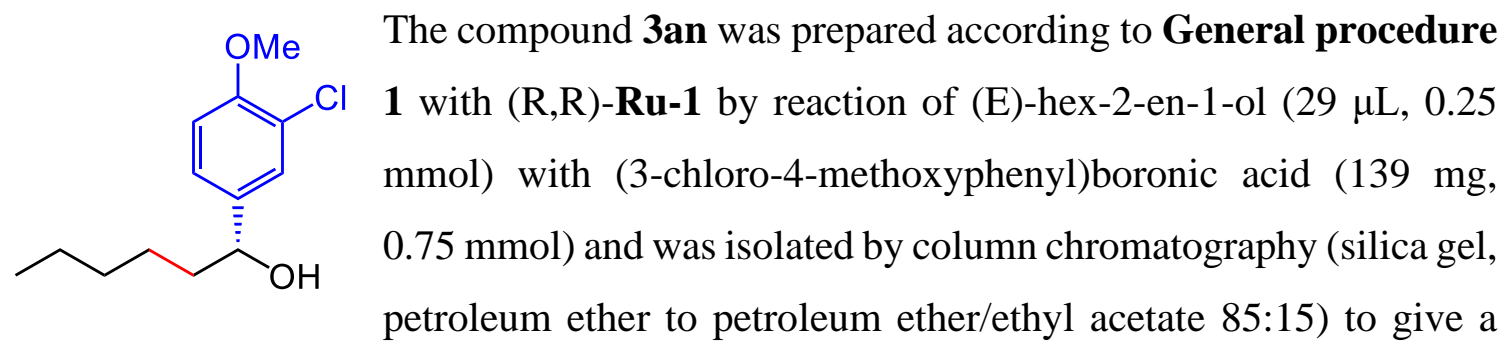
pale yellow oil in $72 \%$ yield ( $45 \mathrm{mg}$ ), NMR yield $77 \%$.

${ }^{1} \mathbf{H}$ NMR $\left(500 \mathrm{MHz}, \mathrm{CDCl}_{3}\right) \delta 7.36(\mathrm{~d}, J=2.2 \mathrm{~Hz}, 1 \mathrm{H}), 7.18(\mathrm{dd}, J=8.4,2.2 \mathrm{~Hz}, 1 \mathrm{H})$, $6.89(\mathrm{~d}, J=8.4 \mathrm{~Hz}, 1 \mathrm{H}), 4.58$ (dd, $J=7.5,5.9 \mathrm{~Hz}, 1 \mathrm{H}), 3.89$ (s, 3H), 1.84 (s, 1H), $1.81-$ $1.71(\mathrm{~m}, 1 \mathrm{H}), 1.70-1.61(\mathrm{~m}, 1 \mathrm{H}), 1.44-1.34(\mathrm{~m}, 1 \mathrm{H}), 1.34-1.20(\mathrm{~m}, 5 \mathrm{H}), 0.91-0.83$ $(\mathrm{m}, 3 \mathrm{H})$.

${ }^{13} \mathbf{C}\left\{{ }^{1} \mathbf{H}\right\}$ NMR $\left(126 \mathrm{MHz}, \mathrm{CDCl}_{3}\right) \delta 154.4,138.3,128.0,125.4,122.5,112.0,73.9,56.3$, $39.1,31.8,25.6,22.7,14.2$.

HRMS (ESI) m/z: [M+H-H $\left.\mathrm{H}_{2} \mathrm{O}\right]^{+}$Calcd for $\mathrm{C}_{13} \mathrm{H}_{18} \mathrm{ClO}$ 225.1041; Found 225.1044.

SFC with Chiralpak IC-3, 10\% iPrOH / 90\% CO $\mathrm{CO}_{2}, 1.2 \mathrm{~mL} / \mathrm{min}, \mathrm{t}($ major, (R)-3an) $=2.78$ min., $\mathrm{t}(\operatorname{minor},(\mathbf{S})-3 a n)=3.20 \mathrm{~min}$.

Specific rotation: $[\alpha]_{\mathrm{D}}^{20}+16.2^{\circ}\left(\mathrm{c} 0.51, \mathrm{CHCl}_{3}\right)$ for an enantiomerically enriched sample of $95: 5$ er. The absolute configuration was assigned by analogy to (R)-3ab and (R)-3ak and it was not further verified. 


\section{(R)-1-(dibenzo[b,d]thiophen-2-yl)hexan-1-ol (3ao)}

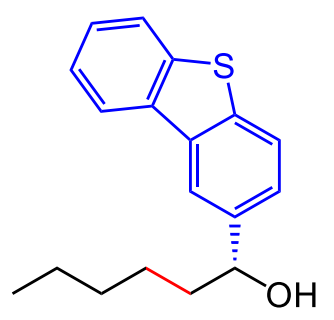

The compound 3ao was prepared according to General procedure 1 with (R,R)-Ru-1 by reaction of (E)-hex-2-en-1-ol (29 $\mu \mathrm{L}, 0.25$ mmol) with dibenzo[b,d]thiophen-2-ylboronic acid (171 mg, 0.75 mmol) and was isolated by column chromatography (silica gel, petroleum ether to petroleum ether/ethyl acetate $85: 15)$ to give a yellow solid, mp [66.4 $-66.9{ }^{\circ} \mathrm{C}$ ], in $33 \%$ yield (35 mg); NMR yield $42 \%$.

${ }^{1} \mathbf{H}$ NMR $\left(500 \mathrm{MHz}, \mathrm{CDCl}_{3}\right) \delta 8.22-8.13(\mathrm{~m}, 2 \mathrm{H}), 7.88-7.80(\mathrm{~m}, 2 \mathrm{H}), 7.52-7.40(\mathrm{~m}$, $3 \mathrm{H}), 4.87(\mathrm{td}, J=7.8,7.0,2.8 \mathrm{~Hz}, 1 \mathrm{H}), 1.97-1.85(\mathrm{~m}, 2 \mathrm{H}), 1.84-1.77(\mathrm{~m}, 1 \mathrm{H}), 1.51-$ $1.42(\mathrm{~m}, 1 \mathrm{H}), 1.37-1.28(\mathrm{~m}, 5 \mathrm{H}), 0.93-0.83(\mathrm{~m}, 3 \mathrm{H})$.

${ }^{13} \mathbf{C}\left\{{ }^{1} \mathbf{H}\right\}$ NMR $\left(126 \mathrm{MHz}, \mathrm{CDCl}_{3}\right) \delta 141.6,140.0,138.7,135.8,135.6,126.9,125.0,124.5$, $123.0,122.9,121.8,119.0,75.0,39.6,31.9,25.7,22.7,14.2$.

HRMS (ESI) m/z: [M+H-H $\left.\mathrm{H}_{2}\right]^{+}$Calcd for $\mathrm{C}_{18} \mathrm{H}_{19} \mathrm{~S}$ 267.1202; Found 267.1197.

SFC with Chiralpak IG-3, 20\% iPrOH / 80\% CO $2,1.2 \mathrm{~mL} / \mathrm{min}$, $\mathrm{t}$ (major, (R)-3ao) $=3.58$ min., $\mathrm{t}($ minor, $(\mathbf{S})-\mathbf{3 a o})=3.89 \mathrm{~min}$.

Specific rotation: $[\alpha]_{\mathrm{D}}{ }^{20}+15.8^{\circ}\left(\mathrm{c} 0.83, \mathrm{CHCl}_{3}\right)$ for an enantiomerically enriched sample of $95: 5$ er. The absolute configuration was assigned by analogy to (R)-3ar and it was not further verified.

\section{(R)-1-(benzo[d][1,3]dioxol-5-yl)hexan-1-ol (3ap)}

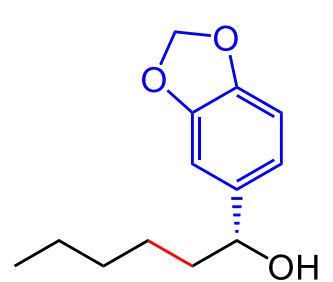

The compound 3ap was prepared according to General procedure 1 with (R,R)-Ru-1 by reaction of (E)-hex-2-en-1-ol $(29 \mu \mathrm{L}, 0.25$ mmol) with benzo[d][1,3]dioxol-5-ylboronic acid (124 mg, 0.75 mmol) and was isolated by column chromatography (silica gel, petroleum ether to petroleum ether/ethyl acetate 85:15) to give a white solid, $\mathrm{mp}\left[43.6-44.0^{\circ} \mathrm{C}\right]$, in $60 \%$ yield $(33 \mathrm{mg})$, NMR yield $66 \%$.

${ }^{1} \mathbf{H}$ NMR $\left(500 \mathrm{MHz}, \mathrm{CDCl}_{3}\right) \delta 6.84(\mathrm{~d}, J=1.4 \mathrm{~Hz}, 1 \mathrm{H}), 6.79-6.70(\mathrm{~m}, 2 \mathrm{H}), 5.93(\mathrm{~s}, 2 \mathrm{H})$, $4.54(\mathrm{dd}, J=7.3,6.1 \mathrm{~Hz}, 1 \mathrm{H}), 2.00(\mathrm{~s}, 1 \mathrm{H}), 1.80-1.70(\mathrm{~m}, 1 \mathrm{H}), 1.69-1.58(\mathrm{~m}, 1 \mathrm{H}), 1.44$ - $1.32(\mathrm{~m}, 1 \mathrm{H}), 1.32-1.17(\mathrm{~m}, 5 \mathrm{H}), 0.91-0.82(\mathrm{~m}, 3 \mathrm{H})$.

${ }^{13} \mathbf{C}\left\{{ }^{1} \mathbf{H}\right\} \mathbf{N M R}\left(126 \mathrm{MHz}, \mathrm{CDCl}_{3}\right) \delta 147.8,146.9,139.2,119.4,108.1,106.5,101.0,74.6$, $39.1,31.8,25.6,22.7,14.1$. 
HRMS (ESI) m/z: [M+H-H $\left.\mathrm{H}_{2} \mathrm{O}\right]^{+}$Calcd for $\mathrm{C}_{13} \mathrm{H}_{17} \mathrm{O}_{2}$ 205.1223; Found 205.1225.

SFC with Chiralpak IC-3, 5\% iPrOH / 95\% CO $2,1.2 \mathrm{~mL} / \mathrm{min}, \mathrm{t}($ major, $(\mathbf{R})-3 a p)=3.95$ min., $\mathrm{t}(\operatorname{minor},(\mathbf{S})-3 \mathbf{a p})=4.38 \mathrm{~min}$.

Specific rotation: $[\alpha]_{\mathrm{D}}{ }^{20}+21.8^{\circ}\left(\mathrm{c} 0.38, \mathrm{CHCl}_{3}\right)$ for an enantiomerically enriched sample of $95: 5$ er. The absolute configuration was assigned by analogy to (R)-3ab and (R)-3ak and it was not further verified.

\section{(R)-1-(naphthalen-2-yl)hexan-1-ol (3aq)}

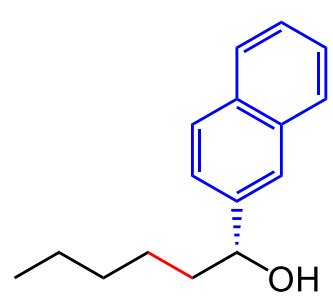

The compound 3ar was prepared according to General procedure 1 with (R,R)-Ru-1 by reaction of (E)-hex-2-en-1-ol $(29 \mu \mathrm{L}, 0.25$ mmol) with naphthalen-2-ylboronic acid (129 mg, $0.75 \mathrm{mmol})$ and was isolated by column chromatography (silica gel, petroleum ether to petroleum ether/ethyl acetate 90:10) to give a white solid, mp $\left[71.3-72.0{ }^{\circ} \mathrm{C}\right]$, in $80 \%$ yield $(45 \mathrm{mg})$, NMR yield $86 \%$.

${ }^{1} \mathbf{H}$ NMR $\left(500 \mathrm{MHz}, \mathrm{CDCl}_{3}\right) \delta 7.88-7.79(\mathrm{~m}, 3 \mathrm{H}), 7.77(\mathrm{~s}, 1 \mathrm{H}), 7.54-7.42(\mathrm{~m}, 3 \mathrm{H}), 4.82$ $(\mathrm{dd}, J=7.4,6.0 \mathrm{~Hz}, 1 \mathrm{H}), 2.11(\mathrm{~s}, 1 \mathrm{H}), 1.94-1.84(\mathrm{~m}, 1 \mathrm{H}), 1.84-1.75(\mathrm{~m}, 1 \mathrm{H}), 1.51-$ $1.39(\mathrm{~m}, 1 \mathrm{H}), 1.37-1.25(\mathrm{~m}, 5 \mathrm{H}), 0.94-0.83(\mathrm{~m}, 3 \mathrm{H})$.

${ }^{13} \mathbf{C}\left\{{ }^{1} \mathbf{H}\right\}$ NMR $\left(126 \mathrm{MHz}, \mathrm{CDCl}_{3}\right) \delta 142.4,133.4,133.1,128.3,128.0,127.8,126.2,125.9$, $124.7,124.2,74.9,39.0,31.9,25.6,22.7,14.2$.

HRMS (ESI) m/z: [M+H-H $\left.\mathrm{H}_{2} \mathrm{O}\right]^{+}$Calcd for $\mathrm{C}_{16} \mathrm{H}_{19}$ 211.1481; Found 211.1479.

SFC with Chiralpak ID-3, 5\% iPrOH / 95\% $\mathrm{CO}_{2}, 1.2 \mathrm{~mL} / \mathrm{min}, \mathrm{t}($ major, $(\mathbf{R})-3 a q)=3.78$ min., $\mathrm{t}(\operatorname{minor},(\mathbf{S})-3 \mathbf{a q})=4.09 \mathrm{~min}$.

Specific rotation: $[\alpha]_{\mathrm{D}}^{20}+27.8^{\circ}\left(\mathrm{c} 1.43, \mathrm{CHCl}_{3}\right)$ or $[\alpha]_{\mathrm{D}}{ }^{20}+21.5^{\circ}\left(\mathrm{c} 1.43, \mathrm{C}_{2} \mathrm{H}_{5} \mathrm{OH}\right)$ for an enantiomerically enriched sample of $98: 2$ er. The absolute configuration was determined by comparison of the optical rotation measured in $\mathrm{C}_{2} \mathrm{H}_{5} \mathrm{OH}$ with that reported in literature for the opposite enantiomer $[\alpha]_{\mathrm{D}}^{23}-23.0^{\circ}$ (c 1.0, $\left.\mathrm{C}_{2} \mathrm{H}_{5} \mathrm{OH}\right), 95: 5 .^{11}$

\section{(R)-1-(naphthalen-1-yl)hexan-1-ol (3ar)}

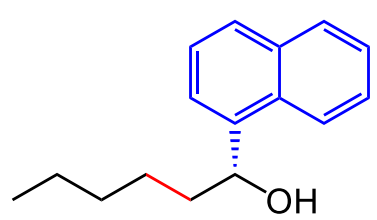

The compound 3as was prepared according to General procedure 1 with $(\mathrm{R}, \mathrm{R})-\mathbf{R u - 1}$ by reaction of (E)-hex-2-en-1-ol (29 $\mu \mathrm{L}, 0.25 \mathrm{mmol})$ with naphthalen-1-ylboronic acid (129 mg, 
$0.75 \mathrm{mmol}$ ) and was isolated by column chromatography (silica gel, petroleum ether to petroleum ether/ethyl acetate $90: 10$ ) to give a pale yellow solid, mp $\left[66.5-66.9^{\circ} \mathrm{C}\right]$, in $31 \%$ yield (18 $\mathrm{mg}$ ), NMR yield $35 \%$.

${ }^{1} \mathbf{H}$ NMR $\left(500 \mathrm{MHz}, \mathrm{CDCl}_{3}\right) \delta 8.12(\mathrm{dd}, \mathrm{J}=8.1,1.6 \mathrm{~Hz}, 1 \mathrm{H}), 7.88(\mathrm{dd}, \mathrm{J}=7.6,1.9 \mathrm{~Hz}$, 1H), $7.78(\mathrm{~d}, \mathrm{~J}=8.1 \mathrm{~Hz}, 1 \mathrm{H}), 7.64(\mathrm{dd}, \mathrm{J}=7.2,1.3 \mathrm{~Hz}, 1 \mathrm{H}), 7.56-7.41(\mathrm{~m}, 3 \mathrm{H}), 5.45(\mathrm{dd}$, $\mathrm{J}=8.0,4.7 \mathrm{~Hz}, 1 \mathrm{H}), 2.07(\mathrm{~s}, 1 \mathrm{H}), 2.03-1.82(\mathrm{~m}, 2 \mathrm{H}), 1.62-1.50(\mathrm{~m}, 1 \mathrm{H}), 1.50-1.39$ (m, 1H), $1.39-1.28(\mathrm{~m}, 4 \mathrm{H}), 0.95-0.87(\mathrm{~m}, 3 \mathrm{H})$.

${ }^{13} \mathbf{C}\left\{{ }^{1} \mathbf{H}\right\}$ NMR $\left(126 \mathrm{MHz}, \mathrm{CDCl}_{3}\right) \delta 140.8,133.9,130.6,129.0,128.0,126.0,125.6,125.5$, $123.3,122.9,71.4,38.5,31.9,26.1,22.8,14.2$.

HRMS (ESI) m/z: [M+H-H $\left.\mathrm{H}_{2} \mathrm{O}\right]^{+}$Calcd for $\mathrm{C}_{16} \mathrm{H}_{19}$ 211.1481; Found 211.1484.

SFC with Chiralpak IC-3, 5\% iPrOH / 95\% $\mathrm{CO}_{2}, 1.2 \mathrm{~mL} / \mathrm{min}, \mathrm{t}$ (minor, (S)-3ar) $=5.53$ min, $\mathrm{t}$ (major, $(\mathbf{R})-3 a r)=7.49$ min.

Specific rotation: $[\alpha]_{\mathrm{D}}^{20}+18.5\left(\mathrm{c} 0.4, \mathrm{CHCl}_{3}\right)$ or $[\alpha]_{\mathrm{D}}^{20}+30.7^{\circ}\left(\mathrm{c} 0.4, \mathrm{C}_{2} \mathrm{H}_{5} \mathrm{OH}\right)$ for an enantiomerically enriched sample of $79: 21$ er. The absolute configuration was determined by comparison of the optical rotation measured in $\mathrm{C}_{2} \mathrm{H}_{5} \mathrm{OH}$ with that reported in literature for the opposite enantiomer $[\alpha]_{\mathrm{D}^{23}}-45.0^{\circ}\left(\mathrm{c} 1.0, \mathrm{C}_{2} \mathrm{H}_{5} \mathrm{OH}\right), 95: 5 .^{11}$

\section{(R)-1-(phenanthren-9-yl)hexan-1-ol (3as)}

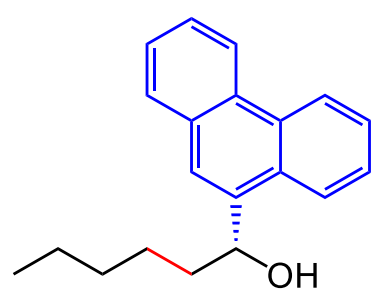

The compound 3as was prepared according to General procedure 1 with $(\mathrm{R}, \mathrm{R})-\mathbf{R u}-\mathbf{1}$ by reaction of (E)-hex-2-en-1-ol (29 $\mu \mathrm{L}, 0.25 \mathrm{mmol})$ with phenanthren-9-ylboronic acid (166 mg, $0.75 \mathrm{mmol}$ ) and was isolated by column chromatography (silica gel, petroleum ether to petroleum ether/ethyl acetate 90:10) to give a white solid, mp [81.9 - 82.6 $\left.{ }^{\circ} \mathrm{C}\right]$, in 10\% yield (7 mg), NMR yield $15 \%$.

${ }^{1} \mathbf{H}$ NMR $\left(500 \mathrm{MHz} \mathrm{CDCl}_{3}\right) \delta 8.76(\mathrm{dd}, J=8.0,1.6 \mathrm{~Hz}, 1 \mathrm{H}), 8.67(\mathrm{~d}, J=8.1 \mathrm{~Hz}, 1 \mathrm{H})$, $8.16(\mathrm{dd}, J=8.0,1.6 \mathrm{~Hz}, 1 \mathrm{H}), 7.96-7.85(\mathrm{~m}, 2 \mathrm{H}), 7.73-7.53(\mathrm{~m}, 4 \mathrm{H}), 5.49(\mathrm{dt}, J=7.8$, $3.6 \mathrm{~Hz}, 1 \mathrm{H}), 2.11-2.01(\mathrm{~m}, 1 \mathrm{H}), 1.99(\mathrm{~d}, J=3.5 \mathrm{~Hz}, 1 \mathrm{H}), 1.97-1.86(\mathrm{~m}, 1 \mathrm{H}), 1.68-1.46$ (m, 2H), $1.44-1.28(\mathrm{~m}, 4 \mathrm{H}), 0.96-0.85(\mathrm{~m}, 3 \mathrm{H})$.

${ }^{13} \mathbf{C}\left\{{ }^{1} \mathbf{H}\right\}$ NMR $\left(126 \mathrm{MHz}, \mathrm{CDCl}_{3}\right) \delta 138.9,131.6,130.9,130.1,129.8,128.9,126.9,126.7$ x $2,126.4,124.0,123.6,123.5,122.6,71.7,38.2,31.9,26.2,22.8,14.2$.

HRMS (ESI) m/z: [M+H-H $\left.{ }_{2} \mathrm{O}\right]^{+}$Calcd for $\mathrm{C}_{20} \mathrm{H}_{21}$ 261.1638; Found 261.1637. 
SFC with Chiralpak IG-3, 20\% iPrOH / 80\% $\mathrm{CO}_{2}, 1.2 \mathrm{~mL} / \mathrm{min}, \mathrm{t}$ (major, $\left.(\mathbf{R})-3 \mathbf{a s}\right)=4.57$ min., $\mathrm{t}($ minor, $(\mathbf{S})-3 \mathbf{a s})=5.67 \mathrm{~min}$.

Specific rotation: $[\alpha]_{\mathrm{D}}{ }^{20}+30.3^{\circ}\left(\mathrm{c} 0.15, \mathrm{CHCl}_{3}\right)$ for an enantiomerically enriched sample of 72 : 28 er. The absolute configuration was assigned by analogy to (R)-3ar and (R)-3ar and it was not further verified. 


\section{MULTI-CATALYTIC ENANTIOSELECTIVE CONVERSION OF ALKENES TO SECONDARY BENZYLIC ALCOHOLS}

\section{A. Optimization of the Reaction Conditions and Control Experiments}

Table S1. Metathesis optimization

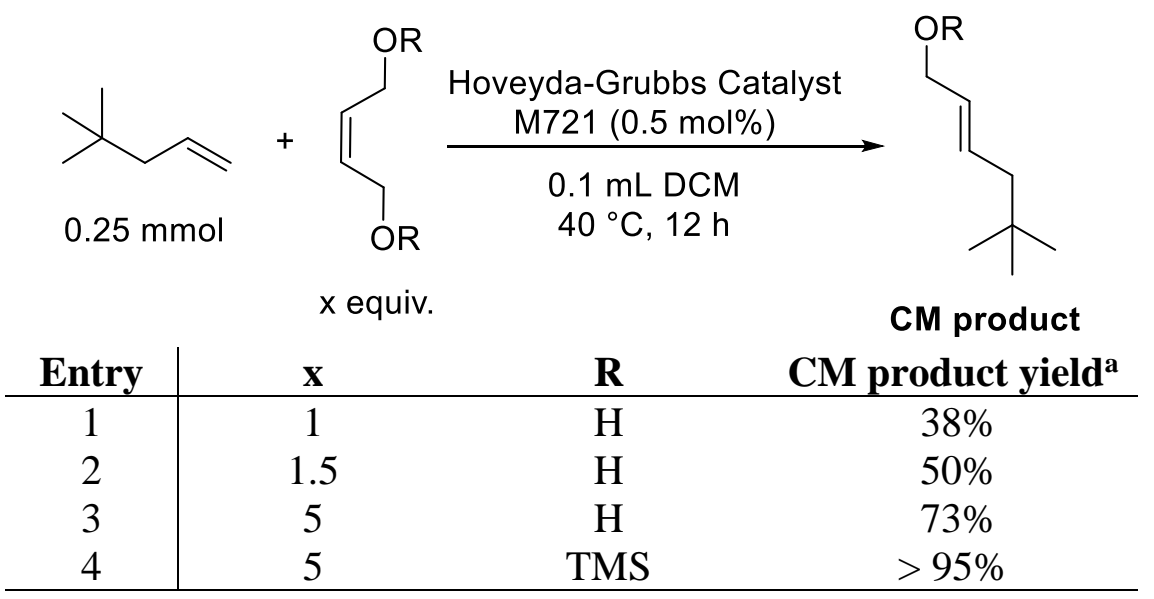

${ }^{a}$ Determined by GC analysis.

Table S2. Full sequence optimization

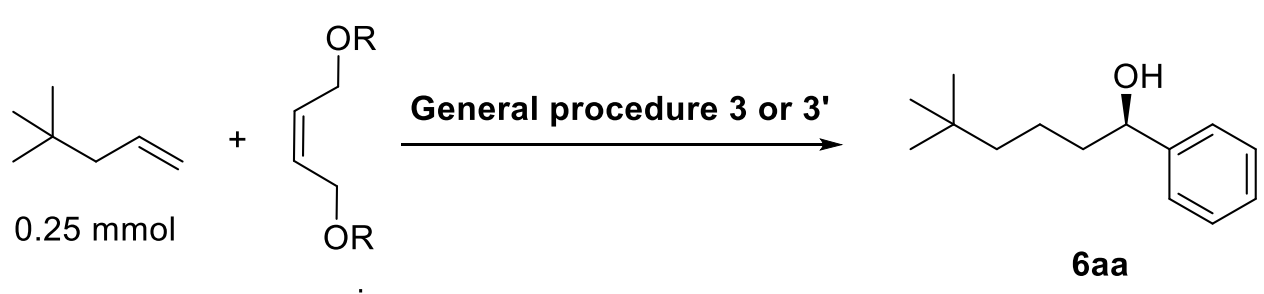

\begin{tabular}{c|ccc}
\multicolumn{5}{|c}{ x equiv. } & $\mathbf{R}$ & 6aa yield $^{\mathbf{a}}$ \\
\hline Entry & $\mathbf{x}$ & $\mathrm{H}$ & $9 \%$ \\
$1^{\mathrm{b}}$ & 1 & $\mathrm{H}$ & $11 \%$ \\
$2^{\mathrm{b}}$ & 1.5 & $\mathrm{H}$ & $<5 \%$ \\
$3^{\mathrm{b}}$ & 5 & $\mathrm{TMS}$ & $88 \%$ \\
$4^{\mathrm{c}}$ & 5 &
\end{tabular}

${ }^{\mathrm{a}}$ Determined by ${ }^{1} \mathrm{H}$ NMR with TMB (1,3,5-Trimethoxybenzene)

as an internal standard.

${ }^{\text {b }}$ Performed using General procedure 3' (see below).

${ }^{\mathrm{c}}$ Performed using General procedure 3 (see below). 


\section{B. General Procedure}

\section{General procedure 3: Multi-catalytic enantioselective conversion of alkenes to secondary benzylic alcohols}

All following operations were performed in a nitrogen-filled glovebox. A $4 \mathrm{ml}$ vial equipped with stirring bar $(2 \mathrm{~mm} \times 5 \mathrm{~mm})$ was charged with an alkene $(0.25 \mathrm{mmol}, 1$ equiv), bis-TMS protected (Z)-butenodiol S1 (290.6 mg, 5 equiv, $1.25 \mathrm{mmol}$ ), and a solution of Hoveyda-Grubbs Catalyst ${ }^{\circledR}$ M721 (0.71 mg, 0.5 mol\% in $\left.100 \mu \mathrm{L} \mathrm{DCM}\right)$. Next, the vial was sealed with a Teflon-lined screw cap, placed in a preheated aluminum block at $40{ }^{\circ} \mathrm{C}$, and allowed to stir at $800 \mathrm{rpm}$ for $12 \mathrm{~h}$. After that, the vial was removed from the heating block and let to cool to room temperature. A degassed solution of trifluoroacetic acid in water $(40 \% \mathrm{v} / \mathrm{v} ; 50 \mu \mathrm{L})$ was added, the vial was sealed, shaken, and let to stir vigorously for $10 \mathrm{~min}$. A degassed saturated water solution of $\mathrm{NaHCO}_{3}(0.5 \mathrm{~mL})$ was added, and the mixture was allowed to stir for $10 \mathrm{~min}$ with free evolution of $\mathrm{CO}_{2}$. A portion of DCM (0.4 mL) was added, the vial was sealed and shaken. Upon phase separation, the aqueous phase was separated off by either (i) gently removing the top aqueous layer with the aid of a syringe equipped with a needle, or (ii) carefully transferring the bottom organic layer to a new vial with the aid of a syringe equipped with a needle. Albeit the first procedure was faster, it was found to be less reproducible on a small scale. Therefore, the latter procedure was used preferably. In such a case, the aqueous phase was washed additionally with DCM $(0.4 \mathrm{~mL})$. Then, organic fractions were combined, dried over anhydrous $\mathrm{Na}_{2} \mathrm{SO}_{4}(\sim 200 \mathrm{mg})$, filtered $\left(\mathrm{Na}_{2} \mathrm{SO}_{4}\right.$ was washed with an additional portion of DCM $(\sim 0.4 \mathrm{~mL}))$, and followed by the removal of the volatiles from the filtrate under reduced pressure. The solution of Alkene Zipper catalyst Ru-2 (acetonitrile(cyclopentadienyl)[2-(di-i-propylphosphino)-4-( $t$-butyl)-1-methyl-1Himidazole]ruthenium(II) hexafluorophosphate; $3.8 \mathrm{mg}, 0.025$ equiv, $6.3 \times 10^{-3} \mathrm{mmol}$ in 1 ml DCM) was added to the residue, the reaction mixture was placed in a preheated aluminum block at $70{ }^{\circ} \mathrm{C}$ and was allowed to stir for $6 \mathrm{~h}$. After that, the vial was removed from the heating block and let to cool to room temperature. (In the meantime, a stock solution of Ru-1 was prepared by allowing to stir a mixture of $\left[\mathrm{Ru}(\mathrm{p} \text {-cymene }) \mathrm{Cl}_{2}\right]_{2}(7.7$ $\mathrm{mg}, 0.050$ equiv, $\left.1.25 \times 10^{-2} \mathrm{mmol}\right)$ and Me-BIPAM (20.9 $\mathrm{mg}, 0.11$ equiv, $2.75 \times 10^{-2}$ 
mmol) in toluene ( $1 \mathrm{~mL}$ ) for $1 \mathrm{~h}$ at $\mathrm{rt}$ ). Then, the solution of $\mathbf{R u - 1}$, the solution of $\mathrm{K}_{2} \mathrm{CO}_{3}$ (34.6 mg, 1.0 equiv, $0.25 \mathrm{mmol})$ in degassed water $(150 \mu \mathrm{L})$, and arylboronic acid (3.0 equiv, $0.75 \mathrm{mmol}$ ) were added to the reaction mixture. The vial was resealed with a Teflonlined screw cap, removed from the glovebox, placed in a preheated aluminum block at 60 ${ }^{\circ} \mathrm{C}$, and allowed to stir at $800 \mathrm{rpm}$ for $6 \mathrm{~h}$. Next, the vial was removed from the heating block. (The yield was measured by GC-MS and/or NMR analysis using dodecane or 1,3,5trimethoxybenezene as an internal standards). The reaction mixture was diluted with ethyl acetate, Celite ( $\sim \mathrm{g}$ ) was added, and the volatiles were removed under reduces pressure. The residue was subjected to column chromatography on silica gel ( $24 \mathrm{~g}$ ), conducted with the aid of a Combiflash instrument, using a mixture of petroleum ether and ethyl acetate (usually with gradient of 100:0 - 85:15) as the eluent. Fractions containing the pure product (judged by the TLC and/or GC analyses) were combined, and the solvent was evaporated, yielding the target product.

\section{General procedure 3': Multi-catalytic enantioselective conversion of alkenes to secondary benzylic alcohols}

All following operations were performed in a nitrogen-filled glovebox. A $4 \mathrm{ml}$ vial equipped with stirring bar ( $2 \mathrm{~mm}$ x $5 \mathrm{~mm}$ ) was charged with alkene ( $0.25 \mathrm{mmol}, 1$ equiv), appropriate amount of (Z)-butenodiol ( 1 - 5 equiv) and a solution of Hoveyda-Grubbs Catalyst ${ }^{\circledR}$ M721 $(0.71 \mathrm{mg}, 0.5 \mathrm{~mol} \%$ in $100 \mu \mathrm{L} \mathrm{DCM})$. Next, the vial was sealed with a Teflon-lined screw cap, placed in a preheated aluminum block at $40{ }^{\circ} \mathrm{C}$, and allowed to stir at $800 \mathrm{rpm}$ for $12 \mathrm{~h}$. After that, the vial was removed from the heating block and let to cool to room temperature. The solution of Alkene Zipper catalyst Ru-2 (acetonitrile(cyclopentadienyl)[2-(di- $i$-propylphosphino)-4-( $t$-butyl)-1-methyl-1Himidazole]ruthenium(II) hexafluorophosphate; $3.8 \mathrm{mg}$, 0.025 equiv, $6.3 \times 10^{-3} \mathrm{mmol}$ in 1 $\mathrm{ml}$ DCM) was added, the reaction mixture was placed in a preheated aluminum block at 70 ${ }^{\circ} \mathrm{C}$ and allowed to stir for $6 \mathrm{~h}$. After that, the vial was removed from the heating block and let to cool to room temperature. (In the meantime, a stock solution of Ru-1 was prepared by allowing to stir a mixture of $\left[\mathrm{Ru}(\mathrm{p} \text {-cymene }) \mathrm{Cl}_{2}\right]_{2}\left(7.7 \mathrm{mg}, 0.050\right.$ equiv, $1.25 \times 10^{-2}$ mmol) and Me-BIPAM (20.9 mg, 0.11 equiv, $\left.2.75 \times 10^{-2} \mathrm{mmol}\right)$ in toluene $(1 \mathrm{~mL})$ for $1 \mathrm{~h}$ at rt). Then, the solution of Ru-1, the solution of $\mathrm{K}_{2} \mathrm{CO}_{3}$ (34.6 mg, 1 equiv, $0.25 \mathrm{mmol}$ ) in 
degassed water $(150 \mu \mathrm{L})$, and arylboronic acid (3.0 equiv, $0.75 \mathrm{mmol}$ ) were added to the reaction mixture. The vial was resealed with a Teflon-lined screw cap, removed from the glovebox, placed in a preheated aluminum block at $60{ }^{\circ} \mathrm{C}$, and allowed to stir at $800 \mathrm{rpm}$ for $6 \mathrm{~h}$. Next, the vial was removed from the heating block. The reaction mixture was diluted with ethyl acetate, Celite ( 2 g) was added, and the volatiles were removed under reduces pressure. (The yield was measured by GC-MS and/or NMR analysis using dodecane or 1,3,5-trimethoxybenezene as an internal standards). The residue was subjected to column chromatography on silica gel ( $24 \mathrm{~g})$, conducted with the aid of a Combiflash instrument, using a mixture of petroleum ether and ethyl acetate (usually with gradient of 100:0 - 85:15) as the eluent. Fractions containing the pure product (judged by the TLC and/or GC analyses) were combined, and the solvent was evaporated, yielding the target product. 


\section{Full Characterization of Reaction Products}

\section{(R)-5,5-dimethyl-1-phenylhexan-1-ol (6aa)}

$\underbrace{\text { The compound }(\mathrm{R}) \text {-6aa was prepared according to General }}_{\mathrm{OH}}$ (24.6 $\mathrm{mg}, 0.25 \mathrm{mmol})$ with phenylboronic acid $(91.5 \mathrm{mg}, 0.75 \mathrm{mmol})$ and was isolated by column chromatography (silica gel, petroleum ether to petroleum ether/ethyl acetate $85: 15$ ) to give a white solid in $79 \%$ yield (40.6 mg); NMR yield $88 \%$. The enantiomeric ratio for the isolated material was determined to be $98: 2(\mathrm{R}: \mathrm{S})$.

(S)-5,5-dimethyl-1-phenylhexan-1-ol (6aa) - $2.44 \mathbf{m m o l}$ scale reaction

Ph The compound (S)-6aa was prepared on a big scale according to section III, using $(S, S)$-Ru-1 by reaction of 5,5-dimethylpent-1-ene (240 mg, $2.44 \mathrm{mmol}$, 1.0 equiv), bis-TMS protected Z-butenodiol (S1, $2.84 \mathrm{~g}, 12.2 \mathrm{mmol}, 5$ equiv), and phenylboronic acid (893 mg, $7.32 \mathrm{mmol}, 3$ equiv), and was isolated by column chromatography (silica gel, petroleum ether to petroleum ether/ethyl acetate 85:15) to give a yellowish solid, $\mathrm{mp}\left[52.7-53.2{ }^{\circ} \mathrm{C}\right]$, in $77 \%(389 \mathrm{mg})$. The enantiomeric ratio for the isolated material was determined to be $96: 4(\mathrm{~S}: \mathrm{R})$.

The NMR data for the isolated material from the small scale and the big scale reactions matched.

${ }^{1} \mathbf{H}$ NMR $\left(500 \mathrm{MHz}, \mathrm{CDCl}_{3}\right) \delta 7.38$ - $7.34(\mathrm{~m}, 4 \mathrm{H}), 7.31$ - $7.26(\mathrm{~m}, 1 \mathrm{H}), 4.68(\mathrm{dd}, J=7.9$, $5.5 \mathrm{~Hz}, 1 \mathrm{H}), 1.82-1.72(\mathrm{~m}, 2 \mathrm{H}), 1.72-1.61(\mathrm{~m}, 1 \mathrm{H}), 1.53-1.35(\mathrm{~m}, 1 \mathrm{H}), 1.35-1.12$ $(\mathrm{m}, 3 \mathrm{H}), 0.86(\mathrm{~s}, 9 \mathrm{H})$.

${ }^{13} \mathbf{C}\left\{{ }^{1} \mathbf{H}\right\}$ NMR $\left(126 \mathrm{MHz}, \mathrm{CDCl}_{3}\right) \delta 145.2,128.6,127.6,126.0,74.9,44.2,40.2,30.5,29.5$, 21.1 .

HRMS (ESI) m/z: [M+H-H 2$]^{+}$Calcd. for $\mathrm{C}_{14} \mathrm{H}_{21}$ 189.1638; Found 189.1640

SFC with Chiralpak ID-3, 2\% iPrOH / 98\% CO $2,1.2 \mathrm{~mL} / \mathrm{min}, \mathrm{t}((\mathbf{R})-6 \mathbf{a a})=2.03 \mathrm{~min} ., \mathrm{t}($ $(\mathbf{S})-\mathbf{6 a a})=2.40 \mathrm{~min}$.

Specific rotation: $[\alpha]_{\mathrm{D}}{ }^{20}-25.3^{\circ}\left(\mathrm{c} 1.02, \mathrm{CHCl}_{3}\right)$ for an enantiomerically enriched sample with (S)-6aa enantiomer as a major with $96: 4$ er. The absolute configuration was assigned by analogy to (R)-3aa and it was not further verified. 


\section{(R)-1-phenylundecan-1-ol (6ba)}

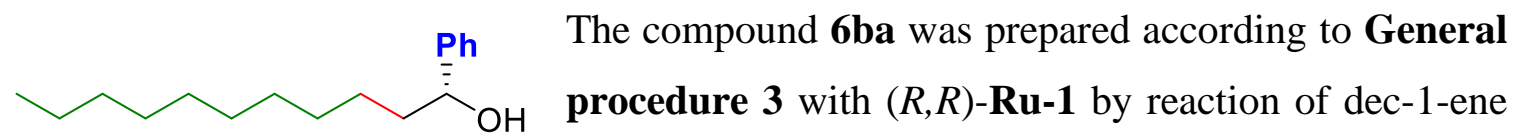

(35.07 mg, $0.25 \mathrm{mmol})$ with phenylboronic acid $(91.5 \mathrm{mg}, 0.75 \mathrm{mmol})$ and was isolated by column chromatography (silica gel, petroleum ether to petroleum ether/ethyl acetate $85: 15$ ) to give a colorless oil in 64\% yield (39.7 mg); NMR yield $65 \%$.

${ }^{1} \mathbf{H}$ NMR $\left(500 \mathrm{MHz}, \mathrm{CDCl}_{3}\right) \delta 7.40$ - $7.32(\mathrm{~m}, 4 \mathrm{H}), 7.32$ - $7.26(\mathrm{~m}, 1 \mathrm{H}), 4.66(\mathrm{dd}, J=7.6$, $5.8 \mathrm{~Hz}, 1 \mathrm{H}), 1.85-1.65(\mathrm{~m}, 3 \mathrm{H}), 1.51-1.37(\mathrm{~m}, 1 \mathrm{H}), 1.37-1.14(\mathrm{~m}, 15 \mathrm{H}), 0.88(\mathrm{t}, J=$ $6.9 \mathrm{~Hz}, 3 \mathrm{H})$.

${ }^{13} \mathbf{C}\left\{{ }^{1} \mathbf{H}\right\}$ NMR $\left(126 \mathrm{MHz}, \mathrm{CDCl}_{3}\right) \delta 145.1,128.6,127.6,126.0,74.9,39.3,32.0,29.74$, $29.73,29.69,29.67,29.5,26.0,22.8,14.3$.

HRMS (ESI) m/z: [M+H-H $\left.{ }_{2} \mathrm{O}\right]^{+}$Calcd. for $\mathrm{C}_{17} \mathrm{H}_{27}$ 231.2107; Found 231.2111

SFC with Chiralpak IG-3, 5\% iPrOH / 95\% CO $2,1.2 \mathrm{~mL} / \mathrm{min}, \mathrm{t}($ minor, $(\mathbf{S})-6 \mathbf{b a})=3.38$ min., $t$ (major, $(\mathbf{R})-6 b a)=3.66 \min$.

Specific rotation: $[\alpha]_{\mathrm{D}}{ }^{20}+20.0^{\circ}\left(\mathrm{c} 1.02, \mathrm{CHCl}_{3}\right)$ for an enantiomerically enriched sample of $97: 3$ er. The absolute configuration was determined by comparison of the optical rotation with that reported in literature for the opposite enantiomer $[\alpha]_{\mathrm{D}}{ }^{23}-21.2^{\circ}$ (c 3.00, $\left.\mathrm{CHCl}_{3}\right), 98: 2 .^{12}$

\section{(R)-3-cyclohexyl-1-phenylpropan-1-ol (6ca)}

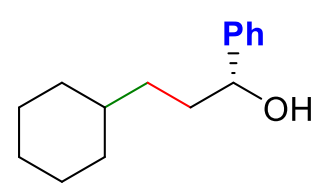

The compound 6ca was prepared according to General procedure 3 with $(R, R)-\mathbf{R u}-\mathbf{1}$ by reaction of vinylcyclopetroleum ether $(27.6 \mathrm{mg}$, $0.25 \mathrm{mmol})$ with phenylboronic acid $(91.5 \mathrm{mg}, 0.75 \mathrm{mmol})$ and was isolated by column chromatography (silica gel, petroleum ether to petroleum ether/ethyl acetate $85: 15)$ to give a white solid, $\mathrm{mp}\left[73.2-73.9^{\circ} \mathrm{C}\right]$, in $72 \%$ yield $(39.1 \mathrm{mg})$; NMR yield $72 \%$.

${ }^{1} \mathbf{H}$ NMR $\left(500 \mathrm{MHz}, \mathrm{CDCl}_{3}\right) \delta 7.38-7.32(\mathrm{~m}, 4 \mathrm{H}), 7.31-7.27(\mathrm{~m}, 1 \mathrm{H}), 4.63(\mathrm{dd}, J=7.5$, $5.8 \mathrm{~Hz}, 1 \mathrm{H}), 1.92-1.52(\mathrm{~m}, 8 \mathrm{H}), 1.44-1.27(\mathrm{~m}, 1 \mathrm{H}), 1.26-1.03(\mathrm{~m}, 5 \mathrm{H}), 0.96-0.80$ $(\mathrm{m}, 2 \mathrm{H})$. 
${ }^{13} \mathbf{C}\left\{{ }^{1} \mathbf{H}\right\}$ NMR $\left(126 \mathrm{MHz}, \mathrm{CDCl}_{3}\right) \delta 145.1,128.6,127.6,126.1,75.2,37.8,36.6,33.5,33.4$, $26.8,26.5$.

HRMS (ESI) m/z: [M+H-H $\left.\mathrm{H}_{2} \mathrm{O}\right]^{+}$Calcd. for $\mathrm{C}_{15} \mathrm{H}_{21}$ 201.1638; Found 201.1639

SFC with Chiralpak ID-3, 5\% iPrOH / 95\% CO $2,1.2 \mathrm{~mL} / \mathrm{min}, \mathrm{t}($ minor, $(\mathbf{S})-\mathbf{6 c a})=2.70$ min., $\mathrm{t}($ major, $(\mathbf{R})-\mathbf{6 c a})=2.90 \mathrm{~min}$.

Specific rotation: $[\alpha]_{\mathrm{D}}^{20}+26.6^{\circ}\left(\mathrm{c} 1.00, \mathrm{CHCl}_{3}\right.$ ) for an enantiomerically enriched sample of $97: 3$ er. The absolute configuration was assigned by analogy to (R)-3aa and it was not further verified.

\section{(R)-1,4-diphenylbutan-1-ol (6da)}

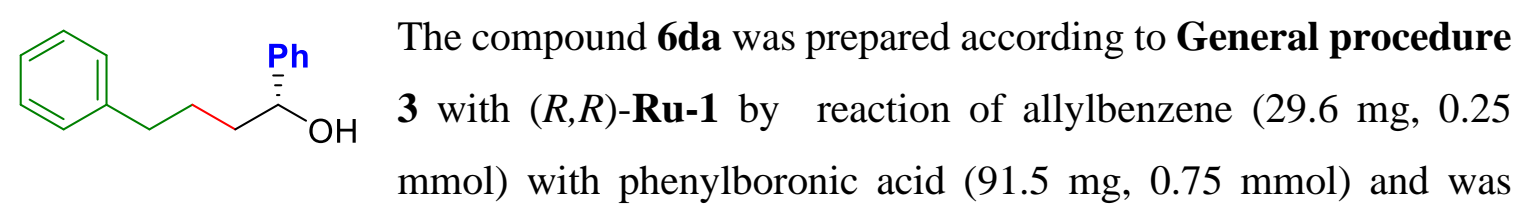
isolated by column chromatography (silica gel, petroleum ether to petroleum ether/ethyl acetate $85: 15)$ to give a colorless oil in $48 \%$ yield (26.9 mg), NMR yield $53 \%$.

${ }^{1} \mathbf{H}$ NMR $\left(500 \mathrm{MHz}, \mathrm{CDCl}_{3}\right) \delta 7.39-7.28(\mathrm{~m}, 4 \mathrm{H}), 7.28-7.20(\mathrm{~m}, 3 \mathrm{H}), 7.17-7.10(\mathrm{~m}$, $3 \mathrm{H}), 4.66(\mathrm{t}, J=7.4,4.9 \mathrm{~Hz}, 1 \mathrm{H}), 2.61(\mathrm{t}, J=7.3 \mathrm{~Hz}, 2 \mathrm{H}), 2.03-1.66$ (m, 4H), 1.59 (dd, $J$ $=10.6,7.7 \mathrm{~Hz}, 1 \mathrm{H})$.

${ }^{13} \mathbf{C}\left\{{ }^{1} \mathbf{H}\right\}$ NMR $\left(126 \mathrm{MHz}, \mathrm{CDCl}_{3}\right) \delta$ 144.7, 142.3, 128.5, 128.4, 128.3, 127.6, 125.9, 125.8, 74.6, 38.6, 35.8, 27.6 .

HRMS (ESI) m/z: [M-H] ${ }^{+}$Calcd. for $\mathrm{C}_{16} \mathrm{H}_{27}$ 225.1274; Found 225.1271

SFC with Chiralpak IB N-3, 5\% iPrOH / 95\% CO $2,1.2 \mathrm{~mL} / \mathrm{min}$, $\mathrm{t}($ major, $(\mathbf{R})-\mathbf{6 d a})=7.25$ min., $\mathrm{t}(\operatorname{minor},(\mathbf{S})-\mathbf{6 d a})=8.40 \mathrm{~min}$.

Specific rotation: $[\alpha]_{\mathrm{D}}^{20}+16.4^{\circ}\left(\mathrm{c} 0.98, \mathrm{CHCl}_{3}\right)$ for an enantiomerically enriched sample of $97: 3$ er. $T$ The absolute configuration was assigned by analogy to (R)-3aa and it was not further verified. 


\section{(R)-3-(4-fluorophenyl)-1-phenylpropan-1-ol (6ea)}<smiles>OC(CCc1ccc(F)cc1)c1ccccc1</smiles>

The compound was prepared according to General procedure 3 with $(R, R)$-Ru-1 by reaction of 1-fluoro-4-vinylbenzene $(30.5 \mathrm{mg}$, $0.25 \mathrm{mmol})$ with phenylboronic acid $(91.5 \mathrm{mg}, 0.75 \mathrm{mmol})$ and was isolated by column chromatography (silica gel, petroleum ether to petroleum ether/ethyl acetate $85: 15)$ to give a white solid, mp [48.4 $-49.0{ }^{\circ} \mathrm{C}$ ], in $84 \%$ yield $(45.4$ mg); NMR yield $84 \%$.

${ }^{1}$ H NMR (500 MHz, CDCl $) \delta 7.29$ - 7.25 (m, 4H), 7.22 - $7.18(\mathrm{~m}, 1 \mathrm{H}), 7.08-7.02$ (m, 2H), $6.91-6.84(\mathrm{~m}, 2 \mathrm{H}), 4.58(\mathrm{dd}, \mathrm{J}=7.9,5.2 \mathrm{~Hz}, 1 \mathrm{H}), 2.64(\mathrm{ddd}, \mathrm{J}=15.1,9.8,5.7 \mathrm{~Hz}$, 1H), $2.56(\mathrm{ddd}, \mathrm{J}=14.0,9.6,6.6 \mathrm{~Hz}, 1 \mathrm{H}), 2.06-1.97(\mathrm{~m}, 1 \mathrm{H}), 1.94-1.88(\mathrm{~m}, 1 \mathrm{H}), 1.79$ (bs, 1H).

${ }^{13} \mathbf{C}\left\{{ }^{1} \mathbf{H}\right\}$ NMR $\left(126 \mathrm{MHz}, \mathrm{CDCl}_{3}\right) \delta 161.4(\mathrm{~d}, J=243.3 \mathrm{~Hz}), 144.6,137.5(\mathrm{~d}, J=3.2 \mathrm{~Hz})$, $129.9(\mathrm{~d}, J=7.8 \mathrm{~Hz}), 128.7,127.9,126.0,115.2(\mathrm{~d}, J=21.1 \mathrm{~Hz}), 73.9,40.7$ (d, $J=1.0$ $\mathrm{Hz}), 31.4(\mathrm{~d}, J=0.6 \mathrm{~Hz})$.

${ }^{19}$ F NMR (471 MHz, $\left.\mathrm{CDCl}_{3}\right) \delta-117.66--117.76(\mathrm{~m})$.

HRMS (ESI) m/z: [M-H] $]^{+}$Calcd. for $\mathrm{C}_{15} \mathrm{H}_{13} \mathrm{~F} 229.1034$; Found 229.1031

SFC with Chiralpak IA-3, 2.5\% iPrOH / 97.5\% CO $2,1.2 \mathrm{~mL} / \mathrm{min}, \mathrm{t}($ major, $(\mathbf{R})-6 \mathbf{e a})=9.12$ min., $\mathrm{t}($ minor, $(\mathbf{S})-6$ ea $)=9.12 \mathrm{~min}$.

Specific rotation: $[\alpha]_{\mathrm{D}}^{20}+25.5^{\circ}\left(\mathrm{c} 1.01, \mathrm{CHCl}_{3}\right)$ for an enantiomerically enriched sample of 98 : 2 er. The absolute configuration was assigned by analogy to (R)-3aa and it was not further verified.

\section{(R)-3-(4-chlorophenyl)-1-phenylpropan-1-ol (6fa)}

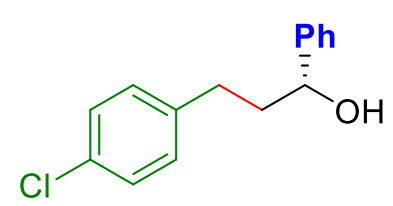

The compound $\mathbf{6 f a}$ was prepared according to General procedure 3 with $(R, R)-\mathbf{R u - 1}$ by reaction of 1-chloro-4vinylbenzene $(34.7 \mathrm{mg}, 0.25 \mathrm{mmol})$ with phenylboronic acid $(91.5 \mathrm{mg}, 0.75 \mathrm{mmol}$ ) and was isolated by column chromatography (silica gel, petroleum ether to petroleum ether/ethyl acetate $85: 15)$ to give white crystals, $\mathrm{mp}$ [66.8 $-67.3{ }^{\circ} \mathrm{C}$ ], in $77 \%$ yield (47.6 mg); NMR yield $81 \%$. 
${ }^{1} \mathbf{H}$ NMR $\left(500 \mathrm{MHz}, \mathrm{CDCl}_{3}\right) \delta 7.33-7.23(\mathrm{~m}, 4 \mathrm{H}), 7.23-7.12(\mathrm{~m}, 3 \mathrm{H}), 7.06-7.00(\mathrm{~m}$, $2 \mathrm{H}), 4.58(\mathrm{dd}, J=7.9,5.2 \mathrm{~Hz}, 1 \mathrm{H}), 2.68-2.51(\mathrm{~m}, 2 \mathrm{H}), 2.11-1.83(\mathrm{~m}, 2 \mathrm{H}), 1.72(\mathrm{~s}, 1 \mathrm{H})$. ${ }^{13} \mathbf{C}\left\{{ }^{1} \mathbf{H}\right\}$ NMR $\left(126 \mathrm{MHz}, \mathrm{CDCl}_{3}\right) \delta 144.5,140.3,131.7,129.9,128.7,128.6,127.9,126.0$, 73.8, 40.4, 31.5.

HRMS (ESI) m/z: [M-H] $]^{+}$Calcd. for $\mathrm{C}_{15} \mathrm{H}_{13} \mathrm{Cl} 245.0728$; Found 245.0725

SFC with Chiralpak ID-3, 5\% iPrOH / 95\% CO $1.2 \mathrm{~mL} / \mathrm{min}, \mathrm{t}$ (major, (R)-6fa) $=4.52$ min., $\mathrm{t}($ minor, $(\mathbf{S})-\mathbf{6 f a})=5.13 \mathrm{~min}$.

Specific rotation: $[\alpha]_{\mathrm{D}}{ }^{20}+17.3^{\circ}\left(\mathrm{c} 1.02, \mathrm{CHCl}_{3}\right)$ for an enantiomerically enriched sample of $97: 3$ er. The absolute configuration was assigned by analogy to (R)-3aa and it was not further verified.

\section{(R)-4-(3-hydroxy-3-phenylpropyl)phenyl acetate (6ga)}

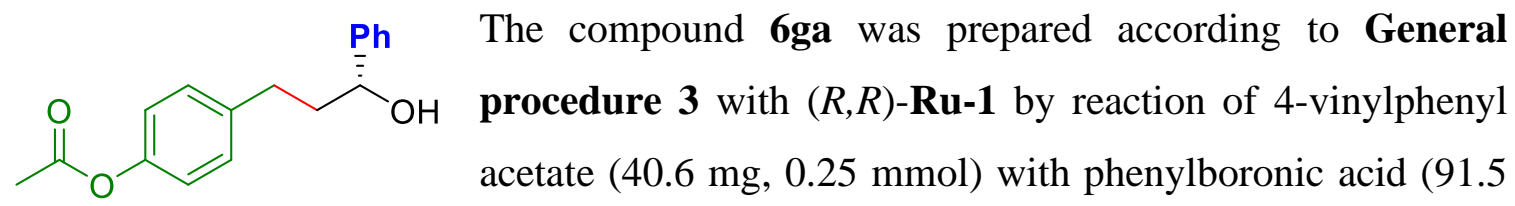

$\mathrm{mg}, 0.75 \mathrm{mmol}$ ) and was isolated by column chromatography (silica gel, petroleum ether to petroleum ether/ethyl acetate 60:40) to give a colorless oil in $84 \%$ yield (56.7 mg); NMR yield $90 \%$.

${ }^{1} \mathbf{H}$ NMR $\left(500 \mathrm{MHz}, \mathrm{CDCl}_{3}\right) \delta 7.40$ - $7.33(\mathrm{~m}, 4 \mathrm{H}), 7.33$ - $7.23(\mathrm{~m}, 1 \mathrm{H}), 7.22-7.16(\mathrm{~m}$, 2H), $7.04-6.95(\mathrm{~m}, 2 \mathrm{H}), 4.69(\mathrm{dd}, J=7.9,5.3 \mathrm{~Hz}, 1 \mathrm{H}), 2.80-2.56(\mathrm{~m}, 2 \mathrm{H}), 2.29(\mathrm{~s}, 3 \mathrm{H})$, $2.22-1.92(\mathrm{~m}, 2 \mathrm{H}), 1.83(\mathrm{~s}, 1 \mathrm{H})$.

${ }^{13} \mathbf{C}\left\{{ }^{1} \mathbf{H}\right\}$ NMR $\left(126 \mathrm{MHz}, \mathrm{CDCl}_{3}\right) \delta 169.8,148.9,144.6,139.5,129.5,128.7,127.9,126.1$, 121.5, 73.9, 40.5, 31.6, 21.3.

HRMS (ESI) m/z: [M+H-H $\left.\mathrm{H}_{2}\right]^{+}$Calcd. for $\mathrm{C}_{17} \mathrm{H}_{17} \mathrm{O}_{2}$ 253.1223; Found 253.1224.

SFC with Chiralpak IG-3, 10\% iPrOH / 90\% CO $2,1.2 \mathrm{~mL} / \mathrm{min}$, $\mathrm{t}$ (major, (R)-6ga) $=3.57$ min., $\mathrm{t}$ (minor, $(\mathbf{S})-\mathbf{6 g a})=4.06 \mathrm{~min}$.

Specific rotation: $[\alpha]_{\mathrm{D}}{ }^{20}+13.5^{\circ}\left(\mathrm{c} 0.99, \mathrm{CHCl}_{3}\right)$ for an enantiomerically enriched sample of $97: 3$ er. The absolute configuration was assigned by analogy to (R)-3aa and it was not further verified. 


\section{(R)-3-(3,5-bis(trifluoromethyl)phenyl)-1-phenylpropan-1-ol (6ha)}

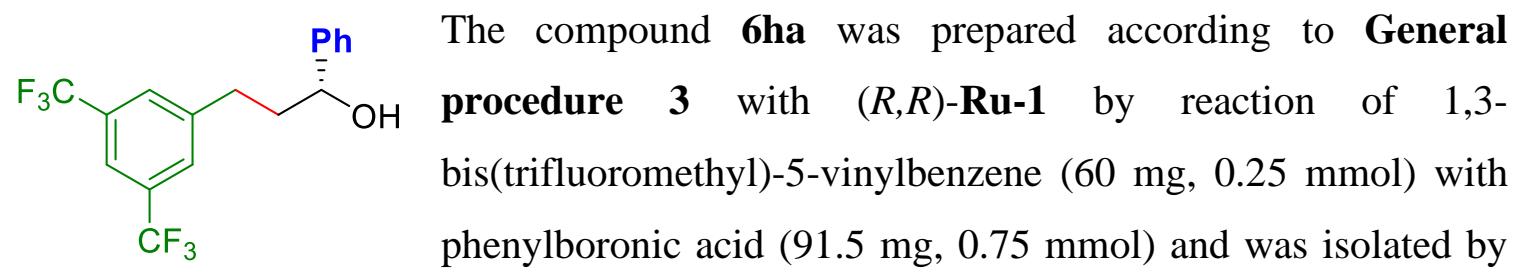

column chromatography (silica gel, petroleum ether to petroleum ether/ethyl acetate $85: 15$ ) to give colorless crystals, mp [41.3 $\left.-41.7{ }^{\circ} \mathrm{C}\right]$, in $66 \%$ yield $(57.7 \mathrm{mg})$; NMR yield $79 \%$. ${ }^{1} \mathbf{H}$ NMR $\left(500 \mathrm{MHz}, \mathrm{CDCl}_{3}\right) \delta 7.70(\mathrm{~s}, 1 \mathrm{H}), 7.63(\mathrm{~d}, J=1.7 \mathrm{~Hz}, 2 \mathrm{H}), 7.46-7.29(\mathrm{~m}, 5 \mathrm{H})$, $4.71(\mathrm{dd}, J=7.9,5.1 \mathrm{~Hz}, 1 \mathrm{H}), 3.02-2.66(\mathrm{~m}, 2 \mathrm{H}), 2.28-1.96(\mathrm{~m}, 2 \mathrm{H}), 1.88(\mathrm{~s}, 1 \mathrm{H})$.

${ }^{13} \mathbf{C}\left\{{ }^{1} \mathbf{H}\right\}$ NMR $\left(126 \mathrm{MHz}, \mathrm{CDCl}_{3}\right) \delta 144.3(\mathrm{~d}, J=37.1 \mathrm{~Hz}), 131.7(\mathrm{q}, J=33.0 \mathrm{~Hz}), 128.9$, 128.8 - $128.7(\mathrm{~m}), 128.2,126.0,123.6(\mathrm{~d}, J=272.5 \mathrm{~Hz}), 120.7$ - $119.6(\mathrm{~m}), 73.8,40.0$, 31.9 .

HRMS (ESI) m/z: [M+H-H $\left.\mathrm{H}_{2} \mathrm{O}\right]^{+}$Calcd. for $\mathrm{C}_{17} \mathrm{H}_{13} \mathrm{~F}_{6}$ 331.0916; Found 331.0916.

SFC with Chiralpak IB N-3, 2.5\% iPrOH / 97.5\% CO $1.2 \mathrm{~mL} / \mathrm{min}, \mathrm{t}$ (minor, (S)-6ha) $=$ $2.94 \mathrm{~min}$, $\mathrm{t}$ (major, $(\mathbf{R})-6 h a)=3.31 \mathrm{~min}$.

Specific rotation: $[\alpha]_{\mathrm{D}}{ }^{20}+23.2^{\circ}\left(\mathrm{c} 1.00, \mathrm{CHCl}_{3}\right)$ for an enantiomerically enriched sample of $97: 3$ er. The absolute configuration was assigned by analogy to (R)-3aa and it was not further verified.

\section{(R)-1-(4-methoxyphenyl)-5,5-dimethylhexan-1-ol (6ab)}

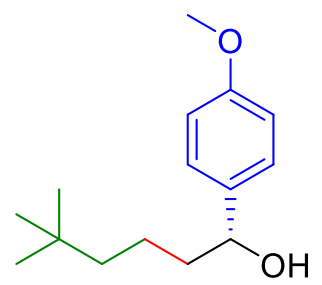

The compound $\mathbf{6 a b}$ was prepared according to General procedure 3 with $(R, R)$-Ru-1 by reaction of 4,4-dimethylpent-1-ene (24.6 mg, 0.25 mmol) with (4-methoxyphenyl)boronic acid (114 mg, $0.75 \mathrm{mmol}$ ) and was isolated by column chromatography (silica gel, petroleum ether to petroleum ether/ethyl acetate $85: 15$ ) to give a white solid, mp [59.1

$-59.5{ }^{\circ} \mathrm{C}$ ], in $76 \%$ yield (45.2 mg); NMR yield $84 \%$.

${ }^{1}$ H NMR $\left(500 \mathrm{MHz}, \mathrm{CDCl}_{3}\right) \delta 7.27(\mathrm{~d}, J=8.7 \mathrm{~Hz}, 2 \mathrm{H}), 6.88(\mathrm{~d}, J=8.7 \mathrm{~Hz}, 2 \mathrm{H}), 4.63(\mathrm{dd}$, $J=7.7,5.8 \mathrm{~Hz}, 1 \mathrm{H}), 3.81(\mathrm{~s}, 3 \mathrm{H}), 1.82-1.71(\mathrm{~m}, 2 \mathrm{H}), 1.71-1.60(\mathrm{~m}, 1 \mathrm{H}), 1.44-1.33$ (m, 1H), $1.30-1.15(\mathrm{~m}, 3 \mathrm{H}), 0.85(\mathrm{~s}, 9 \mathrm{H})$. 
${ }^{13} \mathbf{C}\left\{{ }^{1} \mathbf{H}\right\}$ NMR $\left(126 \mathrm{MHz}, \mathrm{CDCl}_{3}\right) \delta 159.0,137.2,127.1,113.8,74.3,55.3,44.1,40.0,30.4$, 29.4, 21.1.

HRMS (ESI) m/z: [M+H-H $\left.\mathrm{H}_{2} \mathrm{O}\right]^{+}$Calcd. for $\mathrm{C}_{15} \mathrm{H}_{23} \mathrm{O}$ 219.1743; Found 219.1742

SFC with Chiralpak ID-3, 2\% iPrOH / 98\% CO $2,1.2 \mathrm{~mL} / \mathrm{min}, \mathrm{t}($ major, $(\mathbf{R})-6 \mathbf{b b})=4.01$ min., $\mathrm{t}(\operatorname{minor},(\mathbf{S})-\mathbf{6 a b})=4.43 \mathrm{~min}$.

Specific rotation: $[\alpha]_{\mathrm{D}}^{20}+22.4^{\circ}\left(\mathrm{c} 0.98, \mathrm{CHCl}_{3}\right)$ for an enantiomerically enriched sample of $98: 2$ er. The absolute configuration was assigned by analogy to (R)-3ab and it was not further verified.

\section{(R)-5,5-dimethyl-1-(4-(methylthio)phenyl)hexan-1-ol (6ac)}

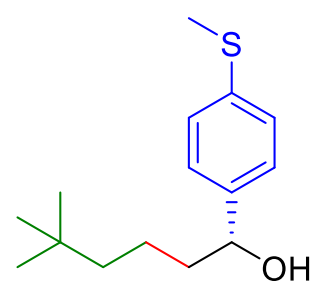

The compound 6ae was prepared according to General procedure 3 with $(R, R)$-Ru-1 by reaction of 4,4-dimethylpent-1-ene ( $24.6 \mathrm{mg}, 0.25$ mmol) with (4-(methylthio)phenyl)boronic acid ( $126 \mathrm{mg}, 0.75 \mathrm{mmol}$ ) and was isolated by column chromatography (silica gel, petroleum ether to petroleum ether/ethyl acetate 85:15) to give a white solid, mp [66.9 $-67.7^{\circ} \mathrm{C}$ ], in $84 \%$ yield $(53.1 \mathrm{mg})$; NMR yield $87 \%$.

${ }^{1} \mathbf{H}$ NMR $\left(500 \mathrm{MHz}, \mathrm{CDCl}_{3}\right) \delta 7.43-7.13(\mathrm{~m}, 4 \mathrm{H}), 4.64(\mathrm{dd}, J=7.8,5.6 \mathrm{~Hz}, 1 \mathrm{H}), 2.48(\mathrm{~s}$, $3 \mathrm{H}), 1.80-1.69(\mathrm{~m}, 2 \mathrm{H}), 1.69-1.59(\mathrm{~m}, 1 \mathrm{H}), 1.44-1.33(\mathrm{~m}, 1 \mathrm{H}), 1.30-1.10(\mathrm{~m}, 3 \mathrm{H})$, $0.85(\mathrm{~s}, 9 \mathrm{H})$.

${ }^{13} \mathbf{C}\left\{{ }^{1} \mathbf{H}\right\}$ NMR $\left(126 \mathrm{MHz}, \mathrm{CDCl}_{3}\right) \delta 142.0,137.4,126.8,126.5,74.3,44.0,40.0,30.4,29.4$, 21.0, 16.0.

HRMS (ESI) m/z: [M+H-H $\left.\mathrm{H}_{2} \mathrm{O}\right]^{+}$Calcd. for $\mathrm{C}_{15} \mathrm{H}_{23} \mathrm{~S}$ 235.1515; Found 235.1515

SFC with Chiralpak IC-3, 5\% iPrOH / 95\% CO $2,1.2 \mathrm{~mL} / \mathrm{min}, \mathrm{t}($ major, $(\mathbf{R})-6 \mathrm{cac})=4.76$ min., $\mathrm{t}(\operatorname{minor},(\mathbf{S})-\mathbf{6 a c})=5.85 \mathrm{~min}$.

Specific rotation: $[\alpha]_{\mathrm{D}}{ }^{20}+21.8^{\circ}\left(\mathrm{c} 0.98, \mathrm{CHCl}_{3}\right)$ for an enantiomerically enriched sample of $96: 4$ er. The absolute configuration was assigned by analogy to (R)-3ab and it was not further verified. 


\section{(R)-1-(4-fluorophenyl)-5,5-dimethylhexan-1-ol (6ad)}

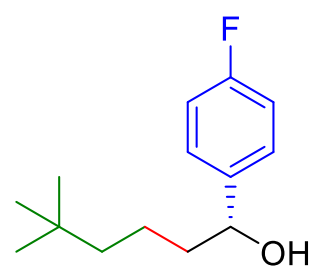

The compound $\mathbf{6 a g}$ was prepared according to General procedure 3 with $(R, R)$-Ru-1 by reaction of 4,4-dimethylpent-1-ene (24.6 mg, 0.25 mmol) with (4-fluorophenyl)boronic acid (105 $\mathrm{mg}, 0.75 \mathrm{mmol})$ and was isolated by column chromatography (silica gel, petroleum ether to petroleum ether/ethyl acetate $85: 15$ ) to give a white solid, mp [69.7-70.4 ${ }^{\circ} \mathrm{C}$ ], in $73 \%$ yield (41.2 mg); NMR yield $85 \%$.

${ }^{1} \mathbf{H}$ NMR $\left(500 \mathrm{MHz}, \mathrm{CDCl}_{3}\right) \delta 7.28-7.20(\mathrm{~m}, 2 \mathrm{H}), 7.00-6.90(\mathrm{~m}, 2 \mathrm{H}), 4.60(\mathrm{dd}, J=7.8$, $5.6 \mathrm{~Hz}, 1 \mathrm{H}), 1.73-1.62(\mathrm{~m}, 2 \mathrm{H}), 1.61-1.51(\mathrm{~m}, 1 \mathrm{H}), 1.37-1.25(\mathrm{~m}, 1 \mathrm{H}), 1.23-1.07$ $(\mathrm{m}, 3 \mathrm{H}), 0.78(\mathrm{~s}, 9 \mathrm{H})$.

${ }^{13} \mathbf{C}\left\{{ }^{1} \mathbf{H}\right\}$ NMR $\left(126 \mathrm{MHz}, \mathrm{CDCl}_{3}\right) \delta 162.1(\mathrm{~d}, J=245.1 \mathrm{~Hz}), 140.7(\mathrm{~d}, J=3.1 \mathrm{~Hz}), 127.5$ $(\mathrm{d}, J=8.0 \mathrm{~Hz}), 115.2(\mathrm{~d}, J=21.3 \mathrm{~Hz}), 74.1(\mathrm{~d}, J=0.6 \mathrm{~Hz}), 44.0,40.1(\mathrm{~d}, J=0.8 \mathrm{~Hz}), 30.4$, 29.4, 20.9 .

${ }^{19}$ F NMR (471 MHz, $\left.\mathrm{CDCl}_{3}\right) \delta-115.28(\mathrm{q}, J=7.5,5.4 \mathrm{~Hz})$.HRMS (ESI) m/z: [M+H$\left.\mathrm{H}_{2} \mathrm{O}\right]^{+}$Calcd. for $\mathrm{C}_{14} \mathrm{H}_{20} \mathrm{~F} 207.1544$; Found 207.1545

SFC with Chiralpak IG-3, 5\% iPrOH / 95\% CO $2,1.2 \mathrm{~mL} / \mathrm{min}, \mathrm{t}(\operatorname{minor},(\mathbf{S})-\mathbf{6 a d})=1.81$ min., $\mathrm{t}($ major, $(\mathbf{R})-\mathbf{6 a d})=1.95 \mathrm{~min}$.

Specific rotation: $[\alpha]_{\mathrm{D}}{ }^{20}+23.7^{\circ}\left(\mathrm{c} 1.00, \mathrm{CHCl}_{3}\right)$ for an enantiomerically enriched sample of $98: 2$ er. The absolute configuration was assigned by analogy to (R)-3aa and it was not further verified.

\section{(R)-5,5-dimethyl-1-(m-tolyl)hexan-1-ol (6ae)}

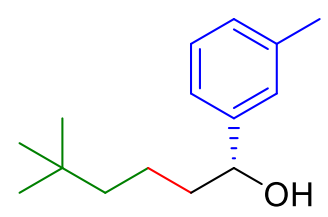

The compound 6ak was prepared according to General procedure 3 with $(R, R)$-Ru-1 by reaction of 4,4-dimethylpent-1-ene $(24.6 \mathrm{mg}$, $0.25 \mathrm{mmol})$ with $m$-tolylboronic acid $(102 \mathrm{mg}, 0.75 \mathrm{mmol})$ and was isolated by column chromatography (silica gel, petroleum ether to petroleum ether/ethyl acetate $85: 15$ ) to give a colorless oil in $87 \%$ yield (48.1 mg); NMR yield $91 \%$. 
${ }^{1} \mathbf{H}$ NMR $\left(500 \mathrm{MHz}, \mathrm{CDCl}_{3}\right) \delta 7.16(\mathrm{t}, J=7.5 \mathrm{~Hz}, 1 \mathrm{H}), 7.09(\mathrm{~s}, 1 \mathrm{H}), 7.08-6.98(\mathrm{~m}, 2 \mathrm{H})$, $4.57(\mathrm{dd}, J=8.0,5.3 \mathrm{~Hz}, 1 \mathrm{H}), 2.29(\mathrm{~s}, 3 \mathrm{H}), 1.88-1.64(\mathrm{~m}, 2 \mathrm{H}), 1.62-1.52(\mathrm{~m}, 1 \mathrm{H}), 1.43$ - $1.28(\mathrm{~m}, 1 \mathrm{H}), 1.28-1.02(\mathrm{~m}, 3 \mathrm{H}), 0.79(\mathrm{~s}, 9 \mathrm{H})$.

${ }^{13} \mathbf{C}\left\{{ }^{1} \mathbf{H}\right\}$ NMR $\left(126 \mathrm{MHz}, \mathrm{CDCl}_{3}\right) \delta 145.2,138.2,128.5,128.3,126.7,123.0,74.8,44.2$, $40.2,30.5,29.5,21.6,21.2$.

HRMS (ESI) m/z: [M+H-H $\left.{ }_{2} \mathrm{O}\right]^{+}$Calcd. for $\mathrm{C}_{15} \mathrm{H}_{23}$ 203.1794; Found 203.1795

SFC with Chiralpak ID-3, 5\% iPrOH / 95\% CO $2,1.2 \mathrm{~mL} / \mathrm{min}$, $\mathrm{t}$ (major, $(\mathbf{R})-6 \mathbf{a e})=1.29$ min., $\mathrm{t}(\operatorname{minor},(\mathbf{S})-\mathbf{6 a e})=1.48 \mathrm{~min}$.

Specific rotation: $[\alpha]_{\mathrm{D}}^{20}+22.9^{\circ}\left(\mathrm{c} 0.71, \mathrm{CHCl}_{3}\right)$ for an enantiomerically enriched sample of $98: 2$ er. The absolute configuration was assigned by analogy to (R)-3ak and it was not further verified.

\section{(R)-1-(3-chlorophenyl)-5,5-dimethylhexan-1-ol (6af)}

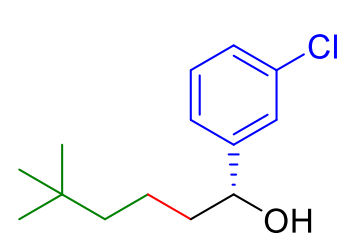

The compound 6al was prepared according to General procedure 3 with $(R, R)-\mathbf{R u}-\mathbf{1}$ by reaction of 4,4-dimethylpent-1-ene $(24.6 \mathrm{mg}$, $0.25 \mathrm{mmol}$ ) with (3-chlorophenyl)boronic acid (117.28 $\mathrm{mg}, 0.75$

mmol) and was isolated by column chromatography (silica gel, petroleum ether to petroleum ether/ethyl acetate 85:15) to give a colorless oil in $75 \%$ yield (45.3 mg); NMR yield $80 \%$.

${ }^{1} \mathbf{H}$ NMR $\left(500 \mathrm{MHz}, \mathrm{CDCl}_{3}\right) \delta 7.42-7.32(\mathrm{~m}, 1 \mathrm{H}), 7.31-7.18(\mathrm{~m}, 3 \mathrm{H}), 4.67$ (dd, J = 7.9, $5.3 \mathrm{~Hz}, 1 \mathrm{H}), 1.95-1.70(\mathrm{~m}, 2 \mathrm{H}), 1.69-1.54(\mathrm{~m}, 1 \mathrm{H}), 1.47-1.34(\mathrm{~m}, 1 \mathrm{H}), 1.33-1.09$ (m, 3H), $0.86(\mathrm{~s}, 9 \mathrm{H})$.

${ }^{13} \mathbf{C}\left\{{ }^{1} \mathbf{H}\right\}$ NMR $\left(126 \mathrm{MHz}, \mathrm{CDCl}_{3}\right) \delta 147.2,134.5,129.8,127.7,126.2,124.1,74.2,44.1$, $40.2,30.5,29.5,21.0$.

HRMS (ESI) m/z: [M+H-H $\left.{ }_{2} \mathrm{O}\right]^{+}$Calcd. for $\mathrm{C}_{14} \mathrm{H}_{20} \mathrm{Cl} 223.1248$; Found 223.1246

SFC with Chiralpak IA-3, 5\% iPrOH / 95\% $\mathrm{CO}_{2}, 1.2 \mathrm{~mL} / \mathrm{min}$, $\mathrm{t}$ (major, (R)-6af) $=2.53$ min., $\mathrm{t}($ minor, $(\mathbf{S})-\mathbf{6 a f})=2.85 \mathrm{~min}$.

Specific rotation: $[\alpha]_{\mathrm{D}}{ }^{20}+16.8^{\circ}\left(\mathrm{c} 1.00, \mathrm{CHCl}_{3}\right)$ for an enantiomerically enriched sample of 95 : 5 er. The absolute configuration was assigned by analogy to (R)-3ak and it was not further verified. 


\section{(R)-5,5-dimethyl-1-(naphthalen-2-yl)hexan-1-ol (6ag)}

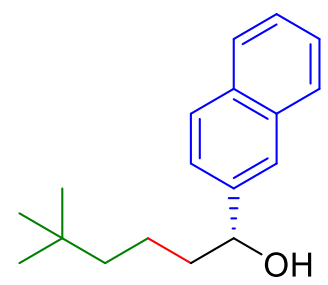

The compound 6ar was prepared according to General procedure 3 with $(R, R)-\mathbf{R u}-\mathbf{1}$ by reaction of 4,4-dimethylpent-1-ene $(24.6 \mathrm{mg}$, $0.25 \mathrm{mmol})$ with naphthalen-2-ylboronic acid (129 $\mathrm{mg}, 0.75 \mathrm{mmol})$ and was isolated by column chromatography (silica gel, petroleum ether to petroleum ether/ethyl acetate $85: 15$ ) to give a white solid in $78 \%$ yield (49.8 mg); NMR yield $90 \%$.

${ }^{1} \mathbf{H}$ NMR $\left(500 \mathrm{MHz}, \mathrm{CDCl}_{3}\right) \delta 7.87-7.80(\mathrm{~m}, 3 \mathrm{H}), 7.80-7.77(\mathrm{~m}, 1 \mathrm{H}), 7.55-7.42(\mathrm{~m}$, $3 \mathrm{H}), 4.86(\mathrm{dd}, J=7.7,5.5 \mathrm{~Hz}, 1 \mathrm{H}), 1.94-1.82(\mathrm{~m}, 2 \mathrm{H}), 1.81-1.66(\mathrm{~m}, 1 \mathrm{H}), 1.61-1.37$ $(\mathrm{m}, 1 \mathrm{H}), 1.37-1.16(\mathrm{~m}, 3 \mathrm{H}), 0.86(\mathrm{~s}, 9 \mathrm{H})$.

${ }^{13} \mathbf{C}\left\{{ }^{1} \mathbf{H}\right\}$ NMR $\left(126 \mathrm{MHz}, \mathrm{CDCl}_{3}\right) \delta 142.5,133.4,133.1,128.4,128.1,127.8,126.2,125.9$, $124.7,124.2,74.9,44.2,40.1,30.5,29.5,21.2$.

HRMS (ESI) m/z: [M+H-H $2 \mathrm{O}]^{+}$Calcd. for $\mathrm{C}_{18} \mathrm{H}_{23}$ 239.1794; Found 239.1792

SFC with Chiralpak ID-3, 5\% iPrOH / 95\% CO $2,1.2 \mathrm{~mL} / \mathrm{min}, \mathrm{t}$ (major, $(\mathbf{R})-\mathbf{6 a g})=3.05$ min., $\mathrm{t}($ minor, $(\mathbf{S})-\mathbf{6 a r})=3.43 \mathrm{~min}$.

Specific rotation: $[\alpha]_{\mathrm{D}}{ }^{20}+21.9^{\circ}\left(\mathrm{c} 0.53, \mathrm{CHCl}_{3}\right)$ for an enantiomerically enriched sample of $97: 3$ er. The absolute configuration was assigned by analogy to (R)-3ag and it was not further verified. 


\section{COMPARISON OF ONE-POT AND STEPWISE SYNTHESIS OF ENANTIOMERICALLY ENRICHED 5,5-DIMETHYL-1-PHENYLHEXAN-1-OL}

\section{Stepwise synthesis of (S)-5,5-dimethyl-1-phenylhexan-1-ol ((S)-6aa)}
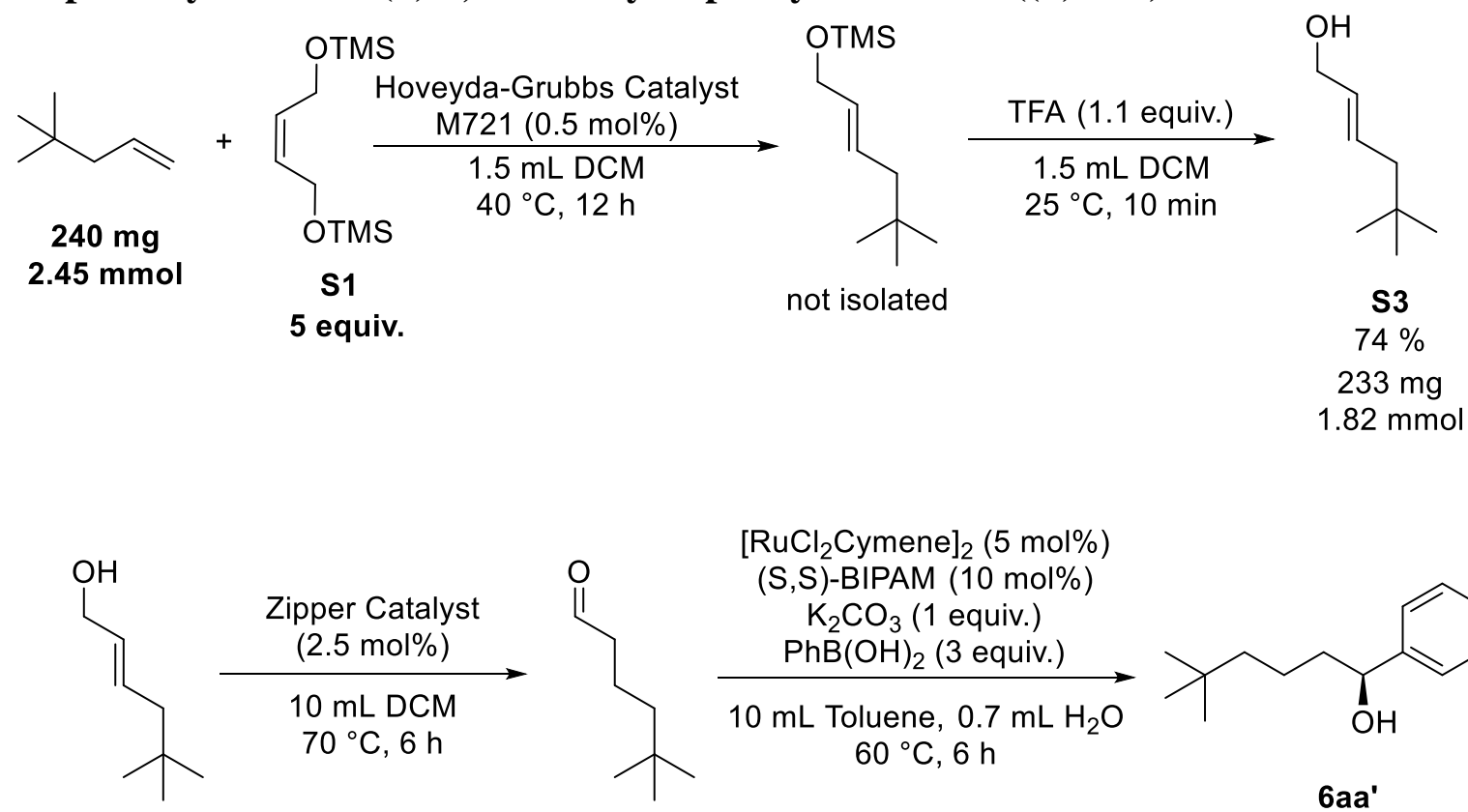

$\left[\mathrm{RuCl}_{2} \text { Cymene }\right]_{2}(5 \mathrm{~mol} \%)$
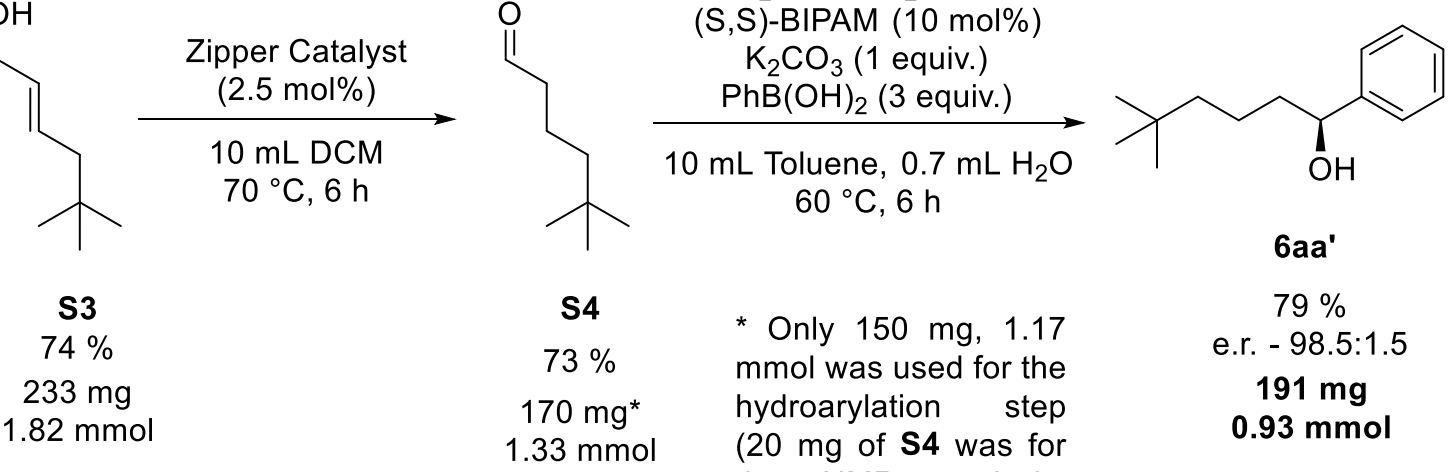

* Only 150 mg, 1.17 mmol was used for the hydroarylation step (20 mg of S4 was for the NMR analysis, which was not recovered due to the volatility of the compound)

Table S3

\begin{tabular}{|c|c|c|c|}
\hline Step & $\begin{array}{c}\text { Solvents used } \\
\text { stepwise approach }\end{array}$ & Step & $\begin{array}{c}\text { Solvents used one- } \\
\text { pot approach }\end{array}$ \\
\hline $\begin{array}{c}\text { Cross-Metathesis }+ \\
\text { deprotection }\end{array}$ & $1.4 \mathrm{~L}$ & One-pot sequence & $1.8 \mathrm{~L}$ \\
\hline Isomerization & $1.5 \mathrm{~L}$ & & $\mathbf{1 . 8 ~ L}$ \\
\hline Hydroarylation & $1.8 \mathrm{~L}$ & Total & \\
\hline Total & $\mathbf{4 . 7} \mathbf{L}$ & &
\end{tabular}

\section{Table S4}

\begin{tabular}{|c|c|c|c|}
\hline Step & $\begin{array}{c}\text { Yield of isolated } \\
\text { material } \\
\text { (Analytical yield) }\end{array}$ & Step & $\begin{array}{c}\text { Yield of isolated } \\
\text { material } \\
\text { (Analytical yield) }\end{array}$ \\
\hline $\begin{array}{c}\text { Cross-Metathesis }+ \\
\text { deprotection }\end{array}$ & $\begin{array}{c}74 \%(>95 \% \text { by GC } \\
\text { analysis) }\end{array}$ & One-pot sequence & $\begin{array}{c}77 \%\left(86 \% \text { by }{ }^{1} \mathrm{H}\right. \\
\text { NMR analysis })\end{array}$ \\
\hline
\end{tabular}




\begin{tabular}{|c|c|c|c|}
\hline Isomerization & $\begin{array}{c}73 \%(>90 \% \\
\text { conversion by } \mathrm{GC} \\
\text { analysis) }\end{array}$ & & \\
\cline { 1 - 2 } Hydroarylation & $\begin{array}{c}79 \%\left(81 \% \text { by }{ }^{1} \mathrm{H}\right. \\
\text { NMR analysis })\end{array}$ & & \\
\hline Total & $\mathbf{4 3 \%}$ & Total & $\mathbf{7 7 \%}$ \\
\hline
\end{tabular}

\section{(E)-5,5-Dimethylhex-2-en-1-ol (S3)}

In a nitrogen filled glovebox, a $20 \mathrm{~mL}$ vial equipped with an octagonal stirring bar $(20 \mathrm{~mm}$ x $5 \mathrm{~mm}$ ) was charged with 5,5-dimethylpent-1-ene (240 mg, $2.44 \mathrm{mmol}, 1.00$ equiv) and bis-TMS protected (Z)-but-2-ene-1,4-diol (2.84 g, 5.00 equiv, $12.2 \mathrm{mmol}$ ). Next, a solution of Hoveyda-Grubbs catalyst M721 (0.0050 equiv, $7.0 \mathrm{mg}, 0.012 \mathrm{mmol}$ in $1 \mathrm{~mL}$ DCM) was added. The vial was sealed with a Teflon-lined screw cap, and the reaction mixture was allowed to stir at $800 \mathrm{rpm}$ at $40{ }^{\circ} \mathrm{C}$ for $12 \mathrm{~h}$. After that, the vial was removed from the heating block and let to cool to room temperature. A degassed solution of trifluoroacetic acid in water $(40 \% \mathrm{v} / \mathrm{v} ; 1 \mathrm{~mL})$ was added, the vial was sealed, shaken, and let to stir vigorously for $10 \mathrm{~min}$. A degassed saturated water solution of $\mathrm{NaHCO}_{3}(5 \mathrm{~mL})$ was added, and the mixture was allowed to stir for 10 min with free evolution of $\mathrm{CO}_{2}$. DCM (4 mL) was added to the mixture, the vial was sealed and shaken. Upon phase separation, the bottom organic layer was transferred to a new vial with the aid of a syringe equipped with a needle. The aqueous phase was washed additionally with DCM $(4 \mathrm{~mL})$. The organic fractions were combined, dried over anhydrous $\mathrm{Na}_{2} \mathrm{SO}_{4}(3 \mathrm{~g})$ and filtered. (The yield was measured by GC-FID analysis using dodecane as an internal standards). The volatiles from the filtrate were removed under reduced pressure. The residue was subjected to column chromatography on silica gel ( $40 \mathrm{~g})$, conducted with the aid of a Combiflash instrument, using a gradient of $\mathrm{Et}_{2} \mathrm{O}: \mathrm{DCM}$ (0:100 to 10:90). The fractions containing the product (based on GC-MS and/or TLC) were combined. The solvent was carefully evaporated under reduced pressure to yield the product as a volatile, colourless liquid in $74 \%$ yield (233 $\mathrm{mg}, 1.82 \mathrm{mmol}$ ). The NMR data match previously reported data for the title compound. ${ }^{14}$

${ }^{1} \mathbf{H}$ NMR (500 MHz, CDCl $) \delta 5.77-5.67(\mathrm{~m}, 1 \mathrm{H}), 5.70-5.57(\mathrm{~m}, 1 \mathrm{H}), 4.11(\mathrm{dd}, J=$ 5.8, $1.1 \mathrm{~Hz}, 2 \mathrm{H}), 1.93$ (dd, $J=7.3,1.1 \mathrm{~Hz}, 2 \mathrm{H}), 1.33$ (bs, 1H), 0.88 (s, 9H). 


\section{5,5-Dimethylhexanal (S4)}

In a nitrogen-filled glovebox, a $20 \mathrm{~mL}$ vial equipped with an octagonal stirring bar ( $20 \mathrm{~mm}$ x $5 \mathrm{~mm}$ ) was charged with (E)-5,5-Dimethylhex-2-en-1-ol (S1) (233 mg, $1.82 \mathrm{mmol})$. Next a solution of Alkene Zipper catalyst Ru-2 (acetonitrile(cyclopentadienyl)[2-(di- $i$ propylphosphino)-4-( $t$-butyl)-1-methyl-1 $H$-imidazole]ruthenium(II)hexafluorophosphate; 0.025 equiv, $27.6 \mathrm{mg}, 0.045 \mathrm{mmol}$ in $10 \mathrm{~mL}$ DCM) was added. The vial was sealed with a Teflon-lined screw cap, and the reaction mixture was allowed to stir at $800 \mathrm{rpm}$ for $6 \mathrm{~h}$ at $70{ }^{\circ} \mathrm{C}$. Upon cooling to room temperature, the mixture was concentrated to $\sim 0.3-0.5 \mathrm{~mL}$. The remaining liquid was subjected to flash chromatography on silica $(40 \mathrm{~g})$, conducted with the aid of a Combiflash instrument, using a gradient of DCM:n-pentane (0:100 to 50:50). The fractions containing the product (based on GC-MS and/or TLC) were combined and filtered through a short plug of neutral alumina, ${ }^{*}$ filtered through a Tefloncoated syringe filter, and carefully concentrated under reduced pressure to yield the product as a volatile, colourless liquid in $73 \%$ yield (170 $\mathrm{mg}, 1.33 \mathrm{mmol})$. The product should be stored under inert atmosphere. (Full decomposition was observed overnight when stored under air at room temperature). The NMR data match previously reported data for the title compound. ${ }^{13}$

*We noted that it was crucial to filter 5,5-dimethylhexan-1-al through a plug of neutral alumina for the subsequent reaction. If this step was omitted, the hydroarylation reaction did not occur.

${ }^{1} \mathbf{H}$ NMR $\left(\mathbf{5 0 0} \mathbf{M H z}, \mathbf{C D C l}_{3}\right) \delta 9.77(\mathrm{t}, J=1.8 \mathrm{~Hz}, 1 \mathrm{H}), 2.40(\mathrm{td}, J=7.4,1.8 \mathrm{~Hz}, 2 \mathrm{H})$, $1.65-1.56(\mathrm{~m}, 2 \mathrm{H}), 1.22-1.16(\mathrm{~m}, 2 \mathrm{H}), 0.89(\mathrm{~s}, 9 \mathrm{H})$.

\section{(S)-5,5-Dimethyl-1-phenylhexan-1-ol (6aa)}

Under inert conditions of a nitrogen-filled glovebox, in a $20 \mathrm{~mL}$ vial equipped with a 20 $\mathrm{mm} \times 5 \mathrm{~mm}$ stirring bar, a solution of $\left[\mathrm{Ru}[\mathrm{cymene}] \mathrm{Cl}_{2}\right]_{2}(0.005$ equiv, $38 \mathrm{mg}, 0.060 \mathrm{mmol})$ and $(\mathrm{S}, \mathrm{S})$-BIPAM $(0.10$ equiv, $95 \mathrm{mg}, 0.12 \mathrm{mmol})$ in toluene $(10 \mathrm{~mL})$ was allowed to stir for $30 \mathrm{~min}$ at room temperature. In order, 5,5-dimethylhexanal* (150 mg, $1.17 \mathrm{mmol}$ ), a degassed aqueous solution of $\mathrm{K}_{2} \mathrm{CO}_{3}(1.8 \mathrm{M}, 0.70 \mathrm{~mL}, 1.0$ equiv), and phenyl boronic acid (456 mg, 3.00 equiv, $3.75 \mathrm{mmol}$ ) were added. The vial was sealed with a Teflon-coated cap, and the reaction mixture was allowed to stir with $800 \mathrm{rpm}$ at $60{ }^{\circ} \mathrm{C}$ for $6 \mathrm{~h}$. After 
cooling to room temperature, the reaction mixture was diluted with DCM $(20 \mathrm{~mL})$. (The yield was measured by GC-MS and/or NMR analysis using dodecane or 1,3,5trimethoxybenezene as an internal standards). Celite (10 g) was added to the reaction mixture, and the volatile were removed under reduced pressure. The solid residue was subjected to column chromatography on silica gel (40 g), conducted with the aid of a Combiflash instrument, using a gradient of petroleum ether and ethyl acetate (100:0 to $85: 15$ ) as the eluent. Fractions containing the pure product (judged by the TLC and/or GC analyses) were combined, and the solvent was evaporated, yielding product 6aa (191 mg, $0.93 \mathrm{mmol}, 79 \%$ yield) as a yellowish solid. The NMR data match the above-described data for compound 6aa. The enantiomeric ratio in the isolated material was determined to be $98.5: 1.5$.

*We noted that it was crucial to filter 5,5-dimethylhexan-1-al through a plug of neutral alumina. If this step was omitted, the hydroarylation reaction did not occur.

\section{One-pot synthesis of (S)-5,5-dimethyl-1-phenylhexan-1-ol ((S)-6aa)}

All following operations were performed in the nitrogen-filled glovebox. A $20 \mathrm{ml}$ vial equipped with a stirring bar $(20 \mathrm{~mm} \times 5 \mathrm{~mm})$ was charged with 5,5-dimethylpent-1-ene (240 mg, $2.44 \mathrm{mmol}, 1.0$ equiv), bis-TMS protected Z-butenodiol (S1, $2.84 \mathrm{~g}, 12.2 \mathrm{mmol}$, 5 equiv), and a solution of Hoveyda-Grubbs Catalyst ${ }^{\circledR}$ M721 (7.0 mg, 0.005 equiv, 0.012 mmol in $1 \mathrm{~mL}$ of DCM). Next, the vial was sealed with a Teflon-lined screw cap, placed in a preheated aluminum block at $40{ }^{\circ} \mathrm{C}$, and allowed to stir at $800 \mathrm{rpm}$ for $12 \mathrm{~h}$. After that, the vial was removed from the heating block and let to cool to room temperature. A degassed solution of trifluoroacetic acid in water $(40 \% \mathrm{v} / \mathrm{v} ; 1 \mathrm{~mL})$ was added, the vial was sealed, shaken, and let to stir vigorously for $10 \mathrm{~min}$. A degassed saturated water solution of $\mathrm{NaHCO}_{3}(5 \mathrm{~mL})$ was added, and the mixture was allowed to stir for $10 \mathrm{~min}$ with free evolution of $\mathrm{CO}_{2}$. The reaction mixture was diluted with DCM $(6 \mathrm{~mL})$, the vial was sealed and shaken. Upon phase separation, the bottom organic layer was transferred to a new vial with the aid of a $10 \mathrm{~mL}$ syringe equipped with a needle. The aqueous phase was washed additionally with DCM $(6 \mathrm{~mL})$. Then combined organic fractions were dried over anhydrous $\mathrm{Na}_{2} \mathrm{SO}_{4}(3 \mathrm{~g})$, filtered, and the volatiles from the filtrate were removed under reduced pressure. The solution of Alkene Zipper catalyst Ru-2 
(acetonitrile(cyclopentadienyl)[2-(di-i-propylphosphino)-4-( $t$-butyl)-1-methyl-1Himidazole]ruthenium(II) hexafluorophosphate; $38 \mathrm{mg}, 0.025 \mathrm{mmol}, 0.061 \mathrm{mmol}$ in $5 \mathrm{ml}$ DCM) was added, and the mixture was allowed to stir at $70{ }^{\circ} \mathrm{C}$ for $6 \mathrm{~h}$. (In the meantime, a stock solution of Ru-1 was prepared by allowing to stir a mixture of $\left[\mathrm{Ru}\left(\mathrm{p} \text {-cymene) } \mathrm{Cl}_{2}\right]_{2}\right.$ (73 mg, 0.05 equiv, $0.12 \mathrm{mmol}$ ) and (S,S)-BIPAM (0.1 equiv, $186 \mathrm{mg}, 0.24 \mathrm{mmol})$ in toluene $(20 \mathrm{~mL})$ for $0.5 \mathrm{~h}$ at $\mathrm{rt})$. After cooling to room temperature, the reaction mixture was transferred to an oven-dried $100 \mathrm{~mL}$ round-bottom flask. Then, the solution of Ru-1, the aqueous solution of $\mathrm{K}_{2} \mathrm{CO}_{3}(1.5 \mathrm{~mL}, 1.6 \mathrm{M}, 1$ equiv), and phenylboronic acid ( $893 \mathrm{mg}$, $7.32 \mathrm{mmol}, 3$ equiv,) were added to the reaction mixture. The flask was sealed with a Teflon-lined cap, removed from the glovebox, placed in a preheated oil bath at $60{ }^{\circ} \mathrm{C}$, and allowed to stir at $800 \mathrm{rpm}$ for $6 \mathrm{~h}$. After cooling to room temperature, the reaction mixture was diluted with DCM $(20 \mathrm{~mL})$. (The yield was measured by NMR analysis using dodecane or 1,3,5-trimethoxybenezene as an internal standards). Celite (10 g) was added, and the volatile were removed under reduced pressure. The solid residue was subjected to column chromatography on silica gel $(40 \mathrm{~g})$, conducted with the aid of a Combiflash instrument, using a gradient of petroleum ether and ethyl acetate (100:0 to 85:15) as the eluent. Fractions containing the pure product (judged by the TLC and/or GC analyses) were combined, and the solvent was evaporated, yielding product 6aa (389 mg, $1.89 \mathrm{mmol}, 77 \%$ yield) as a yellowish solid. The NMR data match the above-described data for compound 6aa. The enantiomeric ratio in the isolated material was determined to be $96: 4$. 


\section{ENANTIOSELECTIVE ISOMERIZATION AND ARYLATION OF PROCHIRAL ALLYLIC ALCOHOLS}

\section{A. Optimization of the Reaction Conditions and Control Experiments}

Typical procedure: In a nitrogen-filled glovebox, an oven-dried $4 \mathrm{~mL}$ screw-cap scintillation vial equipped with an octagonal stir bar $(2 \mathrm{~mm}$ x $5 \mathrm{~mm}$ ) was charged with (E)3,7-dimethylocta-2,6-dien-1-ol ( $27 \mu \mathrm{L}, 0.25 \mathrm{mmol}, 1$ equiv), $\mathrm{K}_{2} \mathrm{CO}_{3}$ ( $3.5 \mathrm{mg}, 0.10$ equiv), Ru-3, and degassed ethanol. Next, the vial was sealed with a Teflon-lined screw cap and the solution was allowed to stir at the indicated temperature for the indicated time. The reaction mixture was then analyzed with the aid of GC-MS equipment. Yields were measured by GC-MS analysis using 1,3,5-trimethoxybenezene as an internal standard.

The initial experiments indicated that the step of enantioselective isomerization of prochiral allylic alcohols occurs selectively in protic solvents $(\mathrm{EtOH}, \mathrm{MeOH})$, while the arylation steps occurs selectively in aromatic solvents (toluene, xylene). With the aim of avoiding the need for exchange of the solvent between the isomerization and arylations steps, the experiments were performed in order to identify conditions for the isomerization with the minimal amount of solvent, which would be compatible with the arylation step (upon dilution with aromatic solvent) - Figures S1-S4. However, the high reaction concentration resulted in unselective isomerization with formation of substantial amounts of sideproducts. Overall, the highest-yielding reactions were performed with $0.2 \mathrm{M}$ solution of the starting material $(0.25 \mathrm{mmol}$ of (E)-3,7-dimethylocta-2,6-dien-1-ol in $1.25 \mathrm{~mL}$ of $\left.\mathrm{EtOH}^{*}\right), 10 \mathrm{~mol} \%$ of $\mathrm{K}_{2} \mathrm{CO}_{3}$, and $2 \mathrm{~mol} \%$ of Ru-3. Under these conditions, formation of byproducts was suppressed, and the aldehyde intermediate was formed in $85 \%$ yield.

* Reactions performed in $\mathrm{MeOH}$ afforded the product in similar yields, but the reproducibility of these reactions was lower than those in EtOH. 
Figure S1. Isomerization of (E)-3,7-dimethylocta-2,6-dien-1-ol - influence of time and temperature.
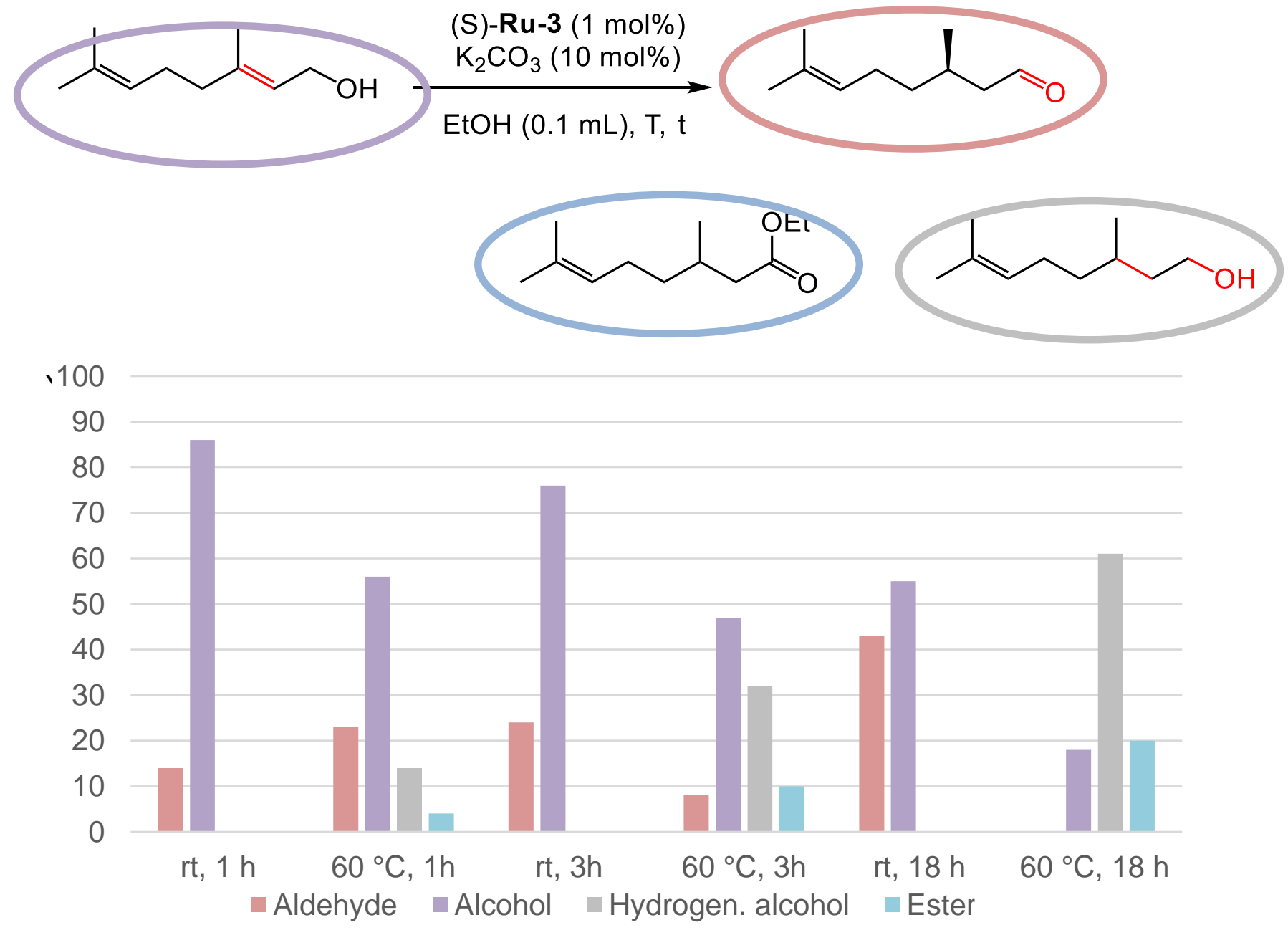
Figure S2. Isomerization of (E)-3,7-dimethylocta-2,6-dien-1-ol - influence of temperature and catalyst loading.

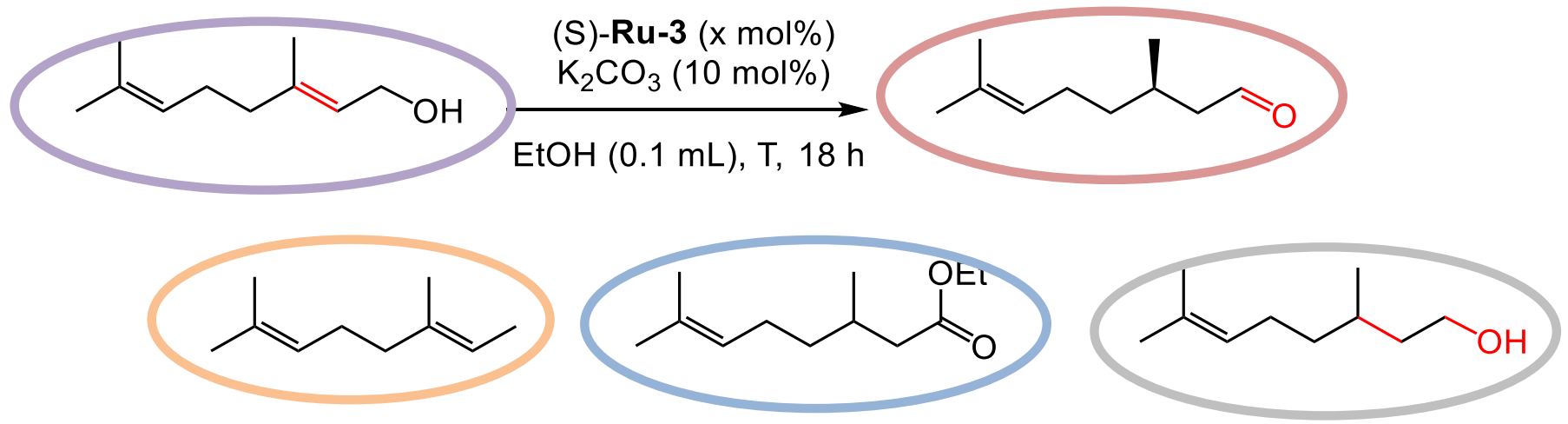

Yield (\%)

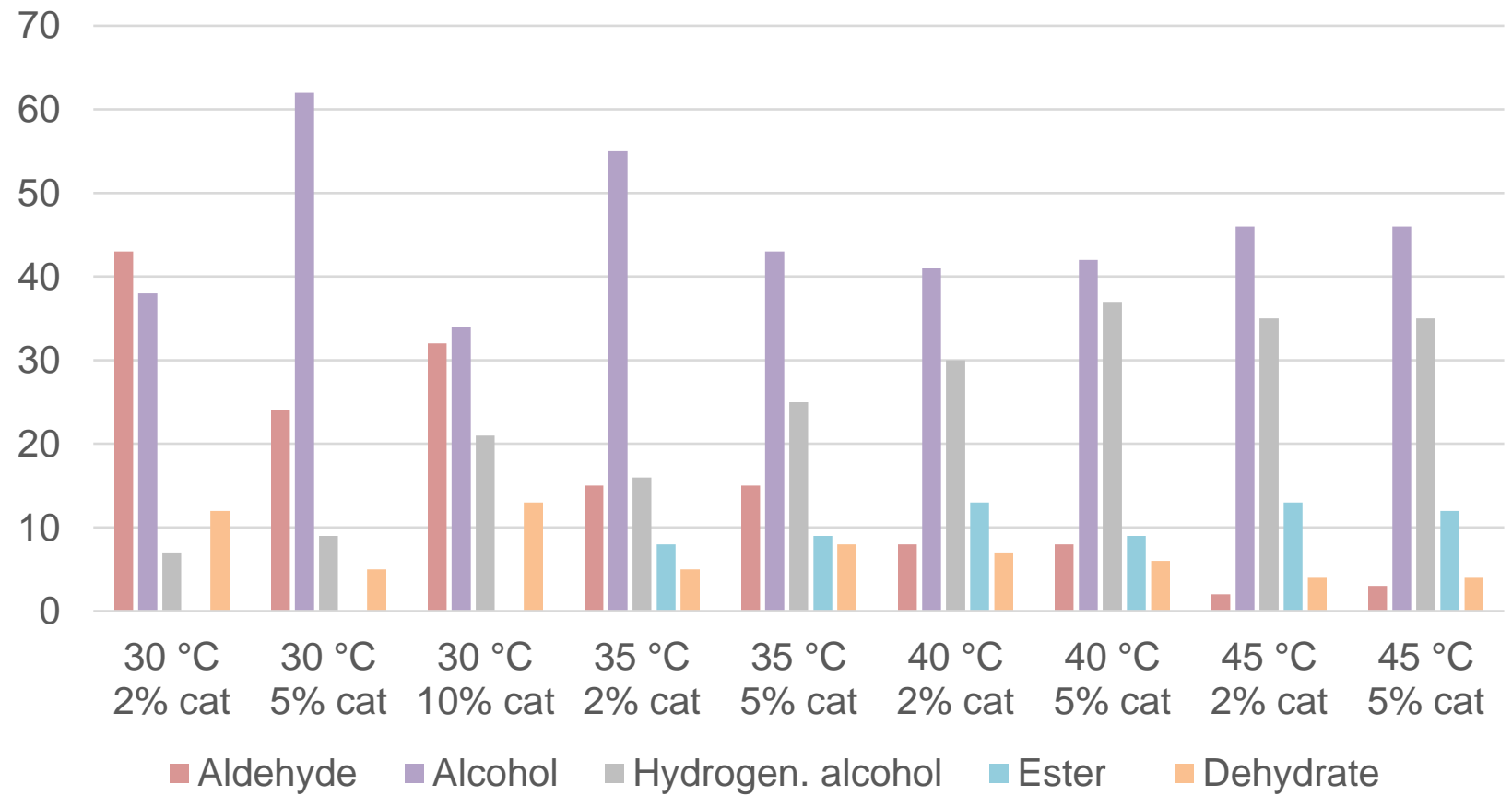


Figure S3. Enantioselective isomerization of (E)-3,7-dimethylocta-2,6-dien-1-ol influence of concentration, catalyst loading, and temperature.

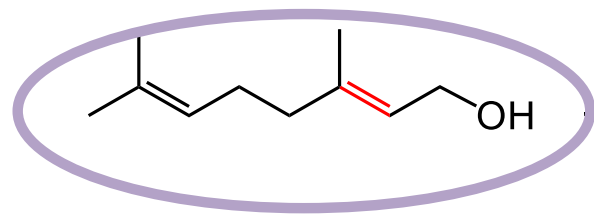

(S)-Ru-3 (x mol\%) $\mathrm{K}_{2} \mathrm{CO}_{3}(10 \mathrm{~mol} \%)$

$\mathrm{EtOH}(\mathrm{x} \mathrm{mL}), \mathrm{T}, 18 \mathrm{~h}$
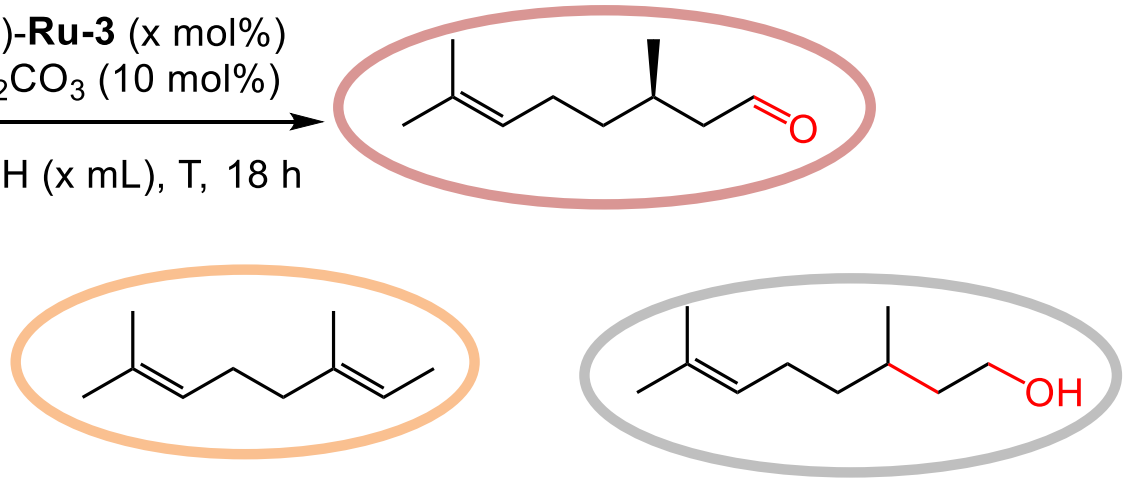

Yield (\%)

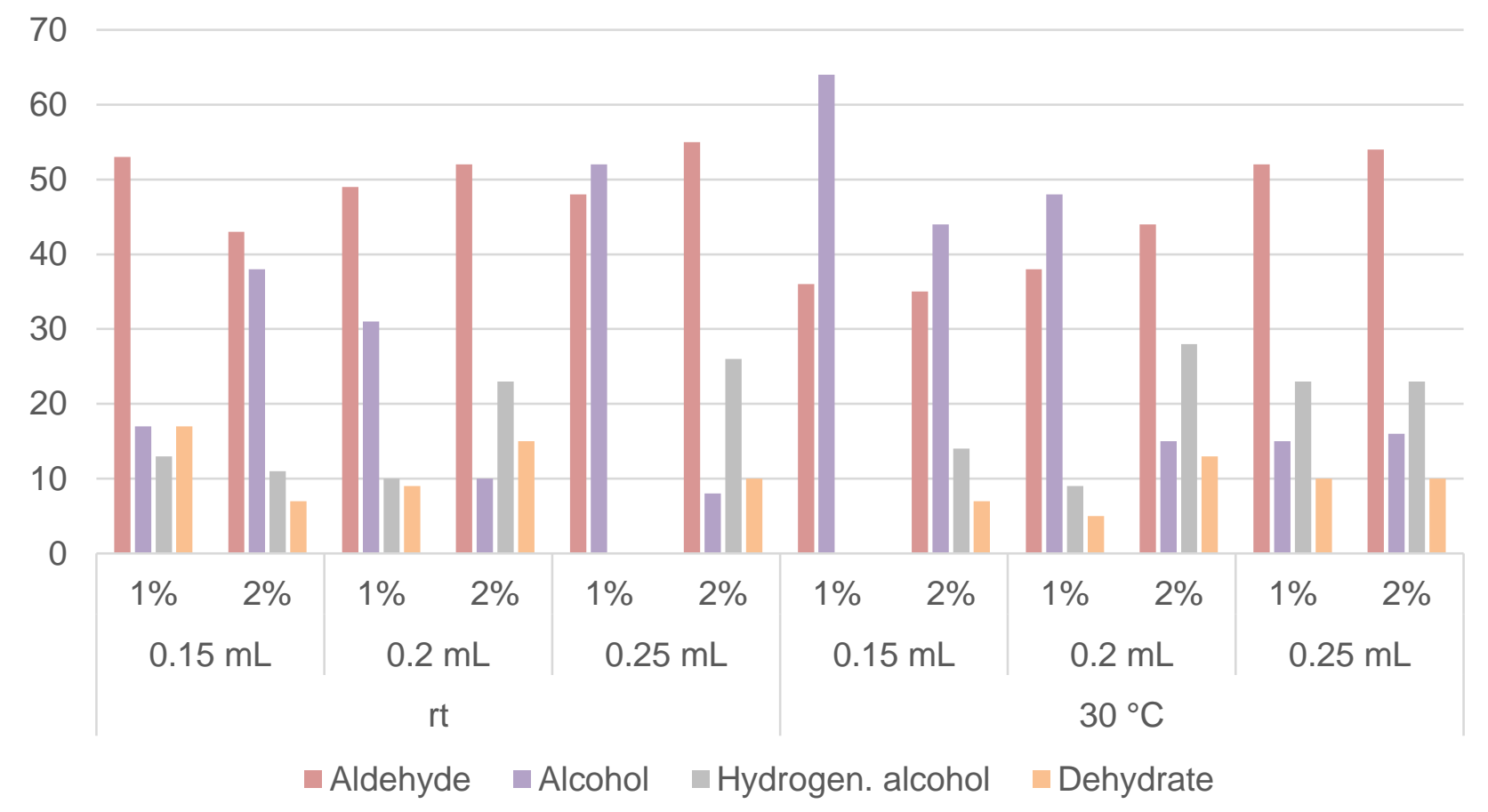


Figure S4. Enantioselective isomerization of (E)-3,7-dimethylocta-2,6-dien-1-ol influence of concentration.
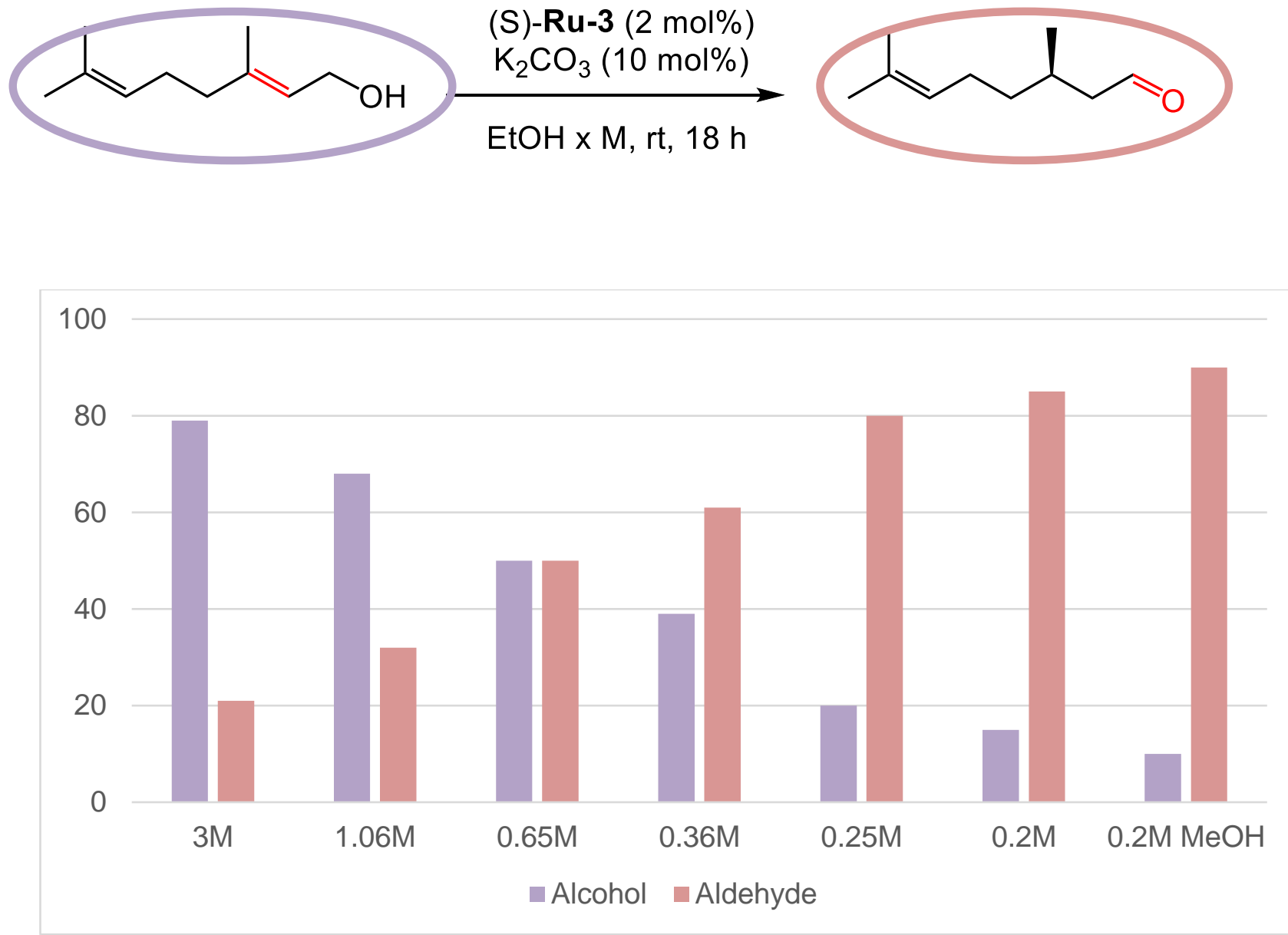
Table S5. Arylation of 3,7-dimethyloct-6-enal - influence of conditions and additives.

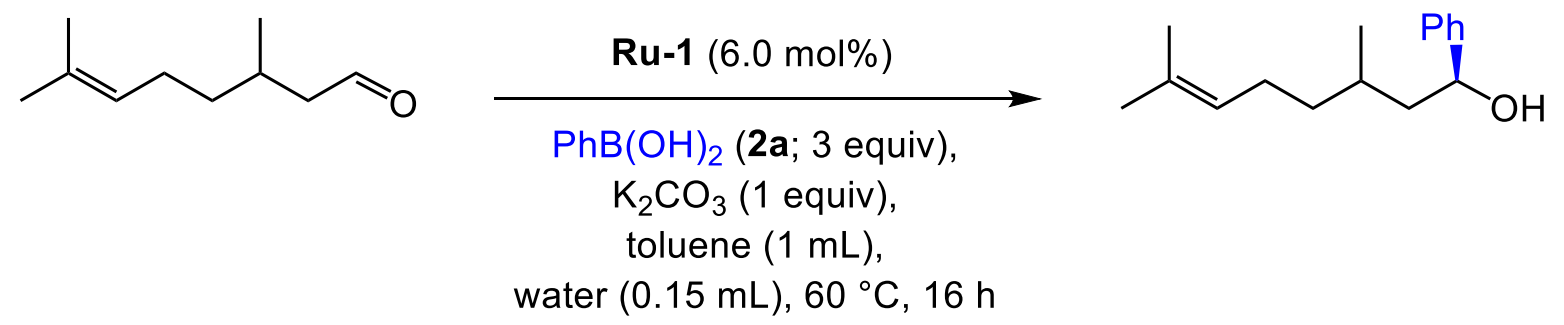

In a nitrogen-filled glovebox, a stock solution of Ru-1 was prepared by allowing to stir a mixture of $\left[\mathrm{Ru}(\mathrm{p} \text {-cymene }) \mathrm{Cl}_{2}\right]_{2}\left(4.6 \mathrm{mg}, 0.030\right.$ equiv, $\left.7.5 \times 10^{-3} \mathrm{mmol}\right)$ and Me-BIPAM (13 mg, 0.066 equiv, $\left.1.65 \times 10^{-2} \mathrm{mmol}\right)$ in toluene $(2 \mathrm{~mL})$ for $1 \mathrm{~h}$ at rt. Then, a $4 \mathrm{~mL}$ screwcap scintillation vial equipped with an octagonal stir bar $(2 \mathrm{~mm} \times 5 \mathrm{~mm})$ was charged with 3,7-dimethyloct-6-enal ( $27 \mu \mathrm{L}, 0.25 \mathrm{mmol}, 1.0$ equiv), the solution of $\mathbf{R u}-\mathbf{1}$, phenyl boronic acid (91 mg, $0.75 \mathrm{mmol}, 3.0$ equiv), $\mathrm{K}_{2} \mathrm{CO}_{3}$ ( $35 \mathrm{mg}, 1.0$ equiv), and degassed $\mathrm{H}_{2} \mathrm{O}$ (150 $\mu \mathrm{L})$. The vial was sealed with a Teflon-lined screw cap, removed from the glovebox, placed in a preheated aluminum block at $60{ }^{\circ} \mathrm{C}$ and allowed to stir at $800 \mathrm{rpm}$ for $16 \mathrm{~h}$. Next, the vial was removed from the heating block, let to cool to room temperature. The reaction mixture was then analyzed with the aid of GC-MS equipment. Yields were measured by GC-MS analysis with 1,3,5-trimethoxybenezene as an internal standard.

\begin{tabular}{cc}
\hline Changes from the above procedure & Yield (\%) \\
\hline None & Quant. \\
$30{ }^{\circ} \mathrm{C}$ & Quant. \\
$90{ }^{\circ} \mathrm{C}$ & $94 \%$ \\
$1 \mathrm{~mL}$ toluene & Quant. \\
$3 \mathrm{~mL}$ toluene & $93 \%$ \\
$0.1 \mathrm{~mL}$ water & Quant. \\
$0.3 \mathrm{~mL}$ water & Quant. \\
2 equiv $\mathrm{K}_{2} \mathrm{CO}_{3}$ & Quant. \\
4 equiv $\mathrm{K}_{2} \mathrm{CO}_{3}$ & Quant.
\end{tabular}


4 equiv $\mathrm{PhB}(\mathrm{OH})_{2}$

2 equiv $\mathrm{PhB}(\mathrm{OH})_{2}$

$1 \% \mathrm{Ru}-3$

2 x Ru-1

+ 6 mol\% Me-BIPAM

$1 / 2$ x Ru-1

$6 \mathrm{~h}$

$+0.10 \mathrm{~mL} \mathrm{EtOH}$
Quant.

Quant.

Quant.

Quant.

Quant.

Quant.

Quant.

$84 \%$ 
Figure S5. Arylation of 3,7-dimethyloct-6-enal - influence of co-solvent and water.<smiles>CC(C)=CCCC(C)CC=O</smiles>
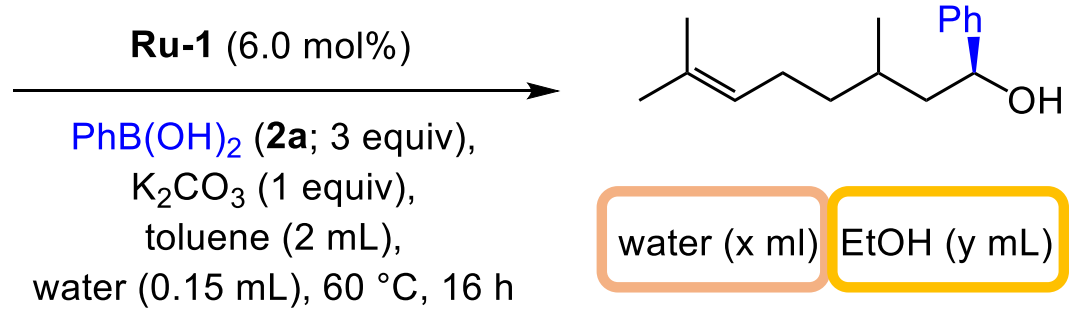

$$
\text { water (x ml) EtOH (y mL) }
$$

$\mathrm{H}_{2} \mathrm{O}$ and $\mathrm{EtOH}(\mu \mathrm{L})$

Yield (\%)

1.2

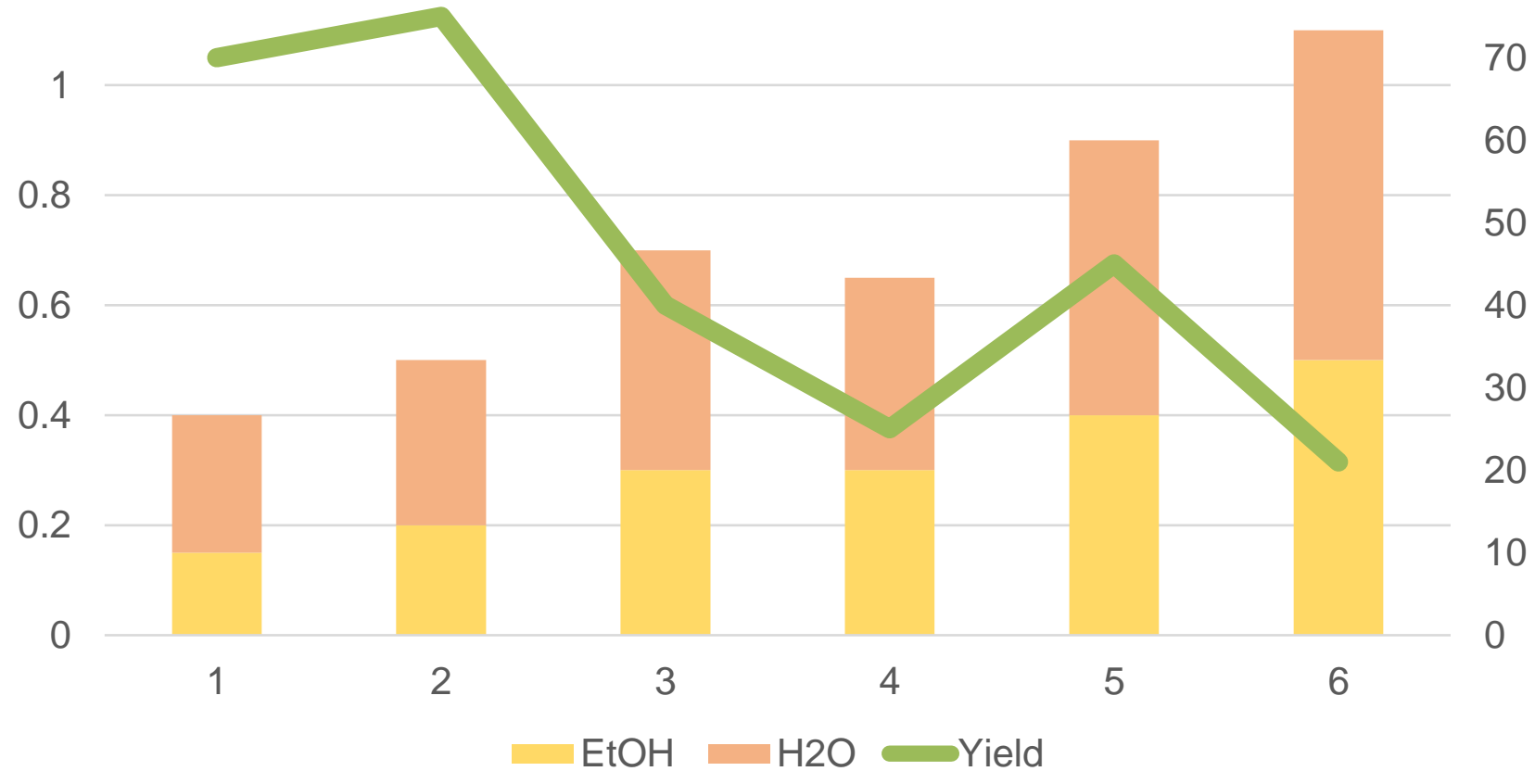




\section{B. General Procedures}

\section{General procedure 4: enantioselective isomerization and arylation of prochiral allylic alcohols}

In a nitrogen-filled glovebox, an oven-dried $4 \mathrm{~mL}$ screw-cap scintillation vial equipped with an octagonal stir bar ( $2 \mathrm{~mm} \times 5 \mathrm{~mm})$ was charged with an allylic alcohol $(0.25 \mathrm{mmol}$, 1 equiv), $\mathrm{K}_{2} \mathrm{CO}_{3}$ (3.5 mg, 0.10 equiv), $\mathbf{R u}-3$ ( $2.7 \mathrm{mg}, 0.010$ equiv) and degassed ethanol $(1.25 \mathrm{~mL})$. Next, the vial was sealed with a Teflon-lined screw and the solution was allowed to stir at room temperature $\left(25-28{ }^{\circ} \mathrm{C}\right)$ for $1 \mathrm{~h}$. Then, the volatiles were removed under reduced pressure at room temperature (with the aid of a vacuum line installed inside of the glovebox).* As soon as the volatiles were removed, dry toluene $(1 \mathrm{~mL})$ was added to the residue. (In the meantime, a stock solution of Ru-1 was prepared by allowing to stir a mixture of $\left[\mathrm{Ru}(\mathrm{p} \text {-cymene }) \mathrm{Cl}_{2}\right]_{2}\left(4.6 \mathrm{mg}, 0.030\right.$ equiv, $\left.7.5 \times 10^{-3} \mathrm{mmol}\right)$ and Me-BIPAM (13 mg, 0.066 equiv, $\left.1.65 \times 10^{-2} \mathrm{mmol}\right)$ in toluene $(1 \mathrm{~mL})$ for $1 \mathrm{~h}$ at $\mathrm{rt}$ ). Then, the solution of Ru-1, $\mathrm{K}_{2} \mathrm{CO}_{3}$ (35 mg, 1 equiv), arylboronic acid (3.0 equiv, $0.75 \mathrm{mmol}$ ) and degassed $\mathrm{H}_{2} \mathrm{O}(150 \mu \mathrm{L})$ were added to the reaction mixture. The vial was resealed with a Teflonlined screw cap, removed from the glovebox, placed in a preheated aluminum block at 60 ${ }^{\circ} \mathrm{C}$, and allowed to stir at $800 \mathrm{rpm}$ for $18 \mathrm{~h}$. Next, the vial was removed from the heating block, let to cool to room temperature, and the volatiles were removed under reduced pressure. The residue was subjected to flash column chromatography on silica gel (12 g), conducted with the aid of a Combiflash instrument, using a mixture of petroleum ether and ethyl acetate (usually with gradient of 100:0 - 80:20) as the eluent. Fractions containing the pure product (judged by the TLC and/or GC analyses) were combined, and the solvent was evaporated, yielding the target product.

* EtOH needs to be removed carefully because even a small amount ( 0.1-0.2 mL) can affect the subsequent step, as observed in control experiments (Table S5 and Figure S5). It is also important to evaporate the solvent at room temperature - we observed formation of aldol condensation products when the evaporation was performed at elevated temperatures. 


\section{Full Characterization of Reaction Products}

\section{(1S,3R)-3,7-dimethyl-1-phenyloct-6-en-1-ol (9aa)}

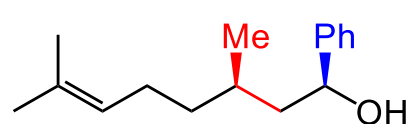

The compound 9aa was prepared according to General procedure 4 with (S,S)-Ru-1 and (S)-Ru-3 by reaction of (E)3,7-dimethylocta-2,6-dien-1-ol ( $27 \mu \mathrm{L}, 0.25 \mathrm{mmol})$ with phenylboronic acid $(91 \mathrm{mg}, 0.75$ mmol) and was isolated by column chromatography (silica gel, petroleum ether to petroleum ether/ethyl acetate 90:10) to give a transparent oil in $62 \%$ yield $(36 \mathrm{mg})$.

${ }^{1} \mathbf{H}$ NMR $\left(500 \mathrm{MHz}, \mathrm{CDCl}_{3}\right) \delta 7.38-7.34(\mathrm{~m}, 4 \mathrm{H}), 7.30-7.24(\mathrm{~m}, 1 \mathrm{H}), 5.16$ - $5.04(\mathrm{~m}$, $1 \mathrm{H}), 4.78(\mathrm{dd}, J=9.3,4.4 \mathrm{~Hz}, 1 \mathrm{H}), 2.07-1.92(\mathrm{~m}, 2 \mathrm{H}), 1.87-1.77(\mathrm{~m}, 2 \mathrm{H}), 1.71-1.64$ (m, 3H), 1.60 (s, 3H), $1.48-1.34$ (m, 2H), $1.29-1.15$ (m, 2H), 0.97 (d, J = 6.6 Hz, 3H). ${ }^{13} \mathbf{C}\left\{{ }^{1} \mathbf{H}\right\}$ NMR $\left(126 \mathrm{MHz}, \mathrm{CDCl}_{3}\right) \delta$ 145.7, 131.4, 128.6, 127.6, 125.9, 124.9, 72.6, 47.0, $37.8,29.4,25.8,25.6,19.4,17.8$.

HRMS (ESI) m/z: [M-H] $]^{+}$Calcd for $\mathrm{C}_{16} \mathrm{H}_{23} \mathrm{O}$ 231.1743; Found 231.1742.

SFC with Chiralpak ID-3, $1 \%$ iPrOH / 99\% CO $\mathrm{CO}_{2}, 1.2 \mathrm{~mL} / \mathrm{min}, \mathrm{t}$ (major, (1S,3R)-9aa) $=$ $3.29 \mathrm{~min}, \mathrm{t}(\operatorname{minor},(1 \mathrm{R}, 3 \mathrm{~S})-\mathbf{9 a a})=3.93 \mathrm{~min}$

Specific rotation: $[\alpha]_{\mathrm{D}}^{20}-6.5^{\circ}\left(\mathrm{c} 0.44, \mathrm{CHCl}_{3}\right)$ for an enantiomerically enriched sample of 99 : 1 er. The absolute configuration of $\mathrm{C} 3$ was assigned according to the previously reported selectivity of Ru-3 in isomerization of geraniol; ${ }^{4}$ the absolute configuration of $\mathrm{C} 1$ was assigned by analogy to the selectivity of the reaction observed with linear aldehydes (see above). The absolute configuration was not further verified. It is worth noting that the configuration of $\mathrm{C} 3$ has no observable effect on the selectivity of the reaction at $\mathrm{C} 1$ center, as implied from the experiments to prepare 9aa and 9aa'.

\section{(1R,3R)-3,7-dimethyl-1-phenyloct-6-en-1-ol (9aa')}

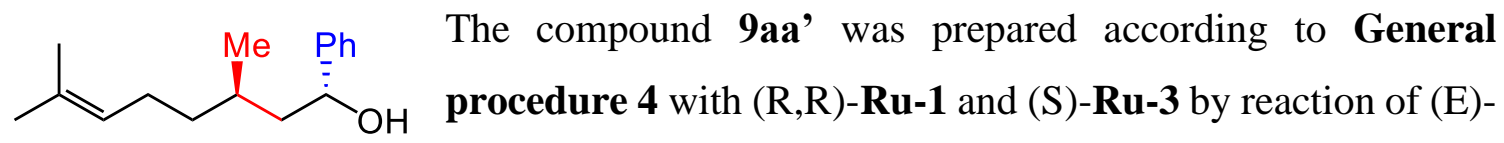

3,7-dimethylocta-2,6-dien-1-ol (27 $\mu \mathrm{L}, 0.25 \mathrm{mmol})$ with phenylboronic acid (91 mg, 0.75 mmol) and was isolated by column chromatography (silica gel, petroleum ether to petroleum ether/ethyl acetate 90:10) to give a transparent oil in 61\% yield (36 mg).

${ }^{1} \mathbf{H}$ NMR $\left(500 \mathrm{MHz}, \mathrm{CDCl}_{3}\right) \delta 7.35(\mathrm{~d}, \mathrm{~J}=4.0 \mathrm{~Hz}, 4 \mathrm{H}), 7.31-7.25(\mathrm{~m}, 1 \mathrm{H}), 5.11-5.00$ (m, 1H), $4.77(\mathrm{t}, \mathrm{J}=7.0 \mathrm{~Hz}, 1 \mathrm{H}), 2.02-1.88(\mathrm{~m}, 2 \mathrm{H}), 1.81(\mathrm{~s}, 1 \mathrm{H}) 1.71-1.64(\mathrm{~m}, 4 \mathrm{H})$, 
$1.62-1.54(\mathrm{~m}, 3 \mathrm{H}), 1.51-1.38(\mathrm{~m}, 2 \mathrm{H}), 1.32-1.23(\mathrm{~m}, 1 \mathrm{H}), 1.20-1.12(\mathrm{~m}, 1 \mathrm{H}), 0.95$ $(\mathrm{d}, \mathrm{J}=6.6 \mathrm{~Hz}, 3 \mathrm{H})$.

${ }^{13} \mathbf{C}\left\{{ }^{1} \mathbf{H}\right\}$ NMR $\left(126 \mathrm{MHz}, \mathrm{CDCl}_{3}\right) \delta 145.1,131.4,128.6,127.7,126.1,124.8,73.0,46.5$, $36.9,29.5,25.8,25.4,20.2,17.8$.

HRMS (ESI) m/z: [M-H] $]^{+}$Calcd for $\mathrm{C}_{16} \mathrm{H}_{23} \mathrm{O}$ 231.1743; Found 231.1743.

SFC with Chiralpak IB N-3, 2\% MeOH / 98\% CO $2,1.2 \mathrm{~mL} / \mathrm{min}$, t(major, (1R,3R)-9aa') $=2.66 \mathrm{~min}, \mathrm{t}\left(\operatorname{minor},(1 \mathrm{~S}, 3 \mathrm{~S})-\mathbf{9} \mathrm{aa}^{\prime}\right)=2.84 \mathrm{~min}$

Specific rotation: $[\alpha]_{\mathrm{D}}^{20}+19.5^{\circ}$ (c $0.60, \mathrm{CHCl}_{3}$ ) for an enantiomerically enriched sample of $99: 1$ er. The absolute configuration was assigned by an analogous approach to that for 9aa. The absolute configuration was not further verified.

\section{(1S,3S)-3,7-dimethyl-1-phenyloct-6-en-1-ol (9ba')}

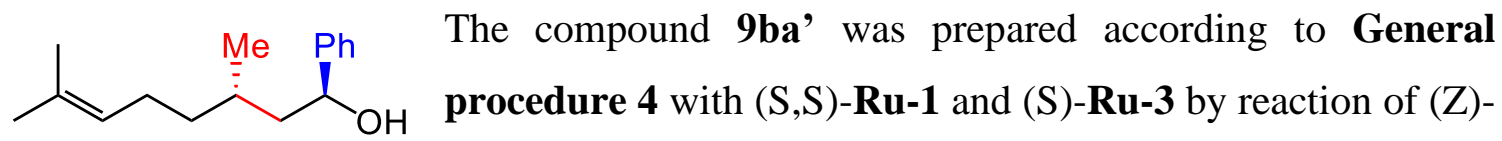
3,7-dimethylocta-2,6-dien-1- ol ( $27 \mu \mathrm{L}, 0.25 \mathrm{mmol})$ with phenylboronic acid $(91 \mathrm{mg}, 0.75$ mmol) and was isolated by column chromatography (silica gel, petroleum ether to petroleum ether/ethyl acetate 90:10) to give a transparent oil in 60\% yield (35 mg).

${ }^{1} \mathbf{H}$ NMR $\left(500 \mathrm{MHz}, \mathrm{CDCl}_{3}\right) \delta 7.35(\mathrm{~d}, \mathrm{~J}=4.0 \mathrm{~Hz}, 4 \mathrm{H}), 7.31-7.25(\mathrm{~m}, 1 \mathrm{H}), 5.11-5.00$ (m, 1H), $4.77(\mathrm{t}, \mathrm{J}=7.0 \mathrm{~Hz}, 1 \mathrm{H}), 2.02-1.88(\mathrm{~m}, 2 \mathrm{H}), 1.81(\mathrm{~s}, 1 \mathrm{H}) 1.71-1.64(\mathrm{~m}, 4 \mathrm{H})$, $1.62-1.54(\mathrm{~m}, 3 \mathrm{H}), 1.51-1.38(\mathrm{~m}, 2 \mathrm{H}), 1.32-1.23(\mathrm{~m}, 1 \mathrm{H}), 1.20-1.12(\mathrm{~m}, 1 \mathrm{H}), 0.95$ $(\mathrm{d}, \mathrm{J}=6.6 \mathrm{~Hz}, 3 \mathrm{H})$.

${ }^{13} \mathbf{C}\left\{{ }^{1} \mathbf{H}\right\}$ NMR $\left(126 \mathrm{MHz}, \mathrm{CDCl}_{3}\right) \delta 145.1,131.4,128.6,127.7,126.1,124.8,73.0,46.5$, $36.9,29.5,25.8,25.4,20.2,17.8$.

HRMS (ESI) m/z: [M-H] ${ }^{+}$Calcd for $\mathrm{C}_{16} \mathrm{H}_{23} \mathrm{O}$ 231.1743; Found 231.1745.

SFC with Chiralpak IB N-3, 2\% MeOH / 98\% CO $2,1.2 \mathrm{~mL} / \mathrm{min}$, t(minor, (1R,3R)-9ba') $=2.66 \mathrm{~min}, \mathrm{t}\left(\right.$ major, $\left.(1 \mathrm{~S}, 3 \mathrm{~S})-9 \mathbf{b a}^{\prime}\right)=2.84 \mathrm{~min}$.

Specific rotation: $[\alpha]_{\mathrm{D}}^{20}-19.8^{\circ}\left(\mathrm{c} 0.62, \mathrm{CHCl}_{3}\right)$ for an enantiomerically enriched sample of $99: 1$ er. The absolute configuration was assigned by an analogous approach to that for 9aa. The absolute configuration was not further verified.

(1S,3R,7R,11R)-3,7,11,15-tetramethyl-1-phenylhexadecan-1-ol (9ca) 


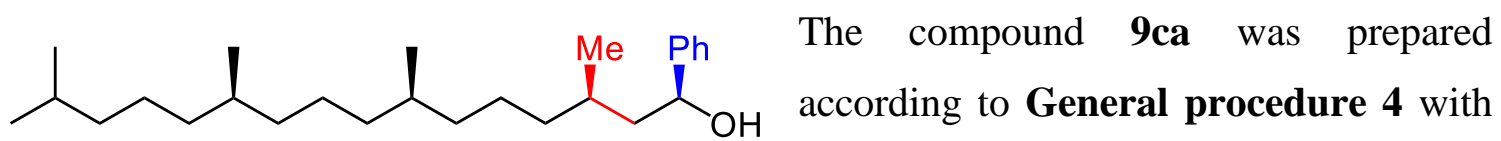

(S,S)-Ru-1 and (S)-Ru-3 by reaction of (2E,7R,11R)-3,7,11,15-tetramethylhexadec-2-en1 -ol ( $86 \mu \mathrm{L}, 0.25 \mathrm{mmol})$ with phenylboronic acid $(91 \mathrm{mg}, 0.75 \mathrm{mmol})$ and was isolated by column chromatography (silica gel, petroleum ether to petroleum ether/ethyl acetate 90:10) to give a pale-yellow oil in $70 \%$ yield $(65 \mathrm{mg})$. The SFC analysis revealed that besides $(1 \mathrm{~S}, 3 \mathrm{R}, 7 \mathrm{R}, 11 \mathrm{R})-9 \mathrm{ca}$ product, the isolated material contained $1.5 \%$ of the other 1,3 -syn diastereomers of the product, i.e., (1R,3S,7R,11R)-9ca. Independent synthesis of $(1 \mathrm{R}, 3 \mathrm{~S}, 7 \mathrm{R}, 11 \mathrm{R})-9 \mathrm{ca}$ as major diastereomer showed that both 1,3-syn diastereomers are indistinguishable by ${ }^{1} \mathrm{H}$ and ${ }^{13} \mathrm{C}$ NMR spectroscopy.

${ }^{1} \mathbf{H}$ NMR $\left(500 \mathrm{MHz}, \mathrm{CDCl}_{3}\right) \delta 7.38-7.33(\mathrm{~m}, 4 \mathrm{H}), 7.32-7.24(\mathrm{~m}, 1 \mathrm{H}), 4.78(\mathrm{dd}, J=9.4$, $4.3 \mathrm{~Hz}, 1 \mathrm{H}), 1.82(\mathrm{td}, J=9.3,4.7 \mathrm{~Hz}, 1 \mathrm{H}), 1.70-1.62(\mathrm{~m}, 1 \mathrm{H}), 1.53(\mathrm{dp}, J=13.3,6.6 \mathrm{~Hz}$, $1 \mathrm{H}), 1.46-1.34(\mathrm{~m}, 3 \mathrm{H}), 1.35-1.21(\mathrm{~m}, 10 \mathrm{H}), 1.22-1.10(\mathrm{~m}, 4 \mathrm{H}), 1.11-1.01(\mathrm{~m}, 4 \mathrm{H})$, $0.96(\mathrm{~d}, J=6.6 \mathrm{~Hz}, 3 \mathrm{H}), 0.90-0.81(\mathrm{~m}, 12 \mathrm{H})$.

${ }^{13} \mathbf{C}\left\{{ }^{1} \mathbf{H}\right\}$ NMR $\left(126 \mathrm{MHz}, \mathrm{CDCl}_{3}\right) \delta$ 145.7, 128.6, 127.6, 125.9, 72.6, 47.1, 39.6, 38.1, 37.7, 37.5, 37.5, 33.1, 33.0, 29.7, 28.2, 25.0, 24.7, 24.5, 22.9, 22.8, 19.93, 19.88, 19.5.

HRMS (ESI) m/z: [M-H] ${ }^{+}$Calcd for $\mathrm{C}_{26} \mathrm{H}_{45} \mathrm{O}$ 373.3465; Found 373.3468.

SFC with Chiralpak IG-3, 2\% MeOH / 98\% CO $2,1.2 \mathrm{~mL} / \mathrm{min}$, t(major, (1S,3R,7R,11R)9ca $)=4.56 \mathrm{~min}, \mathrm{t}(\operatorname{minor},(1 \mathrm{R}, 3 \mathrm{~S}, 7 \mathrm{R}, 11 \mathrm{R})-9 \mathrm{ca})=5.88 \mathrm{~min}$

Specific rotation: $[\alpha]_{\mathrm{D}}{ }^{20}-21.8^{\circ}\left(\mathrm{c} 0.58, \mathrm{CHCl}_{3}\right)$ for a sample containing a $98.5: 1.5$ mixture of 1,3-syn diastereomers ((1S,3R,7R,11R)-9ca :(1R,3S,7R,11R)-9ca)).

Specific rotation: $[\alpha]_{\mathrm{D}}{ }^{20}+5.9^{\circ}\left(\mathrm{c} 0.51, \mathrm{CHCl}_{3}\right)$ for a sample containing a $4: 96$ mixture of 1,3-syn diastereomers ((1S,3R,7R,11R)-9ca : (1R,3S,7R,11R)-9ca)).

The absolute configuration was assigned by analogy to $9 \mathbf{a a}$. The absolute configuration was not further verified. 
(1S,3R,7R,11R)-1-(4-methoxyphenyl)-3,7,11,15-tetramethylhexadecan-1-ol (9cb)

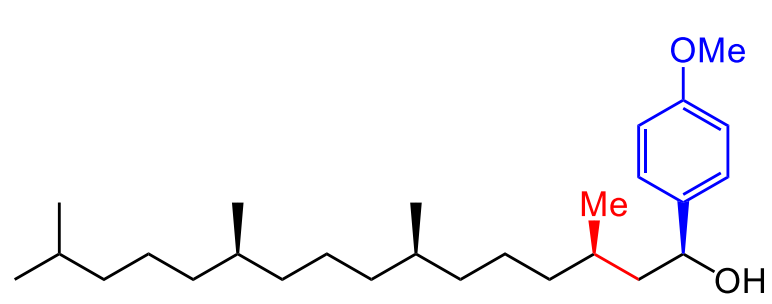

The compound 9cb was prepared according to General procedure 4 with (S,S)-Ru-1 and (S)-Ru-3 by reaction of (2E,7R,11R)-3,7,11,15-

tetramethylhexadec-2-en-1-ol $\quad(86 \mu \mathrm{L}$, $0.25 \mathrm{mmol}$ )with (4-methoxyphenyl)boronic acid $(107 \mathrm{mg}, 0.75 \mathrm{mmol})$ and was isolated by column chromatography (silica gel, petroleum ether to petroleum ether/ethyl acetate 85:15) to give a pale yellow oil in $47 \%$ yield $(47 \mathrm{mg})$. The SFC analysis revealed that besides $(1 \mathrm{~S}, 3 \mathrm{R}, 7 \mathrm{R}, 11 \mathrm{R})-9 \mathrm{cb}$ product, the isolated material contained $1 \%$ of the other 1,3-syn diastereomers of the product, i.e., (1R,3S,7R,11R)-9cb. Independent synthesis of $(1 \mathrm{R}, 3 \mathrm{~S}, 7 \mathrm{R}, 11 \mathrm{R})-\mathbf{9 c b}$ as major diastereomer showed that both 1,3-syn diastereomers are indistinguishable by ${ }^{1} \mathrm{H}$ and ${ }^{13} \mathrm{C}$ NMR spectroscopy.

${ }^{1} \mathbf{H}$ NMR $\left(500 \mathrm{MHz}, \mathrm{CDCl}_{3}\right) \delta 7.30-7.26(\mathrm{~m}, 2 \mathrm{H}), 6.91-6.85(\mathrm{~m}, 2 \mathrm{H}), 4.73(\mathrm{dd}, J=9.2$, $4.6 \mathrm{~Hz}, 1 \mathrm{H}), 3.81$ (s, 3H), $1.86-1.77$ (m, 1H), $1.68-1.59$ (m, 1H), 1.52 (dp, $J=13.3,6.7$ $\mathrm{Hz}, 1 \mathrm{H}), 1.40-1.35(\mathrm{~m}, 3 \mathrm{H}), 1.31-1.20(\mathrm{~m}, 10 \mathrm{H}), 1.18-1.11(\mathrm{~m}, 4 \mathrm{H}), 1.09-1.02(\mathrm{~m}$, $4 \mathrm{H}), 0.93(\mathrm{~d}, J=6.6 \mathrm{~Hz}, 3 \mathrm{H}), 0.87(\mathrm{dd}, J=6.7,0.8 \mathrm{~Hz}, 6 \mathrm{H}), 0.84(\mathrm{dd}, J=6.7,1.8 \mathrm{~Hz}, 6 \mathrm{H})$. ${ }^{13} \mathbf{C}\left\{{ }^{1} \mathbf{H}\right\}$ NMR $\left(126 \mathrm{MHz}, \mathrm{CDCl}_{3}\right) \delta$ 159.1, 137.8, 127.2, 114.0, 72.1, 55.4, 46.8, 39.5, 38.0, $37.6,37.5,37.4,33.0,32.9,29.7,28.1,25.0,24.6,24.4,22.9,22.8,19.92,19.89,19.5$.

HRMS (ESI) m/z: [M-H] ${ }^{+}$Calcd for $\mathrm{C}_{27} \mathrm{H}_{47} \mathrm{O}_{2}$ 403.3571; Found 403.3575.

SFC with Chiralpak ID-3, 3\% MeOH / 97\% CO $2,1.2 \mathrm{~mL} / \mathrm{min}$, t(major, (1S,3R,7R,11R)$9 \mathbf{c b})=2.66 \mathrm{~min}, \mathrm{t}(\mathrm{minor},(1 \mathrm{R}, 3 \mathrm{~S}, 7 \mathrm{R}, 11 \mathrm{R})-9 \mathrm{cb})=3.28 \mathrm{~min}$

Specific rotation: $[\alpha]_{\mathrm{D}}{ }^{20}-22.4^{\circ}$ (c $0.64, \mathrm{CHCl}_{3}$ ) for a sample containing a 99 : 1 mixture of 1,3-syn diastereomers ((1S,3R,7R,11R)-9cb :(1R,3S,7R,11R)-9cb)).

Specific rotation: $[\alpha]_{\mathrm{D}}^{20}+20.8^{\circ}\left(\mathrm{c} 0.51, \mathrm{CHCl}_{3}\right)$ for a sample containing a $1: 99$ mixture of 1,3-syn diastereomers ((1S,3R,7R,11R)-9cb :(1R,3S,7R,11R)-9cb)).

The absolute configuration was assigned by analogy to $9 \mathbf{a a}$. The absolute configuration was not further verified. 
(1S,3R,7R,11R)-3,7,11,15-tetramethyl-1-(p-tolyl)hexadecan-1-ol (9cc)

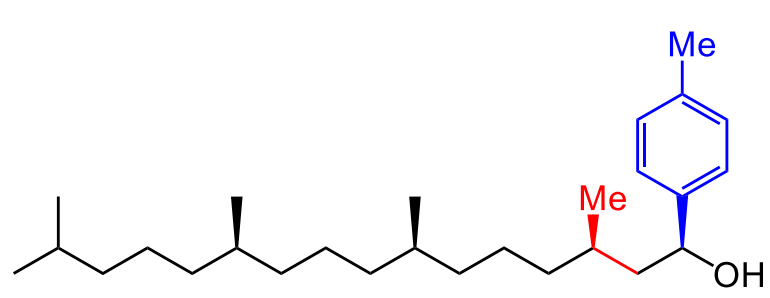

The compound 9cc was prepared according to General procedure 4 with (S,S)-Ru-1 and (S)- Ru-3 by reaction of (2E,7R,11R)-3,7,11,15-

tetramethylhexadec-2-en-1-ol $\quad(86 \mu \mathrm{L}$, $0.25 \mathrm{mmol}$ ) with $p$-tolylboronic acid (102 $\mathrm{mg}, 0.75 \mathrm{mmol})$ and was isolated by column chromatography (silica gel, petroleum ether to petroleum ether/ethyl acetate 90:10) to give a transparent oil in 59\% yield $(57 \mathrm{mg})$. The SFC analysis revealed that besides $(1 \mathrm{~S}, 3 \mathrm{R}, 7 \mathrm{R}, 11 \mathrm{R})-9 \mathrm{cc}$ product, the isolated material contained $5 \%$ of the other 1,3-syn diastereomers of the product, i.e., (1R,3S,7R,11R)-9cc. Independent synthesis of $(1 \mathrm{R}, 3 \mathrm{~S}, 7 \mathrm{R}, 11 \mathrm{R})-9 \mathrm{cc}$ as major diastereomer showed that both 1,3-syn diastereomers are indistinguishable by ${ }^{1} \mathrm{H}$ and ${ }^{13} \mathrm{C}$ NMR spectroscopy.

${ }^{1} \mathbf{H}$ NMR $\left(500 \mathrm{MHz}, \mathrm{CDCl}_{3}\right) \delta 7.30-7.23(\mathrm{~m}, 2 \mathrm{H}), 7.18(\mathrm{~d}, J=7.9 \mathrm{~Hz}, 2 \mathrm{H}), 4.76(\mathrm{dd}, J=$ 9.3, 4.4 Hz, 1H), $2.37(\mathrm{~s}, 3 \mathrm{H}), 1.87-1.80(\mathrm{~m}, 1 \mathrm{H}), 1.77(\mathrm{~s}, 1 \mathrm{H}), 1.71-1.62(\mathrm{~m}, 1 \mathrm{H}), 1.55$ $(\mathrm{dp}, J=13.2,6.6 \mathrm{~Hz}, 1 \mathrm{H}), 1.46-1.37(\mathrm{~m}, 3 \mathrm{H}), 1.34-1.24(\mathrm{~m}, 10 \mathrm{H}), 1.23-1.14(\mathrm{~m}, 4 \mathrm{H})$, $1.13-1.04(\mathrm{~m}, 4 \mathrm{H}), 0.97(\mathrm{~d}, J=6.6 \mathrm{~Hz}, 3 \mathrm{H}), 0.92-0.84(\mathrm{~m}, 12 \mathrm{H})$.

${ }^{13} \mathbf{C}\left\{{ }^{1} \mathbf{H}\right\}$ NMR $\left(126 \mathrm{MHz}, \mathrm{CDCl}_{3}\right) \delta 142.7,137.2,129.3,125.9,72.4,47.0,39.5,38.0$, $37.64,37.63,37.5,33.0,32.9,29.6,28.1,25.0,24.6,24.4,22.9,22.8,21.3,19.94,19.91$, 19.4 .

HRMS (ESI) m/z: [M-H] $]^{+}$Calcd for $\mathrm{C}_{27} \mathrm{H}_{47} \mathrm{O}$ 387.3621; Found 387.3620.

SFC with Chiralpak IC-3, 2\% MeOH / 98\% CO $2,1.2 \mathrm{~mL} / \mathrm{min}$, t(major, (1S,3R,7R,11R)$\mathbf{9 c c})=2.01 \mathrm{~min}, \mathrm{t}($ minor, $(1 \mathrm{R}, 3 \mathrm{~S}, 7 \mathrm{R}, 11 \mathrm{R})-\mathbf{9 c c})=3.01 \mathrm{~min}$

Specific rotation: $[\alpha]_{\mathrm{D}}{ }^{20}-16.9^{\circ}\left(\mathrm{c} 0.57, \mathrm{CHCl}_{3}\right)$ for a sample containing a $95: 5$ mixture of 1,3-syn diastereomers ((1S,3R,7R,11R)-9cc :(1R,3S,7R,11R)-9cc)).

Specific rotation: $[\alpha]_{\mathrm{D}}{ }^{20}+18.4^{\circ}\left(\mathrm{c} 0.64, \mathrm{CHCl}_{3}\right)$ for a sample containing a $3: 97$ mixture of 1,3-syn diastereomers ((1S,3R,7R,11R)-9cc :(1R,3S,7R,11R)-9cc)).

The absolute configuration was assigned by analogy to $9 \mathbf{a a}$. The absolute configuration was not further verified. 
(1S,3R,7R,11R)-1-(4-isopropylphenyl)-3,7,11,15-tetramethylhexadecan-1-ol (9cd)

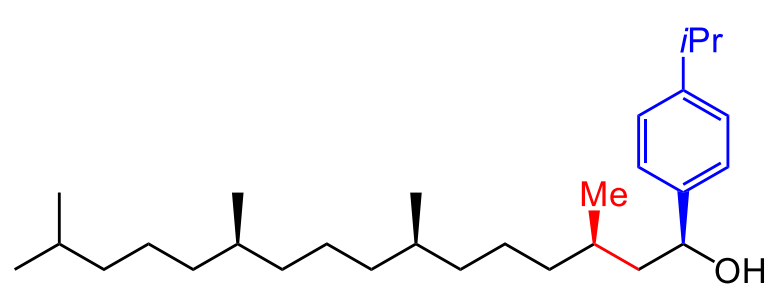

The compound 9cd was prepared according to General procedure 4 with (S,S)-Ru-1 and (S)- Ru-3 by reaction of (2E,7R,11R)-3,7,11,15-

tetramethylhexadec-2-en-1-ol $\quad(86 \mu \mathrm{L}$, $0.25 \mathrm{mmol}$ ) with (4-isopropylphenyl)boronic acid $(128 \mathrm{mg}, 0.75 \mathrm{mmol})$ and was isolated by column chromatography (silica gel, petroleum ether to petroleum ether/ethyl acetate 90:10) to give a yellow oil in 55\% yield (57 $\mathrm{mg})$. The SFC analysis revealed that besides $(1 \mathrm{~S}, 3 \mathrm{R}, 7 \mathrm{R}, 11 \mathrm{R})-9 \mathrm{~cd}$ product, the isolated material contained $0.5 \%$ of the other 1,3 -syn diastereomers of the product, i.e., $(1 \mathrm{R}, 3 \mathrm{~S}, 7 \mathrm{R}, 11 \mathrm{R})-\mathbf{9 c d}$. Independent synthesis of $(1 \mathrm{R}, 3 \mathrm{~S}, 7 \mathrm{R}, 11 \mathrm{R})-9 \mathrm{~cd}$ as major diastereomer showed that both 1,3-syn diastereomers are indistinguishable by ${ }^{1} \mathrm{H}$ and ${ }^{13} \mathrm{C}$ NMR spectroscopy.

${ }^{1} \mathbf{H}$ NMR $\left(500 \mathrm{MHz}, \mathrm{CDCl}_{3}\right) \delta 7.29(\mathrm{~d}, J=8.2 \mathrm{~Hz}, 2 \mathrm{H}), 7.21(\mathrm{~d}, J=8.2 \mathrm{~Hz}, 2 \mathrm{H}), 4.75(\mathrm{dd}$, $J=9.4,4.2 \mathrm{~Hz}, 1 \mathrm{H}), 2.91$ (p, $J=6.9 \mathrm{~Hz}, 1 \mathrm{H}), 1.87-1.79$ (m, 1H), 1.74 (s, 1H), $1.71-$ $1.64(\mathrm{~m}, 1 \mathrm{H}), 1.53(\mathrm{dp}, J=13.2,6.6 \mathrm{~Hz}, 1 \mathrm{H}), 1.45-1.35(\mathrm{~m}, 4 \mathrm{H}), 1.33-1.22(\mathrm{~m}, 14 \mathrm{H})$, $1.22-1.11(\mathrm{~m}, 4 \mathrm{H}), 1.11-1.02(\mathrm{~m}, 4 \mathrm{H}), 0.96(\mathrm{~d}, J=6.6 \mathrm{~Hz}, 3 \mathrm{H}), 0.92-0.81(\mathrm{~m}, 12 \mathrm{H})$.

${ }^{13} \mathbf{C}\left\{{ }^{1} \mathbf{H}\right\}$ NMR $\left(126 \mathrm{MHz}, \mathrm{CDCl}_{3}\right) \delta 148.3,143.1,126.6,125.9,72.3,46.9,39.5,38.1$, $37.64,37.61,37.5,34.0,33.0,32.9,29.6,28.1,25.0,24.6,24.4,24.2,22.9,22.8,19.92$, $19.87,19.4$.

HRMS (ESI) m/z: [M-H] $]^{+}$Calcd for $\mathrm{C}_{29} \mathrm{H}_{51} \mathrm{O}$ 415.3934; Found 415.3937.

SFC with Chiralpak IG-3, 3\% MeOH / 97\% CO, $1.2 \mathrm{~mL} / \mathrm{min}$, t(minor, (1R,3S,7R,11R)$\mathbf{9 c d})=5.62 \mathrm{~min}, \mathrm{t}($ major, $(1 \mathrm{~S}, 3 \mathrm{R}, 7 \mathrm{R}, 11 \mathrm{R})-9 \mathrm{~cd})=6.36 \mathrm{~min}$.

Specific rotation: $[\alpha]_{\mathrm{D}}{ }^{20}-20.7^{\circ}\left(\mathrm{c} 0.66, \mathrm{CHCl}_{3}\right)$ for a sample containing a $99.5: 0.5$ mixture of 1,3-syn diastereomers ((1S,3R,7R,11R)-9cd :(1R,3S,7R,11R)-9cd)).

Specific rotation: $[\alpha]_{\mathrm{D}}{ }^{20}+18.3^{\circ}\left(\mathrm{c} 0.71, \mathrm{CHCl}_{3}\right)$ for a sample containing a $0.5: 99.5$ mixture of 1,3-syn diastereomers ((1S,3R,7R,11R)-9cd :(1R,3S,7R,11R)-9cd)).

The absolute configuration was assigned by analogy to $9 \mathbf{a a}$. The absolute configuration was not further verified. 
(1S,3R,7R,11R)-3,7,11,15-tetramethyl-1-(4-(methylthio)phenyl)hexadecan-1-ol (9ce)

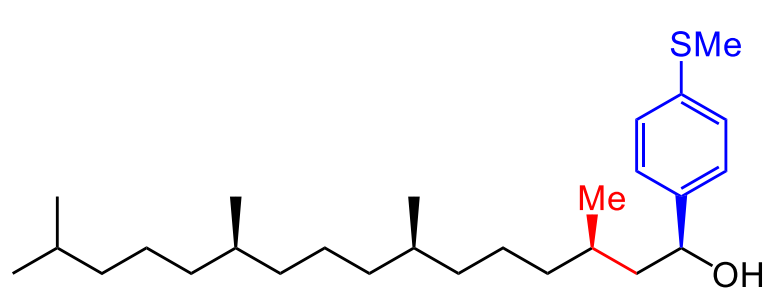

The compound 9ce was prepared according to General procedure 4 with (S,S)-Ru-1 and (S)- Ru-3 by reaction of (2E,7R,11R)-3,7,11,15-

tetramethylhexadec-2-en-1-ol $\quad(86 \mu \mathrm{L}$, $0.25 \mathrm{mmol}$ )with (4-(methylthio)phenyl)boronic acid ( $126 \mathrm{mg}, 0.75 \mathrm{mmol}$ ) and was isolated by column chromatography (silica gel, petroleum ether to petroleum ether/ethyl acetate $85: 15)$ to give a yellow oil in $43 \%$ yield $(45 \mathrm{mg})$. The SFC analysis revealed that besides $(1 \mathrm{~S}, 3 \mathrm{R}, 7 \mathrm{R}, 11 \mathrm{R})-9 \mathrm{ce}$ product, the isolated material contained $4 \%$ of the other 1,3 -syn diastereomers of the product, i.e., (1R,3S,7R,11R)-9ce. Independent synthesis of $(1 \mathrm{R}, 3 \mathrm{~S}, 7 \mathrm{R}, 11 \mathrm{R})-9 \mathrm{ce}$ as major diastereomer showed that both 1,3-syn diastereomers are indistinguishable by ${ }^{1} \mathrm{H}$ and ${ }^{13} \mathrm{C}$ NMR spectroscopy.

${ }^{1} \mathbf{H}$ NMR $\left(500 \mathrm{MHz}, \mathrm{CDCl}_{3}\right) \delta 7.37-7.18(\mathrm{~m}, 4 \mathrm{H}), 4.76(\mathrm{dd}, J=9.3,4.4 \mathrm{~Hz}, 1 \mathrm{H}), 2.50(\mathrm{~s}$, $3 \mathrm{H}), 1.81$ (ddd, $J=13.9,9.3,4.7 \mathrm{~Hz}, 1 \mathrm{H}), 1.72-1.60(\mathrm{~m}, 2 \mathrm{H}), 1.54(\mathrm{dq}, J=13.3,6.6 \mathrm{~Hz}$, $1 \mathrm{H}), 1.45-1.35(\mathrm{~m}, 3 \mathrm{H}), 1.33-1.22(\mathrm{~m}, 10 \mathrm{H}), 1.22-1.11(\mathrm{~m}, 4 \mathrm{H}), 1.12-1.02(\mathrm{~m}, 4 \mathrm{H})$, $0.96(\mathrm{~d}, J=6.6 \mathrm{~Hz}, 3 \mathrm{H}), 0.91-0.83(\mathrm{~m}, 12 \mathrm{H})$.

${ }^{13} \mathbf{C}\left\{{ }^{1} \mathbf{H}\right\}$ NMR $\left(126 \mathrm{MHz}, \mathrm{CDCl}_{3}\right) \delta 142.6,137.5,127.0,126.5,72.1,47.0,39.5,38.0$, $37.61,37.60,37.4,32.95,32.93,29.6,28.1,25.0,24.6,24.4,22.9,22.8,19.91,19.87,19.4$, 16.2 .

HRMS (ESI) m/z: [M-H] $]^{+}$Calcd for $\mathrm{C}_{27} \mathrm{H}_{47} \mathrm{OS}$ 419.3342; Found 419.3345 .

SFC with Chiralpak IC-3, 5\% MeOH / 95\% CO, $1.2 \mathrm{~mL} / \mathrm{min}$, t(minor, (1R,3S,7R,11R)9ce $)=2.94 \mathrm{~min}, \mathrm{t}($ major, $(1 \mathrm{~S}, 3 \mathrm{R}, 7 \mathrm{R}, 11 \mathrm{R})-9 \mathrm{ce})=3.29 \mathrm{~min}$.

Specific rotation: $[\alpha]_{\mathrm{D}}{ }^{20}-19.8^{\circ}\left(\mathrm{c} 0.68, \mathrm{CHCl}_{3}\right)$ for a sample containing a $96: 4$ mixture of 1,3-syn diastereomers ((1S,3R,7R,11R)-9ce :(1R,3S,7R,11R)-9ce)).

Specific rotation: $[\alpha]_{\mathrm{D}}^{20} 24.3^{\circ}\left(\mathrm{c} 0.47, \mathrm{CHCl}_{3}\right)$ for a sample containing a $4: 96$ mixture of 1,3-syn diastereomers ((1S,3R,7R,11R)-9ce :(1R,3S,7R,11R)-9ce)).

The absolute configuration was assigned by analogy to $9 \mathbf{a a}$. The absolute configuration was not further verified. 
(1S,3R,7R,11R)-1-(4-fluorophenyl)-3,7,11,15-tetramethylhexadecan-1-ol (9cf)

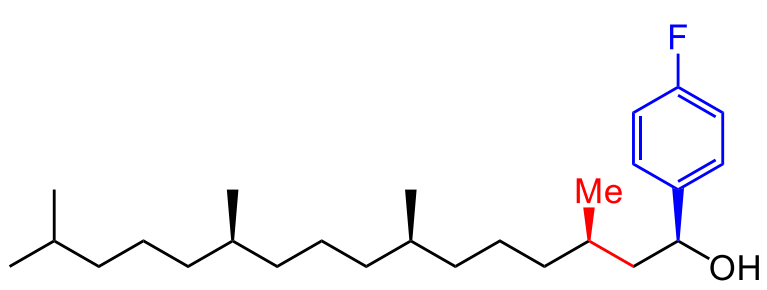

The compound 9cf was prepared according to General procedure 4 with (S,S)-Ru-1 and (S)- Ru-3 by reaction of (2E,7R,11R)-3,7,11,15-

tetramethylhexadec-2-en-1-ol $\quad(86 \mu \mathrm{L}$, $0.25 \mathrm{mmol}$ )with (4-fluorophenyl)boronic acid (105 mg, $0.75 \mathrm{mmol}$ ) and was isolated by column chromatography (silica gel, petroleum ether to petroleum ether/ethyl acetate 90:10) to give a transparent oil in $61 \%$ yield $(60 \mathrm{mg})$. The SFC analysis revealed that besides $(1 \mathrm{~S}, 3 \mathrm{R}, 7 \mathrm{R}, 11 \mathrm{R})-9 \mathrm{cf}$ product, the isolated material contained $1 \%$ of the other 1,3 -syn diastereomers of the product, i.e., $(1 \mathrm{R}, 3 \mathrm{~S}, 7 \mathrm{R}, 11 \mathrm{R})-9 \mathrm{cf}$. Independent synthesis of $(1 \mathrm{R}, 3 \mathrm{~S}, 7 \mathrm{R}, 11 \mathrm{R})-\mathbf{9 c f}$ as major diastereomer showed that both 1,3-syn diastereomers are indistinguishable by ${ }^{1} \mathrm{H}$ and ${ }^{13} \mathrm{C}$ NMR spectroscopy.

${ }^{1} \mathbf{H}$ NMR $\left(500 \mathrm{MHz}, \mathrm{CDCl}_{3}\right) \delta 7.35-7.28(\mathrm{~m}, 2 \mathrm{H}), 7.06-6.98(\mathrm{~m}, 2 \mathrm{H}), 4.76(\mathrm{dd}, J=9.3$, $4.4 \mathrm{~Hz}, 1 \mathrm{H}), 1.90-1.73(\mathrm{~m}, 2 \mathrm{H}), 1.67-1.59(\mathrm{~m}, 1 \mathrm{H}), 1.53(\mathrm{dp}, J=13.2,6.6 \mathrm{~Hz}, 1 \mathrm{H}), 1.41$ $-1.34(\mathrm{~m}, 3 \mathrm{H}), 1.31-1.22(\mathrm{~m}, 10 \mathrm{H}), 1.20-1.12(\mathrm{~m}, 4 \mathrm{H}), 1.10-1.01$ (m, 4H), 0.94 (d, $J$ $=6.6 \mathrm{~Hz}, 3 \mathrm{H}), 0.89-0.83(\mathrm{~m}, 12 \mathrm{H})$.

${ }^{13} \mathbf{C}\left\{{ }^{1} \mathbf{H}\right\}$ NMR $\left(126 \mathrm{MHz}, \mathrm{CDCl}_{3}\right) \delta 162.2(\mathrm{~d}, J=245.2 \mathrm{~Hz}), 141.4(\mathrm{~d}, J=3.1 \mathrm{~Hz}), 127.5$ $(\mathrm{d}, J=8.0 \mathrm{~Hz}), 115.4(\mathrm{~d}, J=21.3 \mathrm{~Hz}), 71.9(\mathrm{~d}, J=3.1 \mathrm{~Hz}), 47.2(\mathrm{~d}, J=0.8 \mathrm{~Hz}), 39.5,38.0$, 37.6, 37.44, 37.41, 33.0, 32.9, 29.6, 28.1, 25.0, 24.6, 24.4, 22.9, 22.8, 19.93, 19.89, 19.4.

${ }^{19} \mathbf{F}\left\{{ }^{1} \mathbf{H}\right\}$ NMR $\left(376 \mathrm{MHz}, \mathrm{CDCl}_{3}\right) \delta-115.37$.

HRMS (ESI) m/z: [M-H] $]^{+}$Calcd for $\mathrm{C}_{26} \mathrm{H}_{44} \mathrm{FO} 391.3371$; Found 391.3368 .

SFC with Chiralpak IG-3, 2\% MeOH / 98\% CO $2,1.2 \mathrm{~mL} / \mathrm{min}$, t(major, (1S,3R,7R,11R)9cf $)=3.32 \mathrm{~min}, \mathrm{t}(\operatorname{minor},(1 \mathrm{R}, 3 \mathrm{~S}, 7 \mathrm{R}, 11 \mathrm{R})-9 \mathbf{c f})=4.04 \mathrm{~min}$.

Specific rotation: $[\alpha]_{\mathrm{D}}{ }^{20}-11.2^{\circ}\left(\mathrm{c} 0.55, \mathrm{CHCl}_{3}\right)$ for a sample containing a 99 : 1 mixture of 1,3-syn diastereomers ((1S,3R,7R,11R)-9cf :(1R,3S,7R,11R)-9cf)).

Specific rotation: $[\alpha]_{\mathrm{D}}{ }^{20}+14.6^{\circ}\left(\mathrm{c} 0.55, \mathrm{CHCl}_{3}\right)$ for a sample containing a $2: 98$ mixture of 1,3-syn diastereomers ((1S,3R,7R,11R)-9cf :(1R,3S,7R,11R)-9cf)).

The absolute configuration was assigned by analogy to $9 \mathbf{a a}$. 
(1S,3R,7R,11R)-1-(4-chlorophenyl)-3,7,11,15-tetramethylhexadecan-1-ol (9cg)

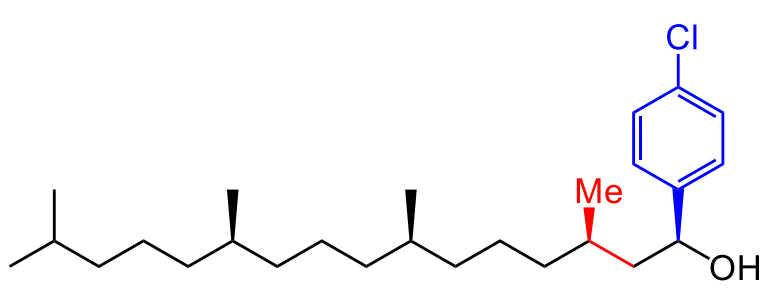

The compound 9cg was prepared according to General procedure 4 with (S,S)-Ru-1 and (S)- Ru-3 by reaction of (2E,7R,11R)-3,7,11,15tetramethylhexadec-2-en-1-ol $\quad(86 \mu \mathrm{L}$, $0.25 \mathrm{mmol}$ ) with (4-chlorophenyl)boronic acid $(110 \mathrm{mg}, 0.75 \mathrm{mmol})$ and was isolated by column chromatography (silica gel, petroleum ether to petroleum ether/ethyl acetate 90:10) to give a transparent oil in $44 \%$ yield $(45 \mathrm{mg})$. The SFC analysis revealed that besides (1S,3R,7R,11R)-9cg product, the isolated material contained $<1 \%$ of the other 1,3 -syn diastereomers of the product, i.e., $(1 \mathrm{R}, 3 \mathrm{~S}, 7 \mathrm{R}, 11 \mathrm{R})-\mathbf{9 c g}$. Independent synthesis of $(1 \mathrm{R}, 3 \mathrm{~S}, 7 \mathrm{R}, 11 \mathrm{R})-9 \mathrm{cg}$ as major diastereomer showed that both 1,3-syn diastereomers are indistinguishable by ${ }^{1} \mathrm{H}$ and ${ }^{13} \mathrm{C}$ NMR spectroscopy.

${ }^{1} \mathbf{H}$ NMR $\left(500 \mathrm{MHz}, \mathrm{CDCl}_{3}\right) \delta 7.37-7.26(\mathrm{~m}, 4 \mathrm{H}), 4.76(\mathrm{dd}, J=9.4,4.3 \mathrm{~Hz}, 1 \mathrm{H}), 1.82-$ $1.72(\mathrm{~m}, 2 \mathrm{H}), 1.68-1.61(\mathrm{~m}, 1 \mathrm{H}), 1.54-1.47(\mathrm{~m}, 1 \mathrm{H}), 1.41-1.34(\mathrm{~m}, 3 \mathrm{H}), 1.32-1.21$ (m, 10H), $1.21-1.11(\mathrm{~m}, 4 \mathrm{H}), 1.10-1.00(\mathrm{~m}, 4 \mathrm{H}), 0.94(\mathrm{~d}, J=6.6 \mathrm{~Hz}, 3 \mathrm{H}), 0.91-0.80$ (m, 12H).

${ }^{13} \mathbf{C}\left\{{ }^{1} \mathbf{H}\right\}$ NMR $\left(126 \mathrm{MHz}, \mathrm{CDCl}_{3}\right) \delta 144.1,133.2,128.7,127.3,71.9,47.1,39.5,38.0$, 37.63, 37.58, 37.4, 33.0, 32.9, 29.6, 28.1, 25.0, 24.6, 24.4, 22.9, 22.8, 19.86, 19.91, 19.4 .

HRMS (ESI) m/z: [M-H] $]^{+}$Calcd for $\mathrm{C}_{26} \mathrm{H}_{44} \mathrm{ClO}$ 407.3075; Found 407.3073.

SFC with Chiralpak IG-3, 3\% MeOH / 97\% CO $2,1.2 \mathrm{~mL} / \mathrm{min}$, t(minor, (1R,3S,7R,11R)$\mathbf{9 c g})=4.94 \mathrm{~min}, \mathrm{t}($ major, $(1 \mathrm{~S}, 3 \mathrm{R}, 7 \mathrm{R}, 11 \mathrm{R})-\mathbf{9 c g})=5.40 \mathrm{~min}$.

Specific rotation: $[\alpha]_{\mathrm{D}}^{20}-9.4^{\circ}\left(\mathrm{c} 0.59, \mathrm{CHCl}_{3}\right)$ for a sample containing a $>99:<1$ mixture of 1,3-syn diastereomers ((1S,3R,7R,11R)-9cg :(1R,3S,7R,11R)-9cg)).

Specific rotation: $[\alpha]_{\mathrm{D}^{20}}+10.5^{\circ}\left(\mathrm{c} 0.51, \mathrm{CHCl}_{3}\right)$ for a sample containing a $2: 98$ mixture of 1,3-syn diastereomers ((1S,3R,7R,11R)-9cg :(1R,3S,7R,11R)-9cg)).

The absolute configuration was assigned by analogy to $9 \mathbf{a a}$. The absolute configuration was not further verified. 
(1S,3R,7R,11R)-3,7,11,15-tetramethyl-1-(naphthalen-2-yl)hexadecan-1-ol (9ch)

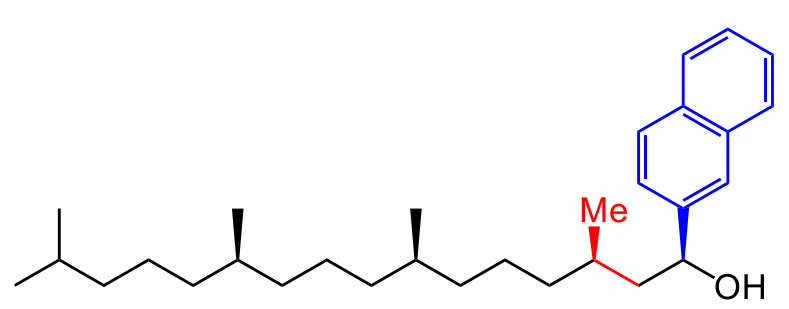

The compound 9ch was prepared according to General procedure 4 with (S,S)-Ru-1 and (S)- Ru-3 by reaction of (2E,7R,11R)-3,7,11,15tetramethylhexadec-2-en-1-ol $\quad(86 \mu \mathrm{L}$, $0.25 \mathrm{mmol}$ )with naphthalen-2-ylboronic acid $(129 \mathrm{mg}, 0.75 \mathrm{mmol})$ and was isolated by column chromatography (silica gel, petroleum ether to petroleum ether/ethyl acetate 90:10) to give a white solid in $48 \%$ yield $(51 \mathrm{mg})$. The SFC analysis revealed that besides $(1 \mathrm{~S}, 3 \mathrm{R}, 7 \mathrm{R}, 11 \mathrm{R})-9 \mathrm{ch}$ product, the isolated material contained $1 \%$ of the other 1,3-syn diastereomers of the product, i.e., $(1 \mathrm{R}, 3 \mathrm{~S}, 7 \mathrm{R}, 11 \mathrm{R})-\mathbf{9} \mathrm{ch}$. Independent synthesis of $(1 \mathrm{R}, 3 \mathrm{~S}, 7 \mathrm{R}, 11 \mathrm{R})-9 \mathrm{ch}$ as major diastereomer showed that both 1,3-syn diastereomers are indistinguishable by ${ }^{1} \mathrm{H}$ and ${ }^{13} \mathrm{C}$ NMR spectroscopy.

${ }^{1} \mathbf{H}$ NMR $\left(500 \mathrm{MHz}, \mathrm{CDCl}_{3}\right) \delta 7.86-7.81(\mathrm{~m}, 3 \mathrm{H}), 7.80(\mathrm{~s}, 1 \mathrm{H}), 7.51-7.44(\mathrm{~m}, 3 \mathrm{H}), 4.95$ (dd, $J=9.3,4.4 \mathrm{~Hz}, 1 \mathrm{H}), 1.95-1.81(\mathrm{~m}, 2 \mathrm{H}), 1.74-1.66(\mathrm{~m}, 1 \mathrm{H}), 1.59-1.47(\mathrm{~m}, 3 \mathrm{H})$, $1.35-1.22(\mathrm{~m}, 10 \mathrm{H}), 1.21-1.11(\mathrm{~m}, 4 \mathrm{H}), 1.10-1.01(\mathrm{~m}, 4 \mathrm{H}), 0.98(\mathrm{~d}, J=6.6 \mathrm{~Hz}, 3 \mathrm{H})$, $0.91-0.79(\mathrm{~m}, 12 \mathrm{H})$.

${ }^{13} \mathbf{C}\left\{{ }^{1} \mathbf{H}\right\}$ NMR $\left(126 \mathrm{MHz}, \mathrm{CDCl}_{3}\right) \delta$ 143.0, 133.5, 133.1, 128.4, 128.0, 127.8, 126.3, 125.9, 124.4, 124.2, 72.7, 47.0, 39.5, 38.1, 37.6, 37.44, 37.38, 33.0, 32.9, 29.7, 28.1, 25.0, 24.6, 24.4, 22.9, 22.8, 19.93, 19.91, 19.5 .

HRMS (ESI) m/z: [M-H] $]^{+}$Calcd for $\mathrm{C}_{30} \mathrm{H}_{47} \mathrm{O}$ 423.3621; Found 423.3619.

SFC with Chiralpak IG-3, 5\% iPrOH / 95\% CO $2,1.2 \mathrm{~mL} / \mathrm{min}$, t(major, (1S,3R,7R,11R)9ch $)=5.43 \mathrm{~min}, \mathrm{t}(\mathrm{minor},(1 \mathrm{R}, 3 \mathrm{~S}, 7 \mathrm{R}, 11 \mathrm{R})-9 \mathrm{ch})=6.35 \mathrm{~min}$.

Specific rotation: $[\alpha]_{\mathrm{D}}^{20}-20.0^{\circ}\left(\mathrm{c} 0.6, \mathrm{CHCl}_{3}\right)$ for a sample containing a $99: 1$ mixture of 1,3-syn diastereomers ((1S,3R,7R,11R)-9ch :(1R,3S,7R,11R)-9ch)).

Specific rotation: $[\alpha]_{\mathrm{D}}{ }^{20}+20.0^{\circ}\left(\mathrm{c} 0.74, \mathrm{CHCl}_{3}\right)$ for a sample containing a $1: 99$ mixture of 1,3-syn diastereomers ((1S,3R,7R,11R)-9ch :(1R,3S,7R,11R)-9ch)).

The absolute configuration was assigned by analogy to $9 \mathbf{a a}$. The absolute configuration was not further verified. 
(1S,3R,7R,11R)-3,7,11,15-tetramethyl-1-(m-tolyl)hexadecan-1-ol (9ci)

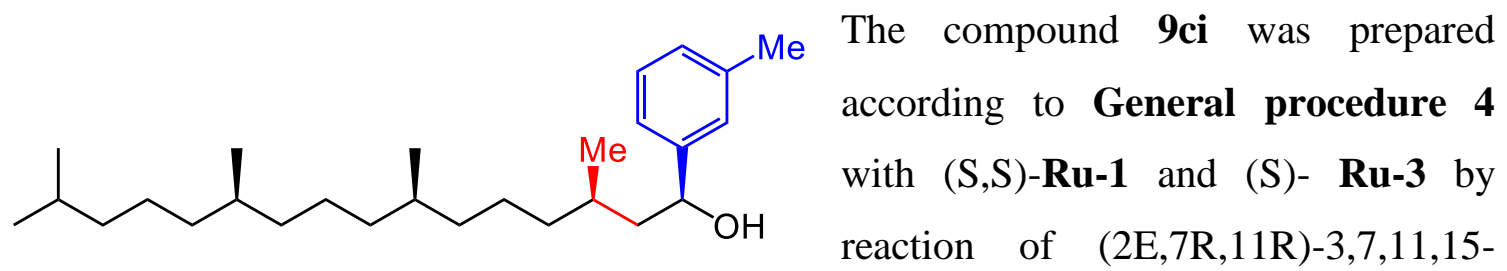

tetramethylhexadec-2-en-1-ol ( $86 \mu \mathrm{L}, 0.25 \mathrm{mmol})$ with $m$-tolylboronic acid (102 $\mathrm{mg}, 0.75$ mmol) and was isolated by column chromatography (silica gel, petroleum ether to petroleum ether/ethyl acetate 90:10) to give a transparent oil in 69\% yield $(67 \mathrm{mg})$. The SFC analysis revealed that besides (1S,3R,7R,11R)-9ci product, the isolated material contained $<1 \%$ of the other 1,3-syn diastereomers of the product, i.e., (1R,3S,7R,11R)-9ci. Independent synthesis of (1R,3S,7R,11R)-9ci as major diastereomer showed that both 1,3syn diastereomers are indistinguishable by ${ }^{1} \mathrm{H}$ and ${ }^{13} \mathrm{C}$ NMR spectroscopy.

${ }^{1} \mathbf{H}$ NMR $\left(500 \mathrm{MHz}, \mathrm{CDCl}_{3}\right) \delta 7.24(\mathrm{t}, J=7.5 \mathrm{~Hz}, 1 \mathrm{H}), 7.19-7.12(\mathrm{~m}, 2 \mathrm{H}), 7.09(\mathrm{~d}, J=$ $7.4 \mathrm{~Hz}, 1 \mathrm{H}), 4.75$ (dd, $J=9.4,4.2 \mathrm{~Hz}, 1 \mathrm{H}), 2.36(\mathrm{~s}, 3 \mathrm{H}), 1.85-1.72(\mathrm{~m}, 2 \mathrm{H}), 1.70-1.62$ (m, 1H), $1.53(\mathrm{dp}, J=13.3,6.6 \mathrm{~Hz}, 1 \mathrm{H}), 1.44-1.35(\mathrm{~m}, 3 \mathrm{H}), 1.32-1.23(\mathrm{~m}, 10 \mathrm{H}), 1.20$ $-1.11(\mathrm{~m}, 4 \mathrm{H}), 1.11-1.01(\mathrm{~m}, 4 \mathrm{H}), 0.96(\mathrm{~d}, J=6.6 \mathrm{~Hz}, 3 \mathrm{H}), 0.89-0.82(\mathrm{~m}, 12 \mathrm{H})$.

${ }^{13} \mathbf{C}\left\{{ }^{1} \mathbf{H}\right\}$ NMR $\left(126 \mathrm{MHz}, \mathrm{CDCl}_{3}\right) \delta$ 145.7, 138.3, 128.5, 128.3, 126.6, 122.9, 72.5, 47.1, $39.5,38.1,37.61,37.56,37.4,33.0,32.9,29.6,28.1,25.0,24.6,24.4,22.9,22.8,21.6$, 19.91, 19.86, 19.4.

HRMS (ESI) m/z: [M-H] $]^{+}$Calcd for $\mathrm{C}_{27} \mathrm{H}_{47} \mathrm{O}$ 387.3621; Found 387.3625.

SFC with Chiralpak IG-3, 3\% MeOH / 97\% CO $2,1.2 \mathrm{~mL} / \mathrm{min}$, t(major, (1S,3R,7R,11R)9ci $)=2.70 \mathrm{~min}, \mathrm{t}(\operatorname{minor},(1 \mathrm{R}, 3 \mathrm{~S}, 7 \mathrm{R}, 11 \mathrm{R})-9 \mathrm{ci})=4.52 \mathrm{~min}$.

Specific rotation: $[\alpha]_{\mathrm{D}^{20}}-26.1^{\circ}\left(\mathrm{c} 0.86, \mathrm{CHCl}_{3}\right)$ for a sample containing a $>99$ : $<1$ mixture of 1,3-syn diastereomers ((1S,3R,7R,11R)-9ci :(1R,3S,7R,11R)-9ci)).

Specific rotation: $[\alpha]_{\mathrm{D}^{20}}+20.8^{\circ}\left(\mathrm{c} 0.65, \mathrm{CHCl}_{3}\right)$ for a sample containing a $<1$ : $>99$ mixture of 1,3-syn diastereomers ((1S,3R,7R,11R)-9ci :(1R,3S,7R,11R)-9ci)).

The absolute configuration was assigned by analogy to $9 \mathbf{a a}$. The absolute configuration was not further verified. 
(1S,3R,7R,11R)-1-(3-chlorophenyl)-3,7,11,15-tetramethylhexadecan-1-ol (9cj)

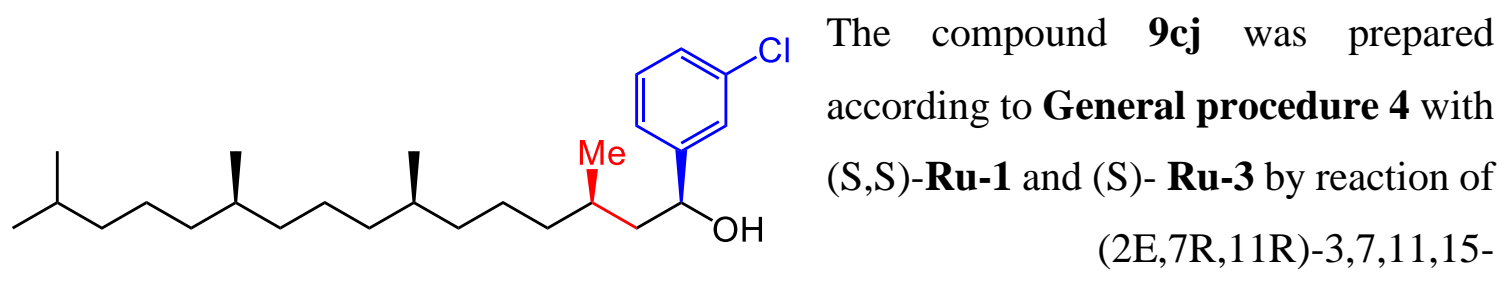

tetramethylhexadec-2-en-1-ol ( $86 \mu \mathrm{L}, 0.25 \mathrm{mmol}$ ) with (3-chlorophenyl)boronic acid (110 $\mathrm{mg}, 0.75 \mathrm{mmol}$ ) and was isolated by column chromatography (silica gel, petroleum ether to petroleum ether/ethyl acetate 90:10) to give a pale yellow oil in $47 \%$ yield $(48 \mathrm{mg})$. The SFC analysis revealed that besides $(1 \mathrm{~S}, 3 \mathrm{R}, 7 \mathrm{R}, 11 \mathrm{R})-9 \mathrm{cj}$ product, the isolated material contained $1.5 \%$ of the other 1,3-syn diastereomers of the product, i.e., (1R,3S,7R,11R)9cj. Independent synthesis of (1R,3S,7R,11R)-9cj as major diastereomer showed that both 1,3-syn diastereomers are indistinguishable by ${ }^{1} \mathrm{H}$ and ${ }^{13} \mathrm{C}$ NMR spectroscopy.

${ }^{1} \mathbf{H}$ NMR $\left(500 \mathrm{MHz}, \mathrm{CDCl}_{3}\right) \delta 7.33(\mathrm{t}, J=1.9 \mathrm{~Hz}, 1 \mathrm{H}), 7.25-7.17$ (m, 3H), $4.73(\mathrm{dd}, J=$ 9.5, 4.1 Hz, 1H), $1.85-1.70(\mathrm{~m}, 2 \mathrm{H}), 1.67-1.59(\mathrm{~m}, 1 \mathrm{H}), 1.50(\mathrm{dp}, J=13.3,6.6 \mathrm{~Hz}, 1 \mathrm{H})$, $1.40-1.32(\mathrm{~m}, 3 \mathrm{H}), 1.30-1.19(\mathrm{~m}, 10 \mathrm{H}), 1.19-1.09(\mathrm{~m}, 4 \mathrm{H}), 1.08-0.98(\mathrm{~m}, 4 \mathrm{H}), 0.93$ (d, $J=6.6 \mathrm{~Hz}, 3 \mathrm{H}), 0.83(\mathrm{dd}, J=11.1,6.6 \mathrm{~Hz}, 12 \mathrm{H})$.

${ }^{13} \mathbf{C}\left\{{ }^{1} \mathbf{H}\right\}$ NMR $\left(126 \mathrm{MHz}, \mathrm{CDCl}_{3}\right) \delta$ 147.8, 134.5, 129.9, 127.6, 126.1, 124.0, 71.9, 47.1, 39.5, 38.0, 37.61, 37.60, 37.4, 33.0, 32.9, 29.6, 28.1, 25.0, 24.6, 24.4, 22.9, 22.8, 19.91, $19.87,19.4$.

HRMS (ESI) m/z: [M-H] ${ }^{+}$Calcd for $\mathrm{C}_{26} \mathrm{H}_{44} \mathrm{ClO}$ 407.3075; Found 407.3080.

SFC with Chiralpak IA-3, 3\% MeOH / 97\% CO, $1.2 \mathrm{~mL} / \mathrm{min}$, t(minor, (1R,3S,7R,11R)9cj) $=3.86 \mathrm{~min}, \mathrm{t}($ major, $(1 \mathrm{~S}, 3 \mathrm{R}, 7 \mathrm{R}, 11 \mathrm{R})-\mathbf{9} \mathbf{c j})=4.38 \mathrm{~min}$.

Specific rotation: $[\alpha]_{\mathrm{D}}{ }^{20}-22.6^{\circ}$ (c $\left.0.58, \mathrm{CHCl}_{3}\right)$ for a sample containing a $98.5: 1.5$ mixture of 1,3-syn diastereomers ((1S,3R,7R,11R)-9cj :(1R,3S,7R,11R)-9cj)).

Specific rotation: $[\alpha]_{\mathrm{D}}^{20}+18.2^{\circ}\left(\mathrm{c} 0.53, \mathrm{CHCl}_{3}\right)$ for a sample containing a $0.5: 99.5$ mixture of 1,3-syn diastereomers ((1S,3R,7R,11R)-9cj :(1R,3S,7R,11R)-9cj)).

The absolute configuration was assigned by analogy to $9 \mathbf{a a}$. The absolute configuration was not further verified. 
(1S,3S)-3-((R)-4-methylcyclohex-3-en-1-yl)-1-phenylbutan-1-ol (9da)

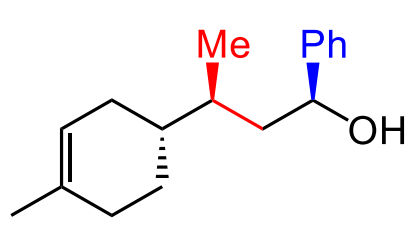

The compound 9da was prepared was prepared according to General procedure 4 with (S,S)-Ru-1 and (S)- Ru-3 (the reaction time of the isomerization step is $2 \mathrm{~h}$ ) by reaction of (E)3-(4-methylcyclohex-3-en-1-yl)but-2-en-1-ol (21 mg, 0.125 mmol) with phenylboronic acid (45 $\mathrm{mg}, 0.375 \mathrm{mmol}$ ) and was isolated by column chromatography (silica gel, petroleum ether to petroleum ether/ethyl acetate 90:10) to give a transparent oil in $41 \%$ yield (13 mg) with $\mathrm{dr}>20: 1 . *$

*No other diasteromers were observed by the GC-MS and ${ }^{1} \mathrm{H}$ NMR analyses for either the isolated material or in the reaction mixture.

${ }^{1} \mathbf{H}$ NMR (500 MHz, $\left.\mathrm{CDCl}_{3}\right) \delta 7.40$ - 7.32 (m, 4H), 7.29 - 7.26 (m, 1H), 5.37 (bs, 1H), $4.77(\mathrm{dt}, \mathrm{J}=9.8,3.5 \mathrm{~Hz}, 1 \mathrm{H}), 2.00-1.83(\mathrm{~m}, 3 \mathrm{H}), 1.83-1.77(\mathrm{~m}, 1 \mathrm{H}), 1.77-1.66(\mathrm{~m}$, $3 \mathrm{H}), 1.63(\mathrm{~s}, 3 \mathrm{H}), 1.48-1.37(\mathrm{~m}, 2 \mathrm{H}), 1.35-1.22(\mathrm{~m}, 2 \mathrm{H}), 0.94(\mathrm{~d}, \mathrm{~J}=6.9 \mathrm{~Hz}, 3 \mathrm{H})$.

${ }^{13} \mathbf{C}\left\{{ }^{1} \mathbf{H}\right\}$ NMR $\left(126 \mathrm{MHz}, \mathrm{CDCl}_{3}\right) \delta 145.9,134.2,128.6,127.6,125.9,121.1,72.6,44.5$, 39.2, 33.9, 31.2, 27.9, 27.1, 23.6, 15.8 .

HRMS (ESI) m/z: [M-H] $]^{+}$Calcd for $\mathrm{C}_{17} \mathrm{H}_{23} \mathrm{O}$ 243.1743; Found 243.1753.

Specific rotation: $[\alpha]_{\mathrm{D}}^{20}+2^{\circ}\left(\mathrm{c} 0.27, \mathrm{CHCl}_{3}\right)$ for a sample containing a single diastereomer (> dr 20:1 by the GC-MS and ${ }^{1} \mathrm{H}$ NMR analyses).

The absolute configuration was assigned by analogy to 9aa. 


\section{${ }^{1} \mathrm{H}$ AND ${ }^{13} \mathrm{C}$ NMR SPECTRA}

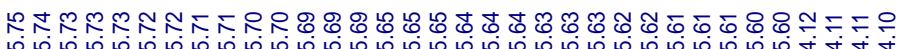

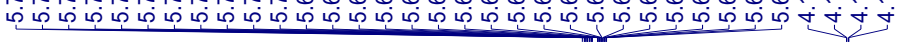

䒿蔡<smiles>CC(C)(C)CC=CCO</smiles>

(E)-5,5-dimethylhex-2-en-1-ol (S3)

${ }^{1} \mathrm{H}$ NMR (500 MHz, $\mathrm{CDCl}_{3}$ )

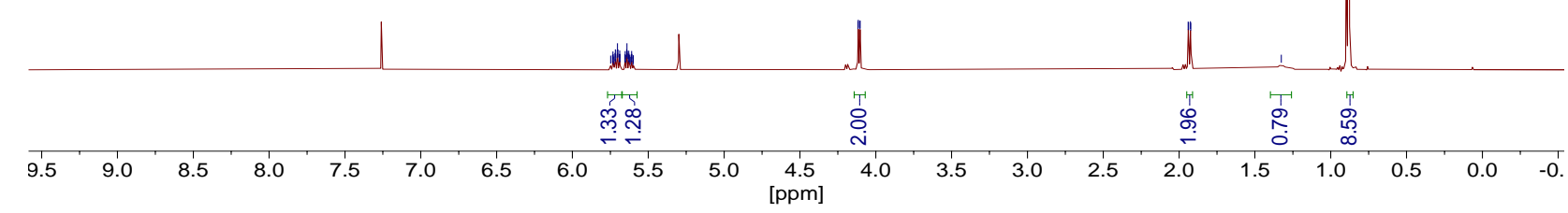

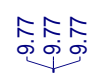

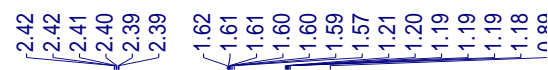
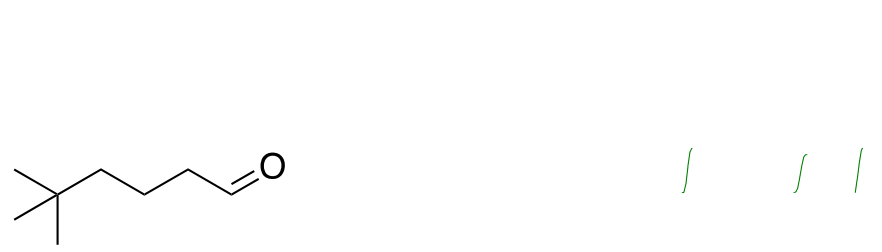

5,5-dimethylhexanal (S4)

${ }^{1} \mathrm{H}$ NMR (500 MHz, $\mathrm{CDCl}_{3}$ )

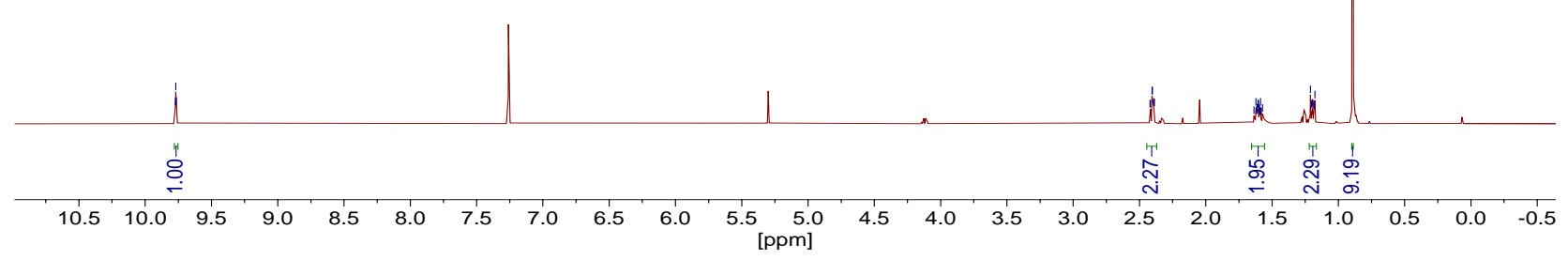




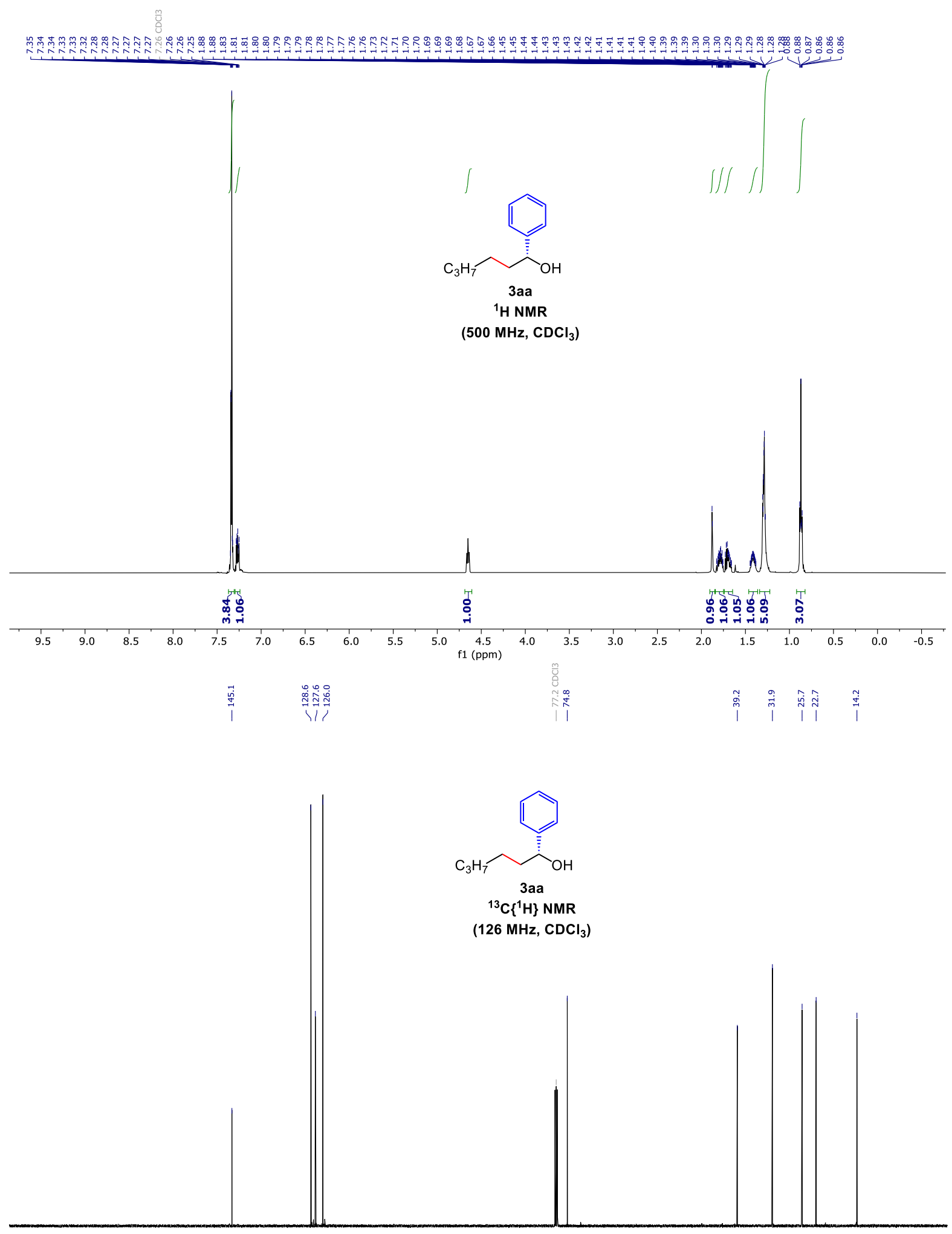

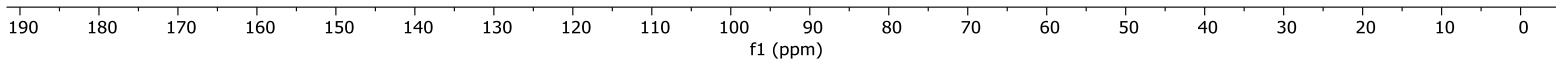




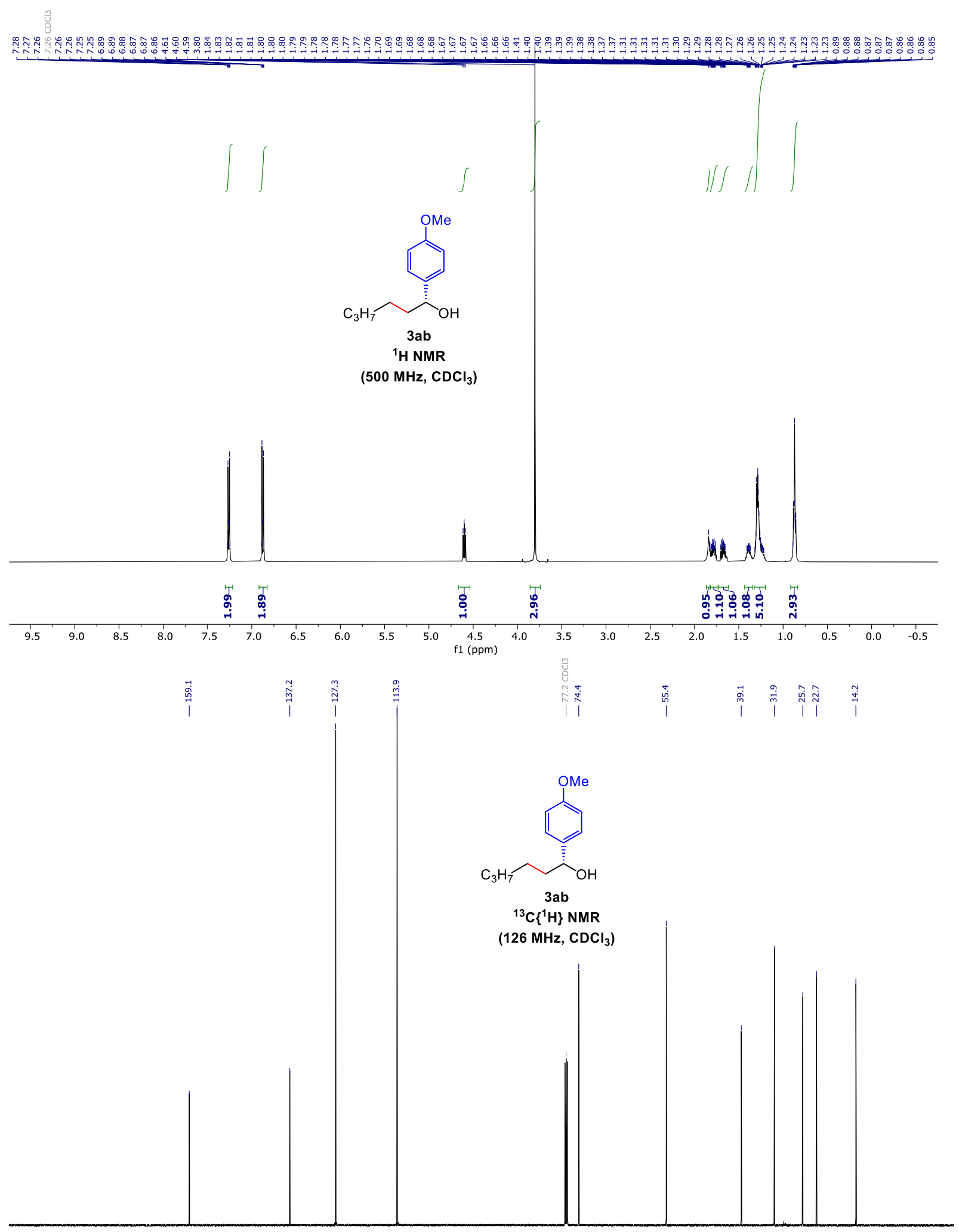

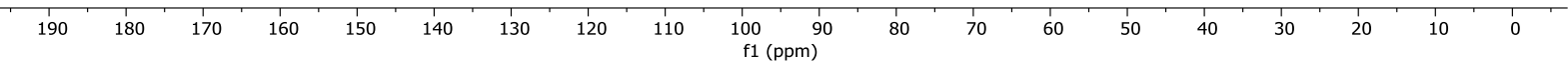



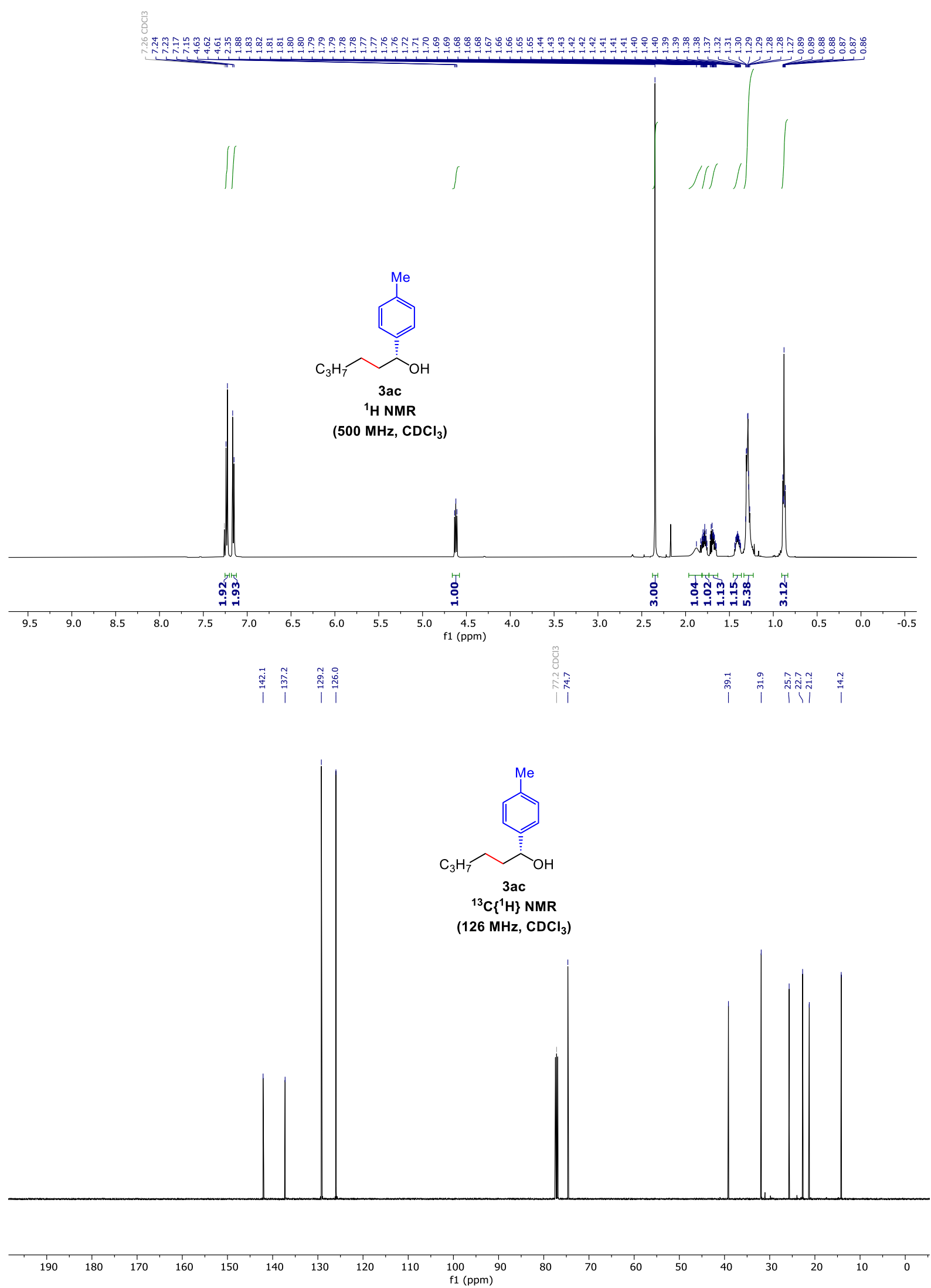


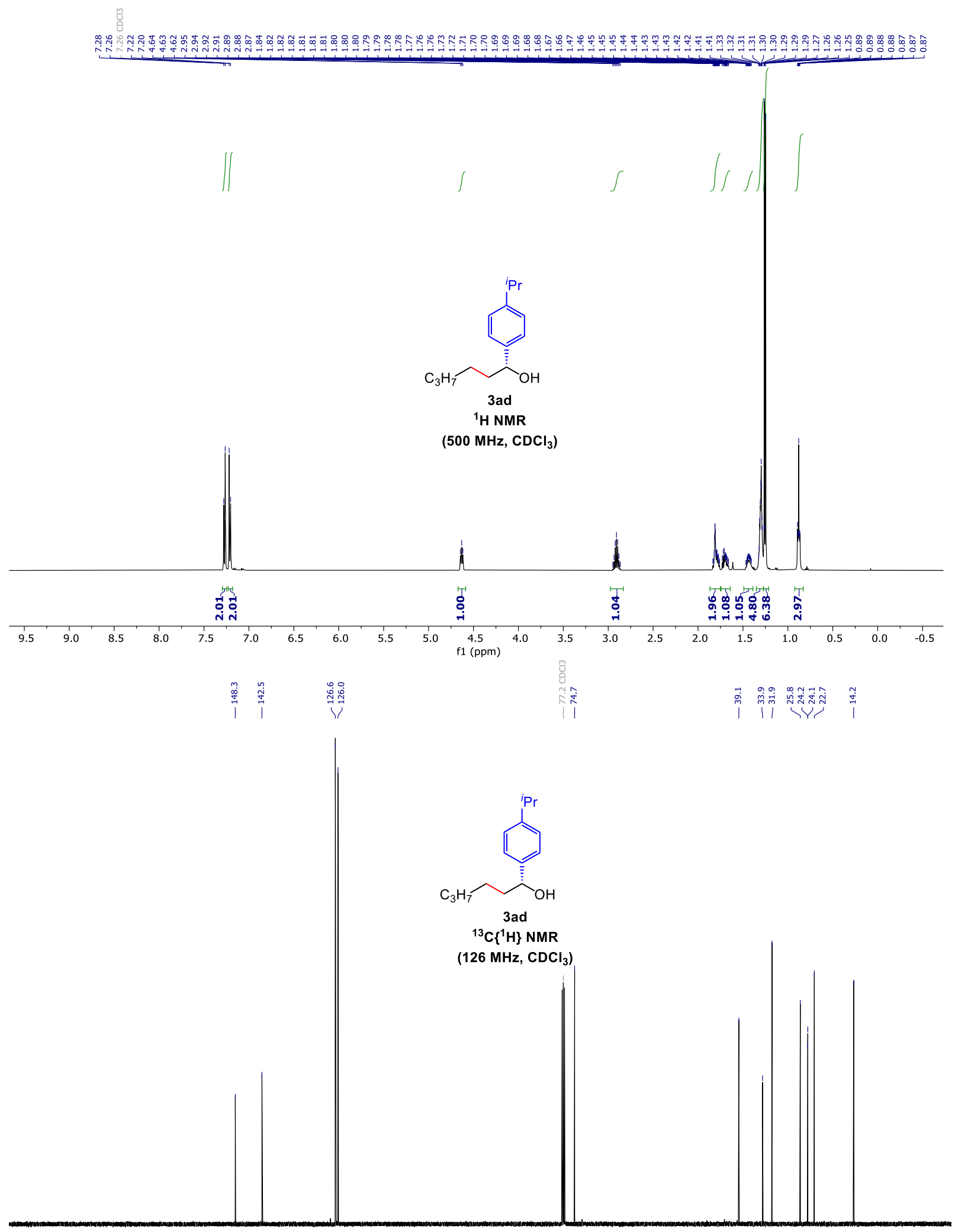

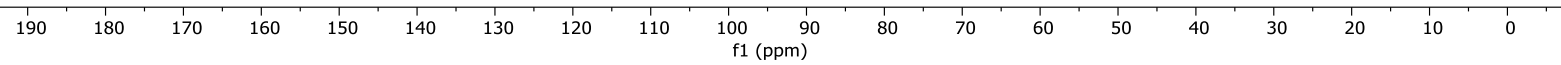




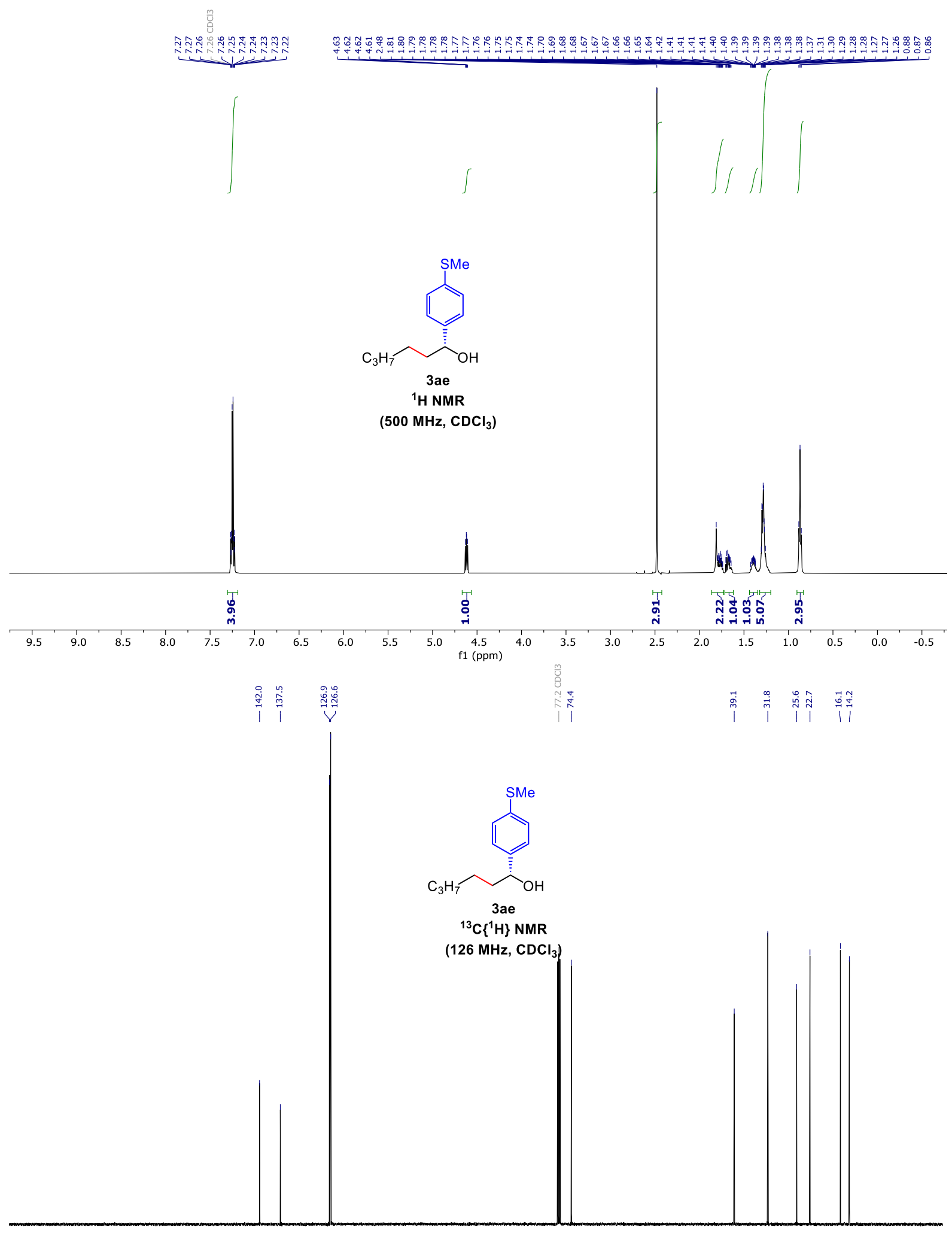

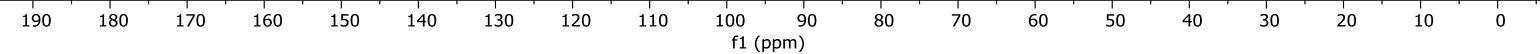



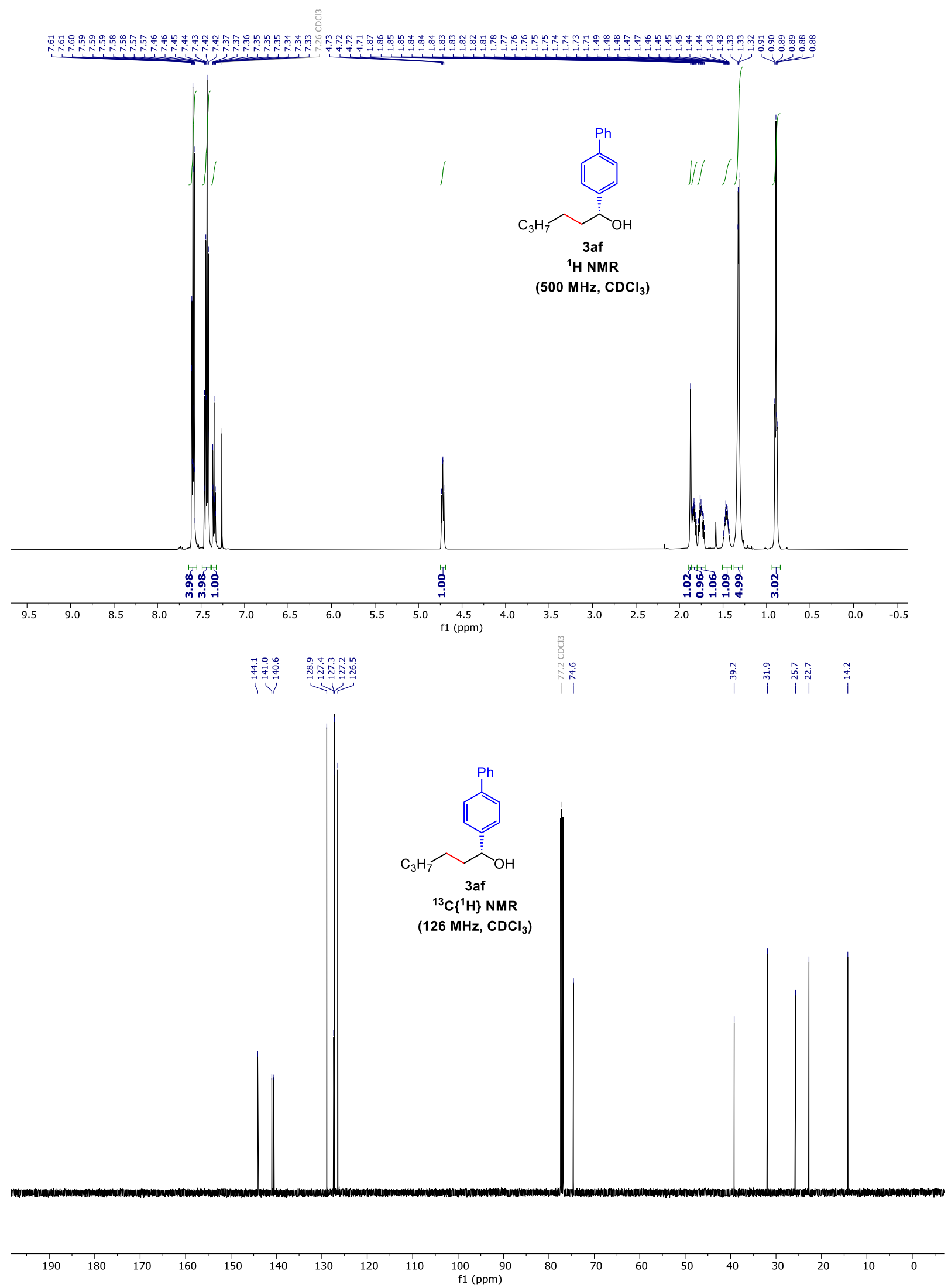


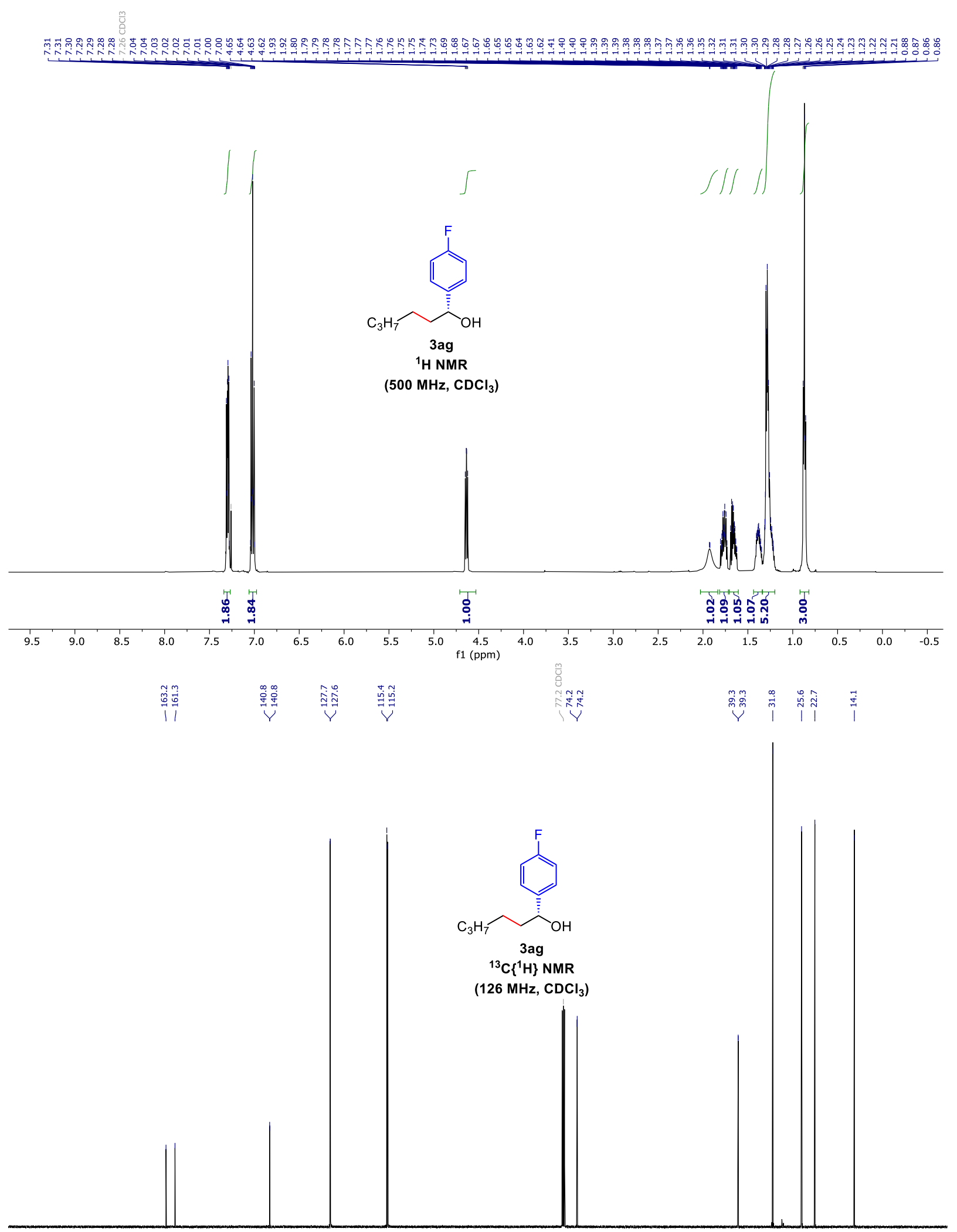

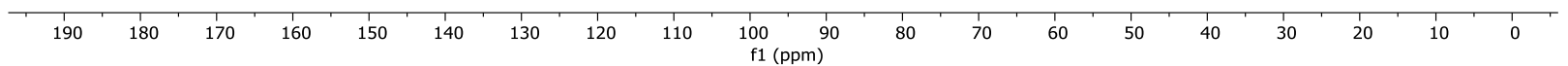




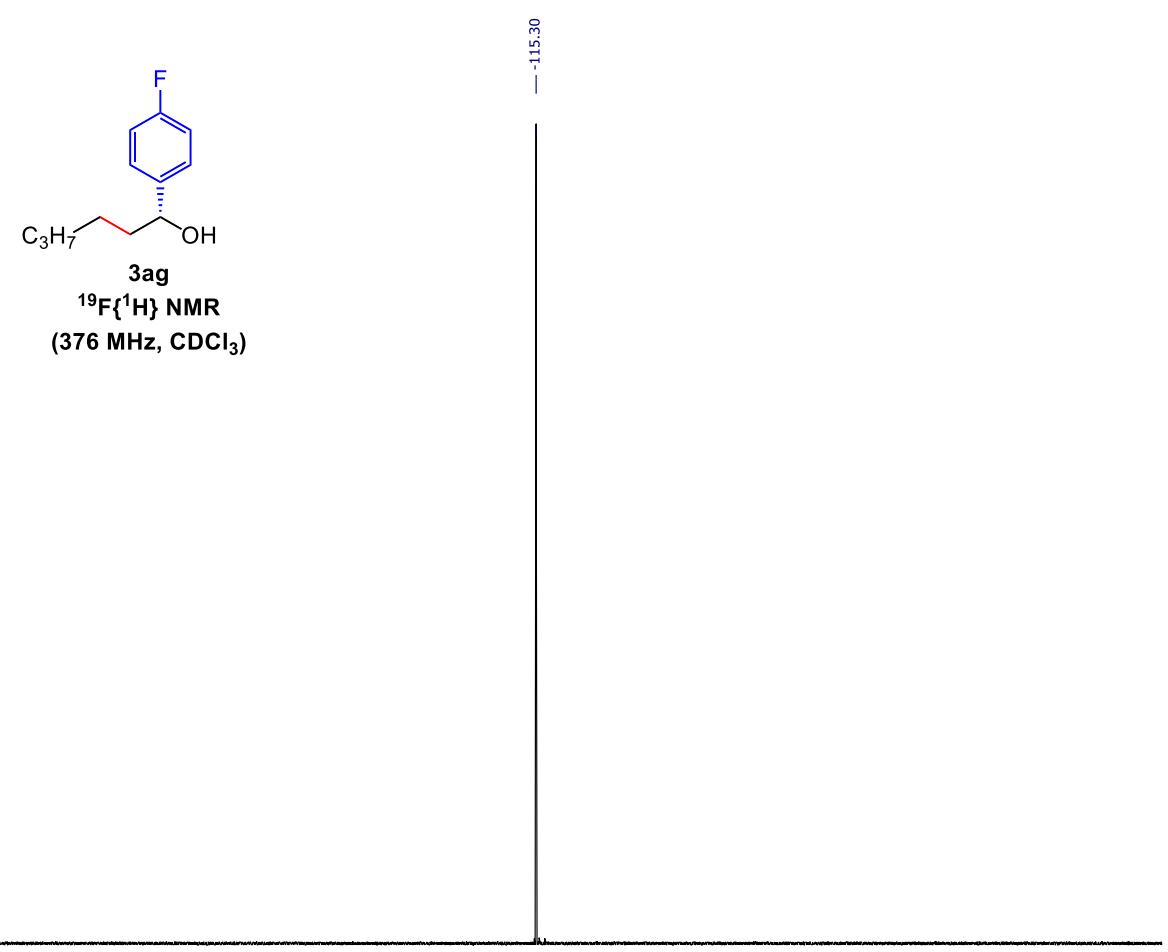

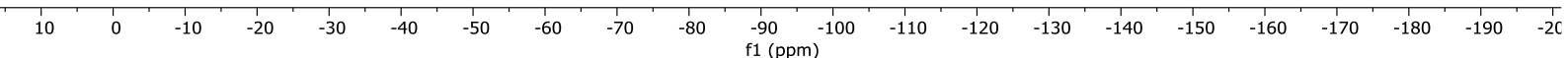



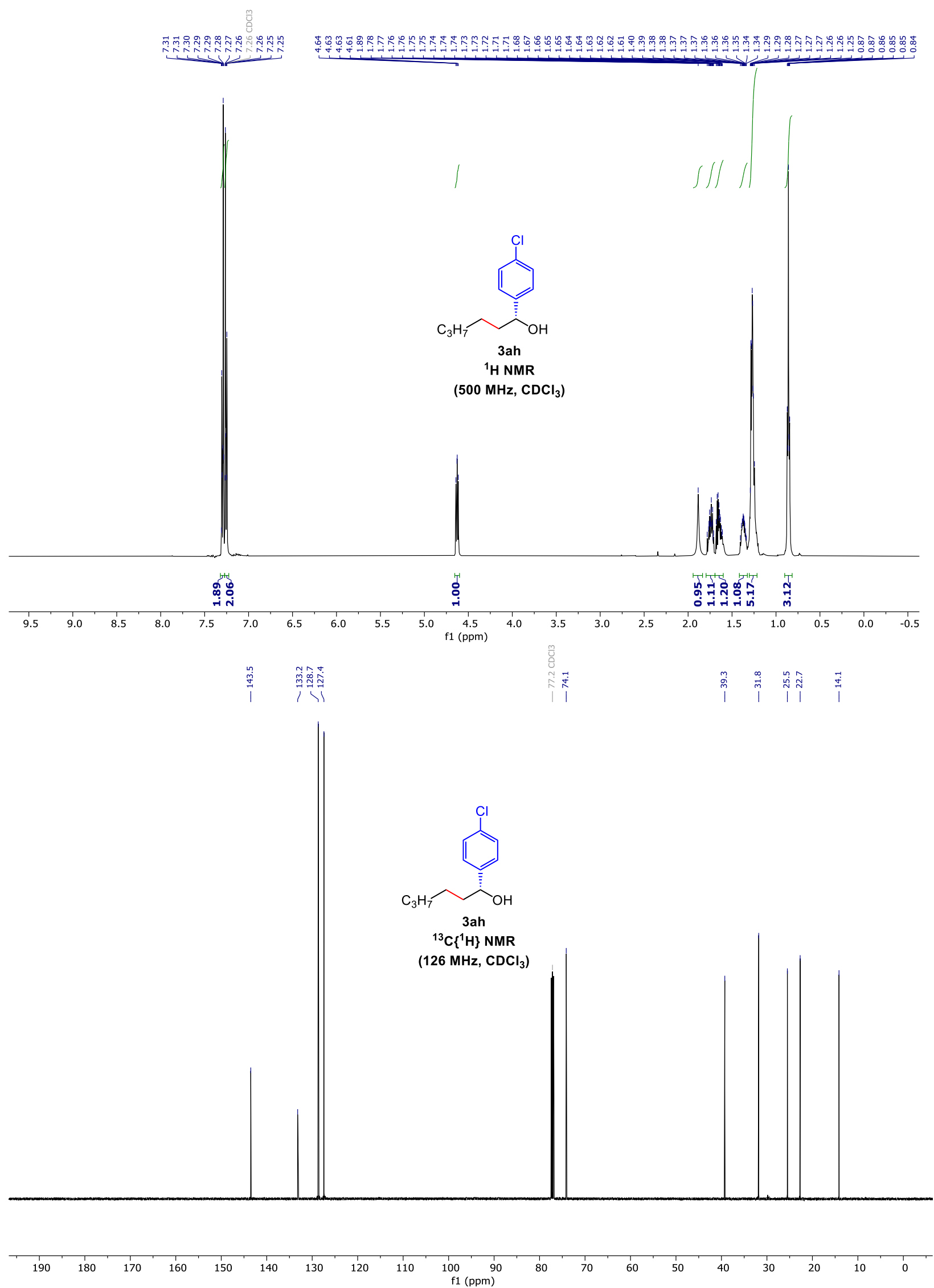


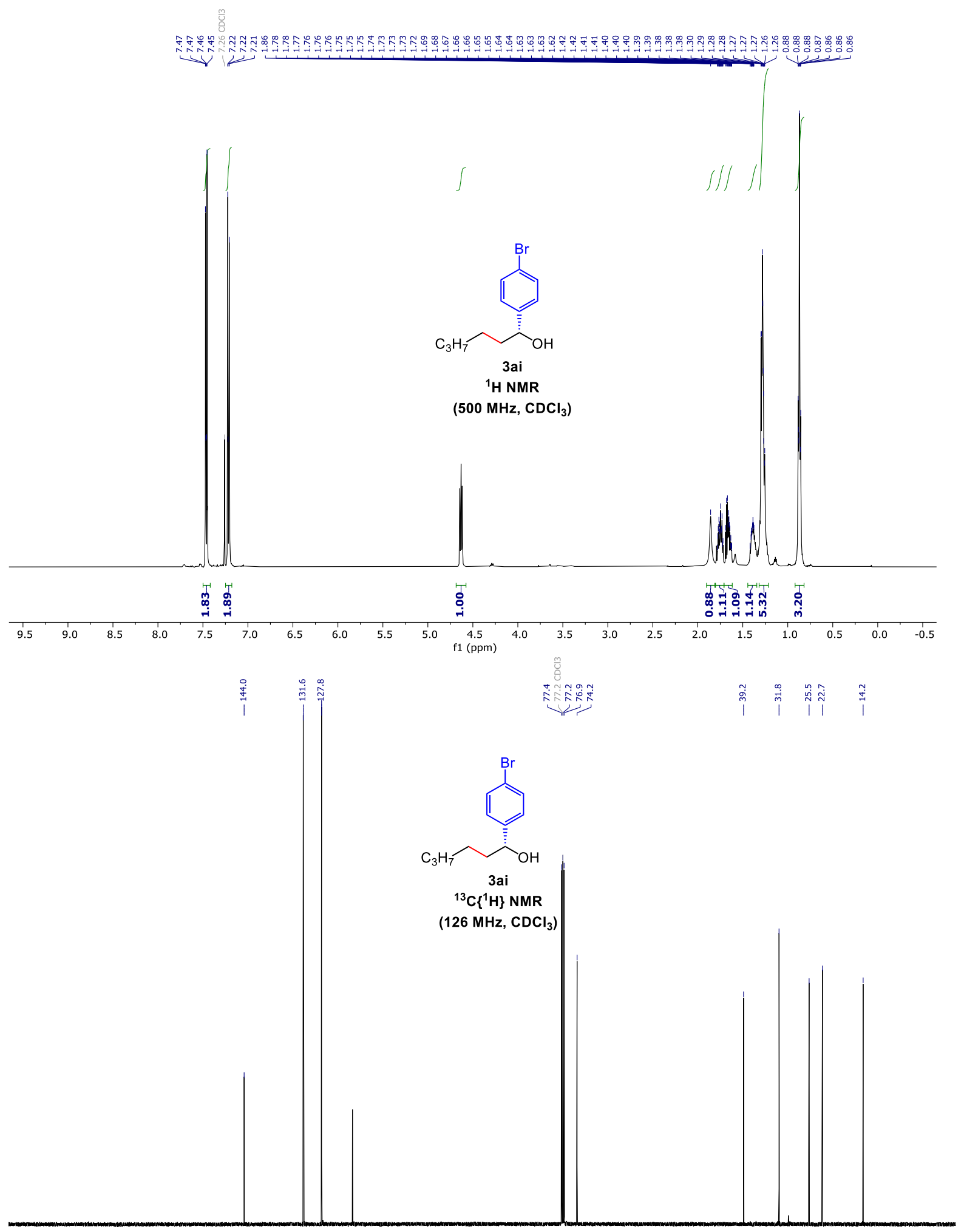

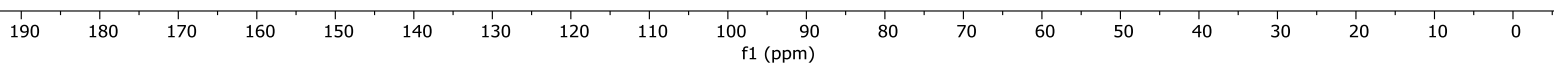



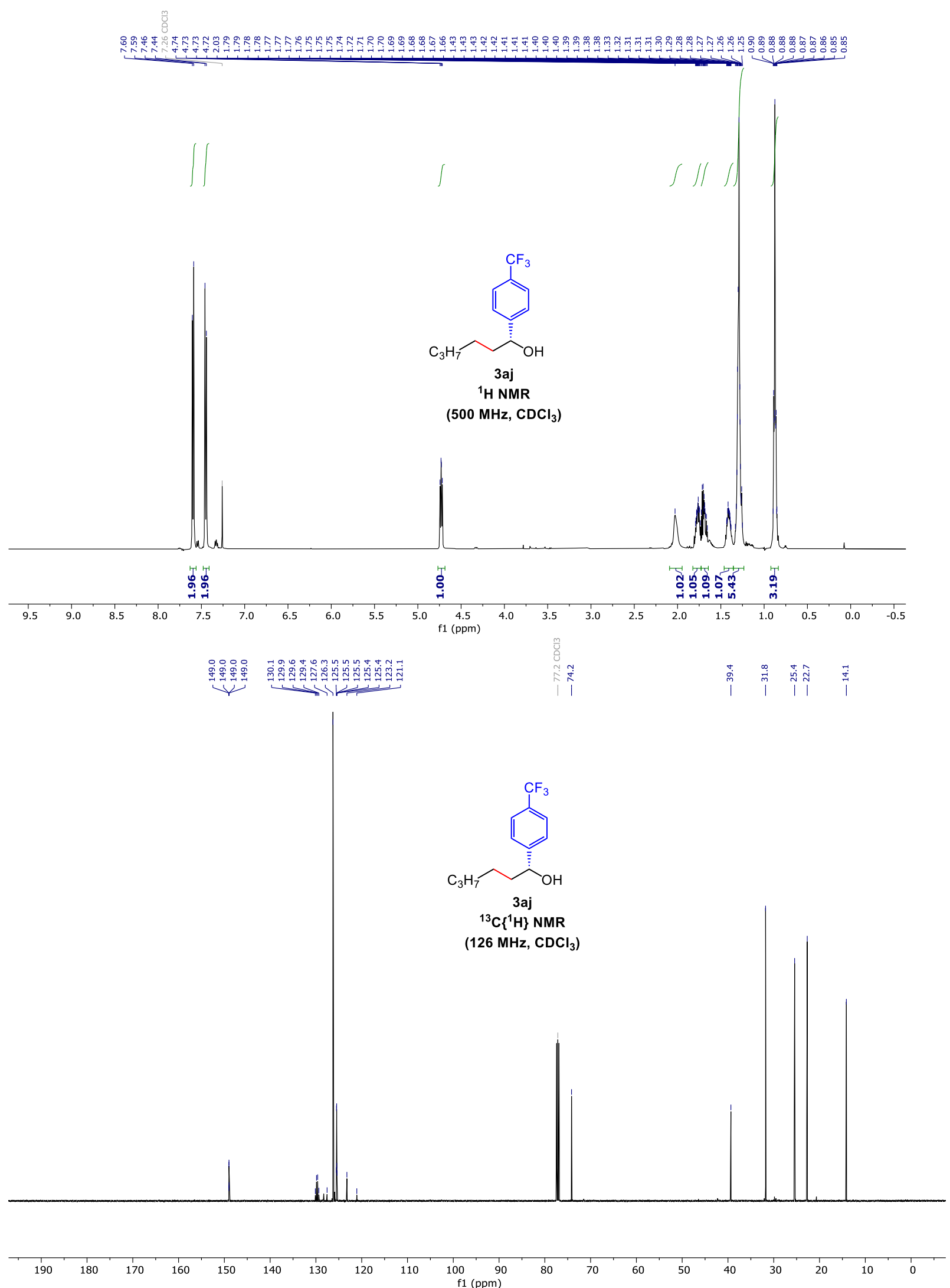


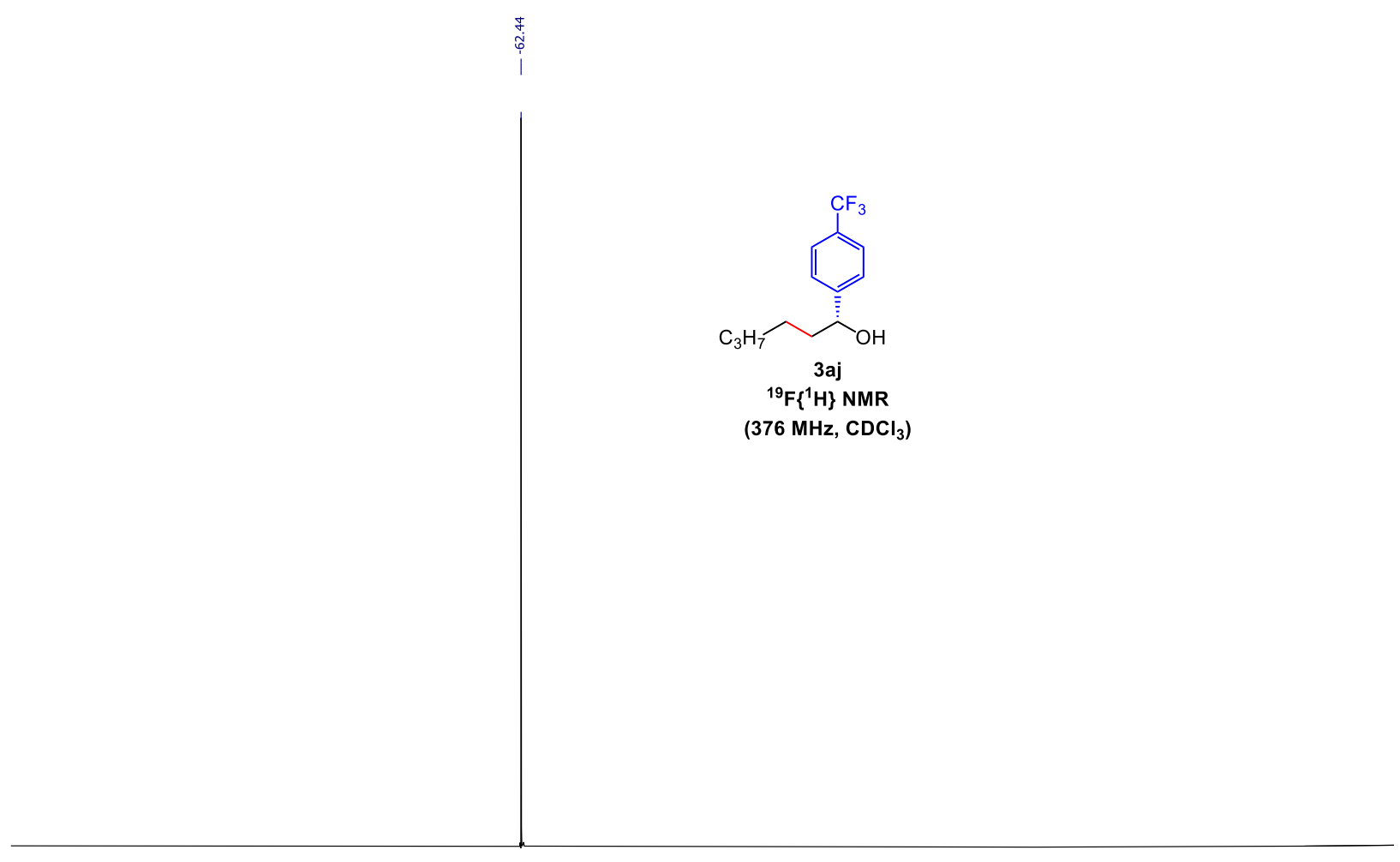

$\begin{array}{llllllllllllllllllllllllll}20 & 10 & 0 & -10 & -20 & -30 & -40 & -50 & -60 & -70 & -80 & -90 & -100 & -110 & -120 & -130 & -140 & -150 & -160 & -170 & -180 & -190 & -200\end{array}$ 

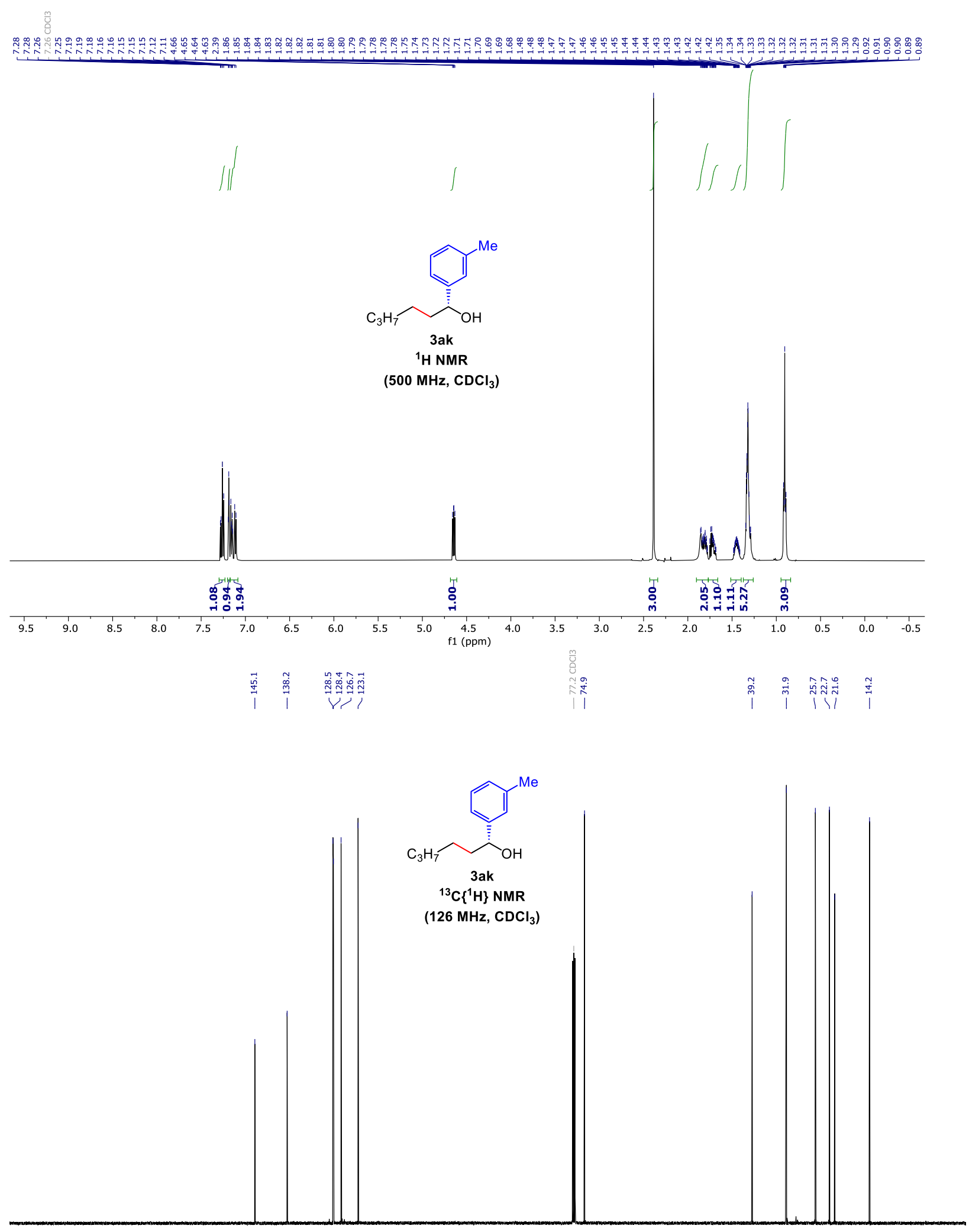

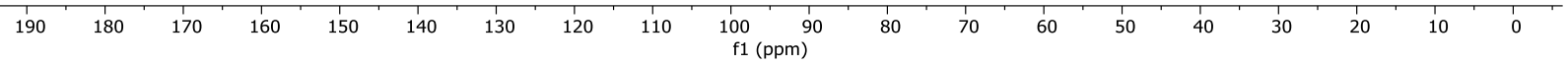



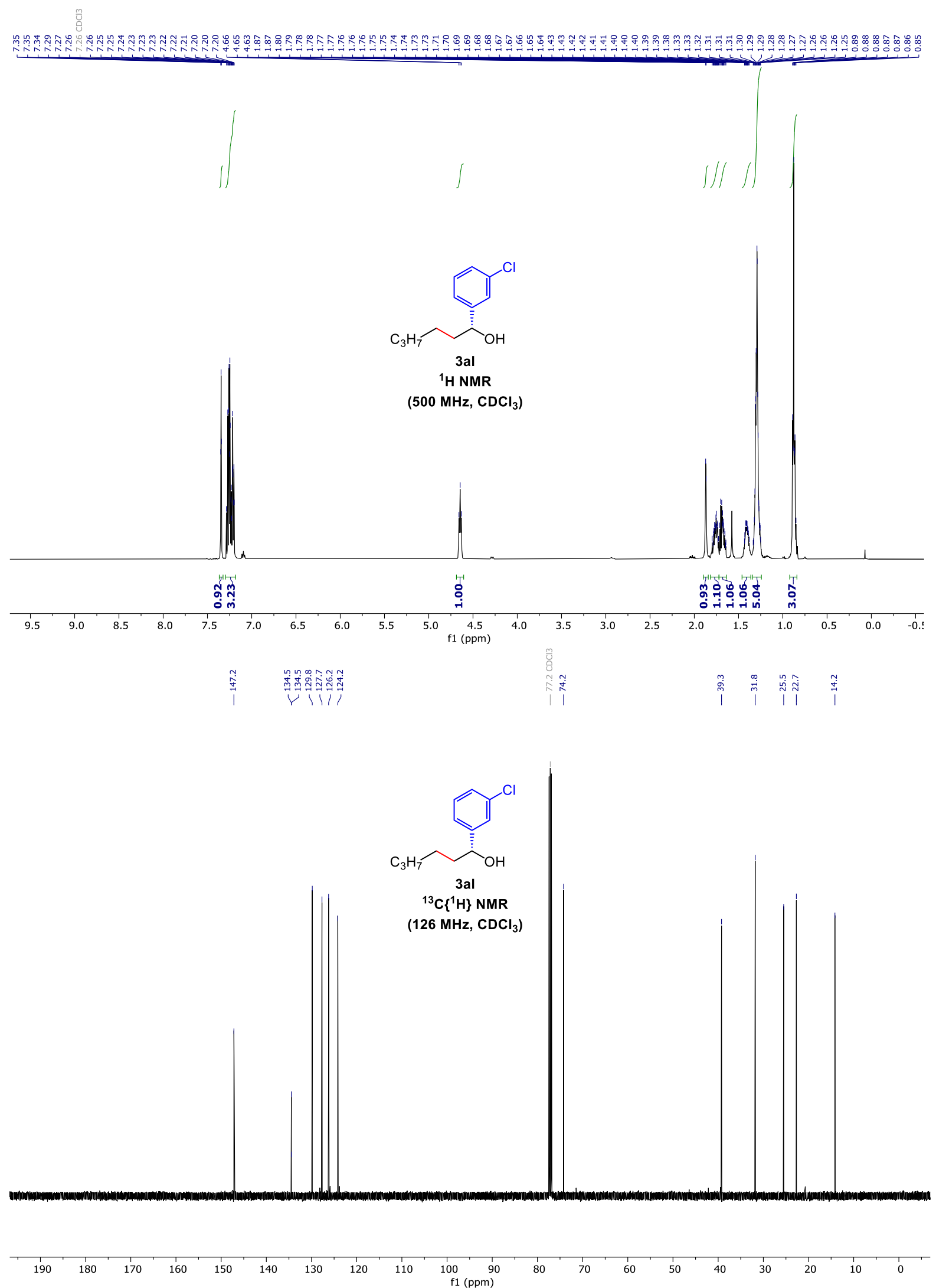

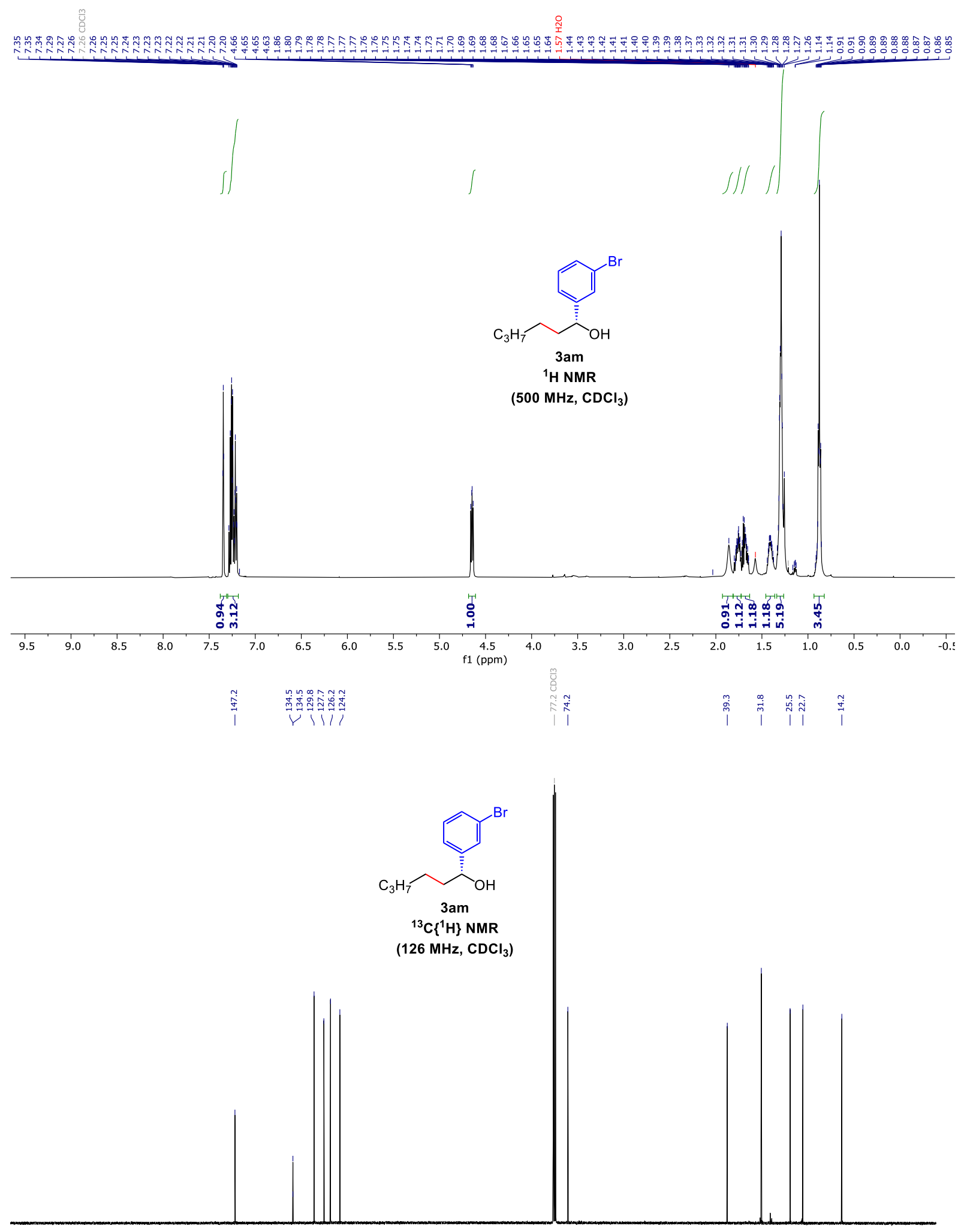

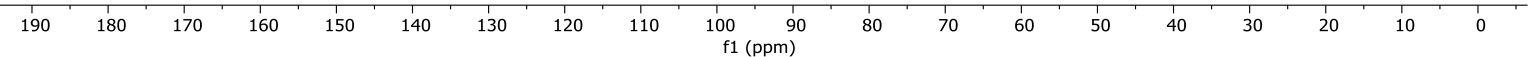



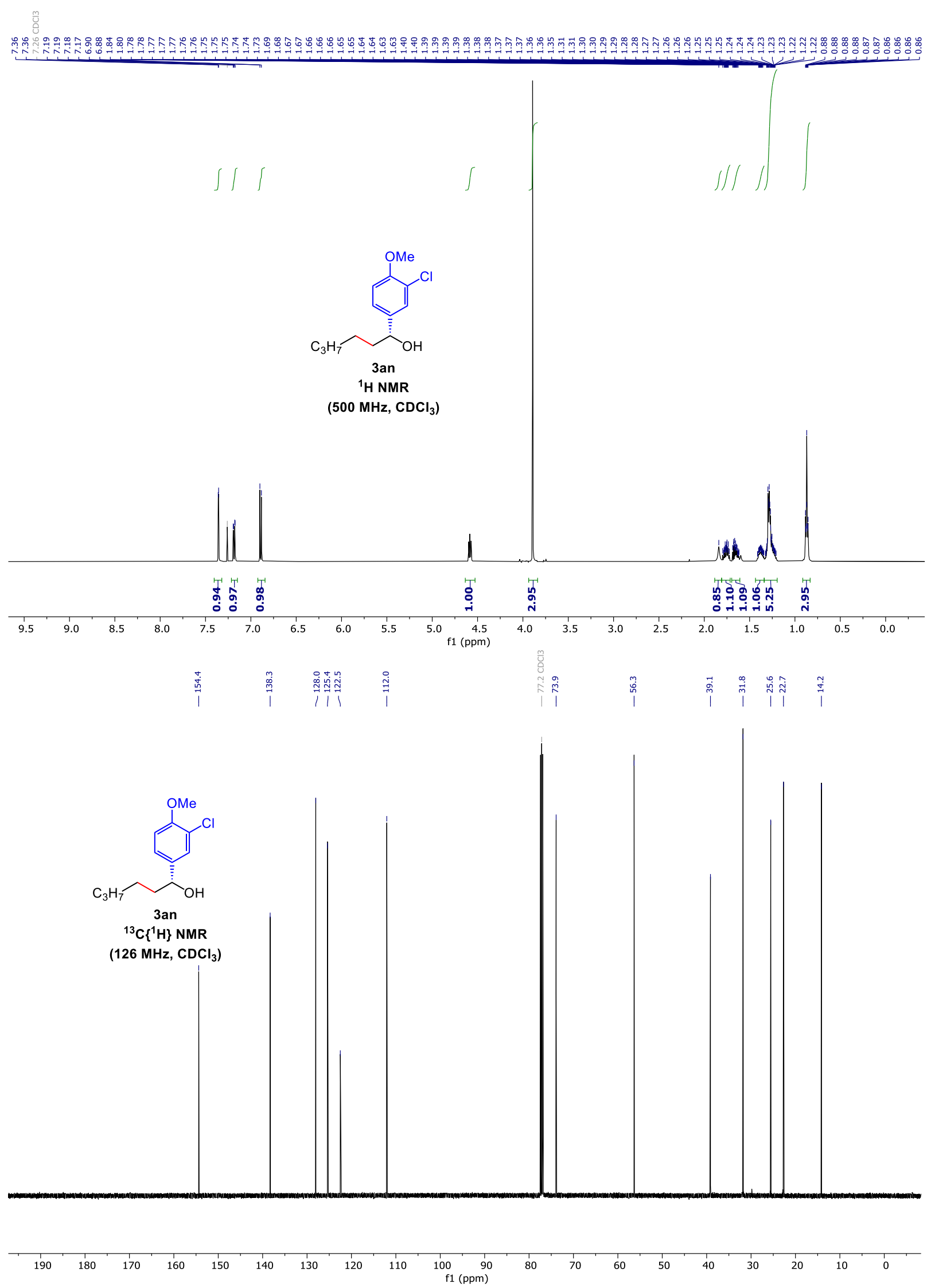


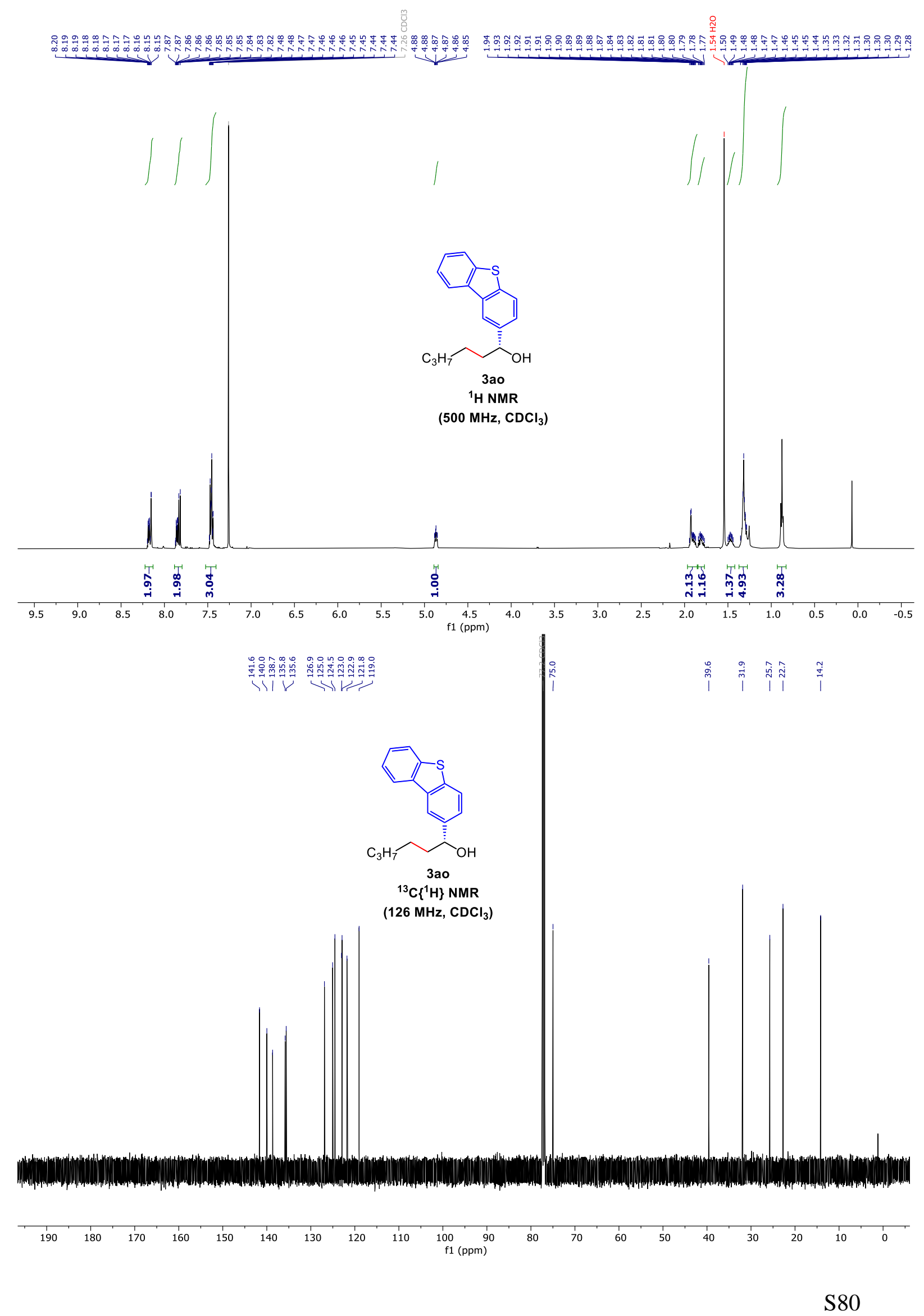




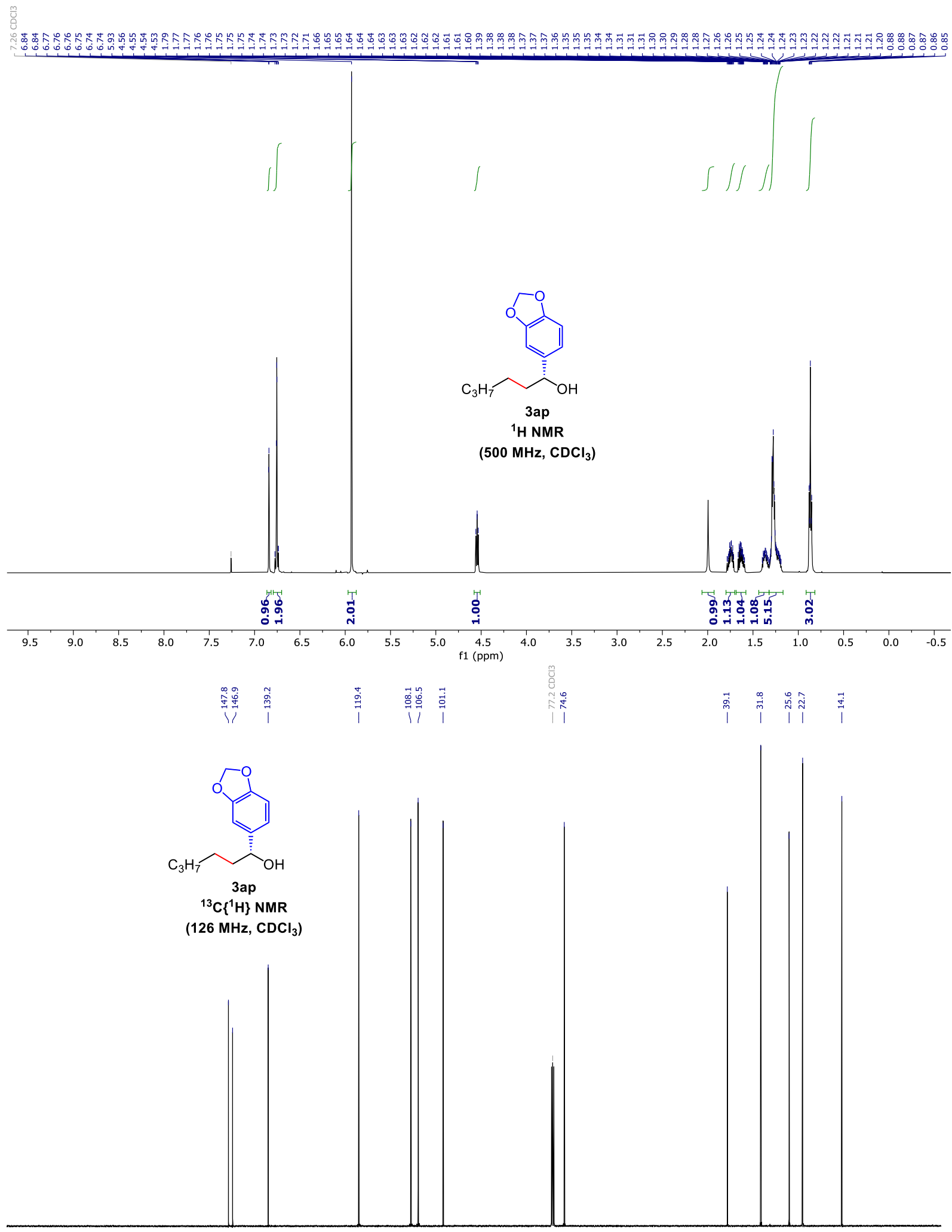

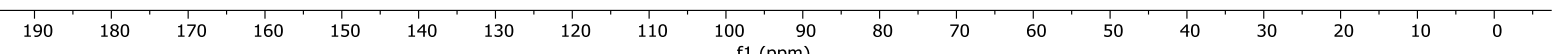




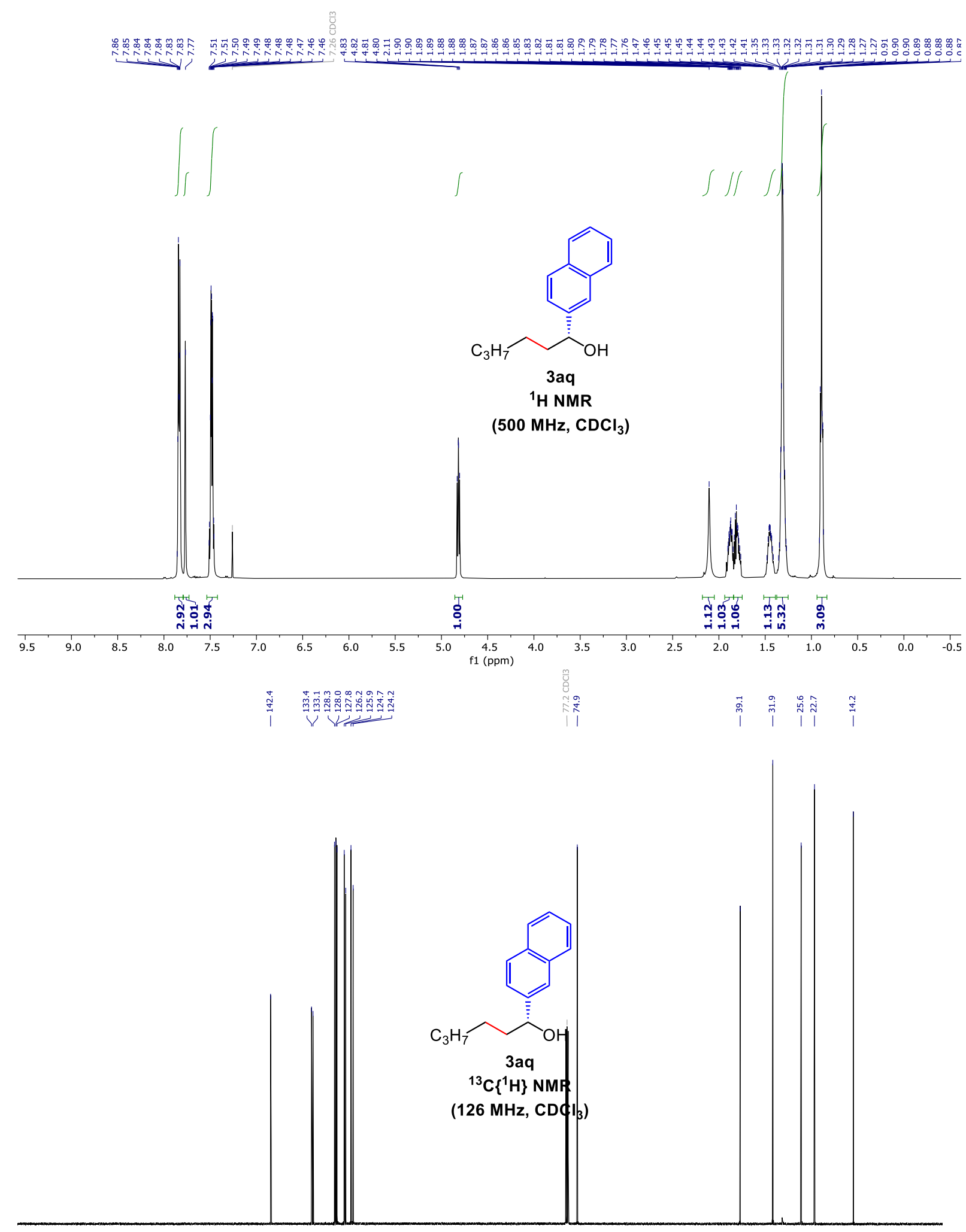

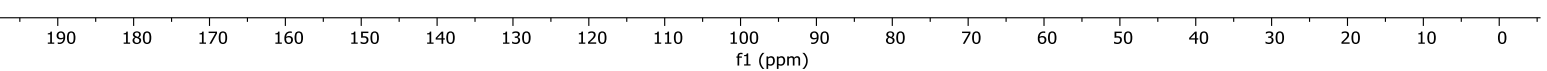




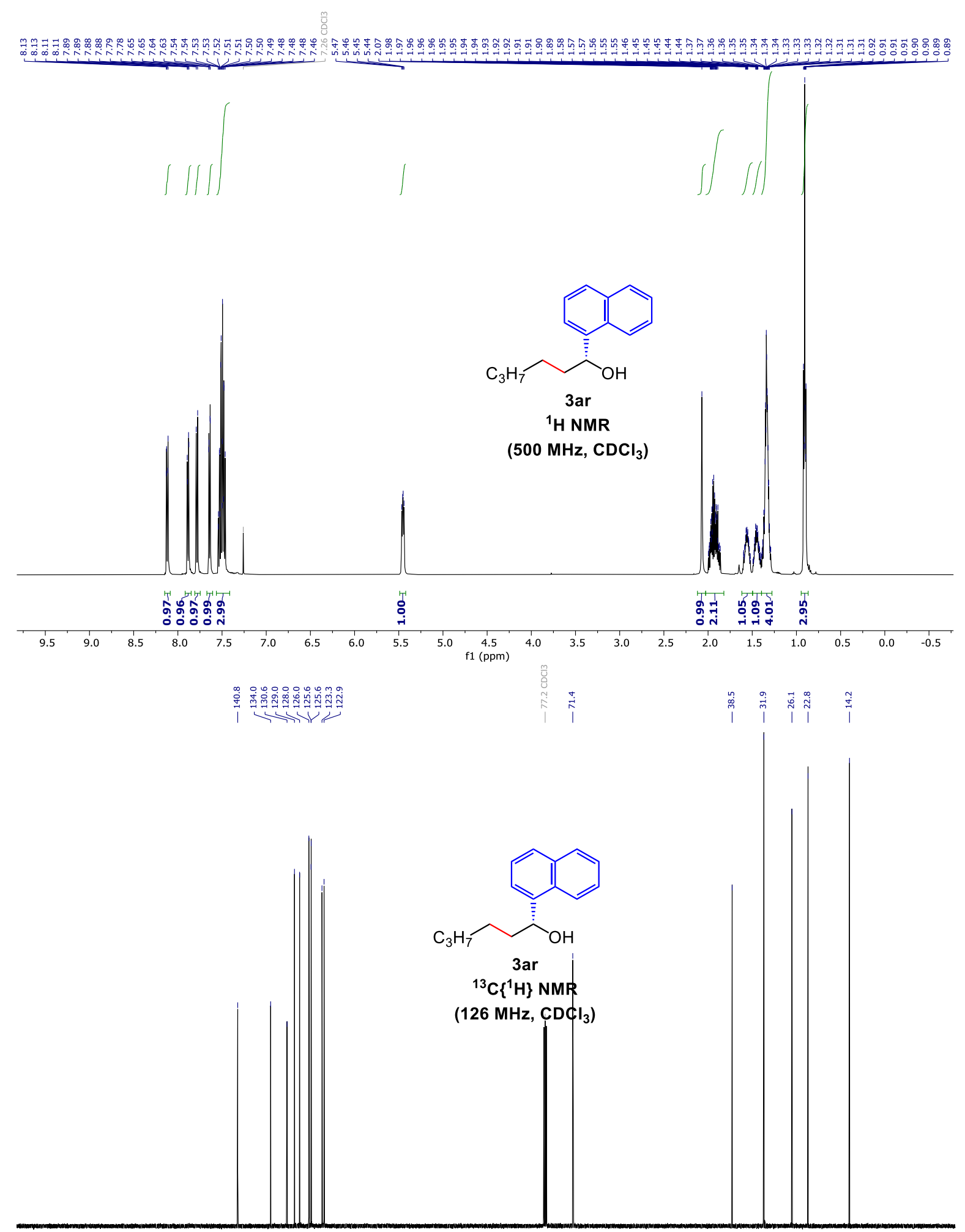

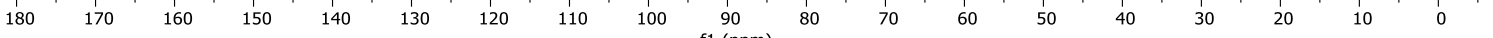




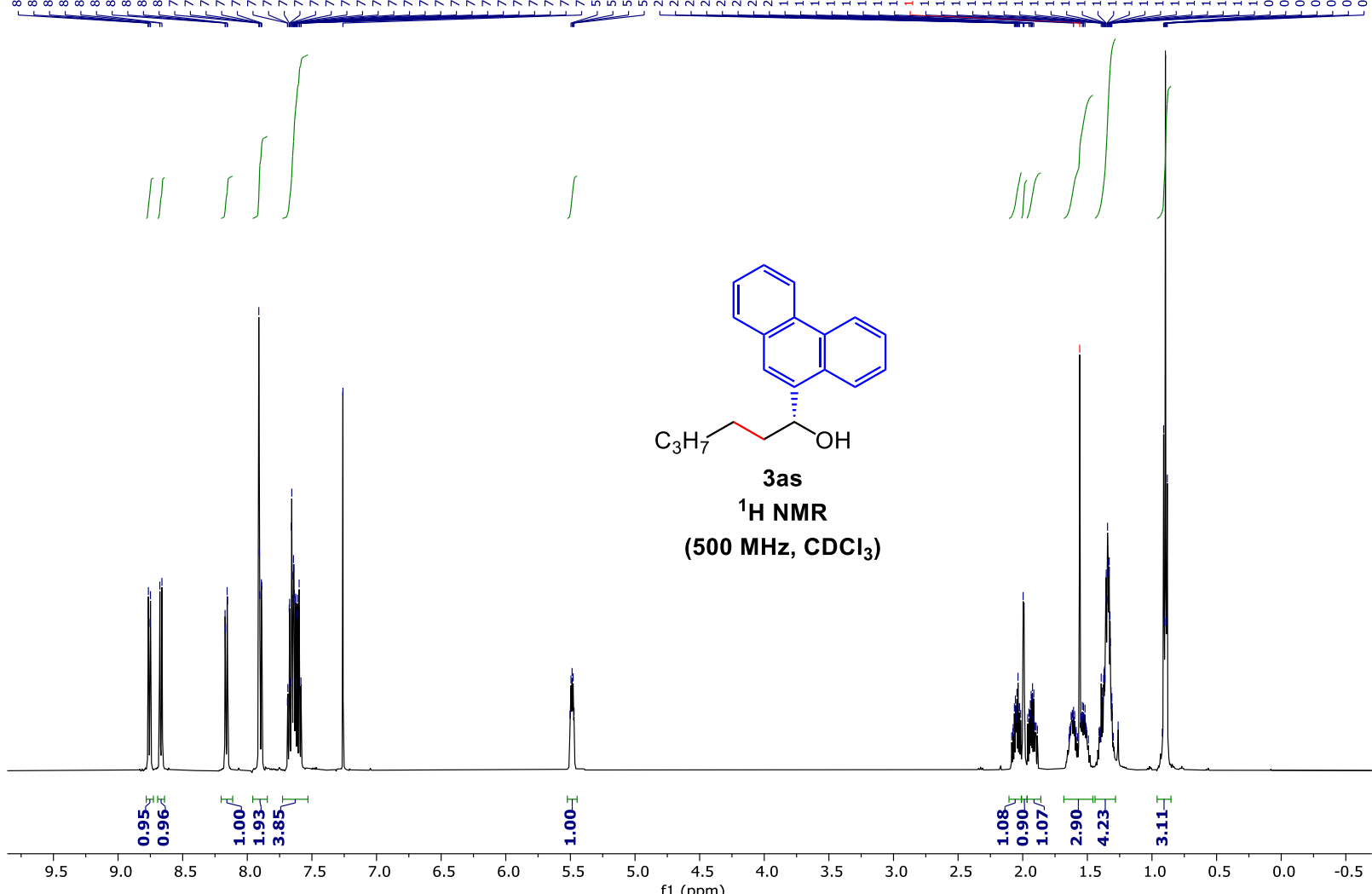

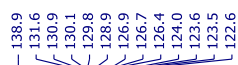

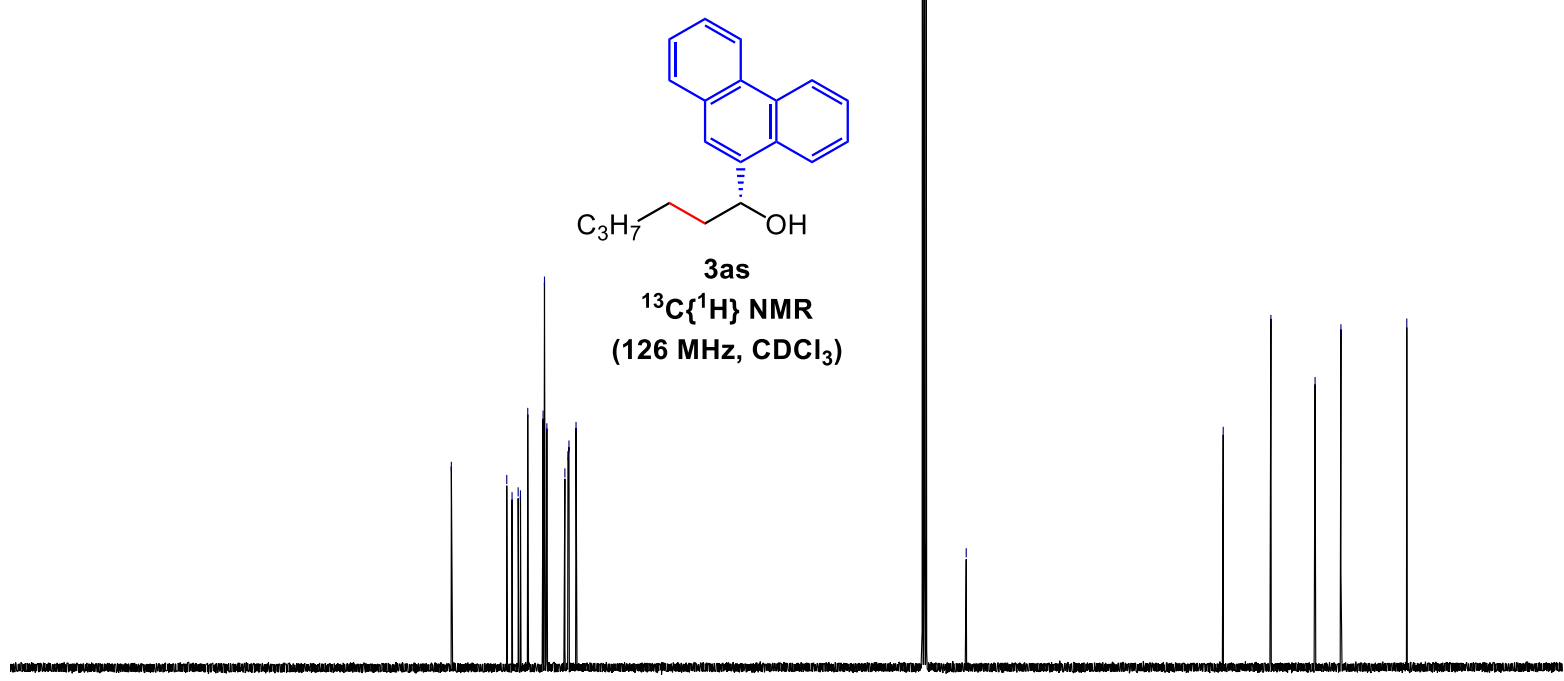


1<smiles>CC(C)(C)CCC[C@H](O)c1ccccc1</smiles>

6aa

${ }^{1} \mathrm{H}$ NMR

$\left(500 \mathrm{MHz}, \mathrm{CDCl}_{3}\right)$
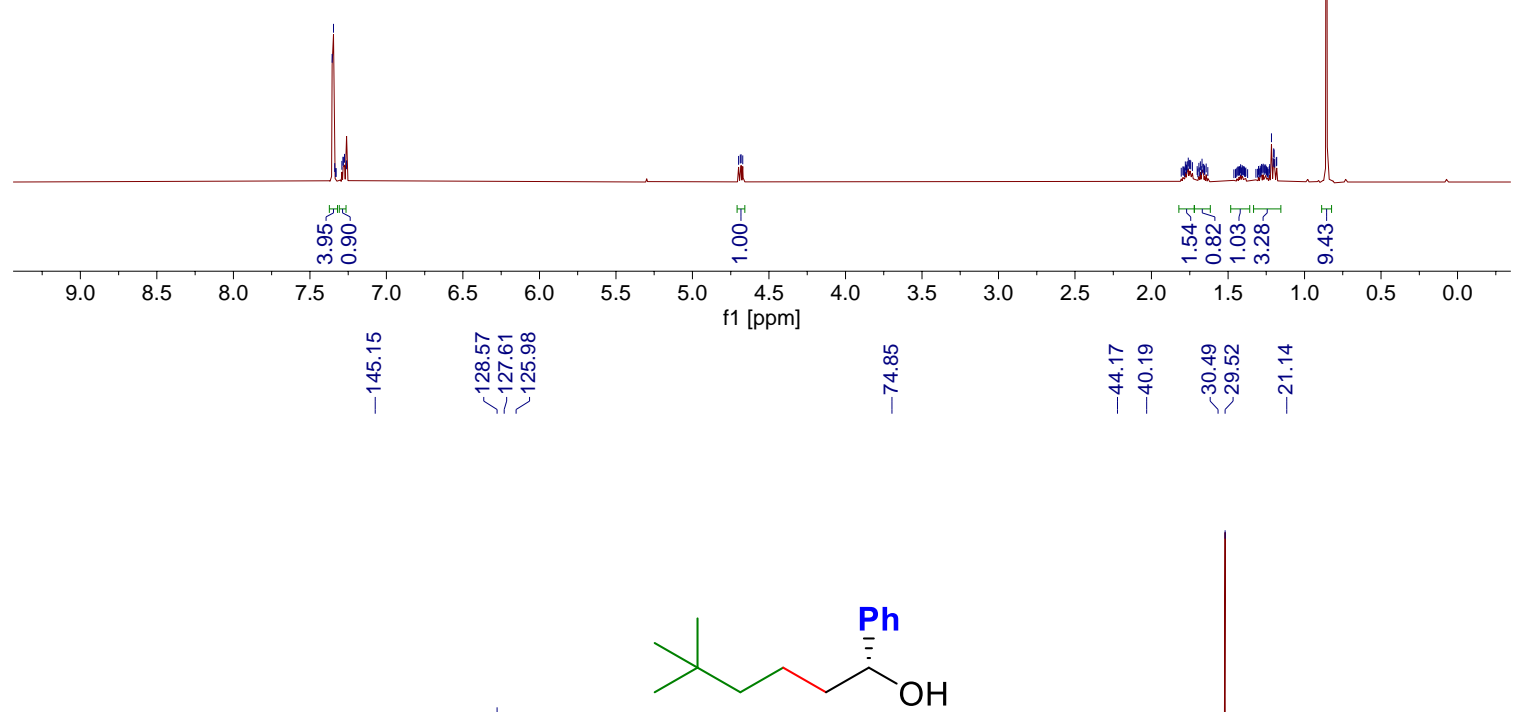

6aa

${ }^{13} \mathrm{C}\left\{{ }^{1} \mathrm{H}\right\}$ NMR

(126 $\mathrm{MHz}, \mathrm{CDCl}_{3}$ )

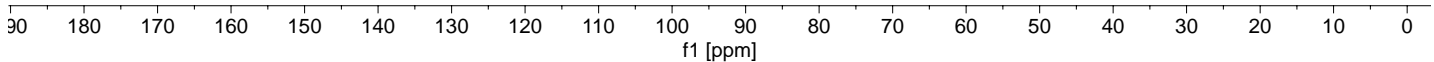




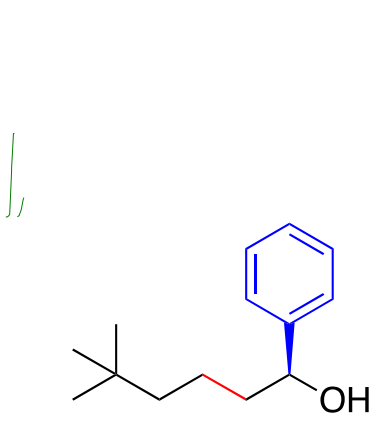

6aa - prepared on a

2.44 mmol reaction

scale

${ }^{1} \mathrm{H}$ NMR

$\left(500 \mathrm{MHz} \mathrm{CDCl}_{3}\right)$

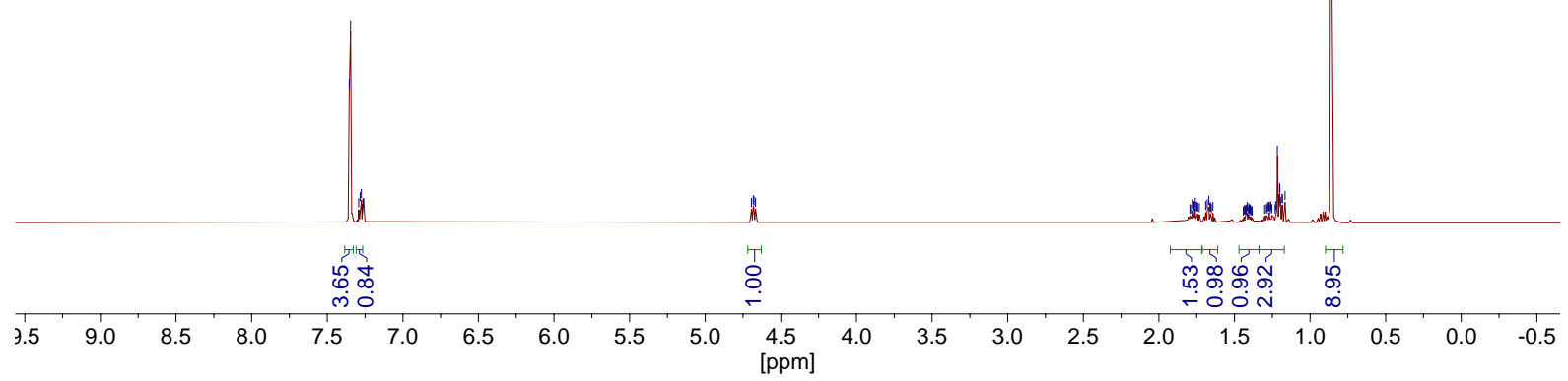

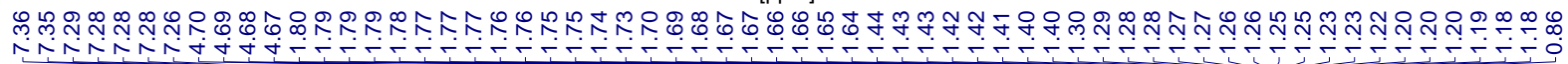

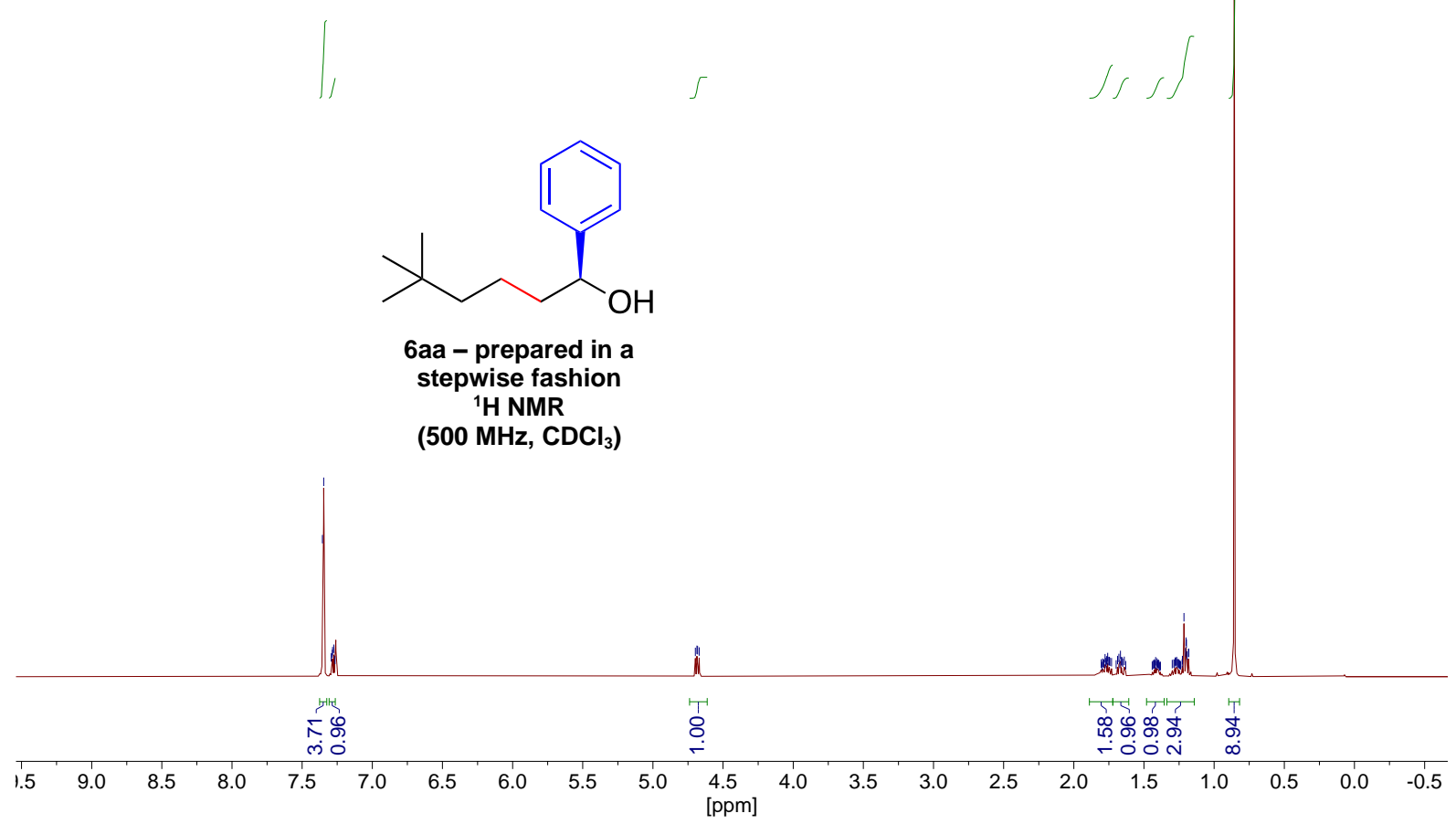




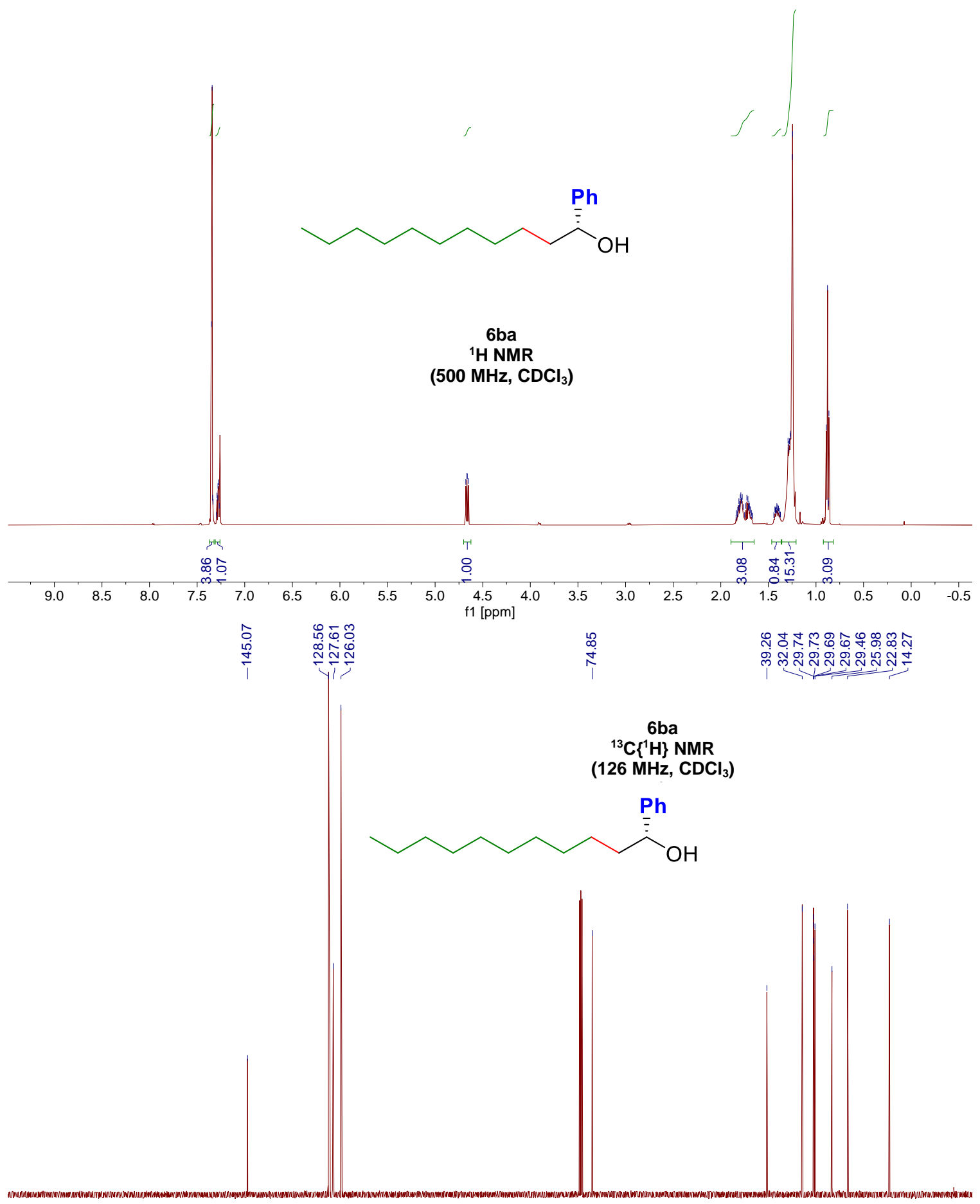

\begin{tabular}{llll}
\hline 190 & 180 & 170 & 160
\end{tabular}

$150 \quad 140$

130

110

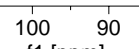

f1 [ppm] 


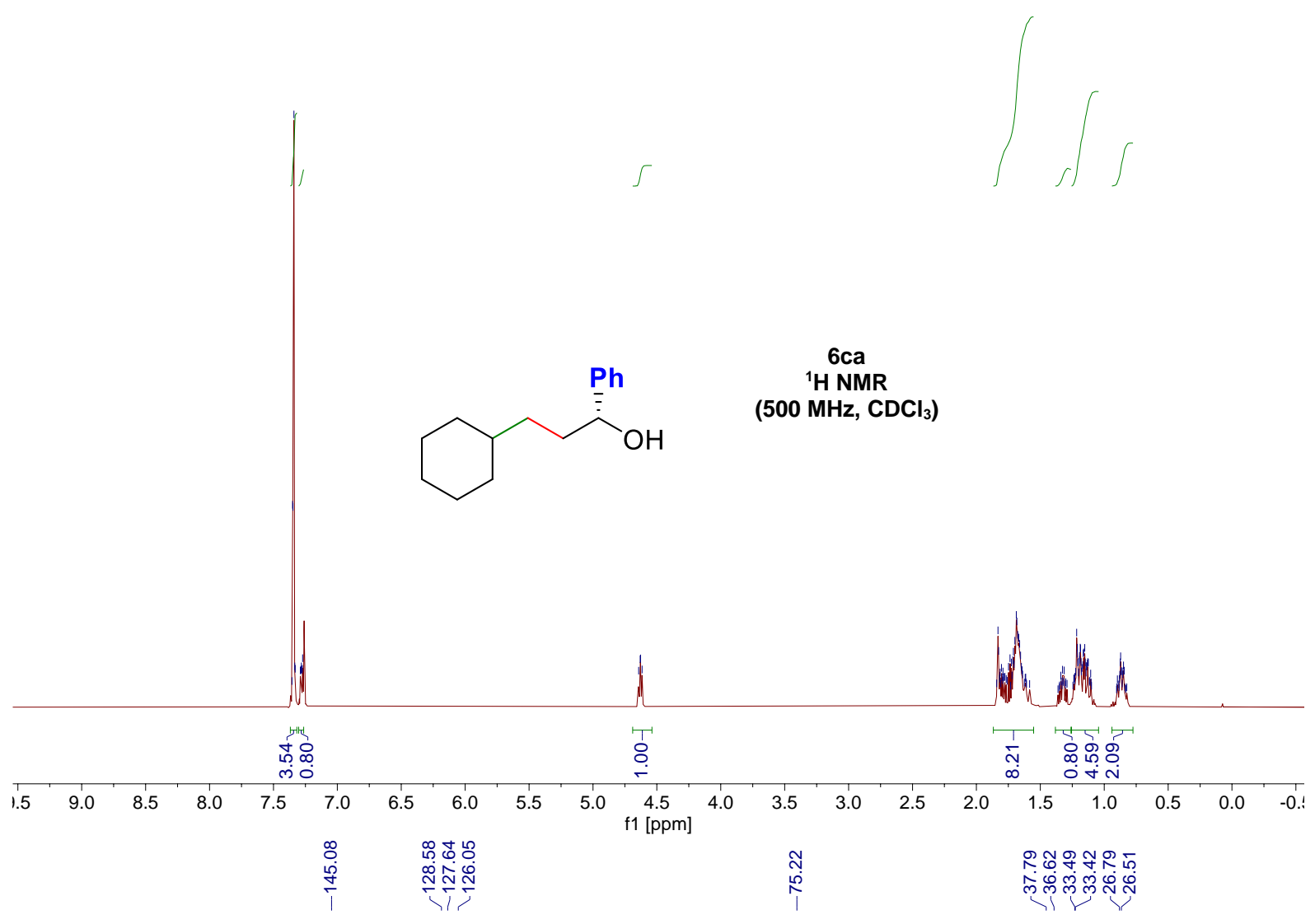<smiles>OC(CCC1CCCCC1)c1ccccc1</smiles>

$6 \mathrm{ca}$

${ }^{13} \mathrm{C}\left\{{ }^{1} \mathrm{H}\right\}$ NMR

(126 MHz, $\mathrm{CDCl}_{3}$ )

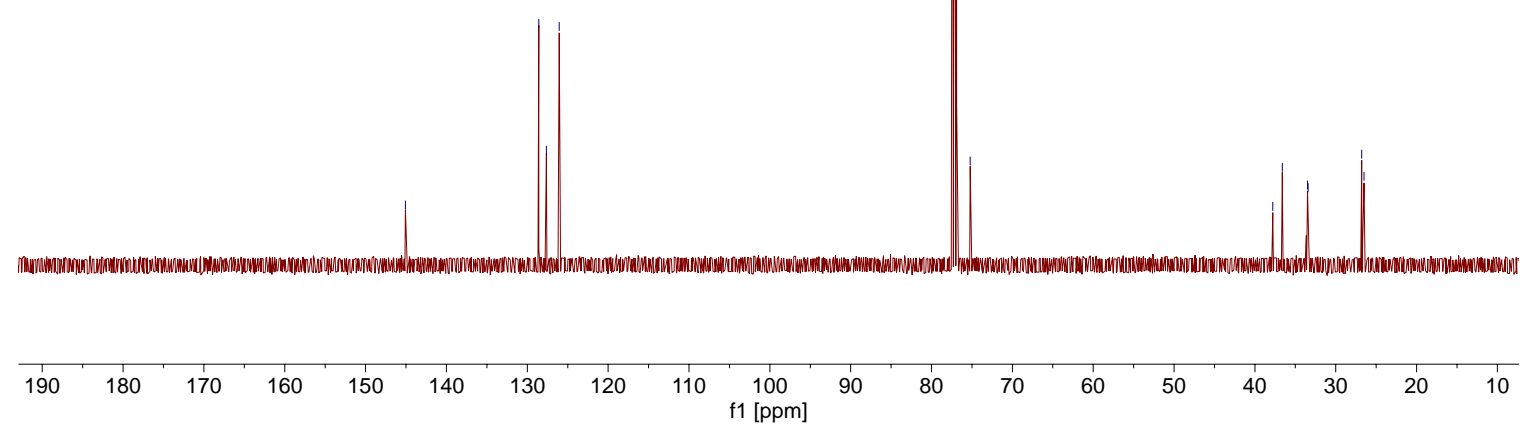




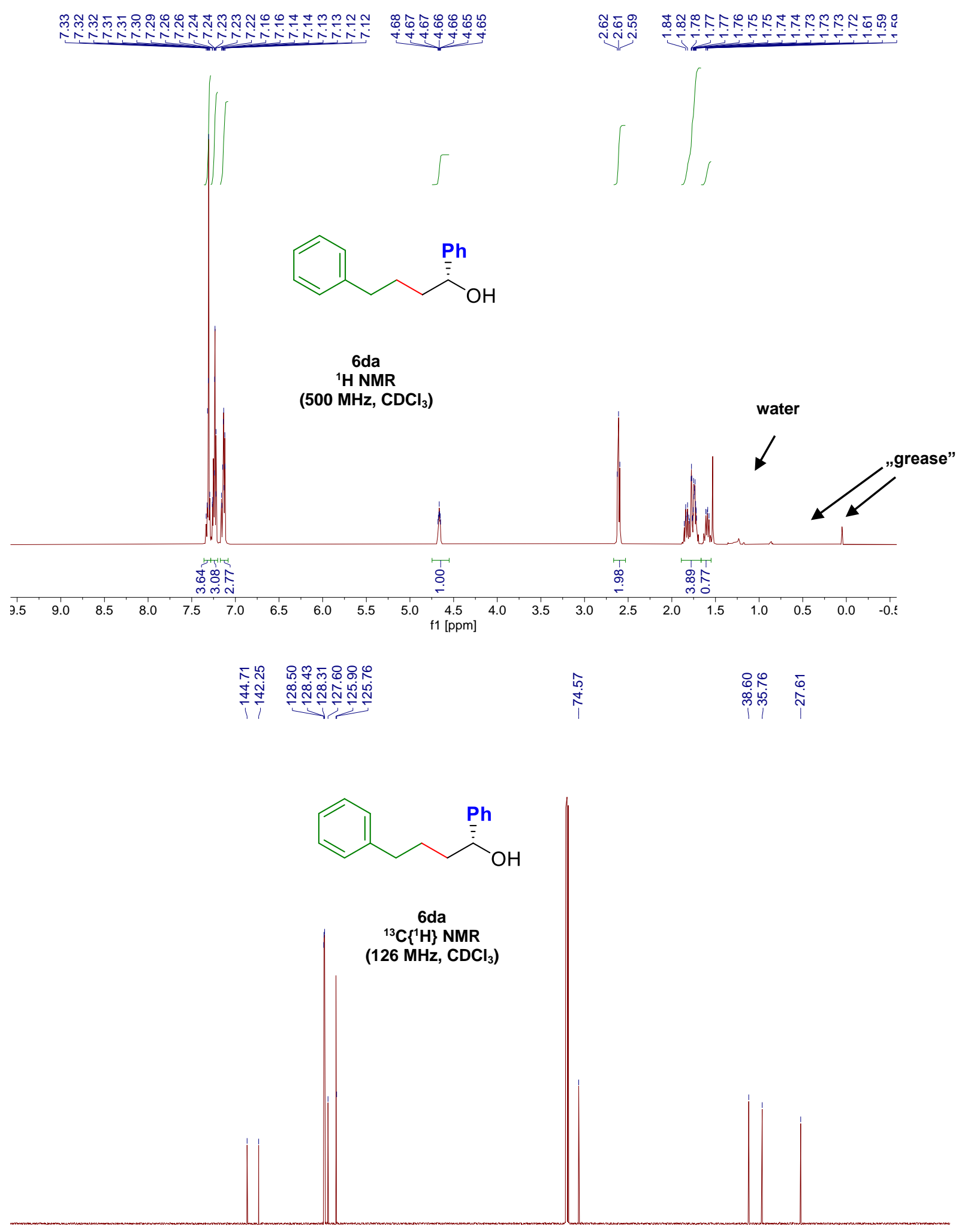

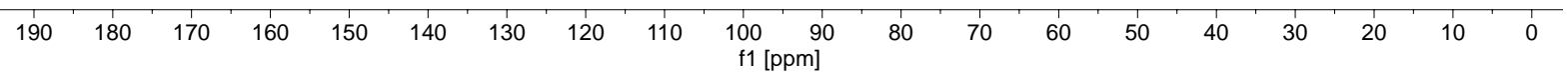



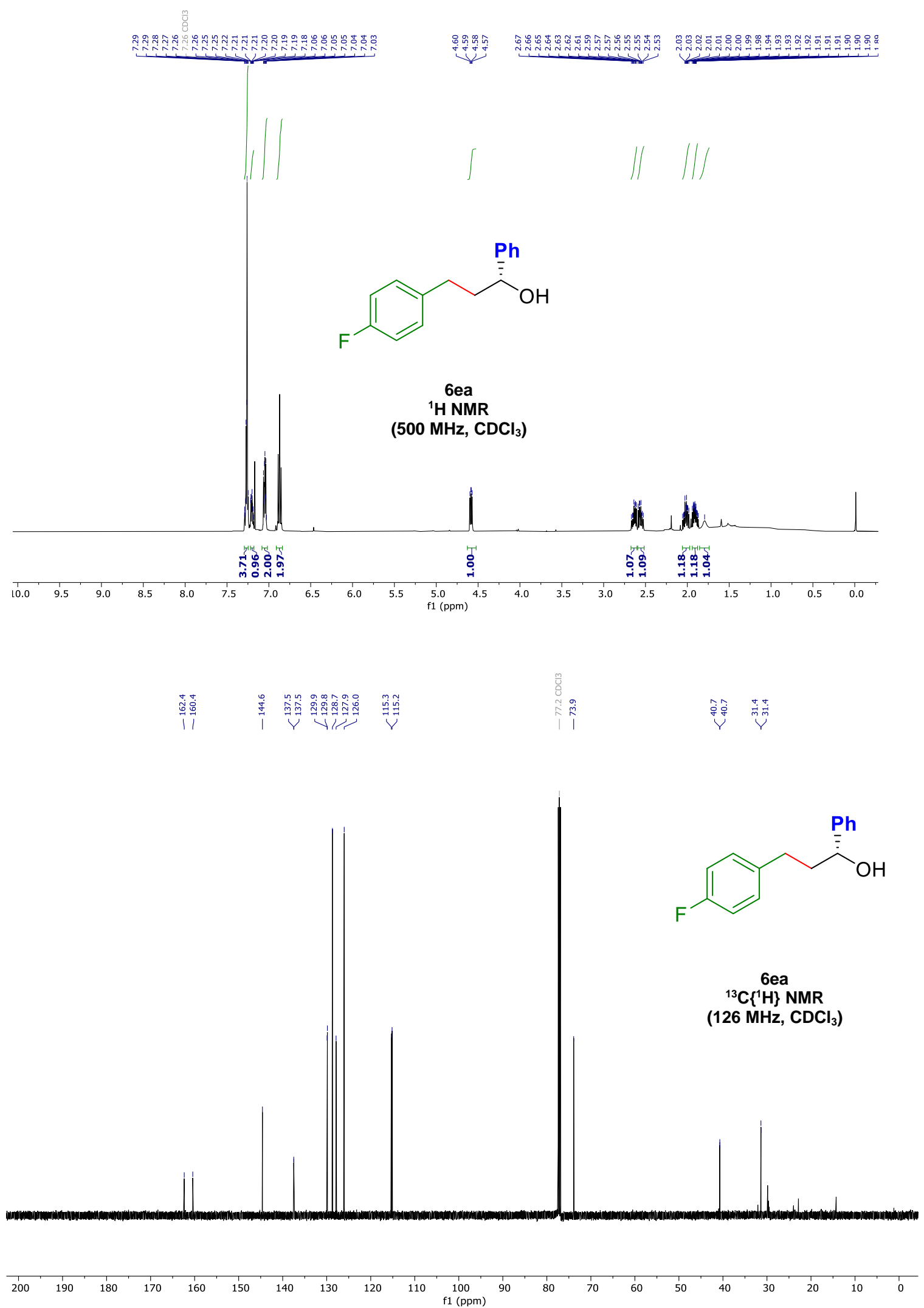


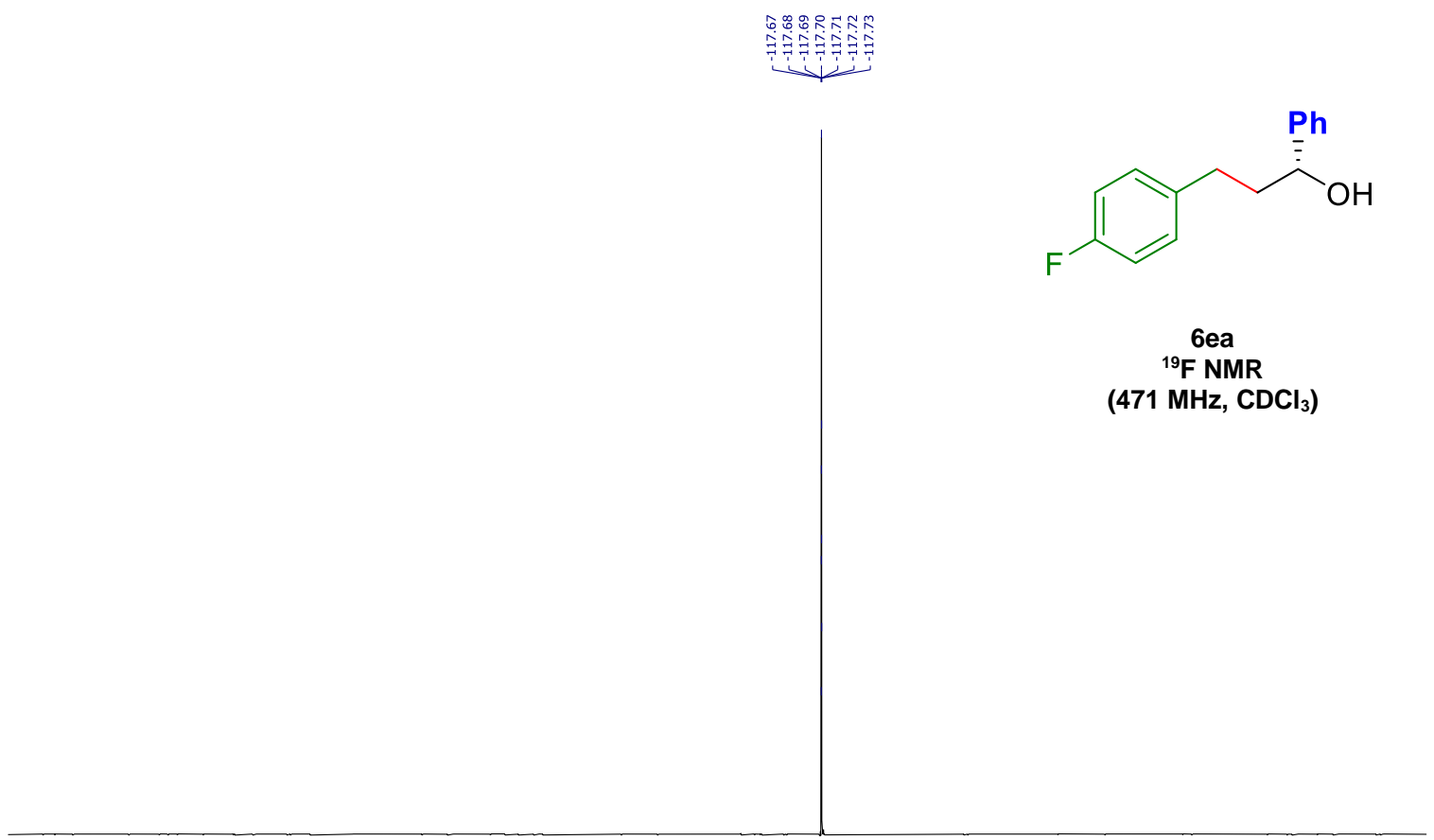

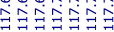

\begin{tabular}{|llllllllllllllllllllllllllll}
\hline 20 & 10 & 0 & -10 & -20 & -30 & -40 & -50 & -60 & -70 & -80 & -90 & -100 & -110 & -120 & -130 & -140 & -150 & -160 & -170 & -180 & -190 & -200 & -210 & -2
\end{tabular} 

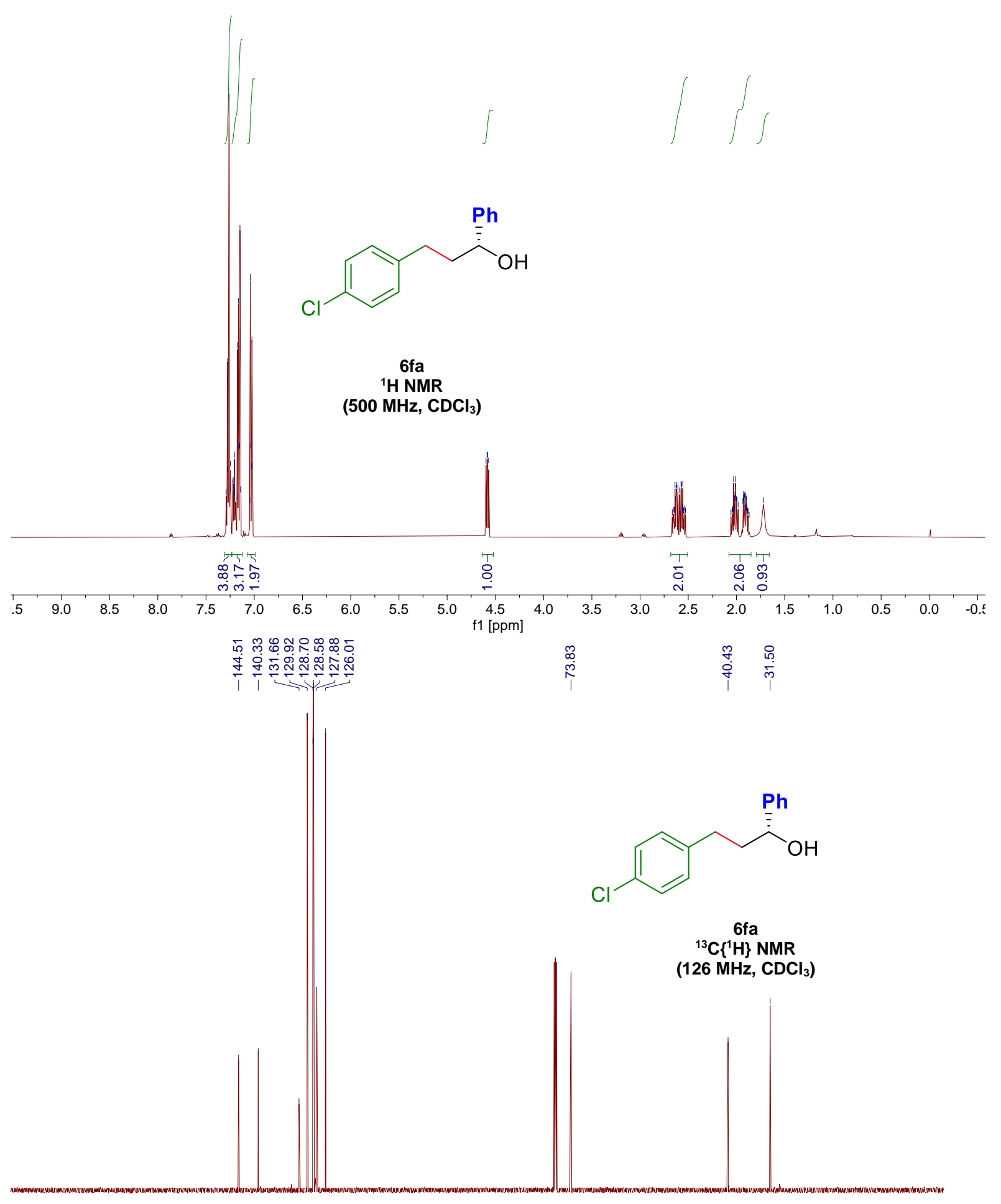

$\begin{array}{llllllllllllllllllll}190 & 180 & 170 & 160 & 150 & 140 & 130 & 120 & 110 & \begin{array}{r}100 \\ \mathrm{f} 1\end{array}\left[\begin{array}{l}1 \\ {[\mathrm{ppm}]}\end{array}\right. & 80 & 70 & 60 & 50 & 40 & 30 & 20 & 10 & 0\end{array}$ 


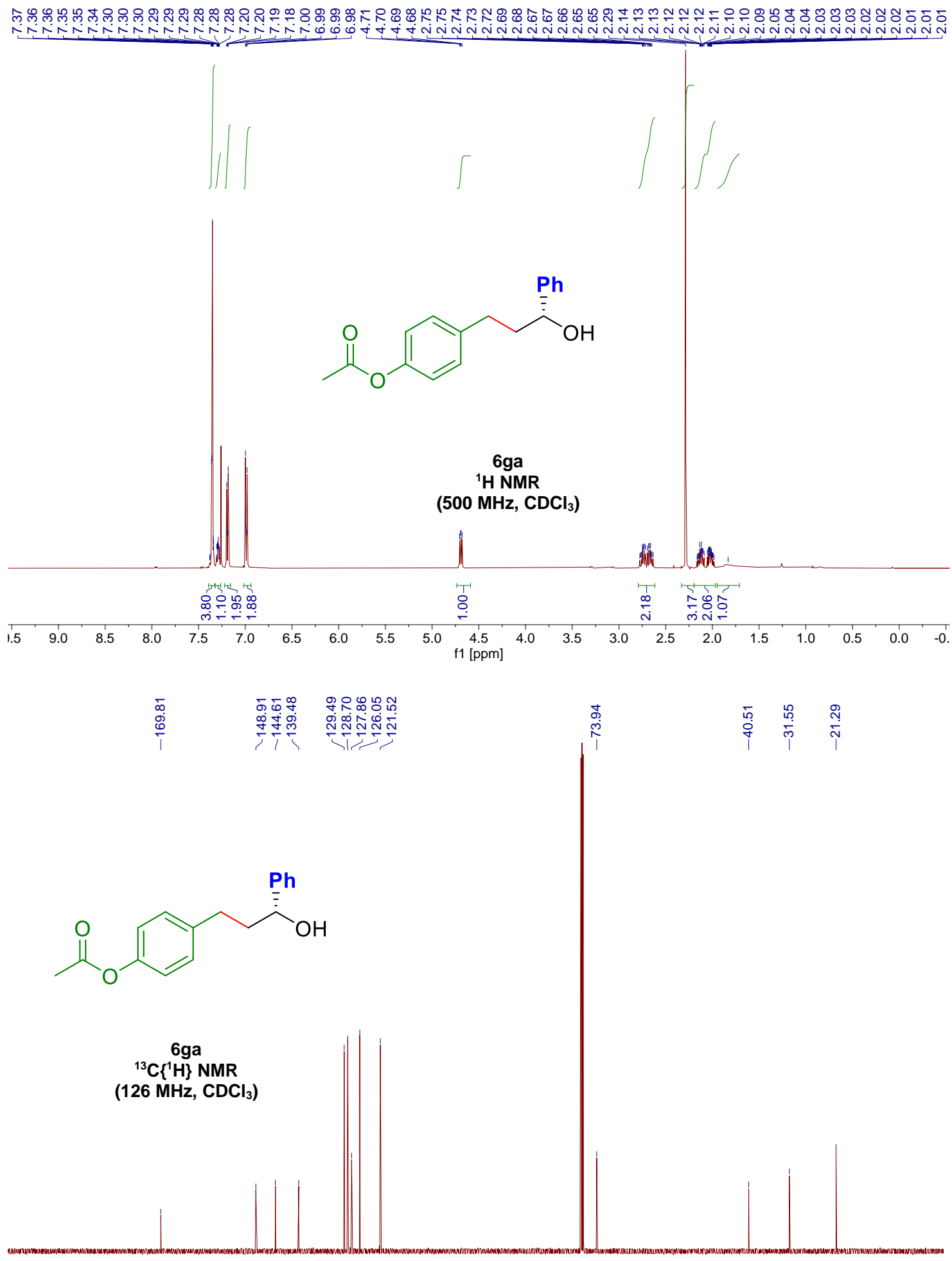

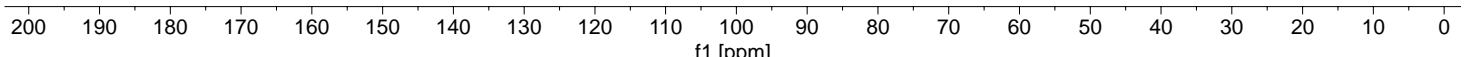



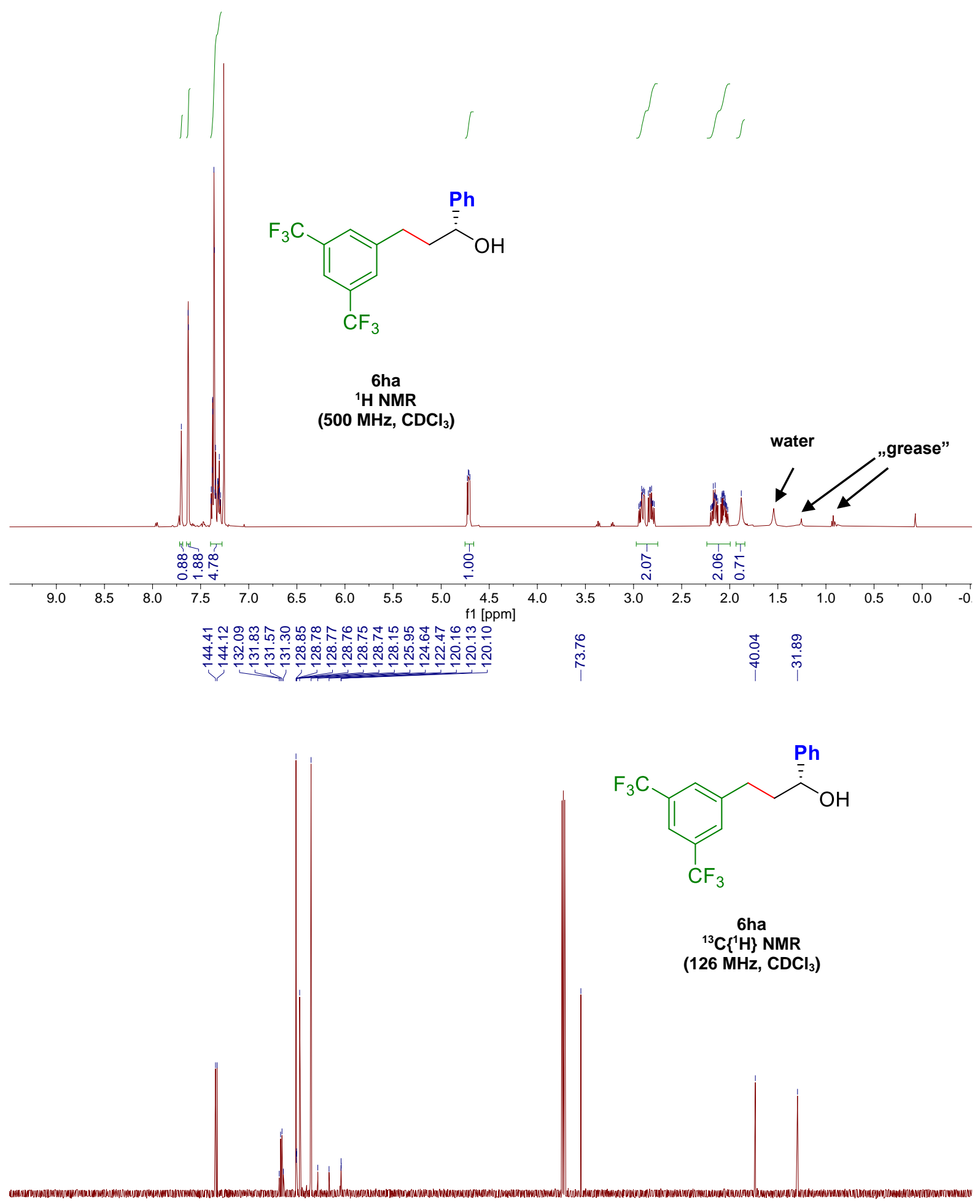

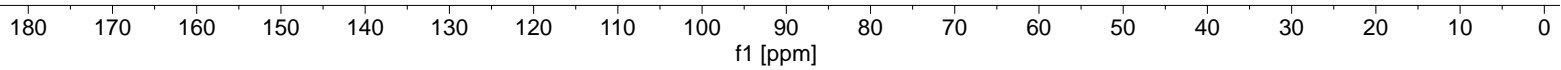




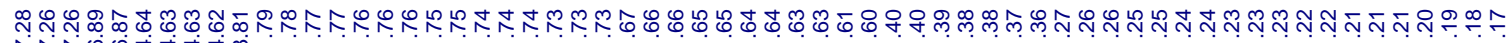
ヘ

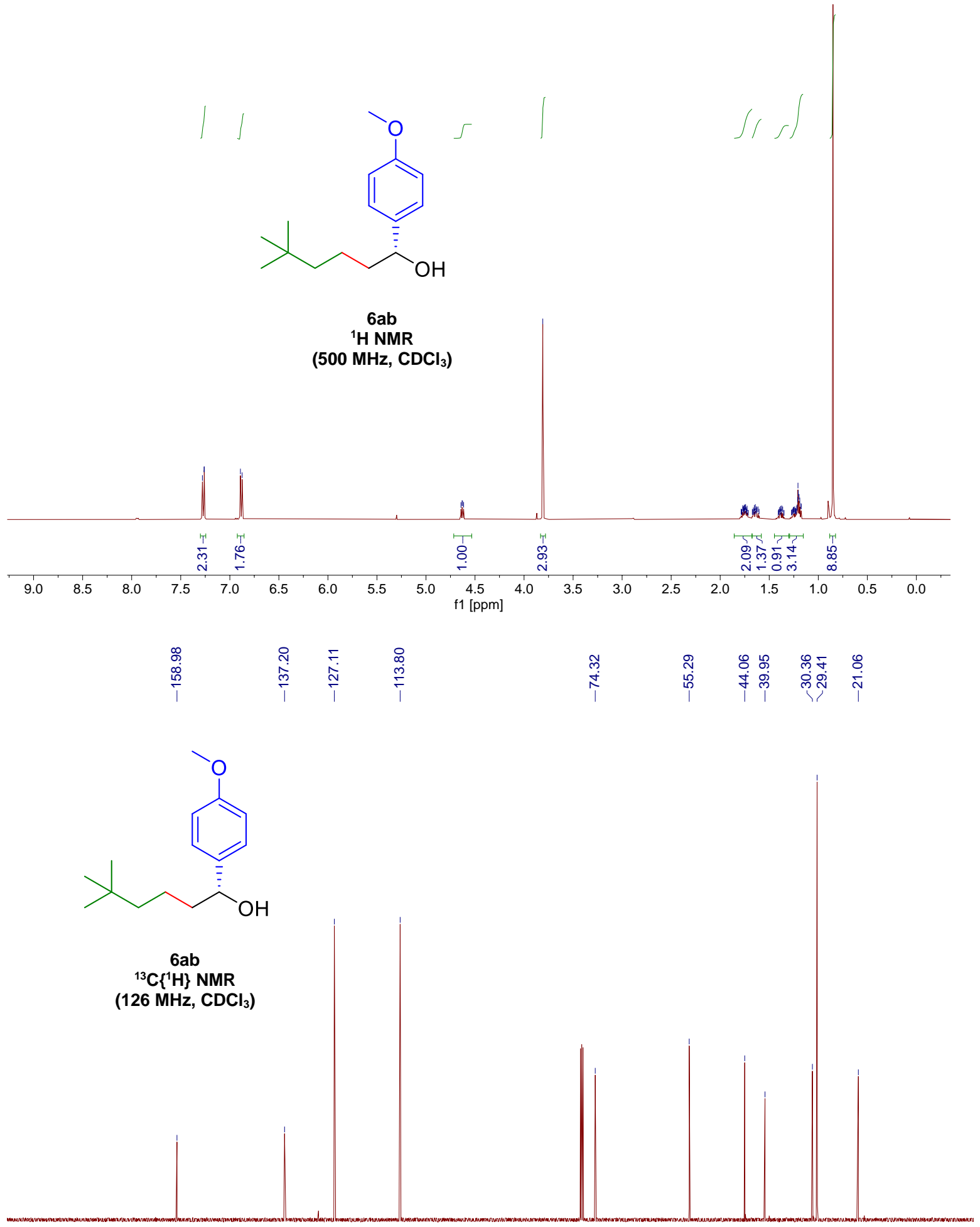

$\begin{array}{llllllllllllllllllll}190 & 180 & 170 & 160 & 150 & 140 & 130 & 120 & 110 & \begin{array}{c}100 \\ \mathrm{f} 1\end{array}\left[\begin{array}{c}1 \mathrm{ppm}] \\ 1\end{array}\right. & 80 & 70 & 60 & 50 & 40 & 30 & 20 & 10 & 0\end{array}$ 


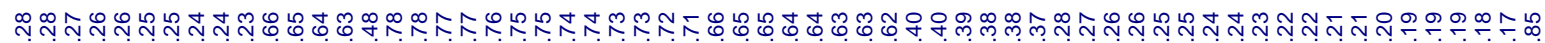

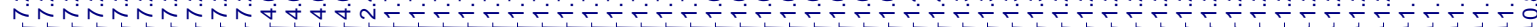

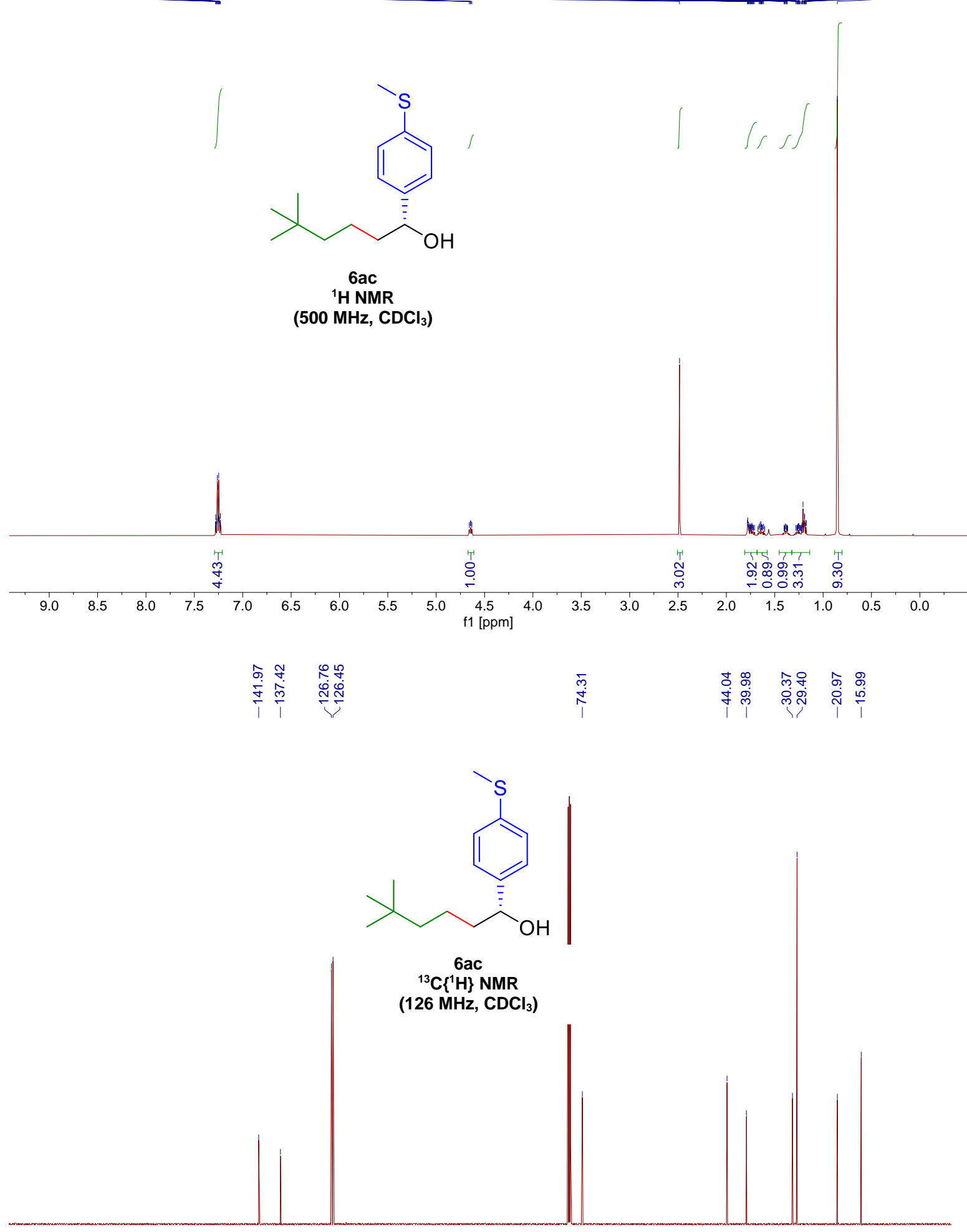

$\begin{array}{llllllllllllllllllll}190 & 180 & 170 & 160 & 150 & 140 & 130 & 120 & 110 & \begin{array}{c}100 \\ \mathrm{f} 1[\mathrm{ppm}]\end{array} & 80 & 70 & 60 & 50 & 40 & 30 & 20 & 10 & 0\end{array}$ 

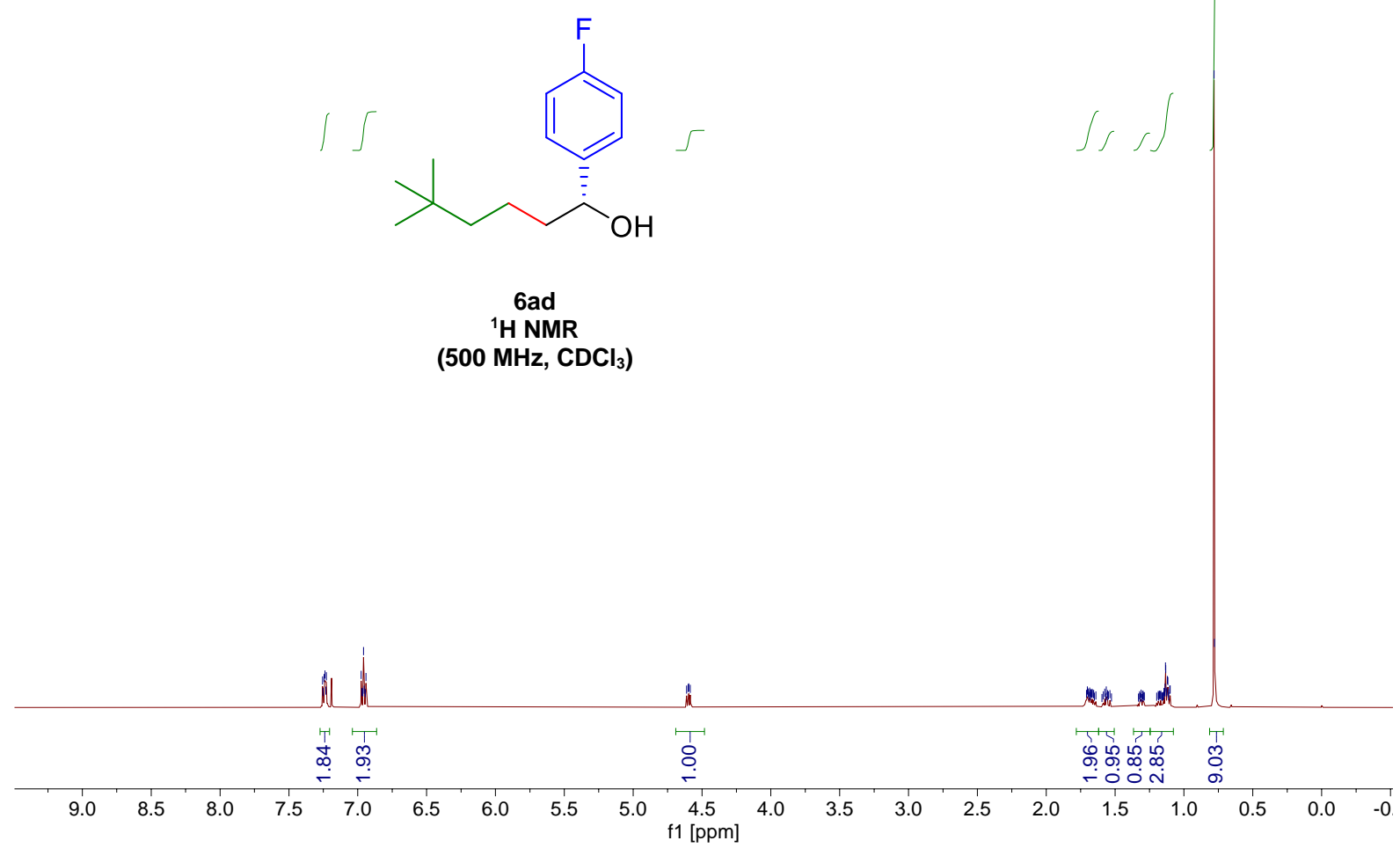

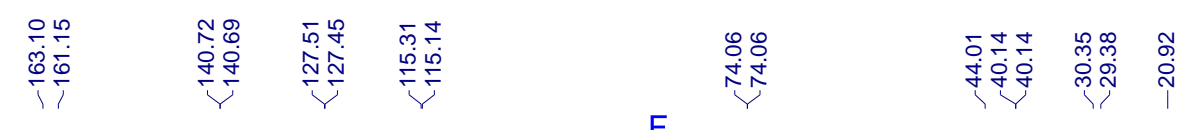
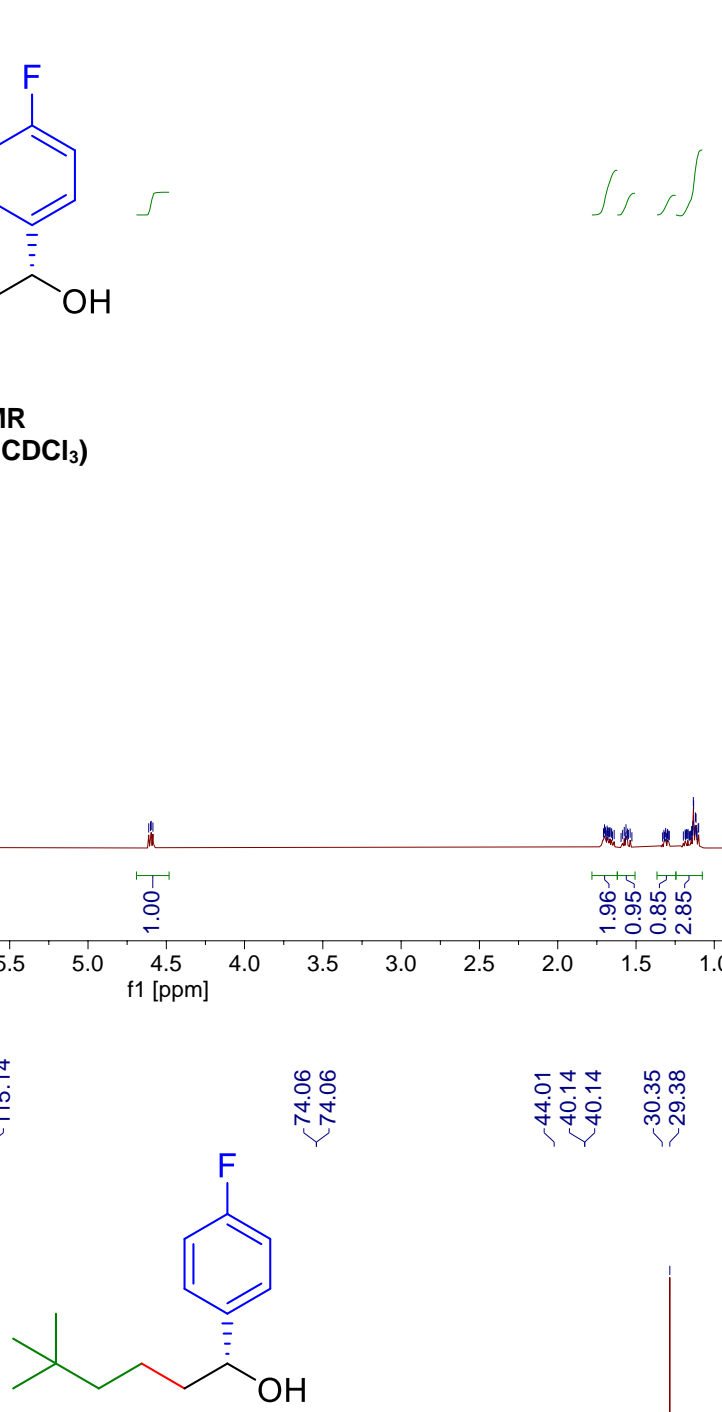


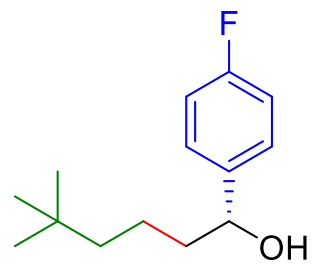

$\infty$ 웅

i

6ad

${ }^{19} \mathrm{~F}$ NMR

(476 MHz, $\mathrm{CDCl}_{3}$ )

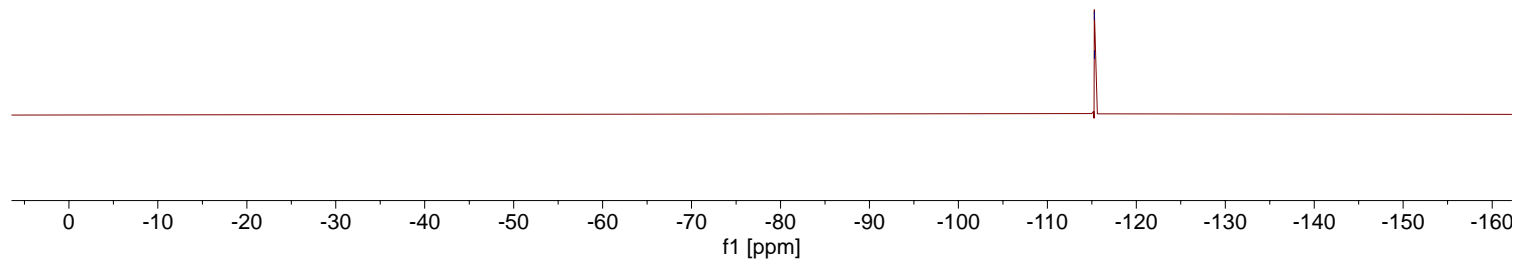




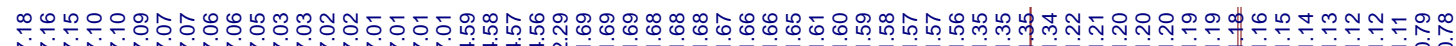

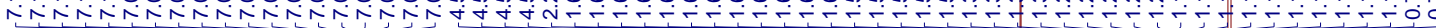<smiles>Cc1cccc(C(O)CCCC(C)(C)C)c1</smiles>
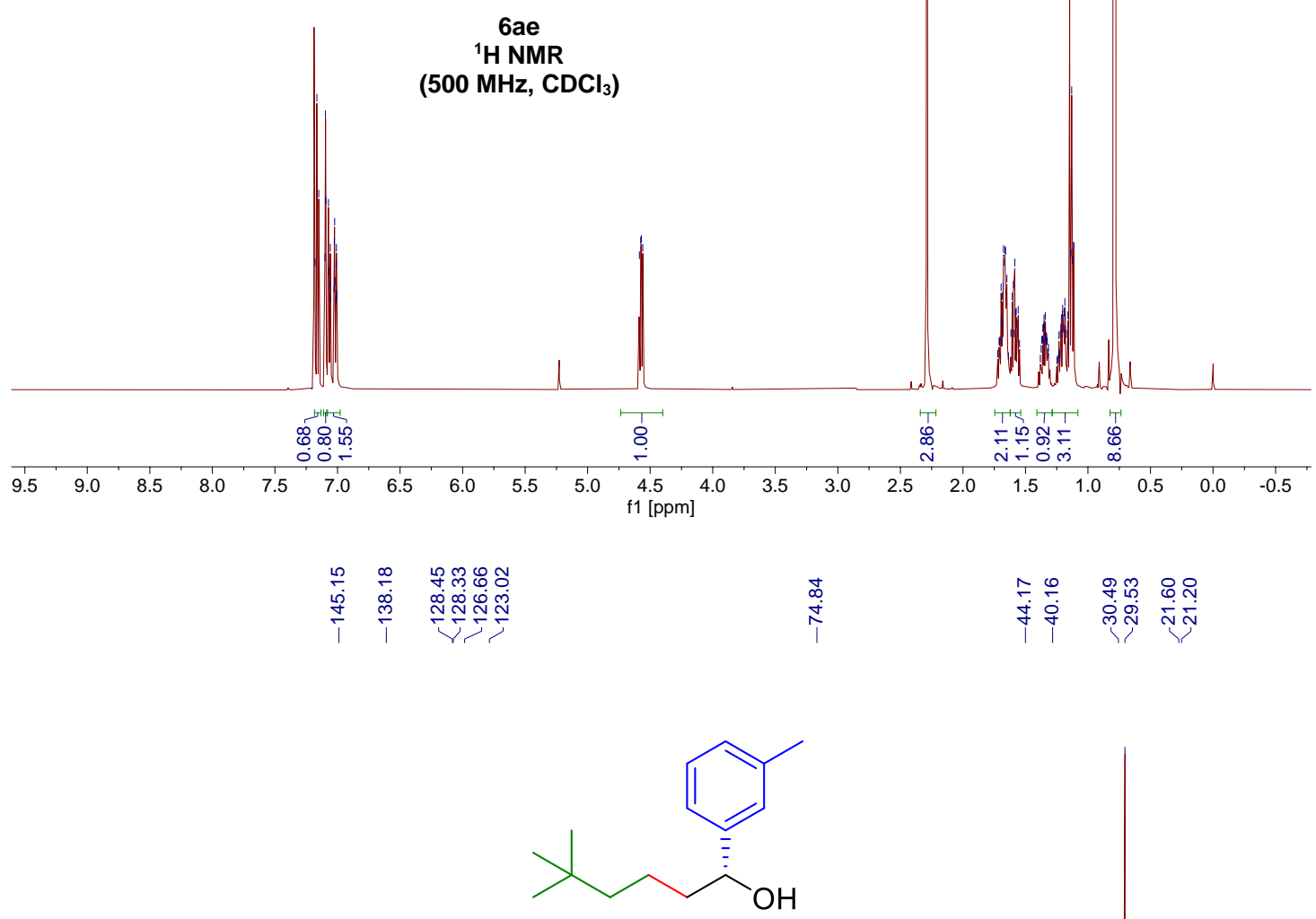

6ae

${ }^{13} \mathrm{C}\left\{{ }^{1} \mathrm{H}\right\}$ NMR

(126 MHz, $\mathrm{CDCl}_{3}$ )

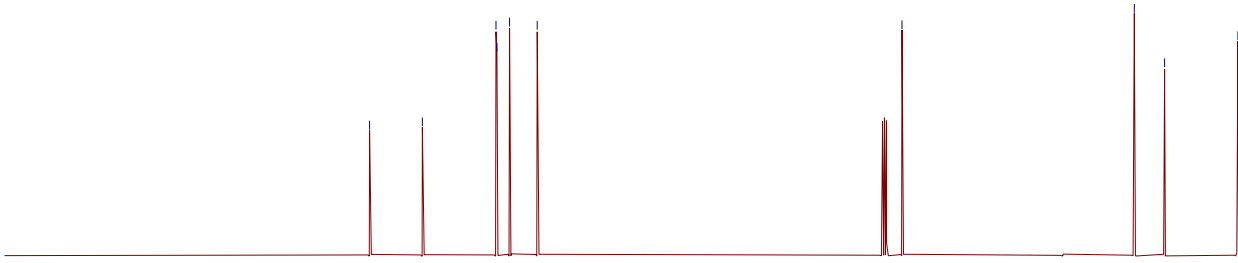

190

f1 100 ppm] 

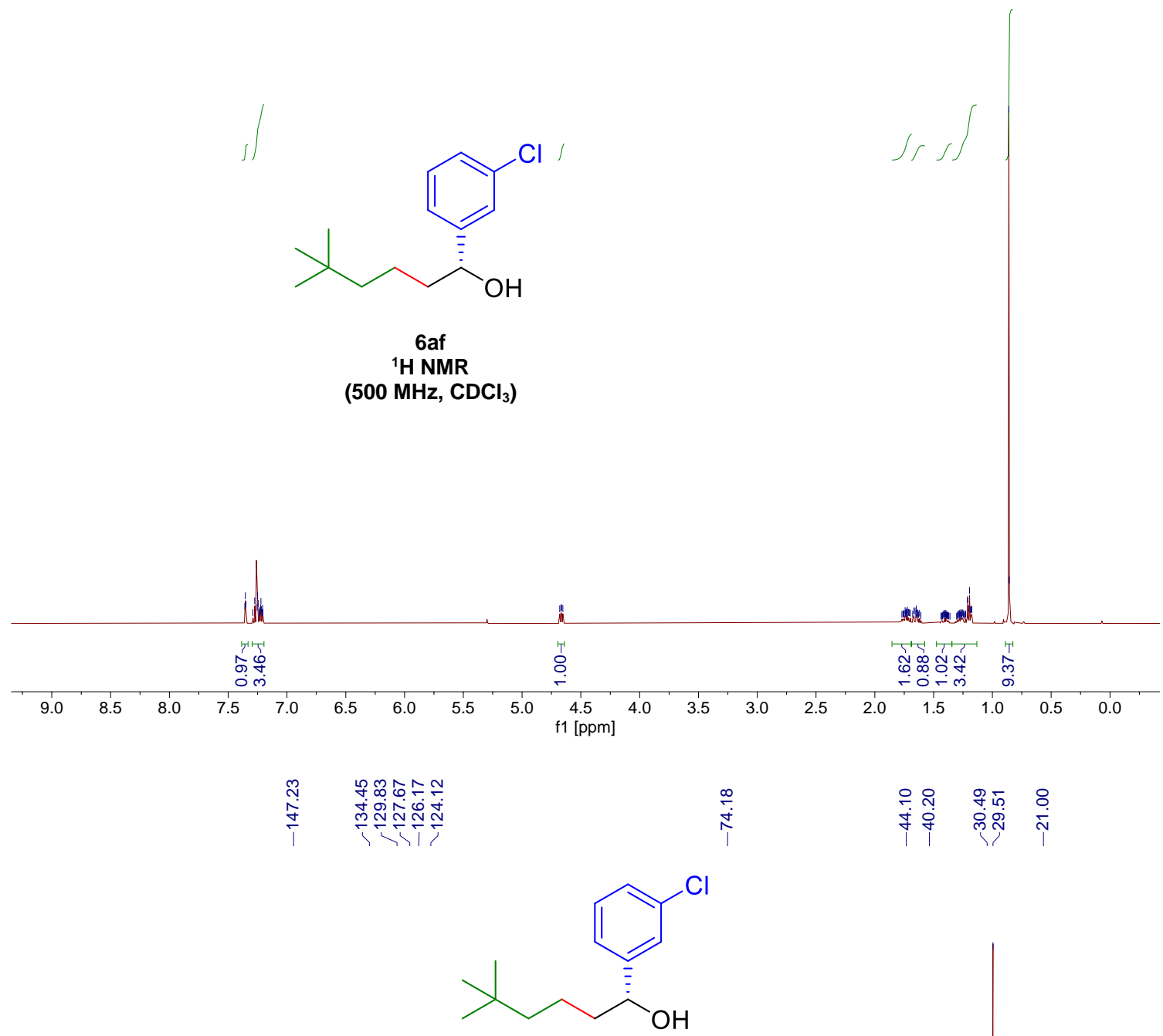

6af

${ }^{13} \mathrm{C}\left\{{ }^{1} \mathrm{H}\right\}$ NMR

$\left(126 \mathrm{MHz}, \mathrm{CDCl}_{3}\right)$

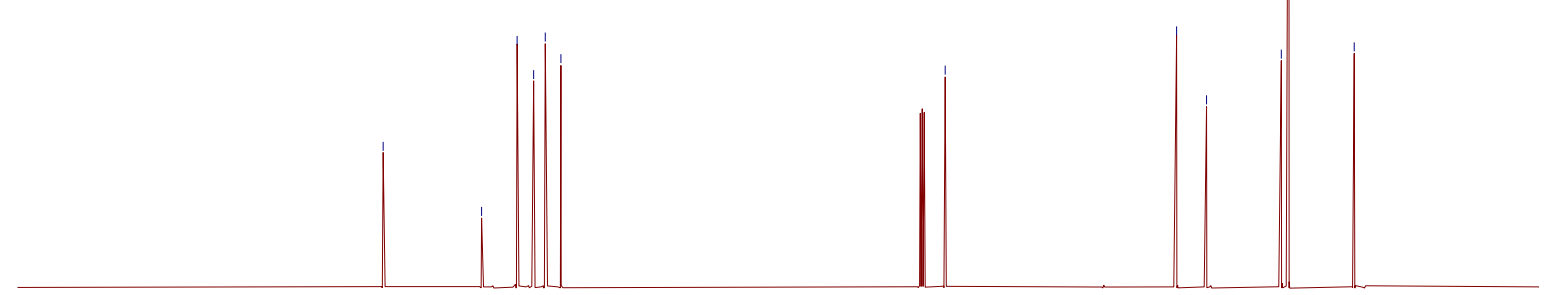

$\begin{array}{llllllllllllllllllll}190 & 180 & 170 & 160 & 150 & 140 & 130 & 120 & 110 & \begin{array}{c}100 \\ \mathrm{f} 1[\mathrm{ppm}]\end{array} & 80 & 70 & 60 & 50 & 40 & 30 & 20 & 10 & 0\end{array}$ 


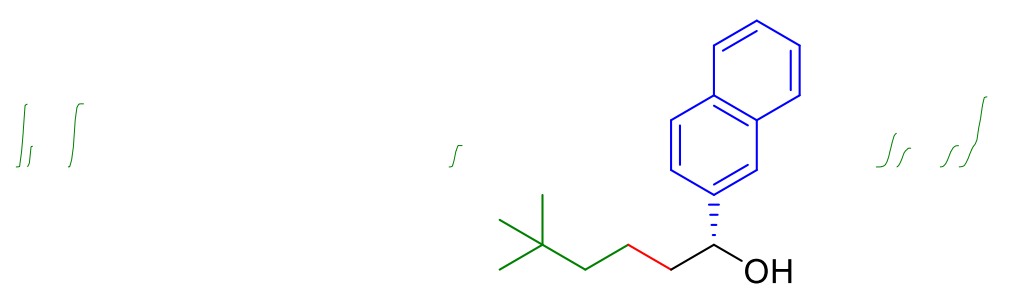

$6 a g$

${ }^{1} \mathrm{H}$ NMR

$\left(500 \mathrm{MHz}, \mathrm{CDCl}_{3}\right)$
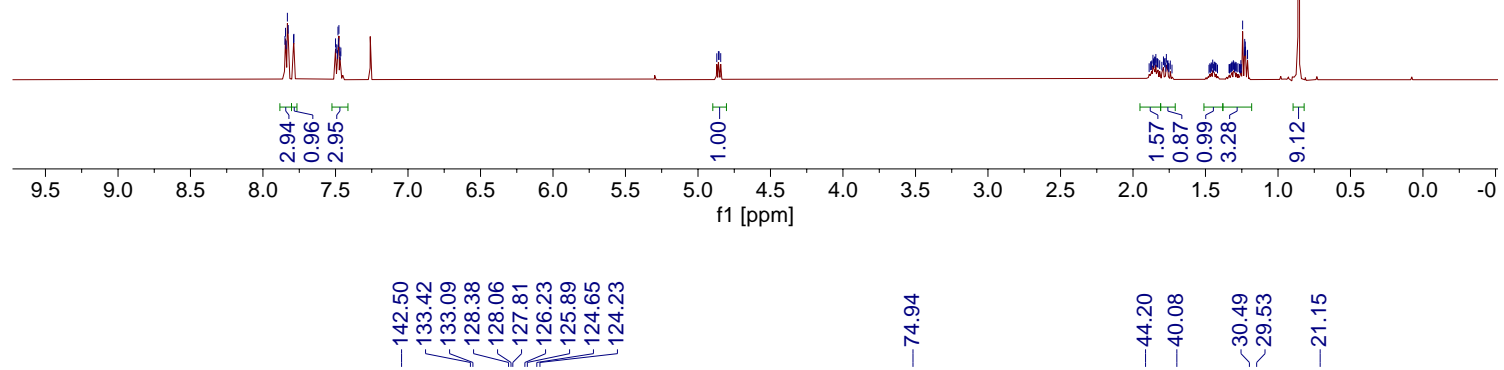

$\stackrel{\text { S }}{\stackrel{1}{+}}$

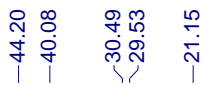

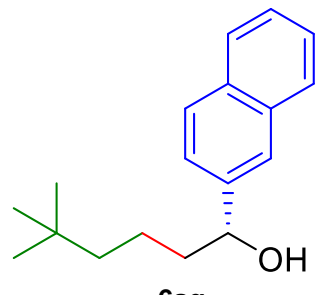

$6 \mathrm{ag}$

${ }^{13} \mathrm{C}\left\{{ }^{1} \mathrm{H}\right\}$ NMR

(126 MHz, $\mathrm{CDCl}_{3}$ )

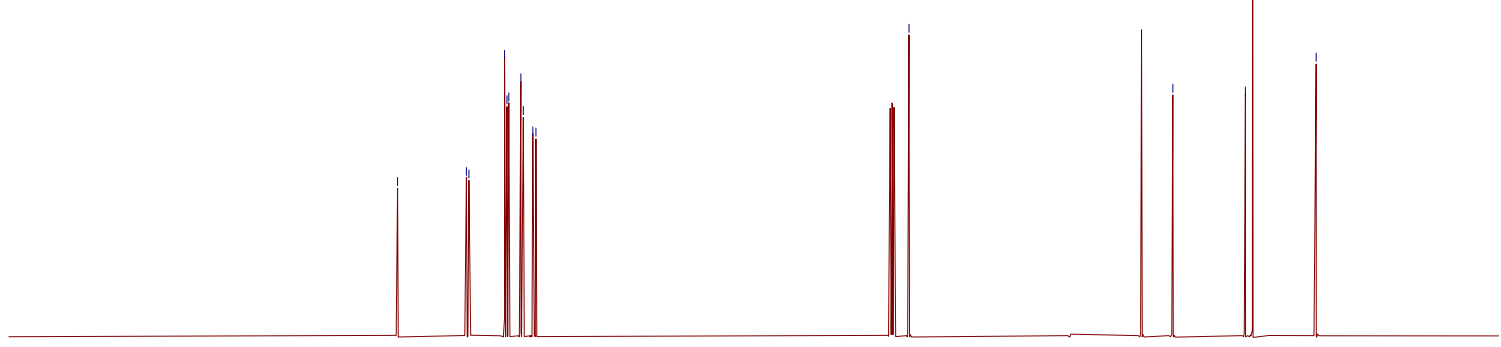

$\begin{array}{lllllllllllllllllllll}190 & 180 & 170 & 160 & 150 & 140 & 130 & 120 & 110 & \begin{array}{c}100 \\ \mathrm{f} 1\end{array}\left[\begin{array}{l}\mathrm{ppm}] \\ 1\end{array}\right. & 80 & 70 & 60 & 50 & 40 & 30 & 20 & 10 & 0\end{array}$ 

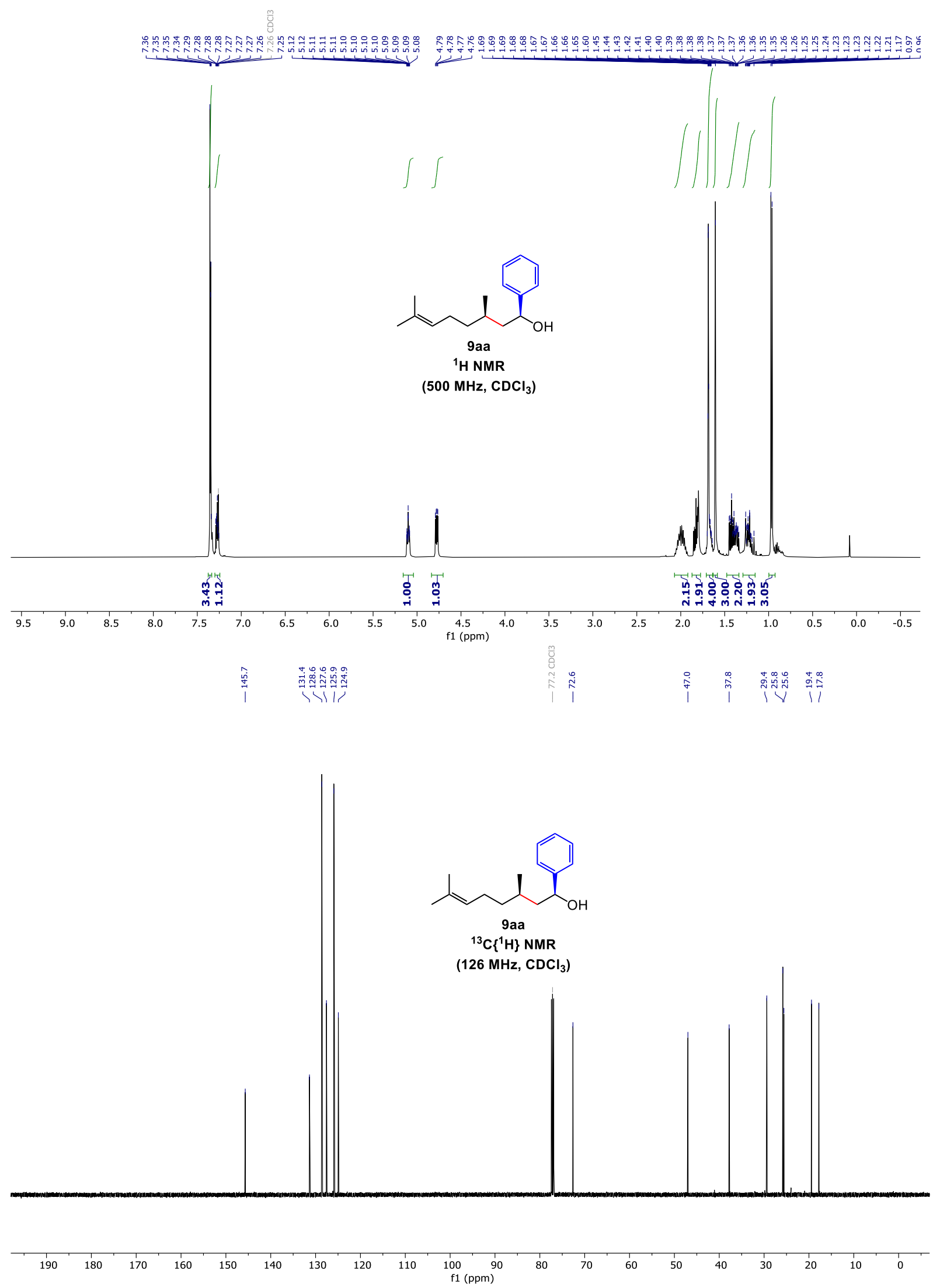

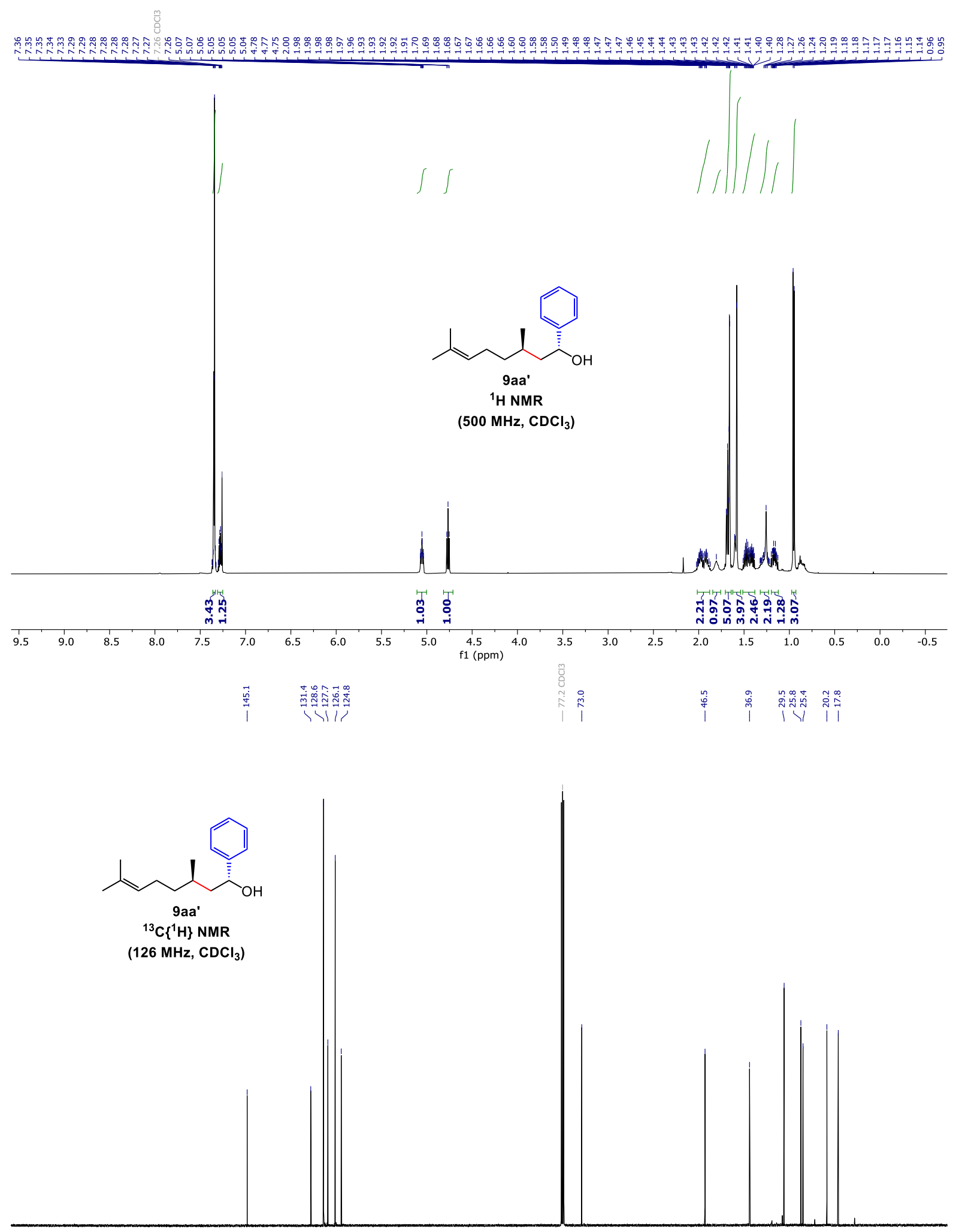

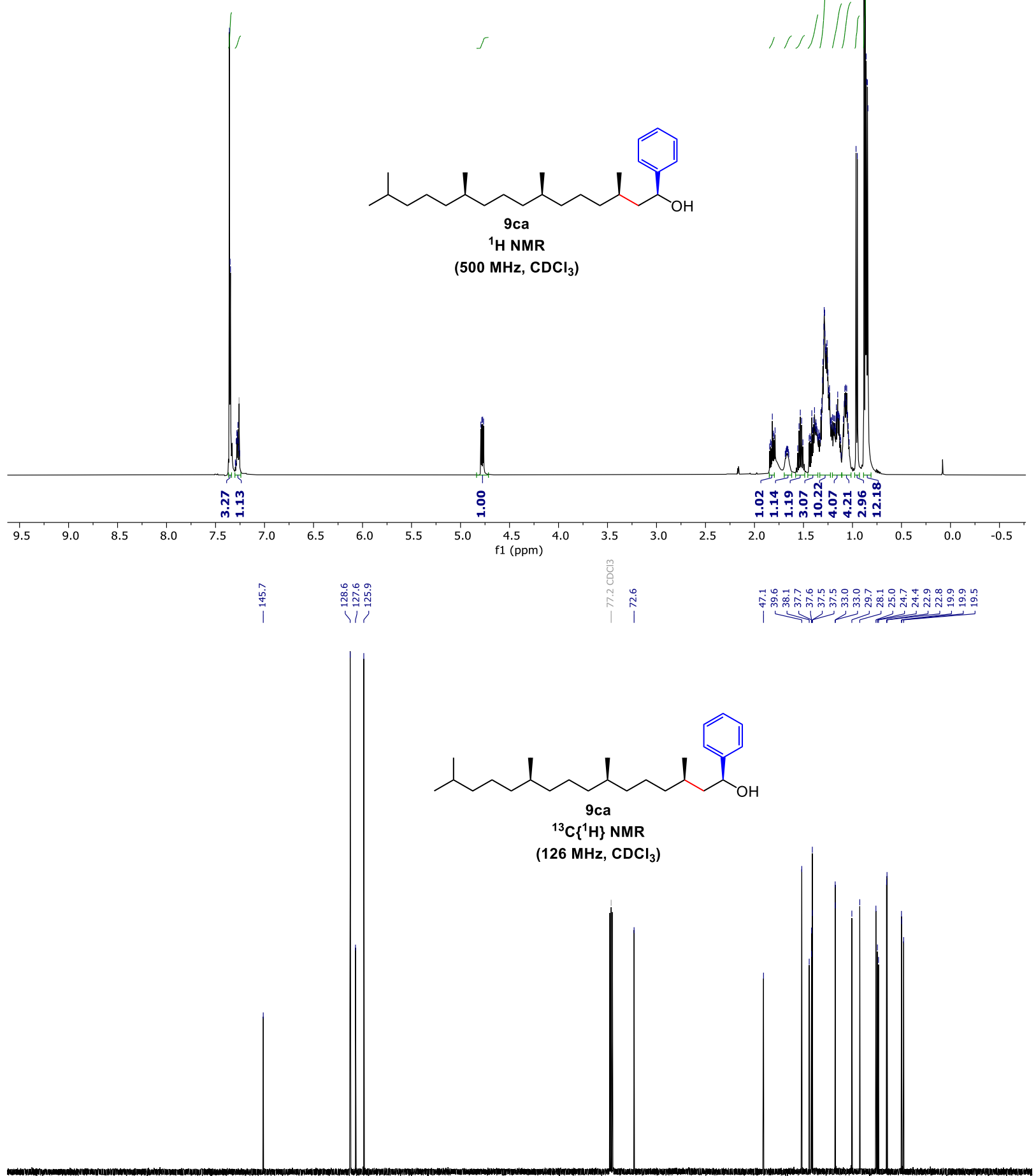

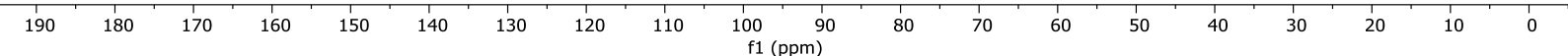



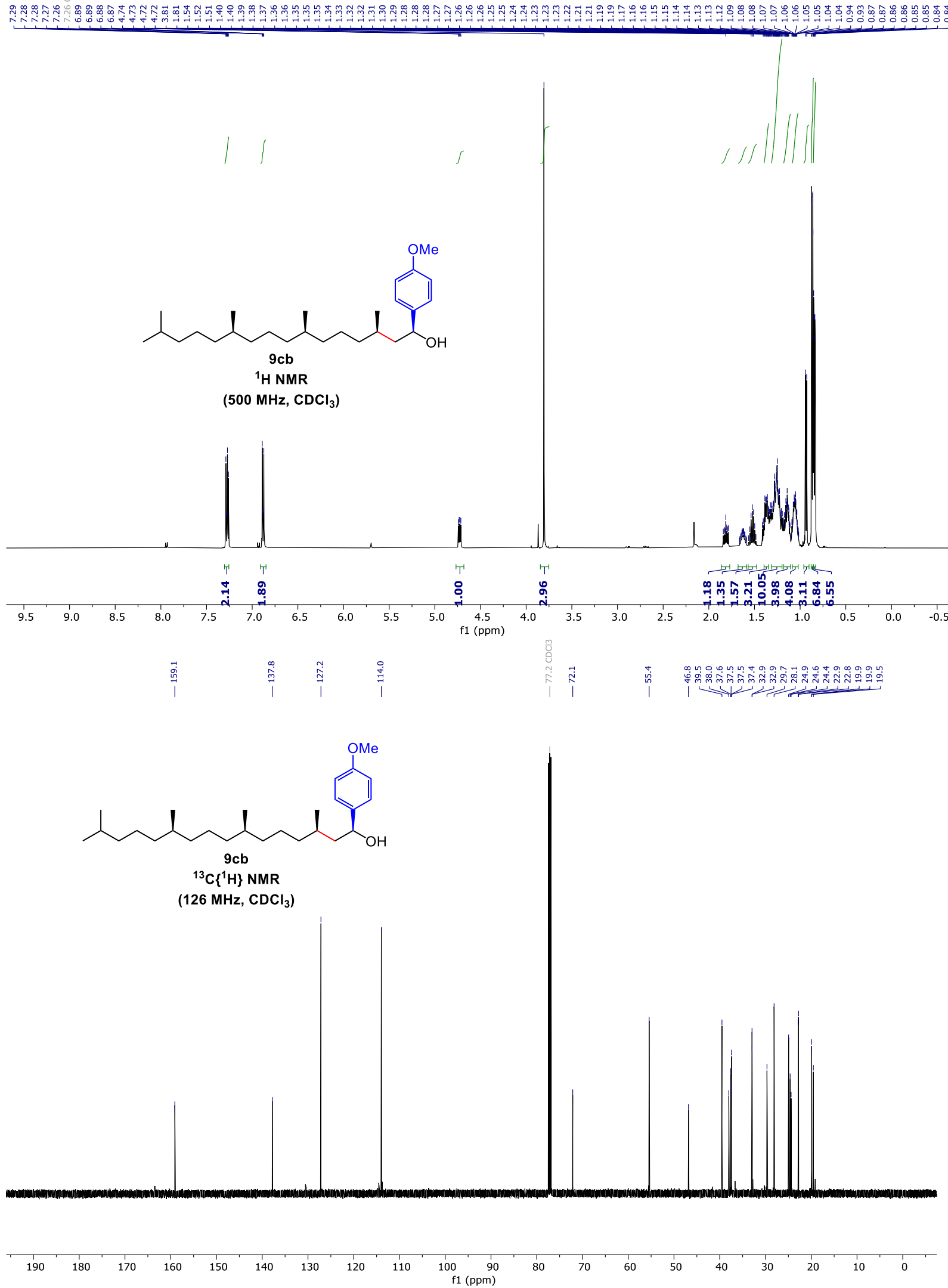

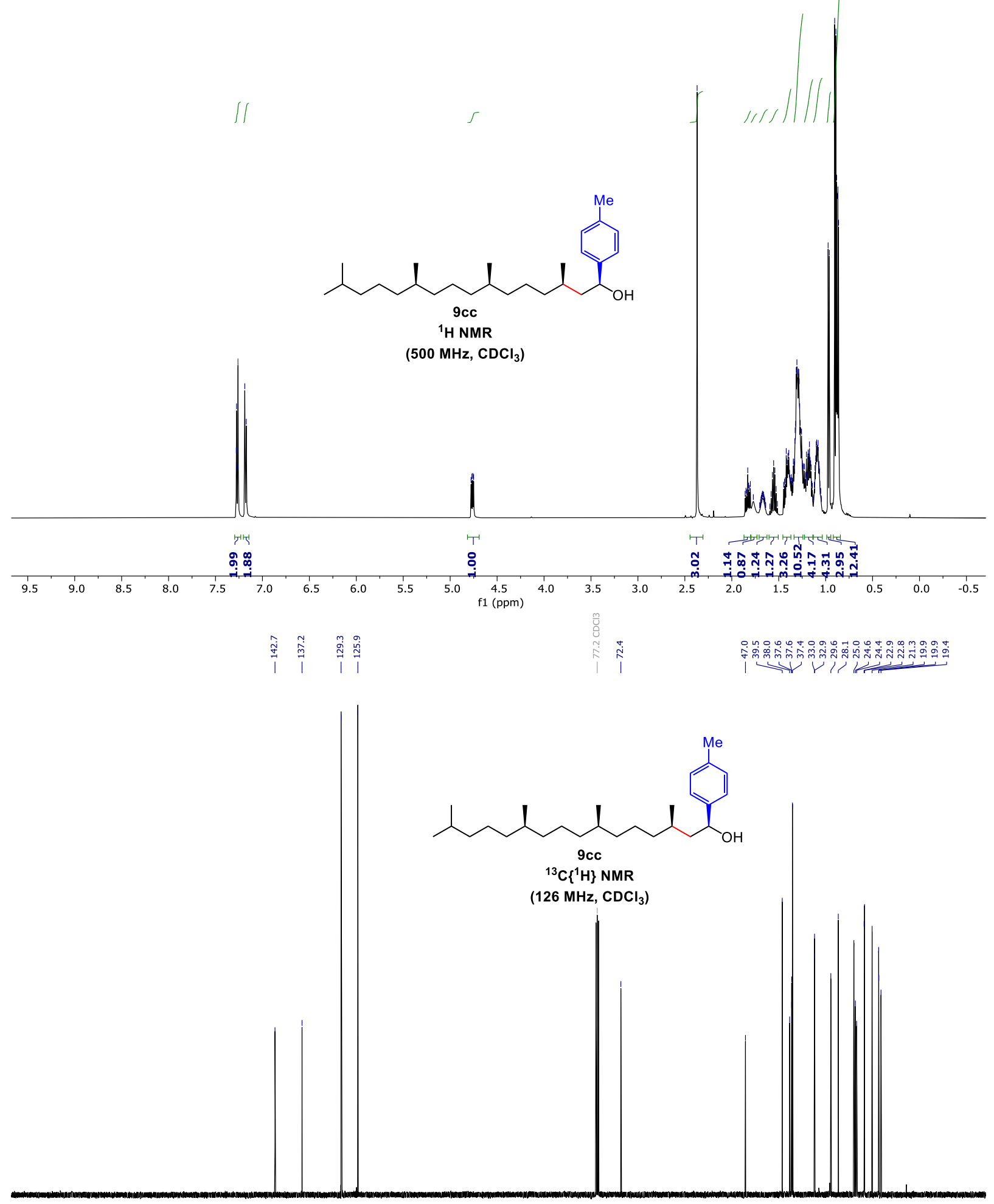

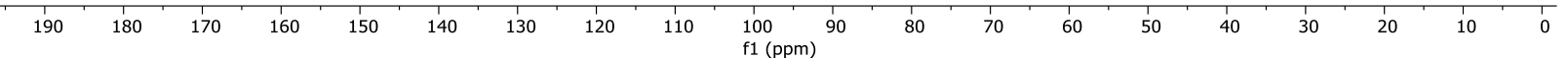




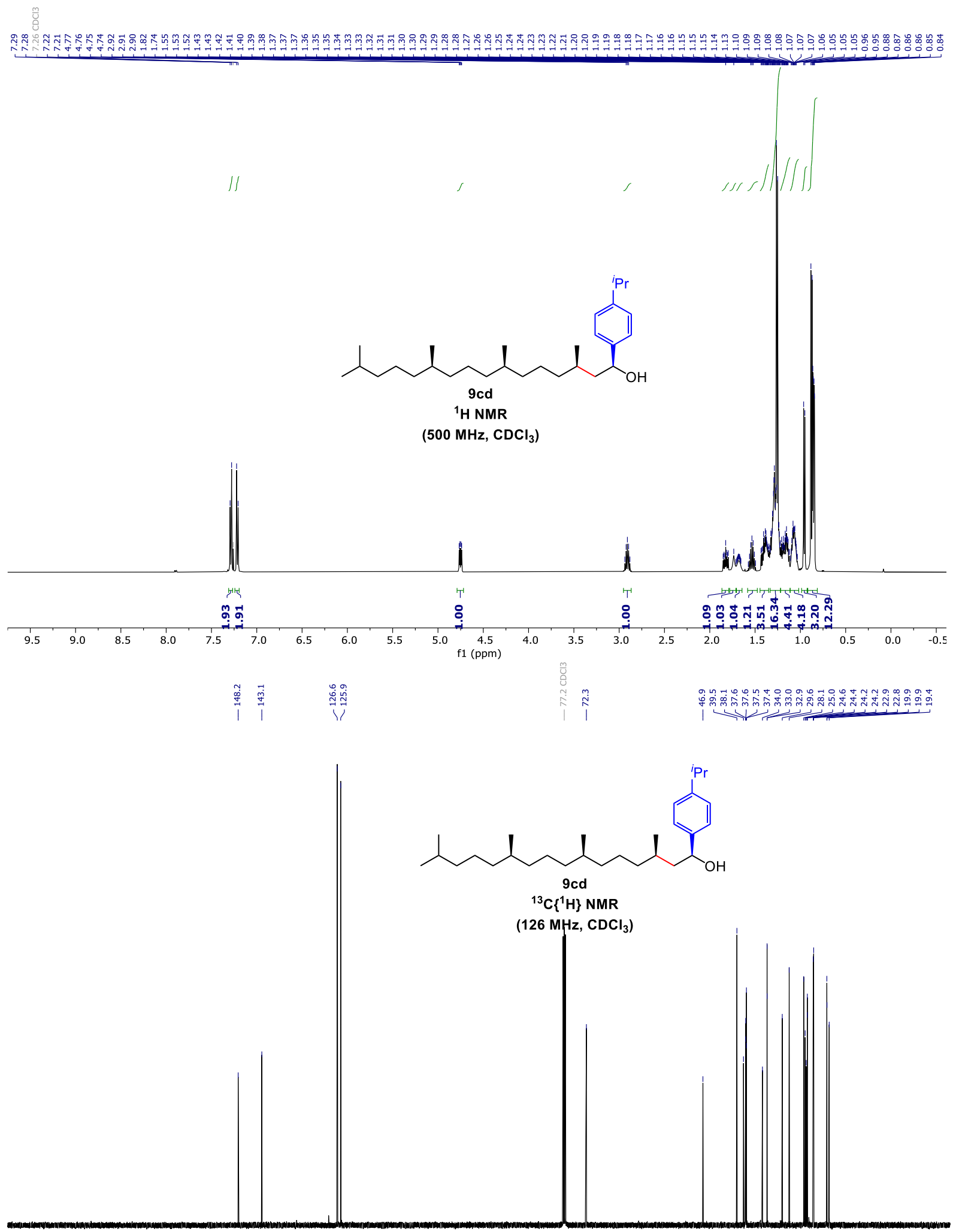

$\begin{array}{llllllllll}190 & 180 & 170 & 160 & 150 & 140 & 130 & 120 & 110 & \begin{array}{c}100 \\ \mathrm{f} 1(\mathrm{ppm})\end{array}\end{array}$

80

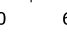

$60 \quad 50$

$\begin{array}{lllll}10 & 30 & 20 & 10 & 0\end{array}$ 


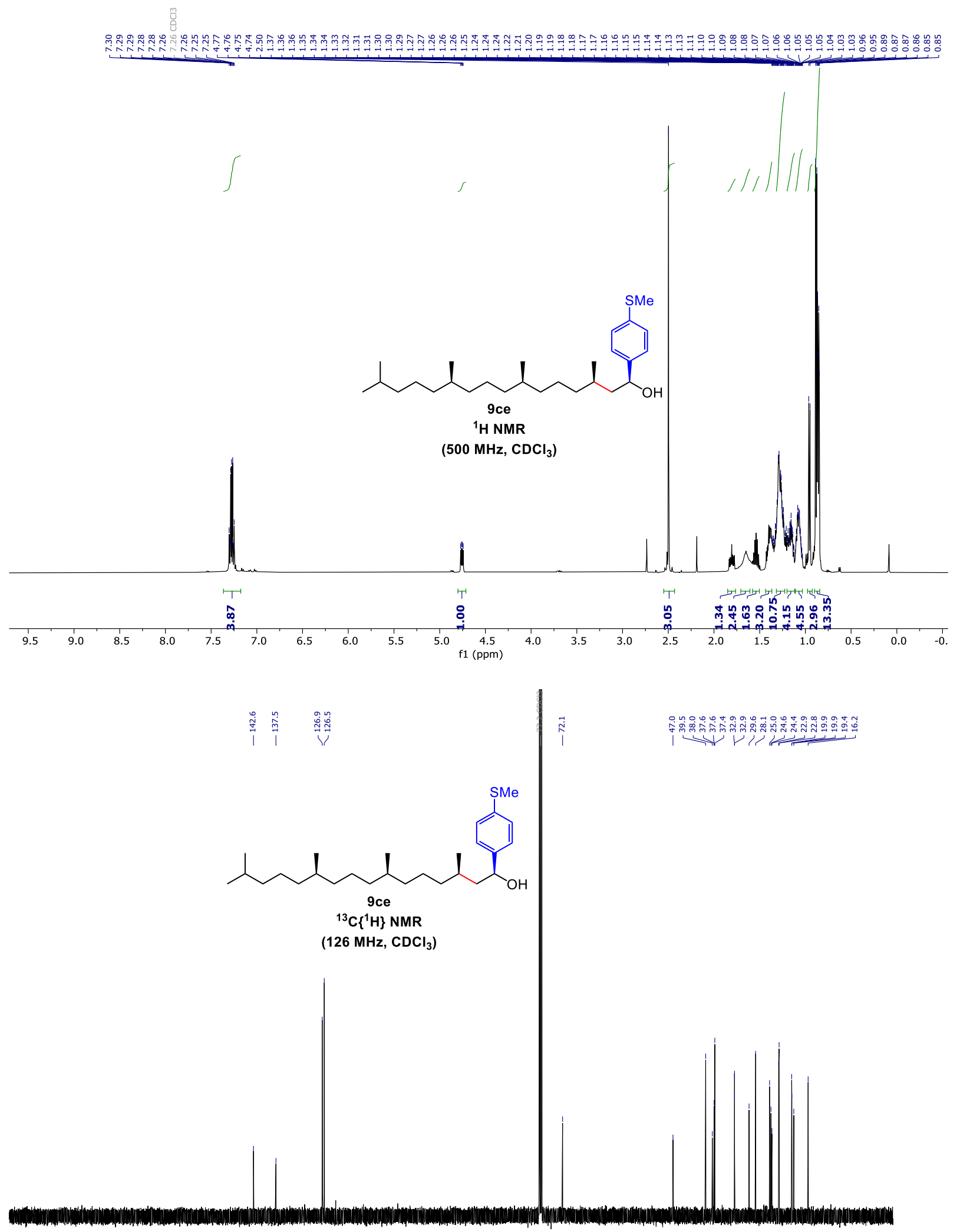

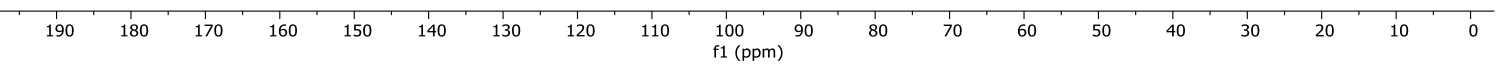



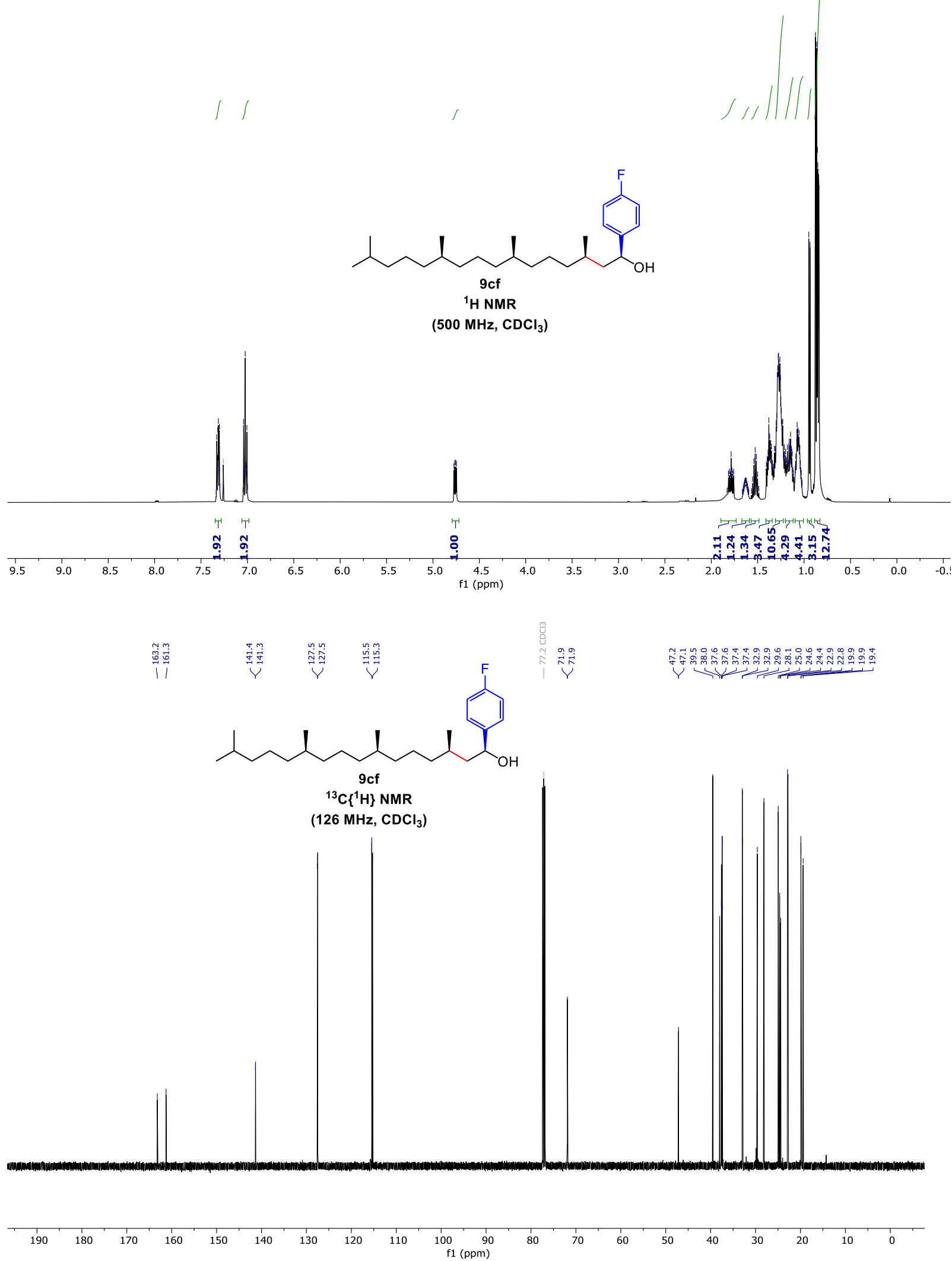


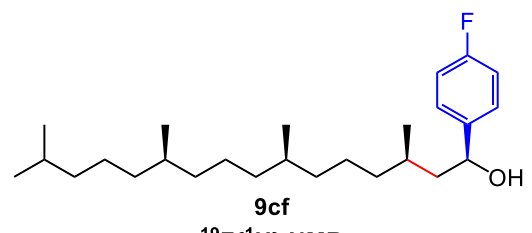

${ }^{19} \mathrm{~F}\left\{{ }^{1} \mathrm{H}\right\}$ NMR

(376 $\mathrm{MHz}, \mathrm{CDCl}_{3}$ )

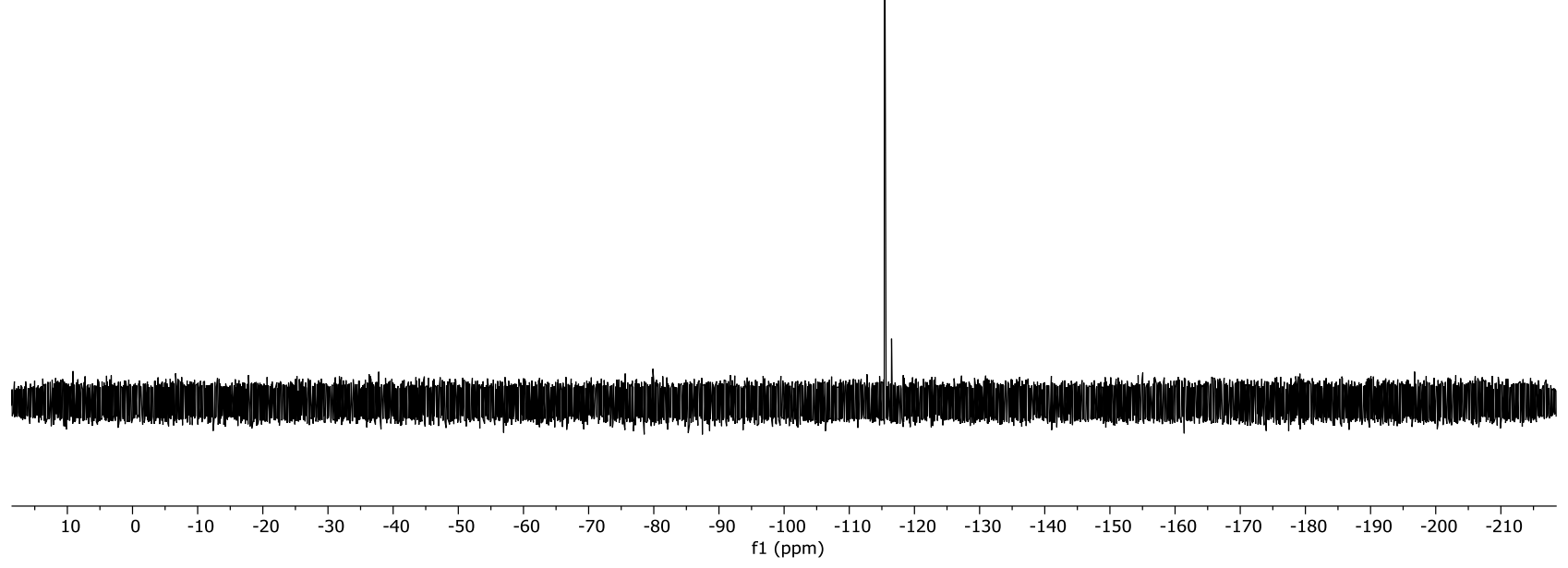




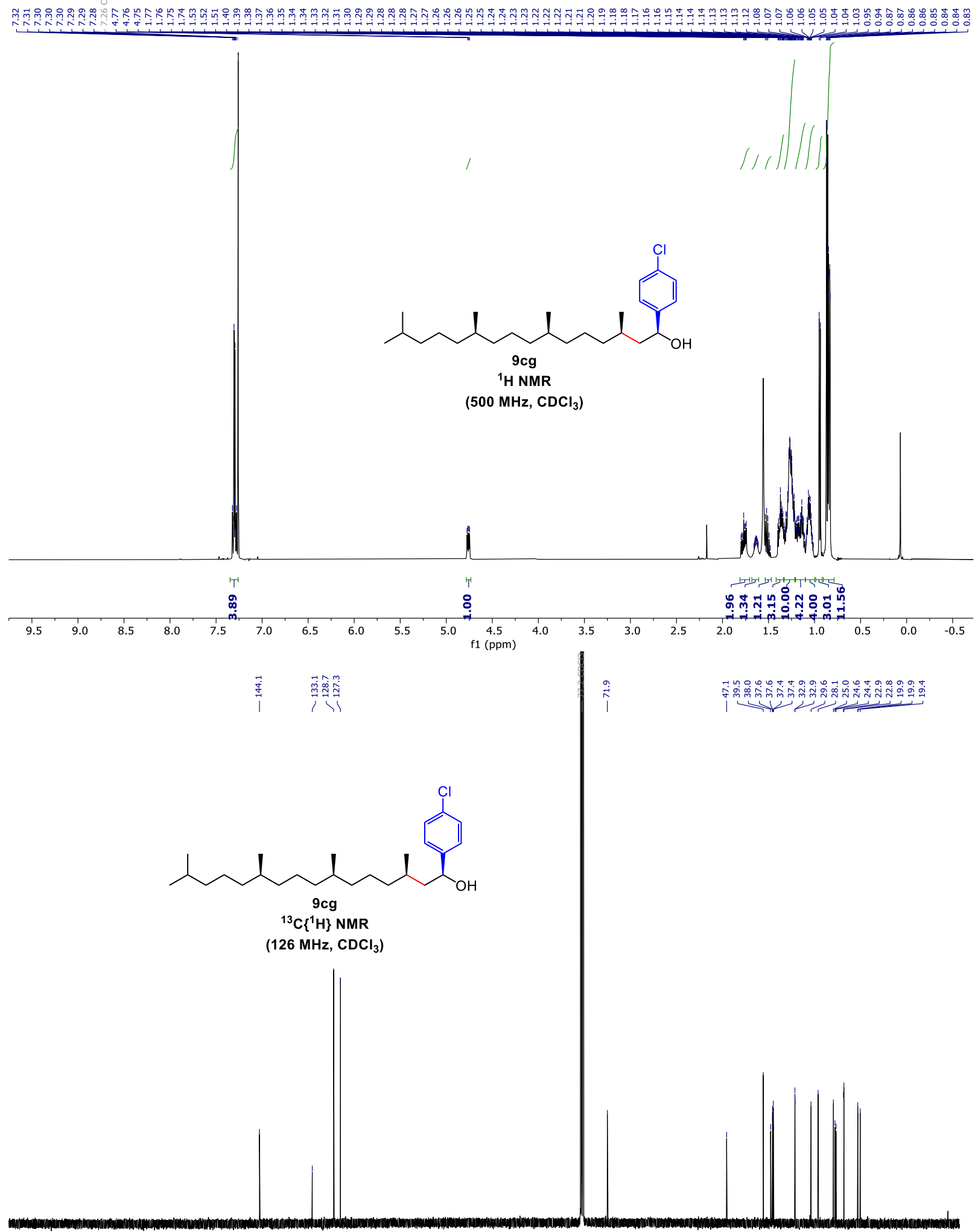

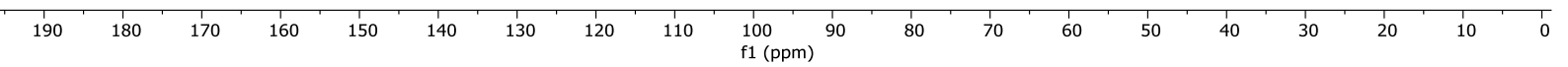



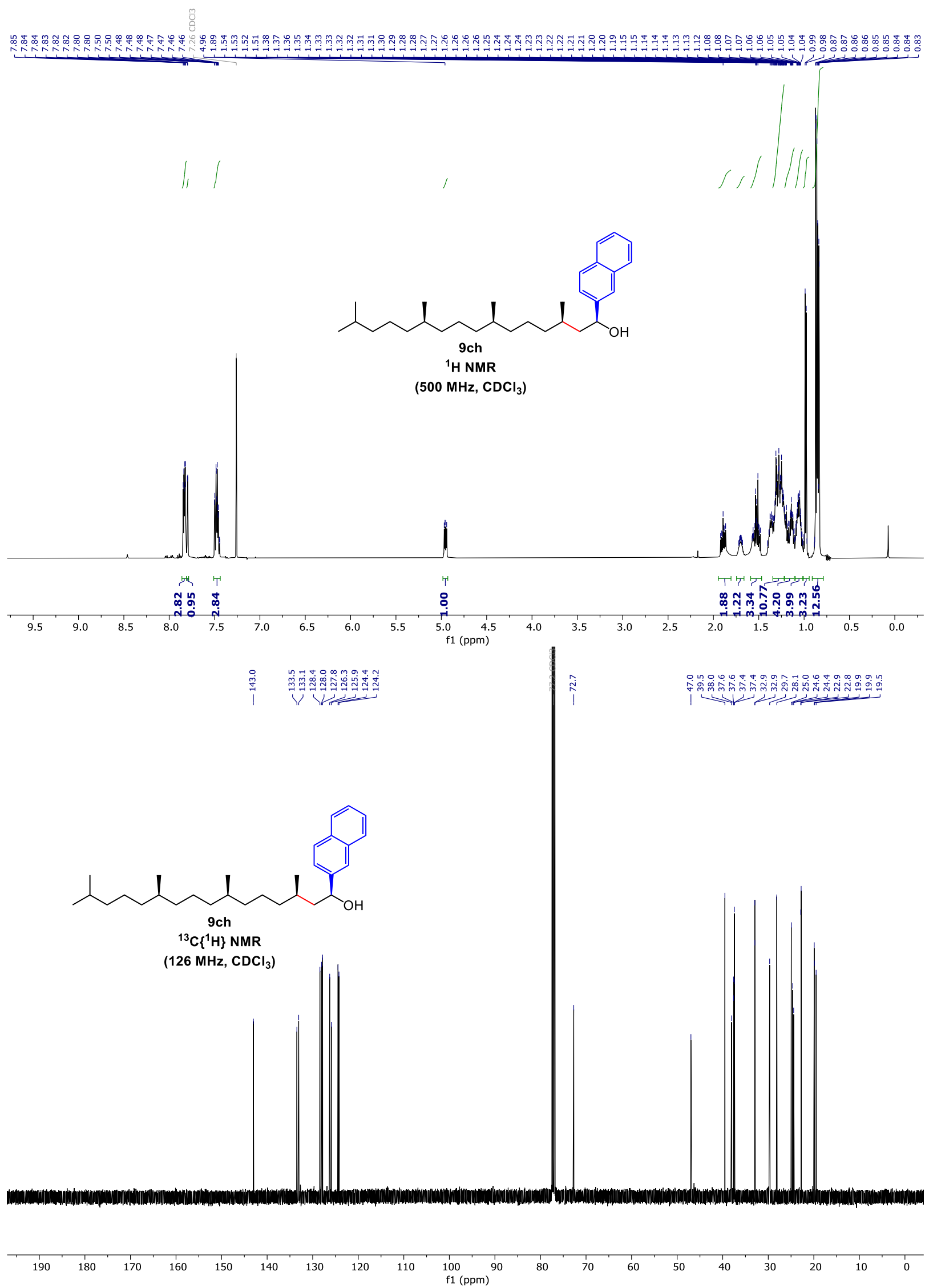


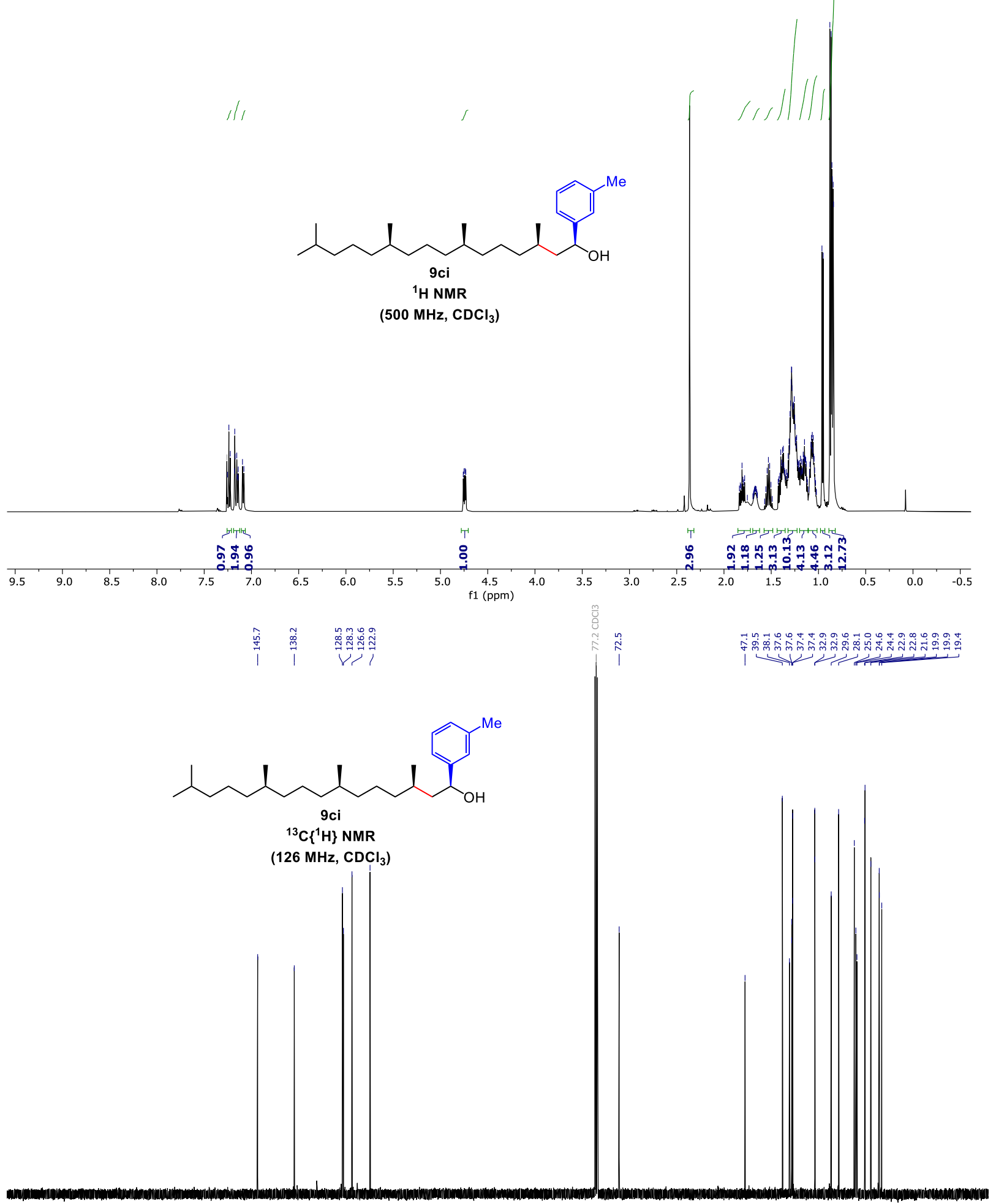

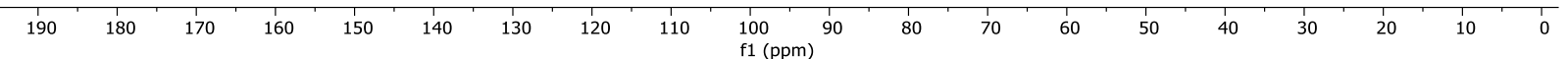



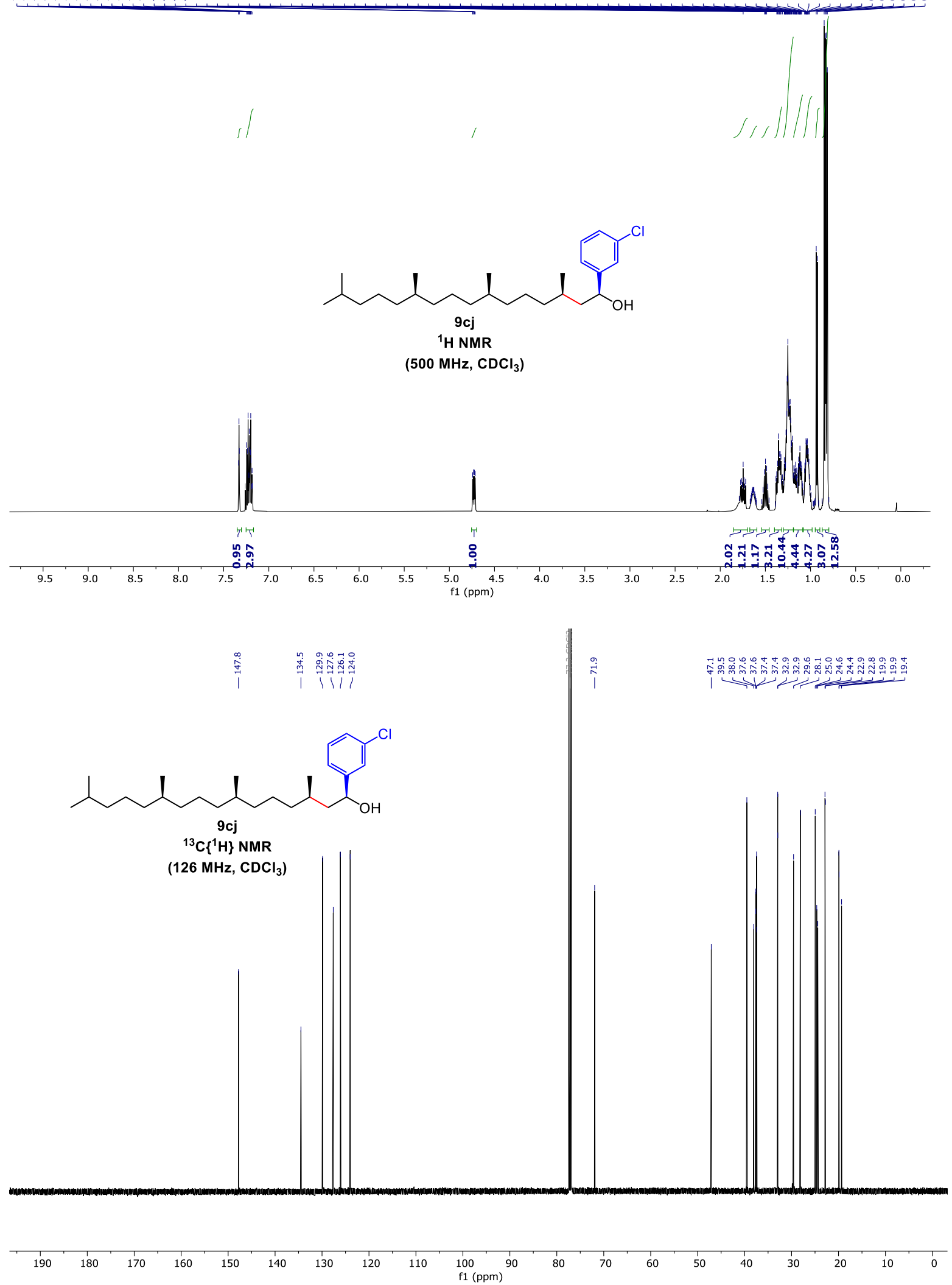

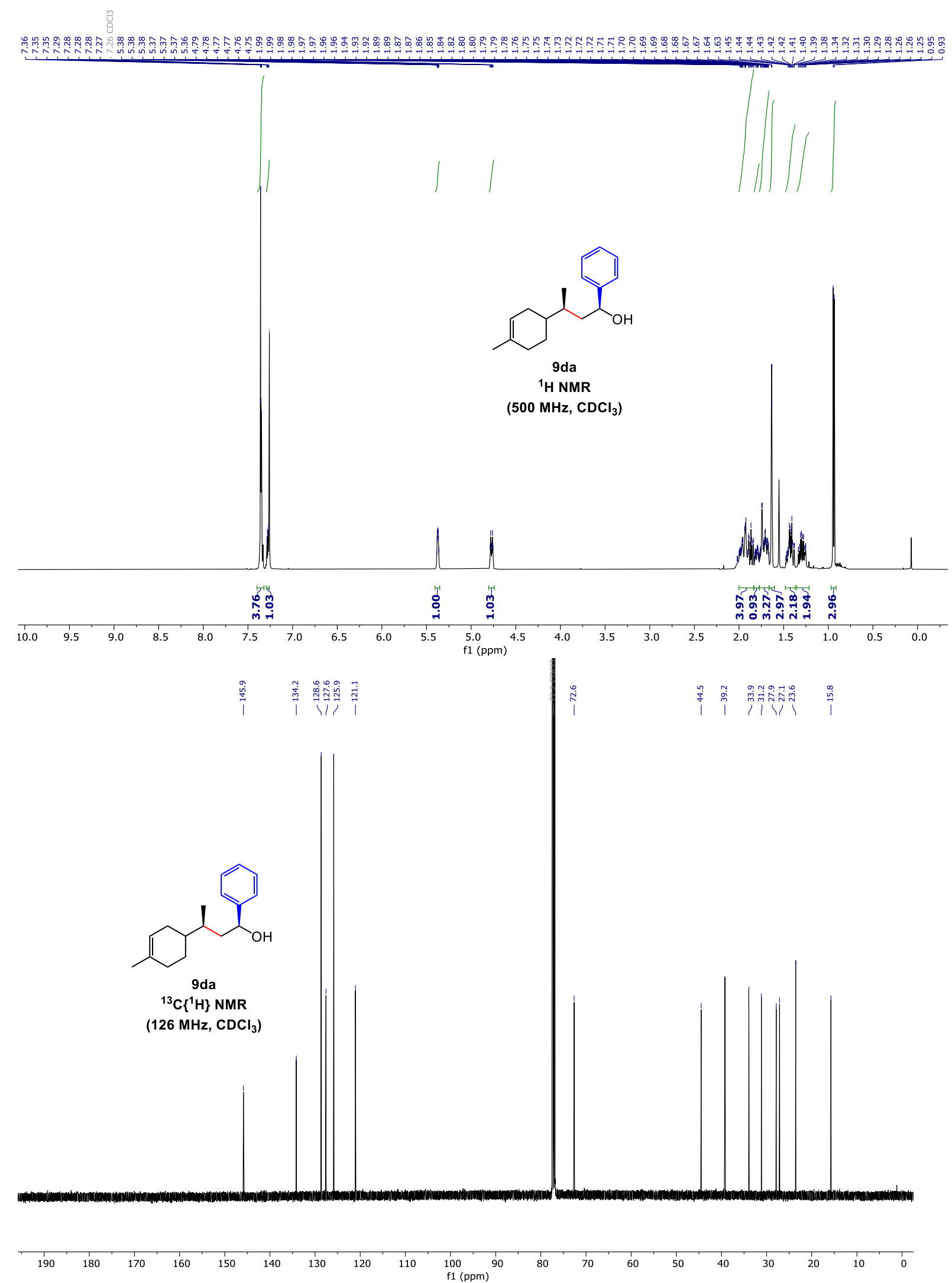


\section{CHIRAL SFC TRACES}

3aa
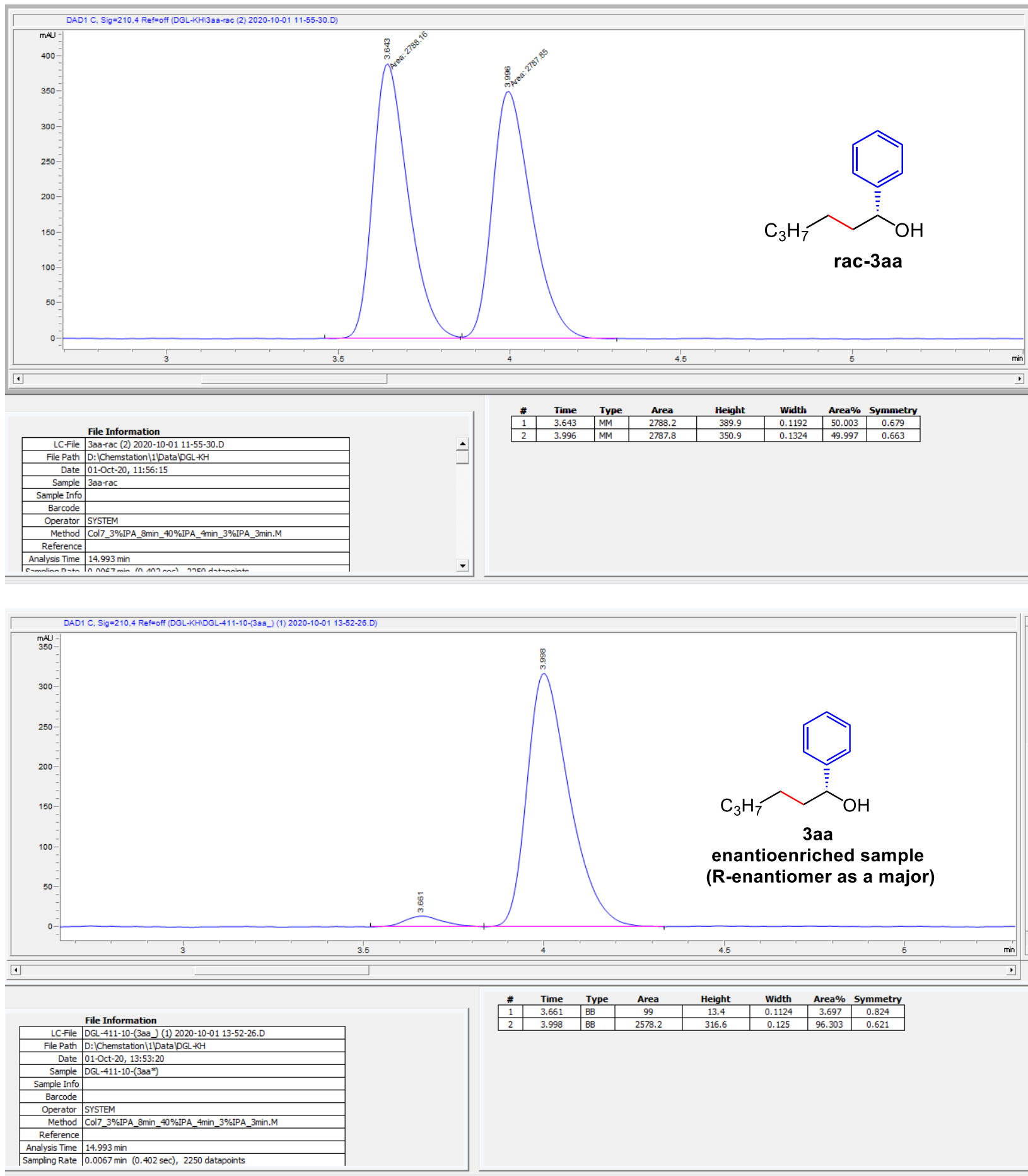
$3 a b$
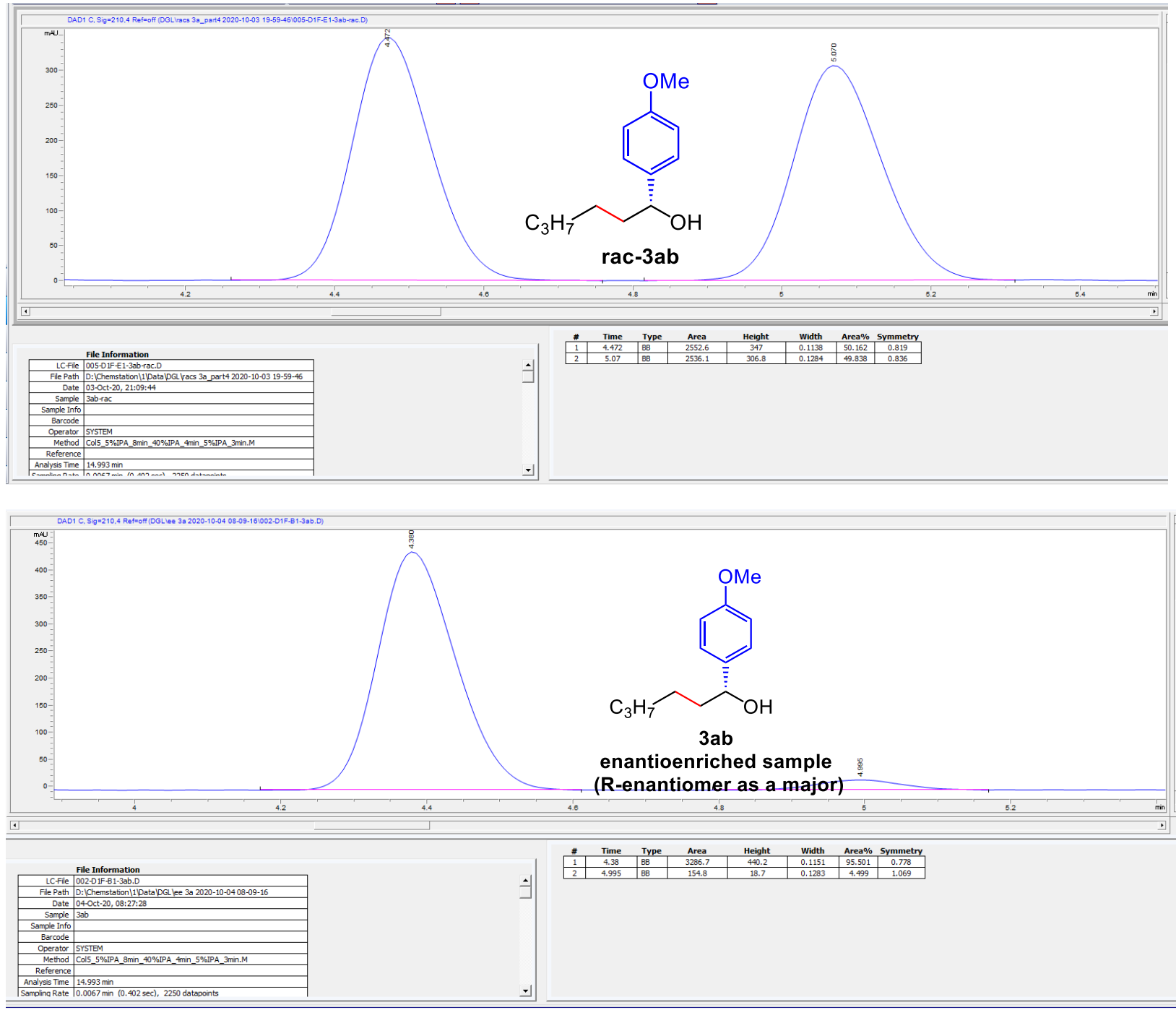
3ac
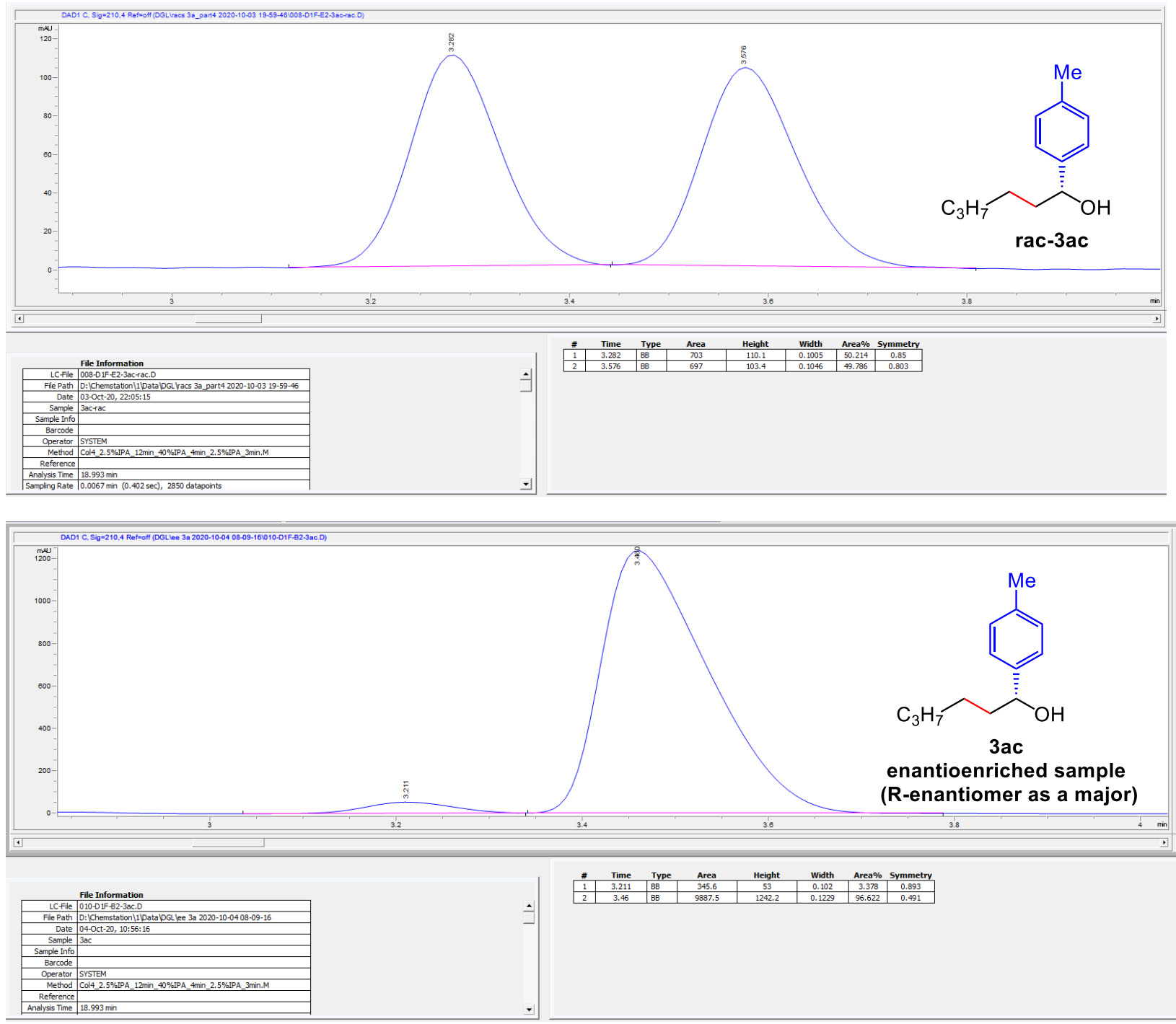
3ad
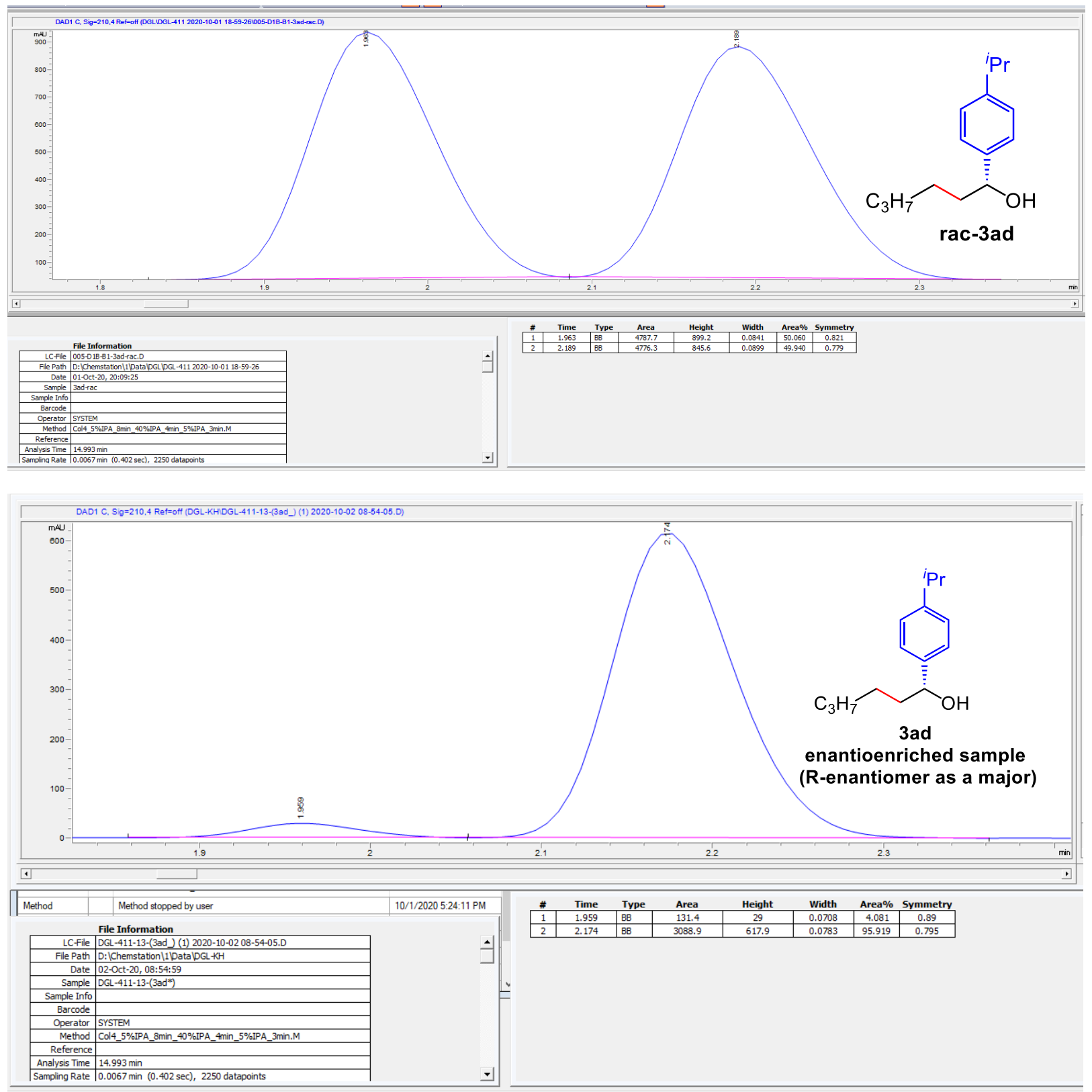
3ae
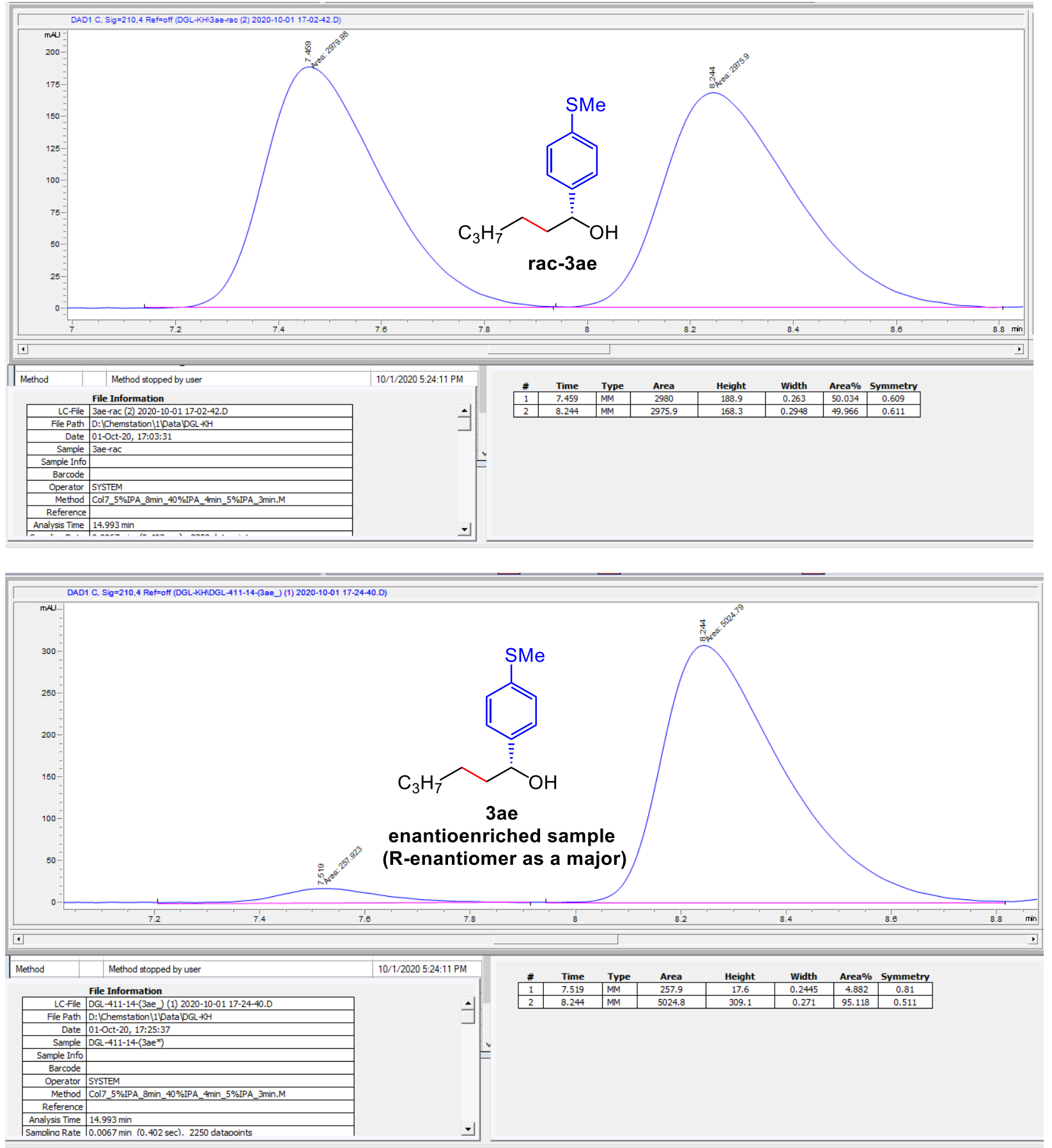
3af - Standard conditions $\left(60^{\circ} \mathrm{C}, 6 \mathrm{~h}\right)$ - see main text
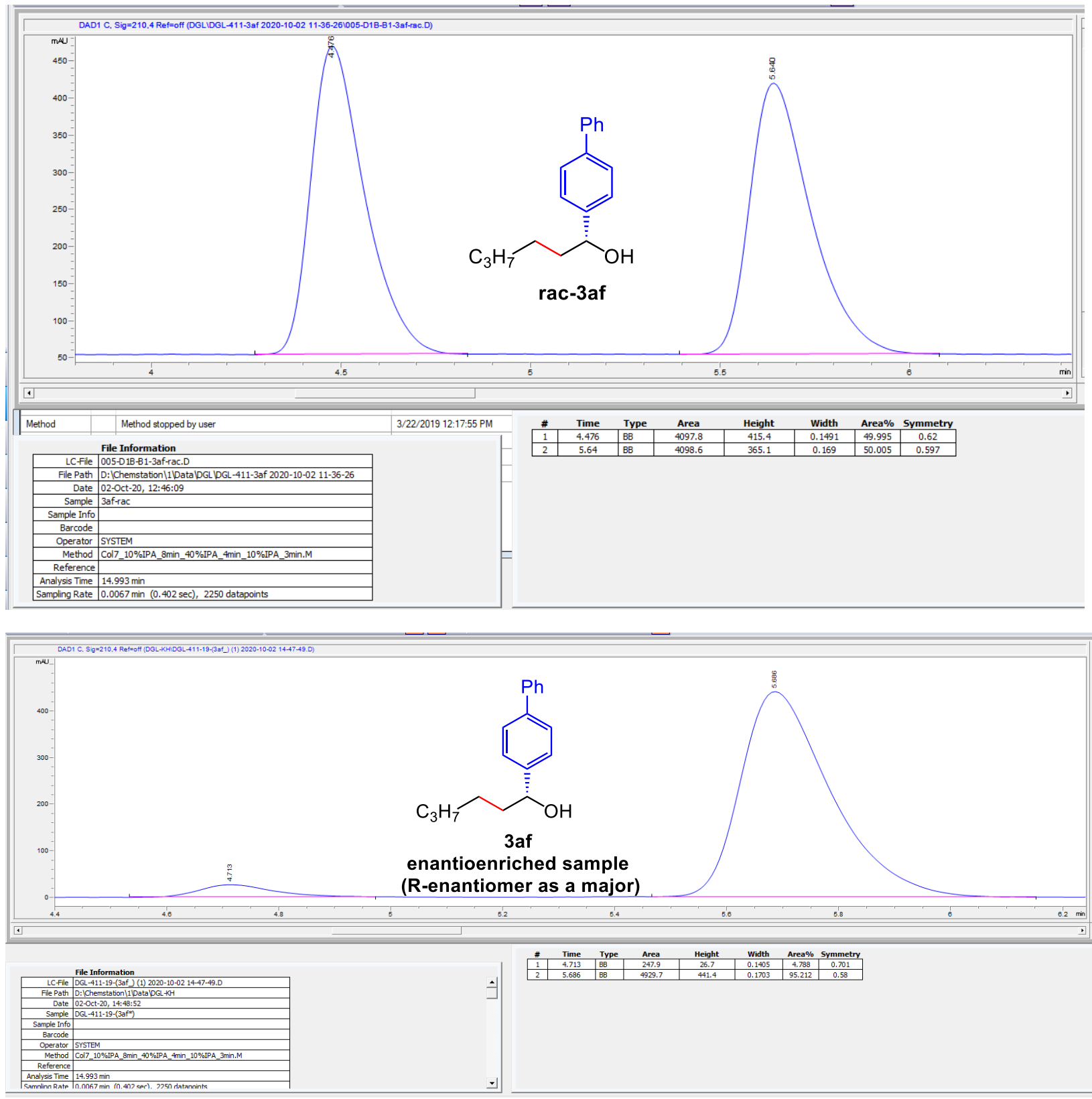
3af - Modified conditions $\left(90^{\circ} \mathrm{C}, 24 \mathrm{~h}\right)-$ see main text
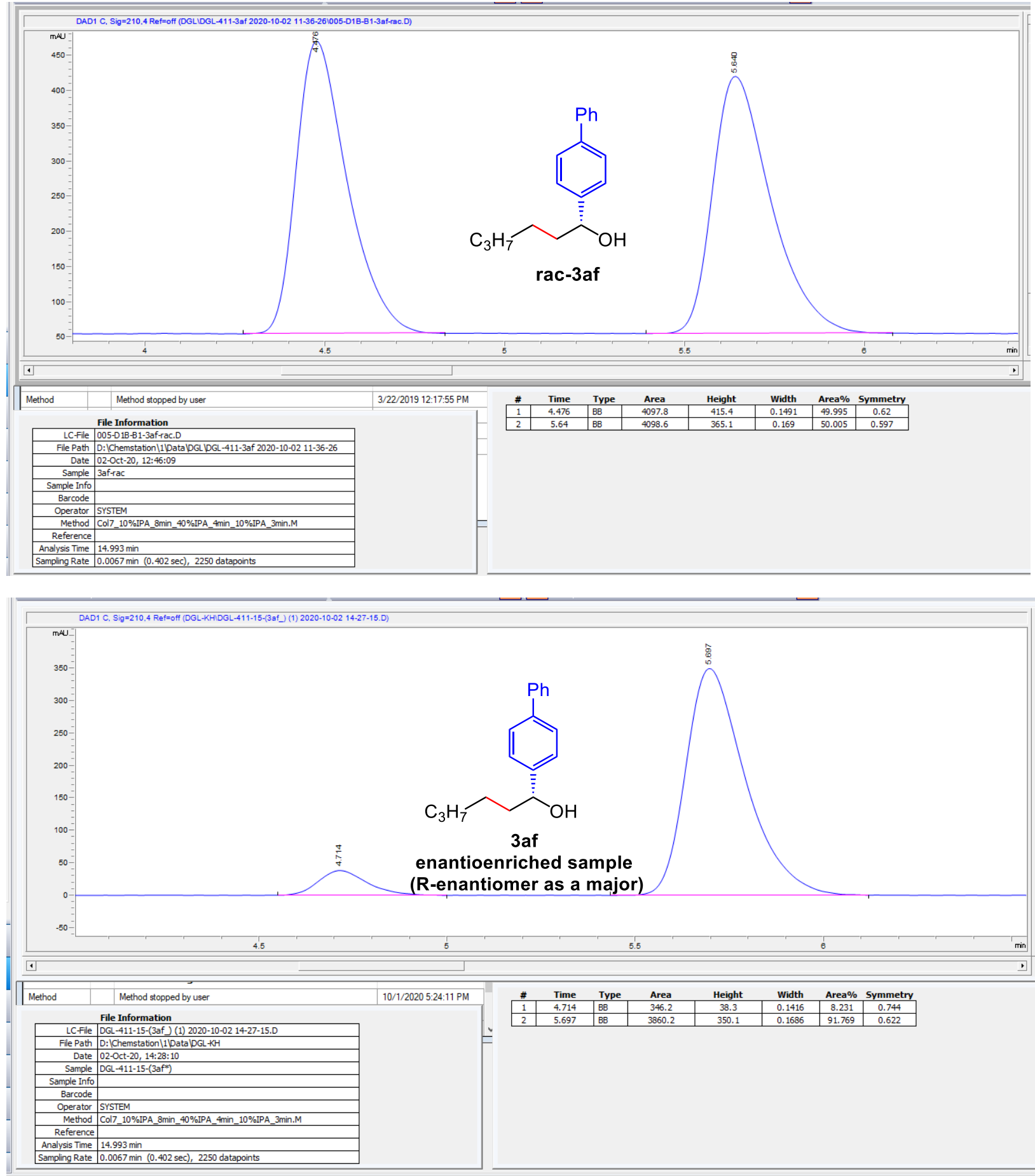
3ag
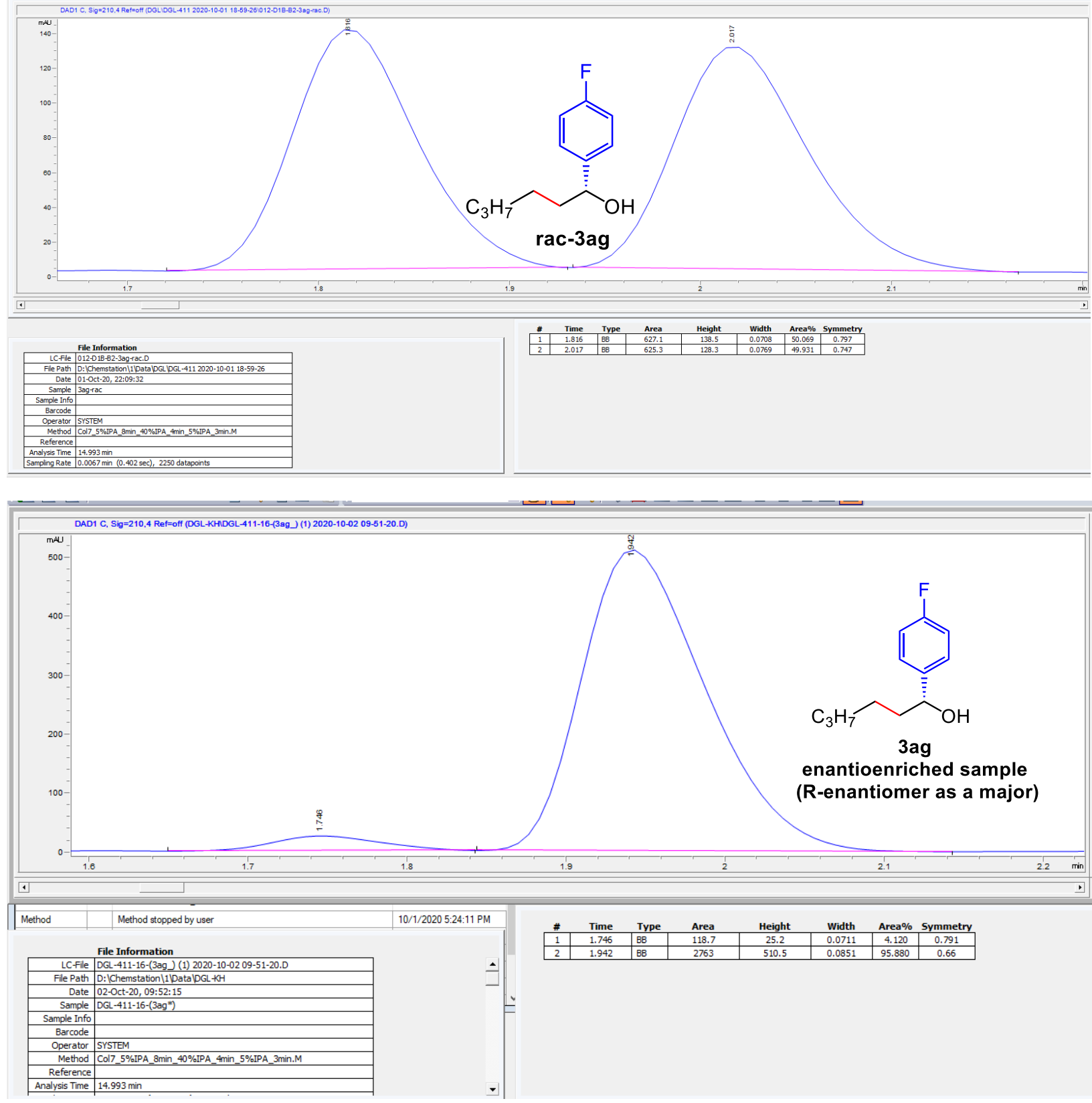
3ah
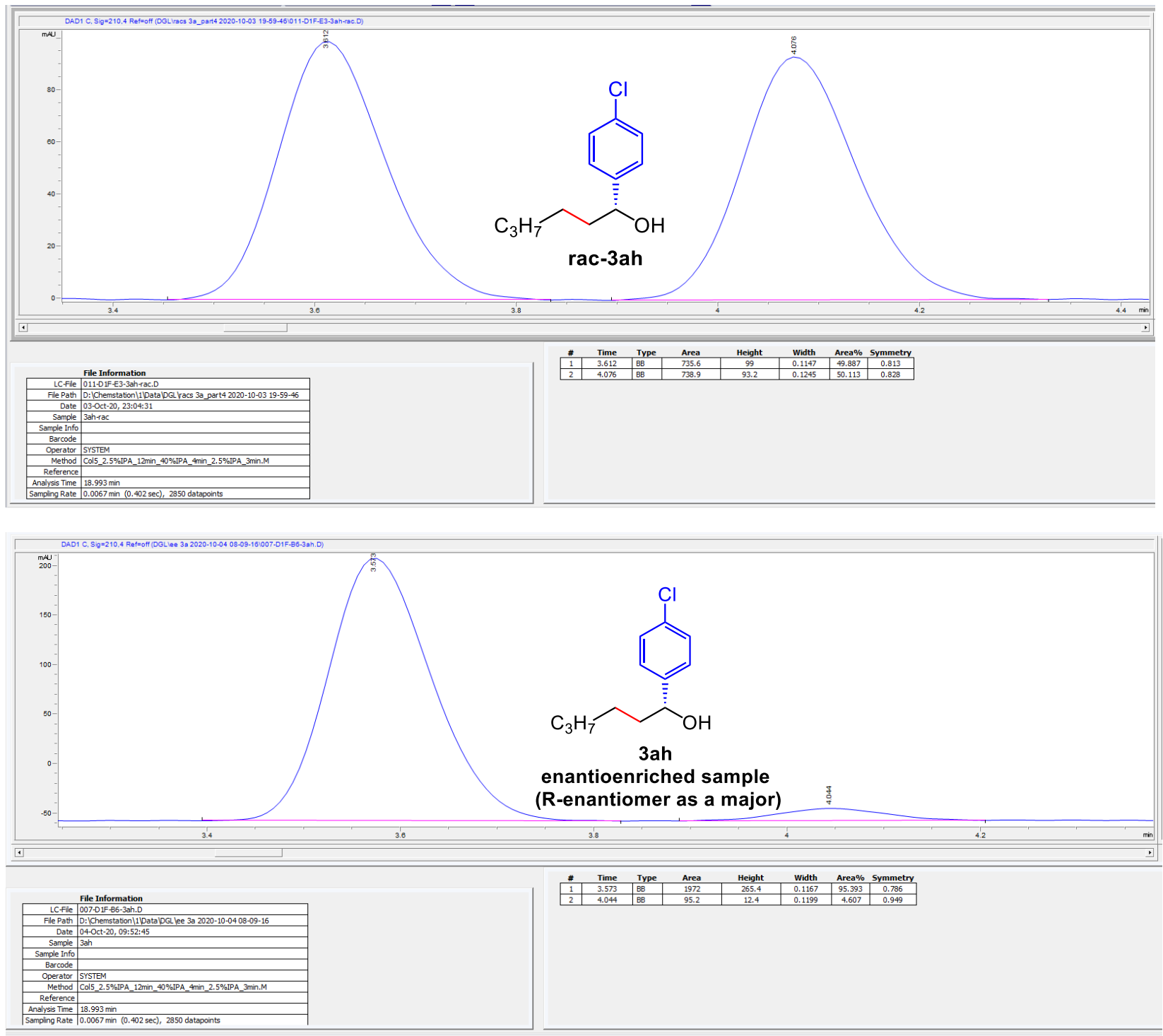
$3 a i$
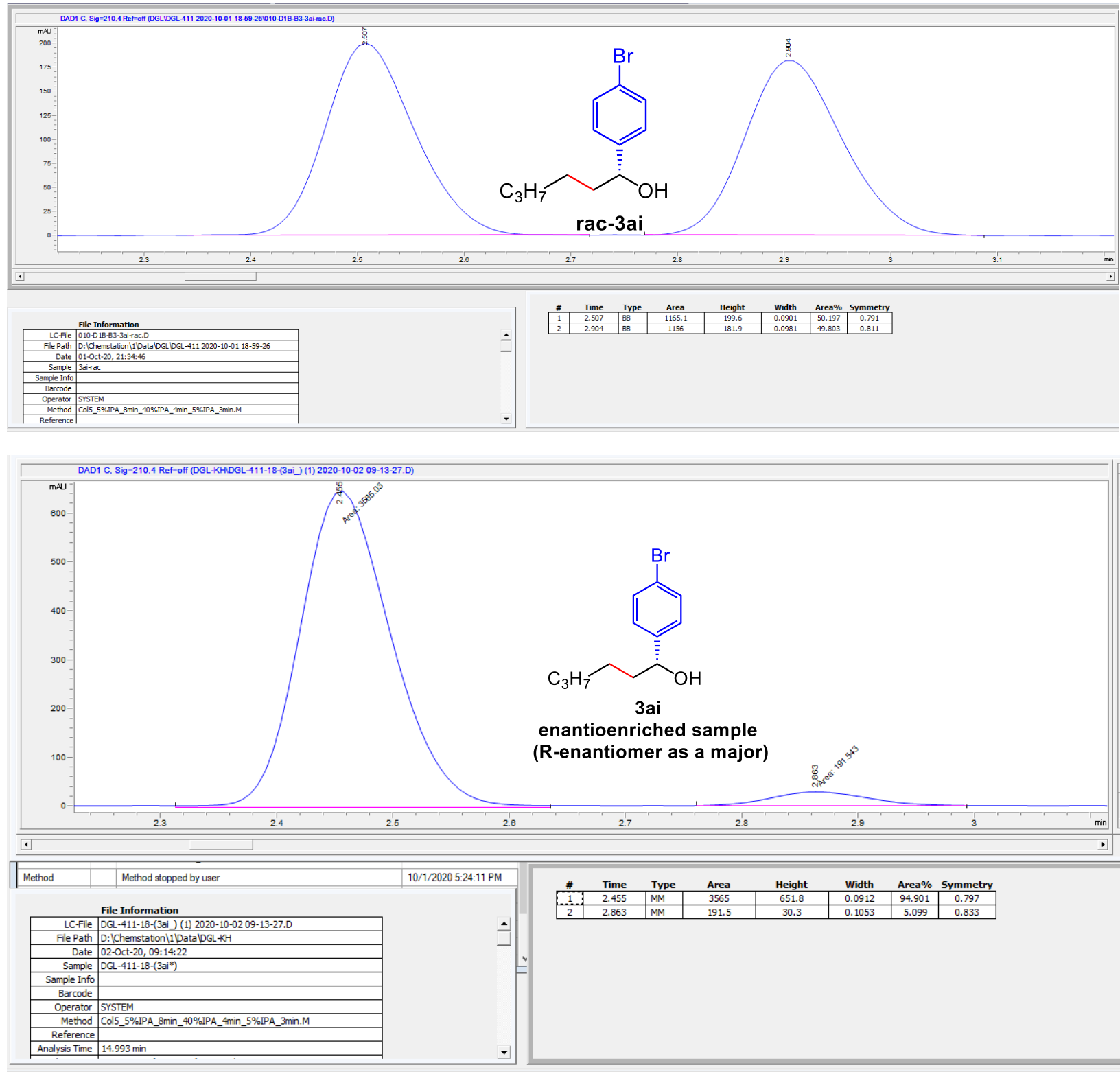
3aj

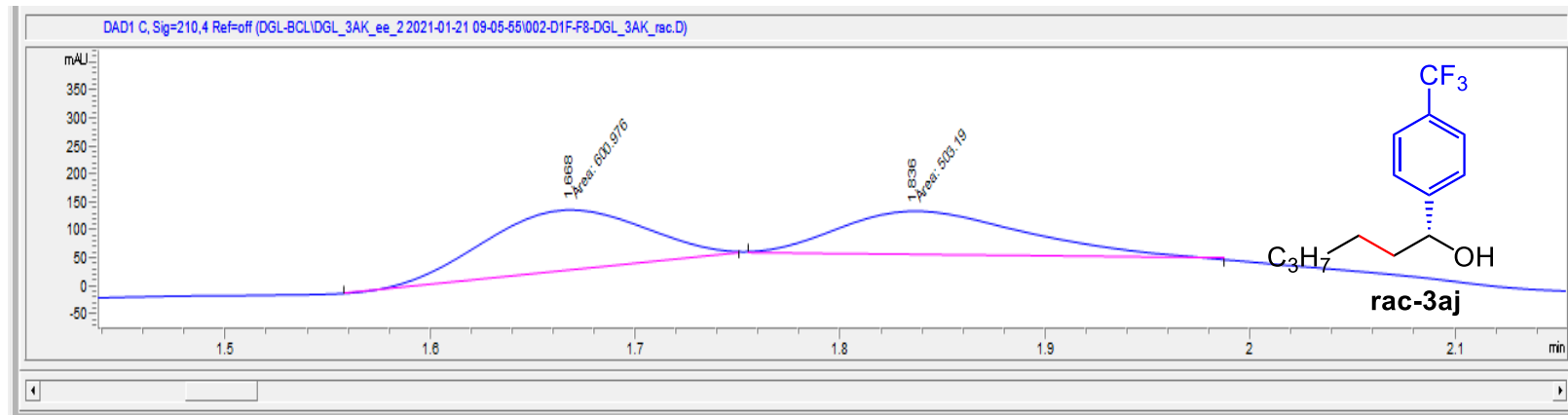

\begin{tabular}{|c|c|c|c|c|c|}
\multicolumn{1}{c}{ \# } & \multicolumn{1}{c}{ Time } & \multicolumn{1}{c}{ Area } & \multicolumn{1}{c}{ Height } & Width & \multicolumn{1}{c}{ Symmetry } \\
\hline 1 & 1.668 & 601 & 110.3 & 0.0908 & 1.204 \\
\hline 2 & 1.836 & 503.2 & 78.8 & 0.1064 & 0.669 \\
\hline
\end{tabular}

File Information LCFile 002 -D1FF8-DGL_3AK _rac,D

File Path D: |Chemstation|1Data DGL-BCL_DGL_3AK_ee_2 2021-01-2109-0 Date 21-Jan-21, 09:24:14

Sample DGL_3AK__ac

Sample Info

Barcode

Operator SYSTEM

Method Col5 0.5\% THF $8 \mathrm{~min} 40 \%$ THF $4 \mathrm{~min} 0.5 \%$ THF $3 \mathrm{minM}$

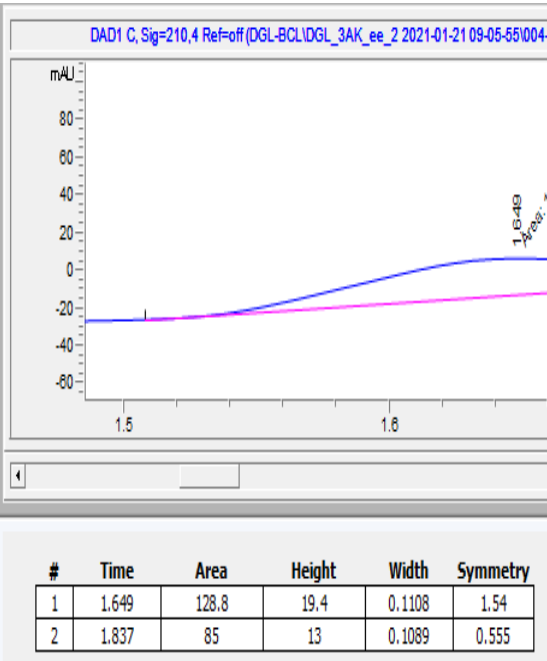

File Information

\begin{tabular}{|c|c|}
\hline LCFile & 004-DIFF9-DGL__AK__ee,D \\
\hline File Path & D:|Chemstation|1|Data DGL_BCLIDGL_3AK_ee_2 2021-01-21 09-05 \\
\hline Date & 21-Jan-21, 09:58:23 \\
\hline Sample & DGL_3AK_ee \\
\hline Sample Info & \\
\hline Barcode & \\
\hline Operator & SYSTEM \\
\hline
\end{tabular}


3ak
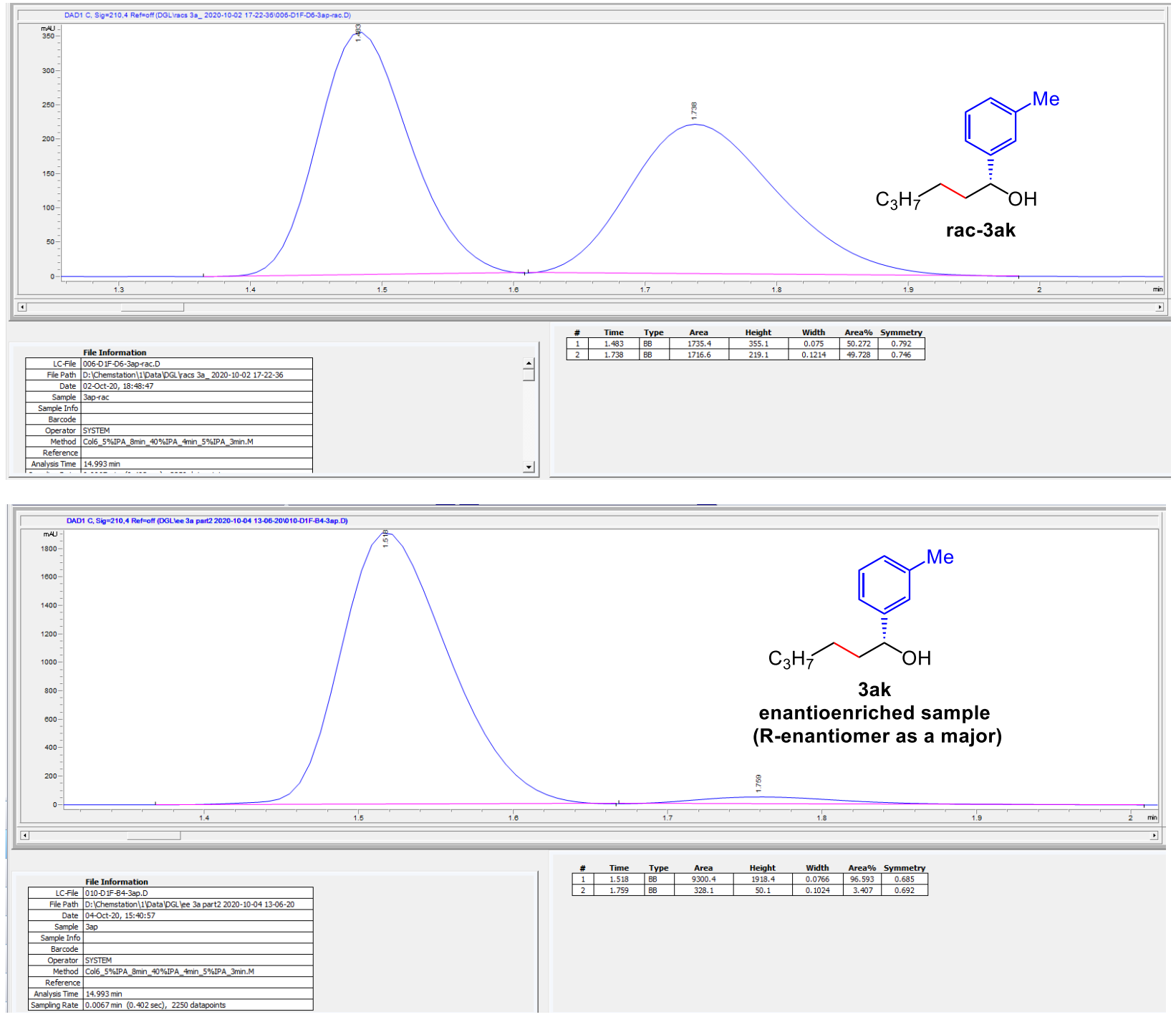
3al
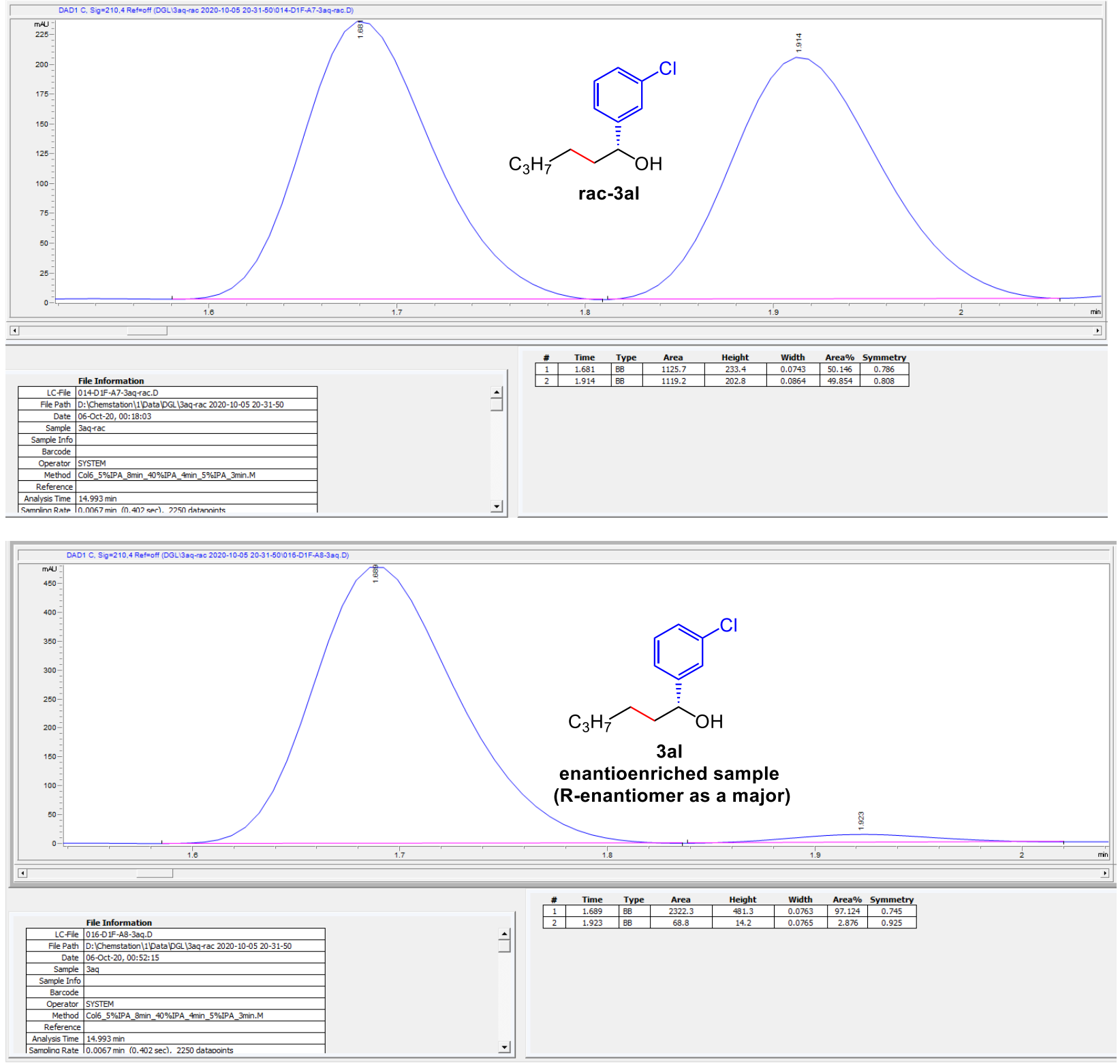
3am
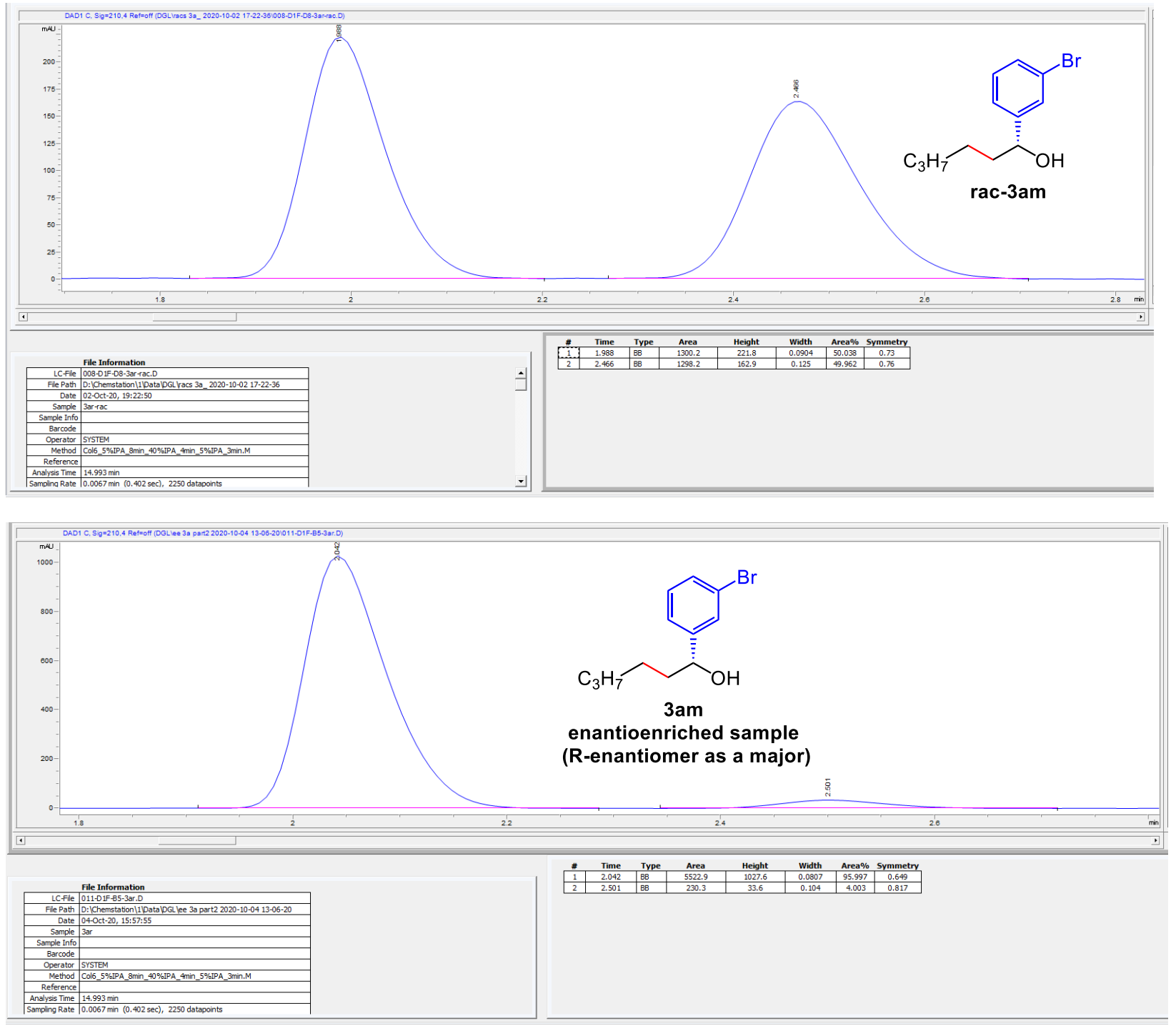
3an
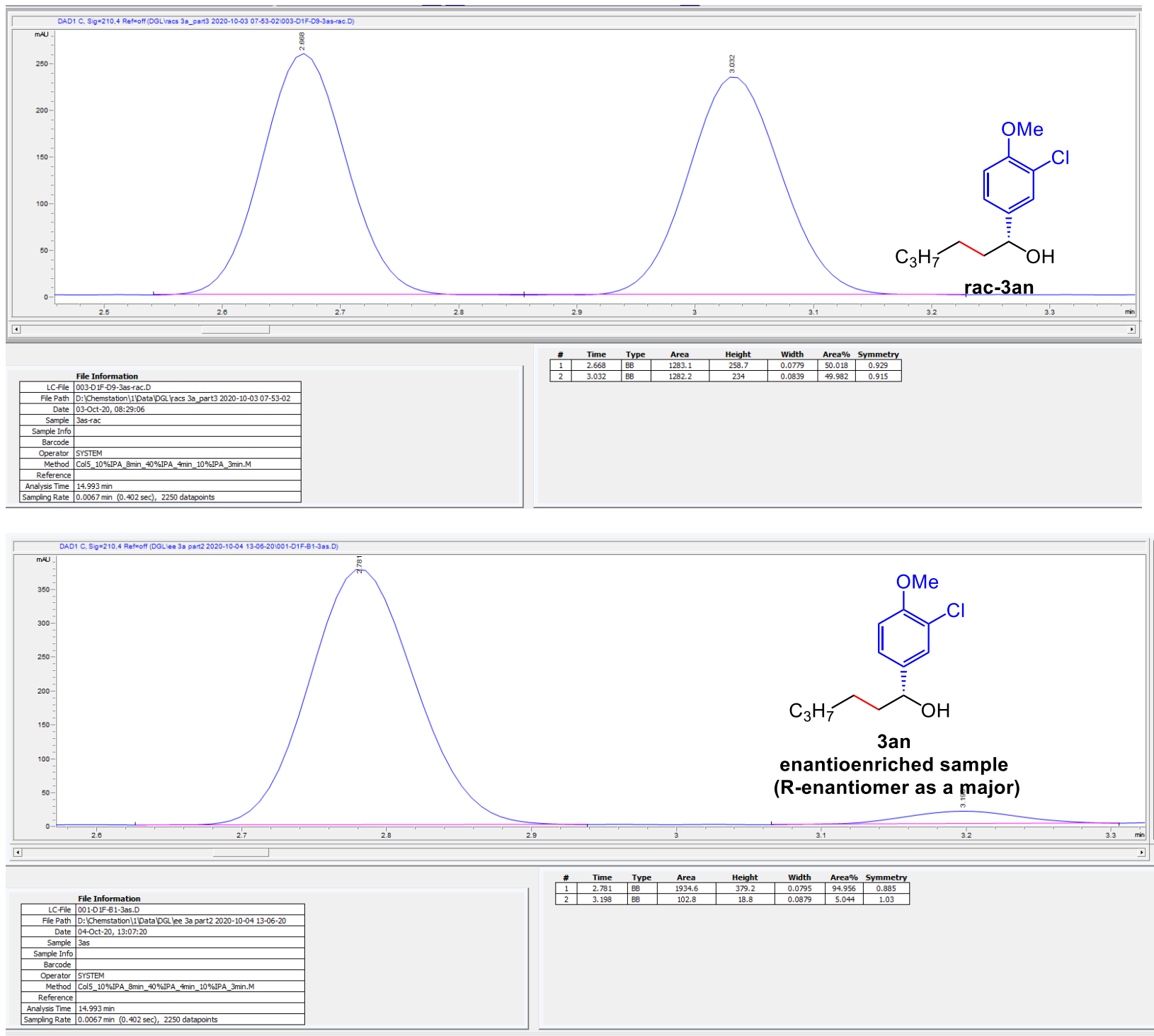
$3 a o$
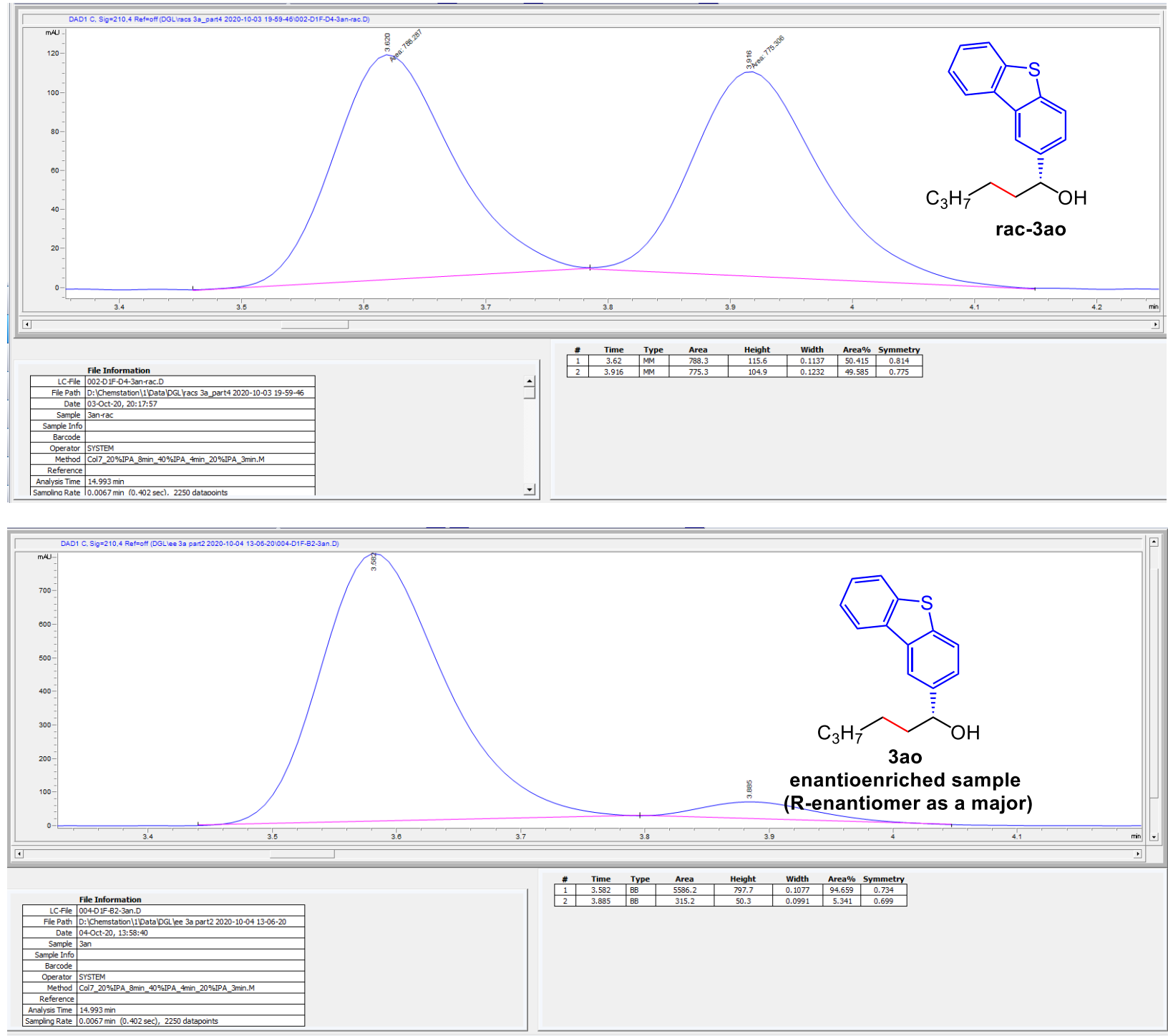
$3 a p$
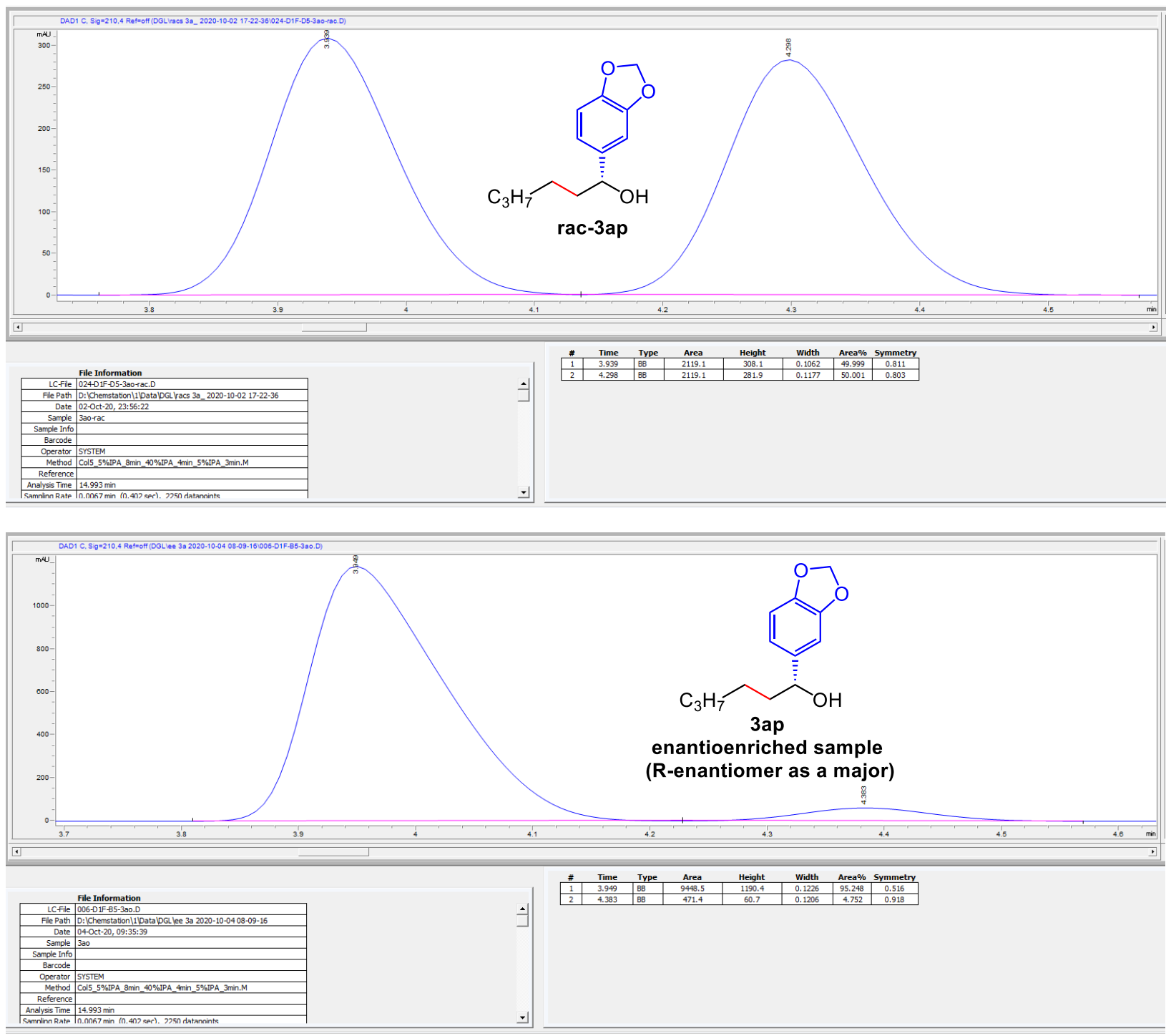
$3 a q$
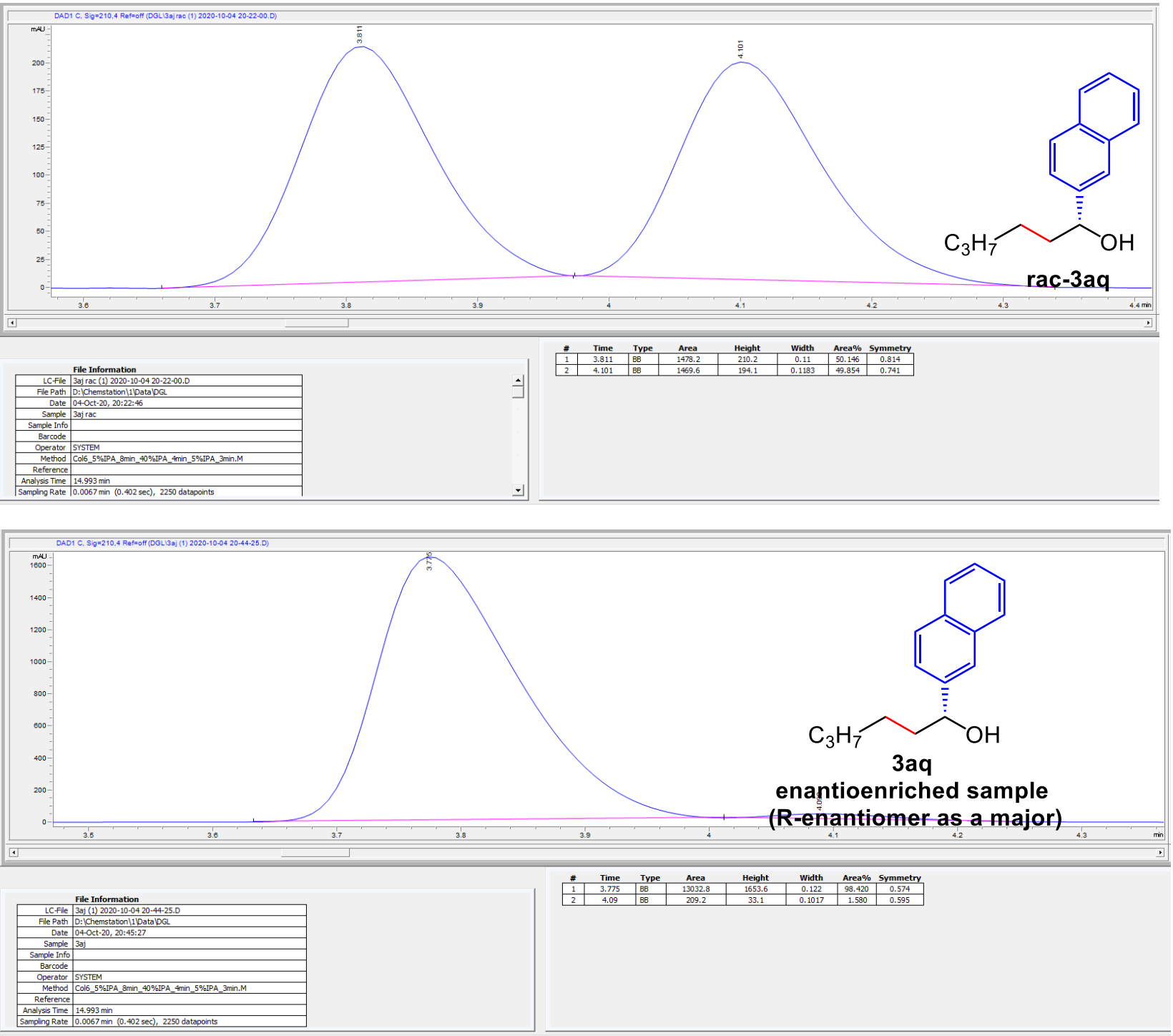
$3 a r$
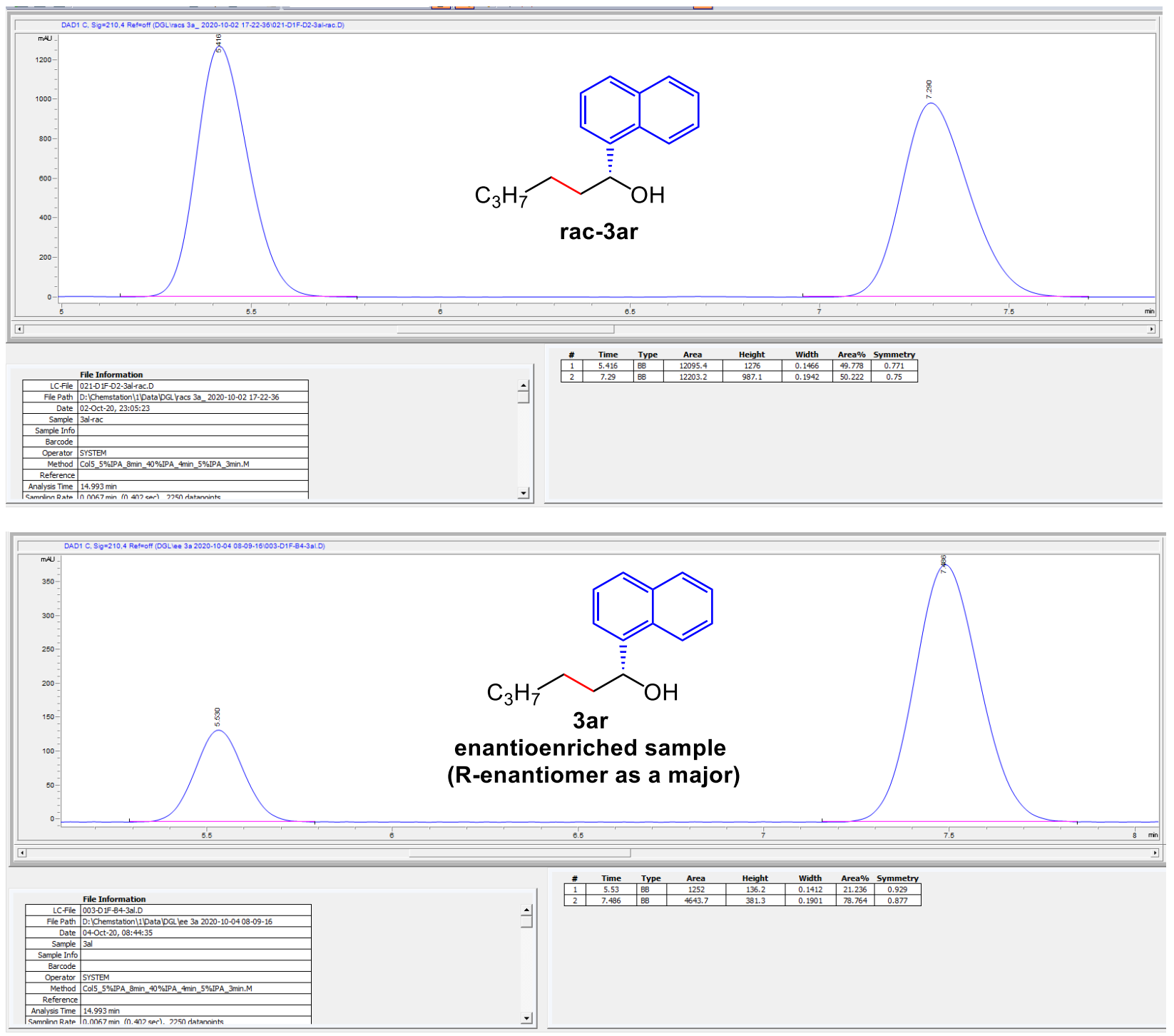
3as
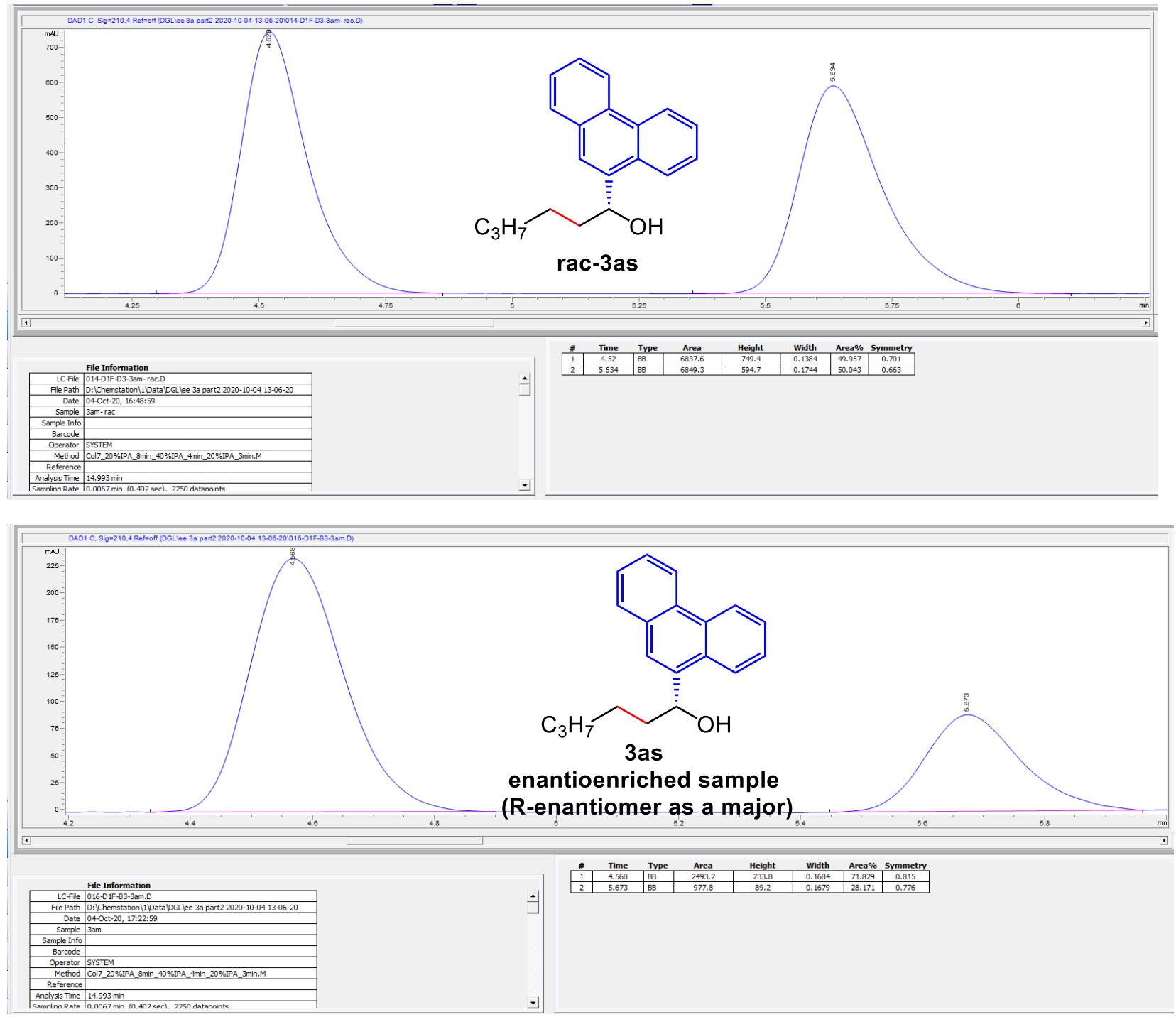
$6 a a$
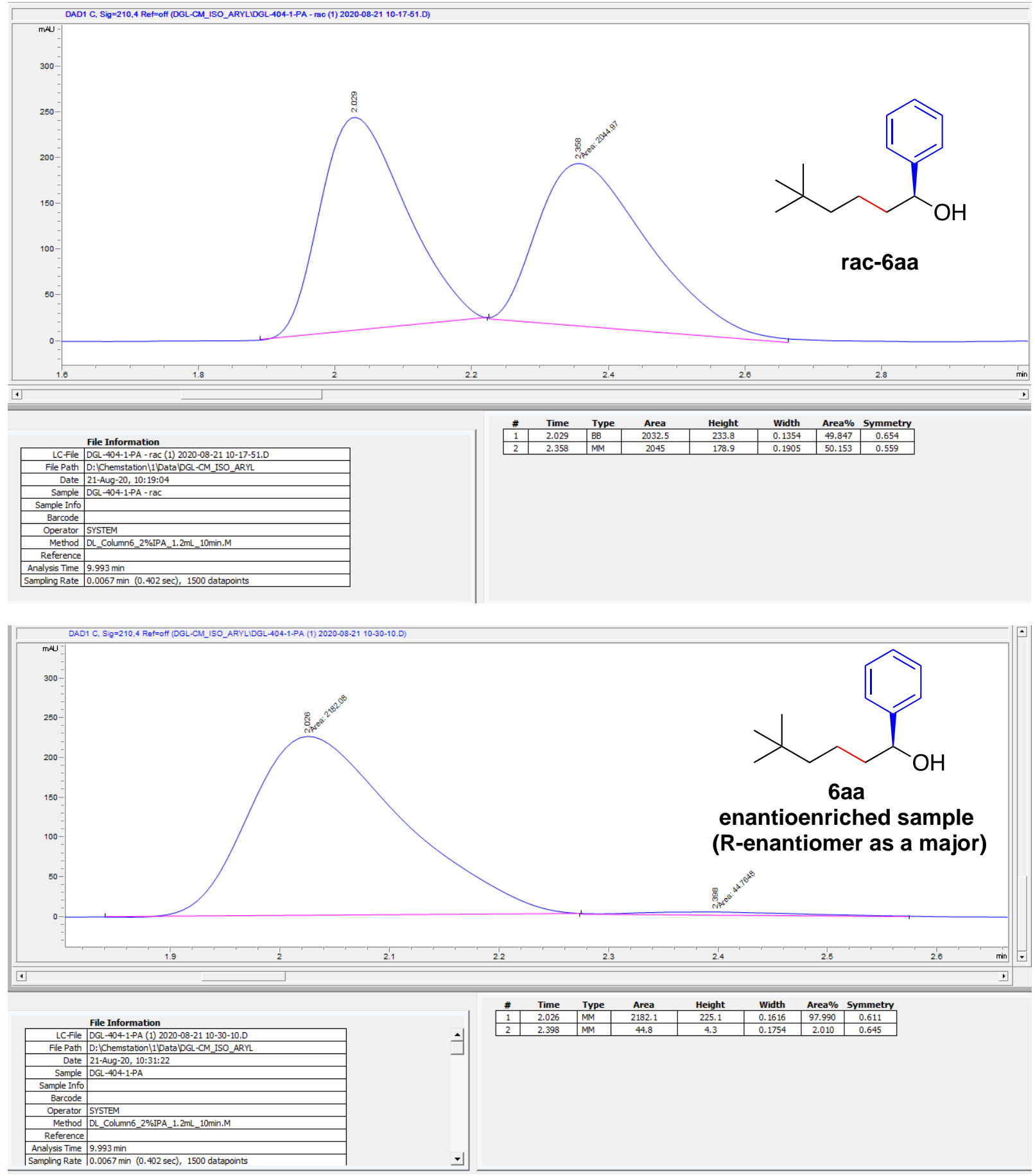


\section{(S)-6aa - $2.44 \mathrm{mmol}$ scale reaction}

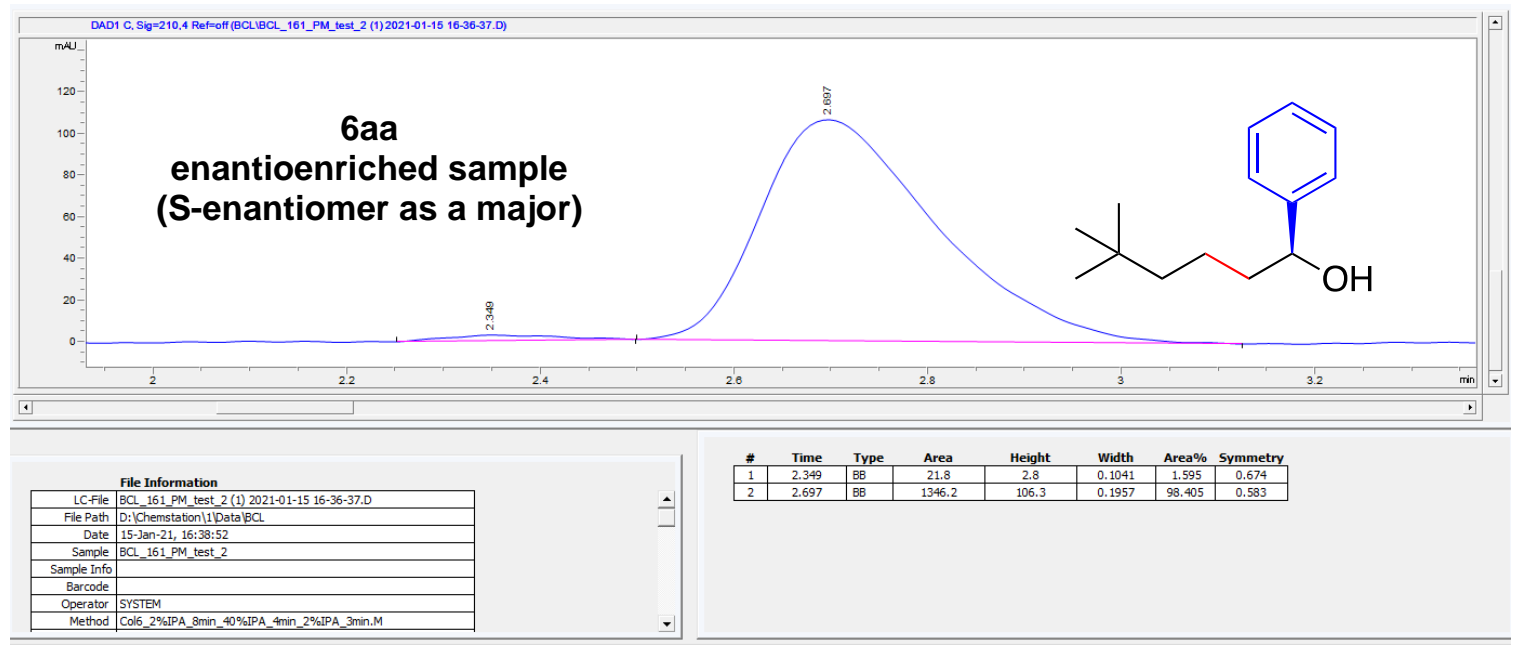

(S)-6aa - prepared in a stepwise fashion

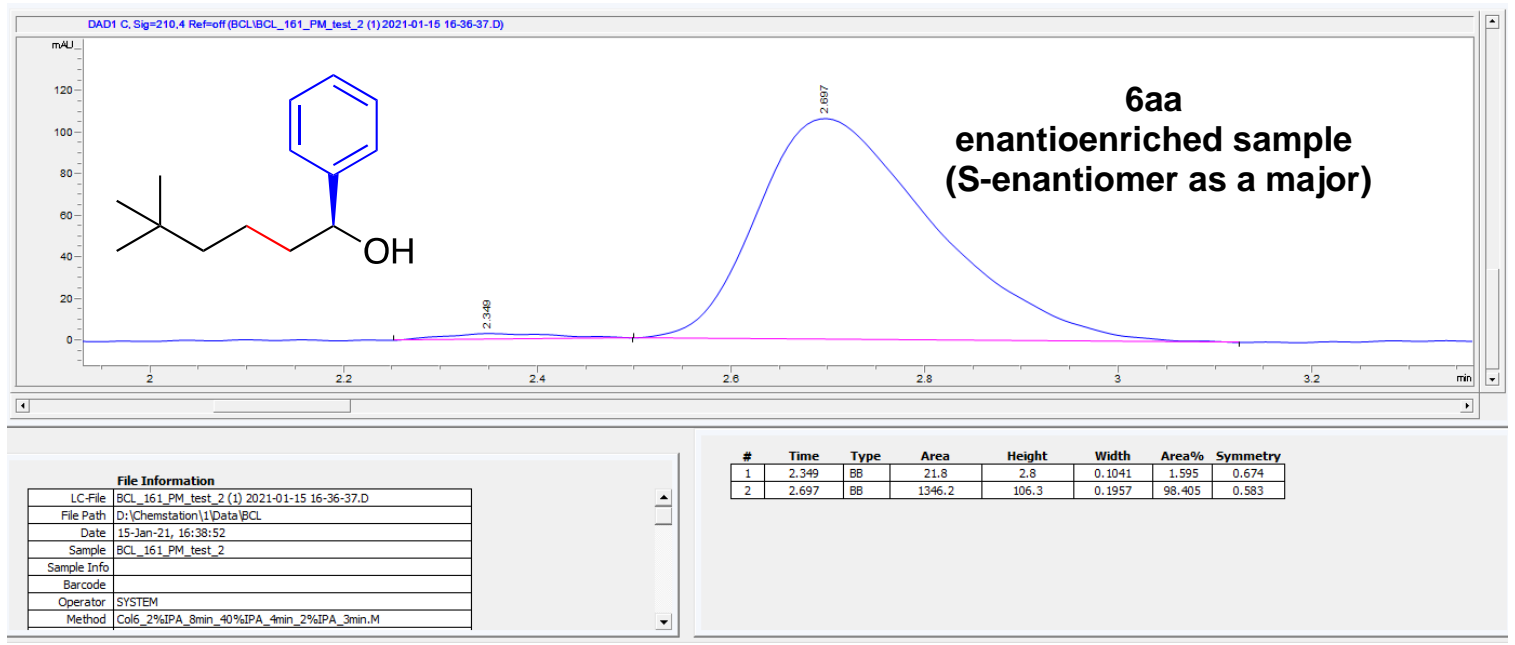


$6 b a$
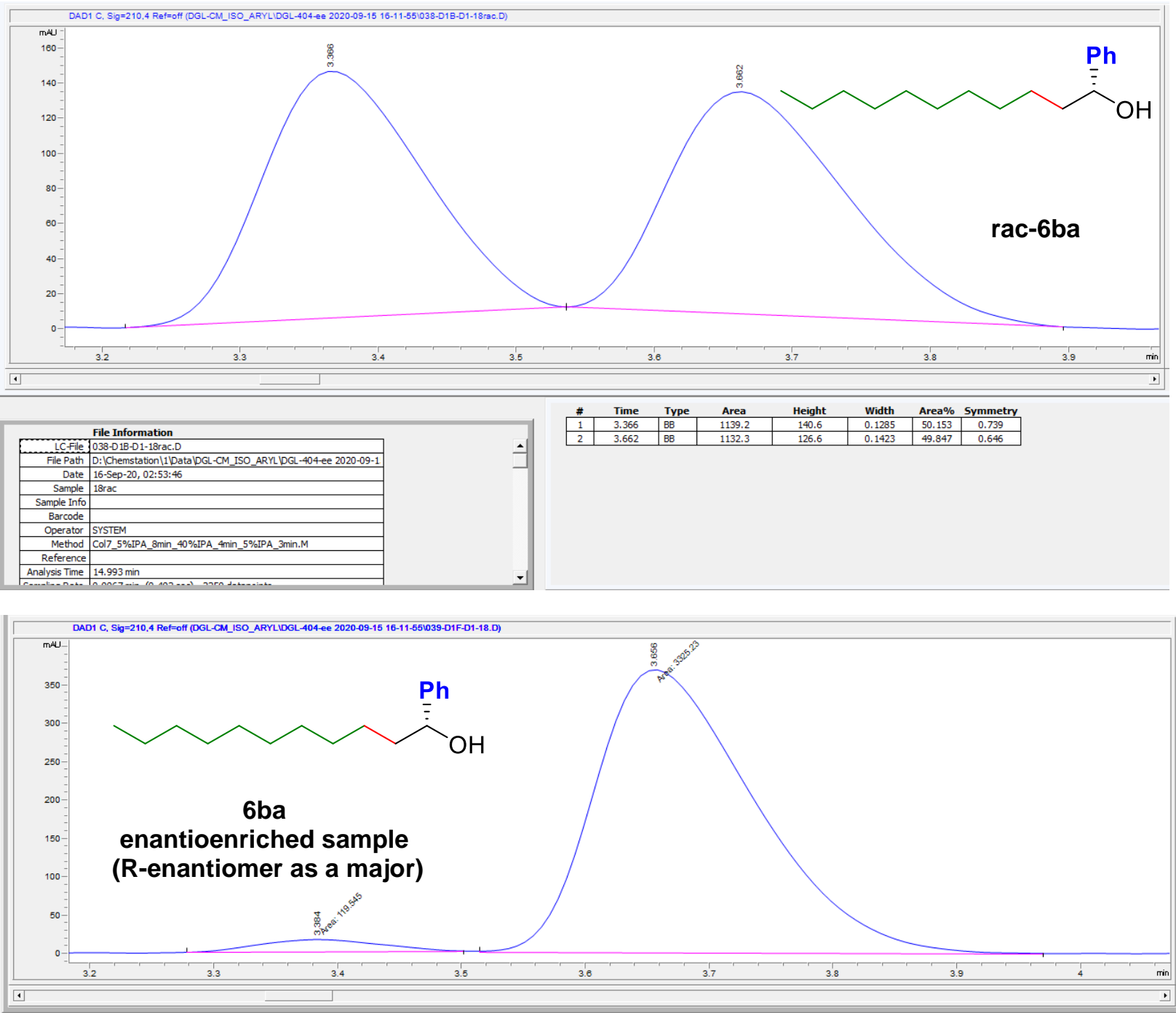

File Information

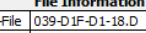

File Path D: IChemstation|1DatalDGL-CM_ISO_ARYLDGL-404ee 2020-09-1 Date 16 -Sep-20, 03:11:10

\begin{tabular}{r|r} 
Sample 18 \\
\hline
\end{tabular}

Barcode

Operator SYSTEM

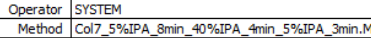

\begin{tabular}{c|c} 
Reference & \\
\hline Analysis Time & $14.993 \mathrm{~min}$
\end{tabular}
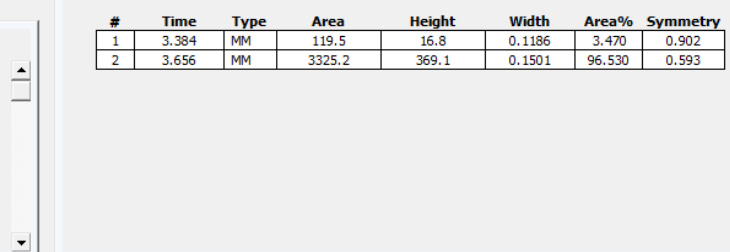
$6 c a$
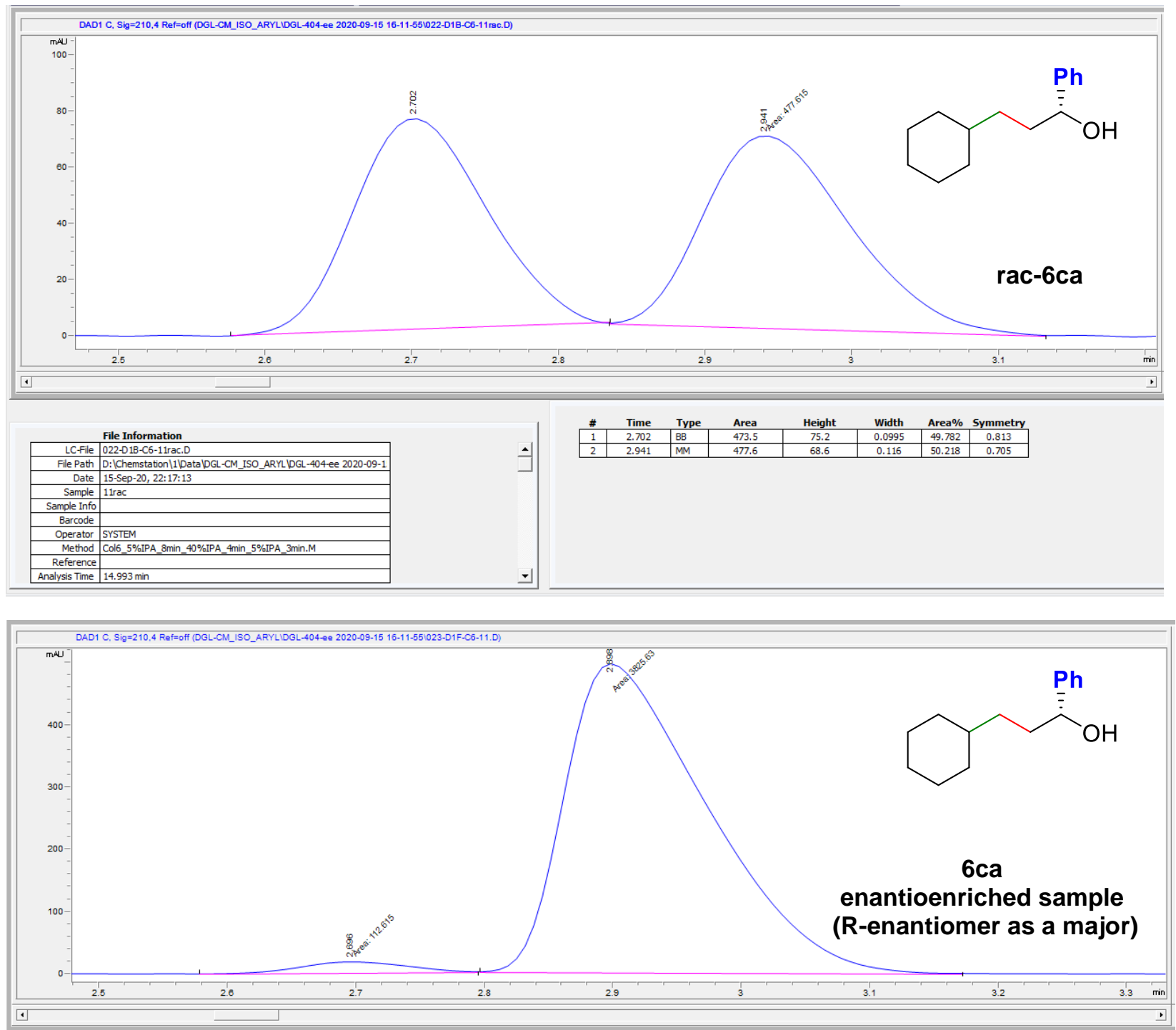

File Information

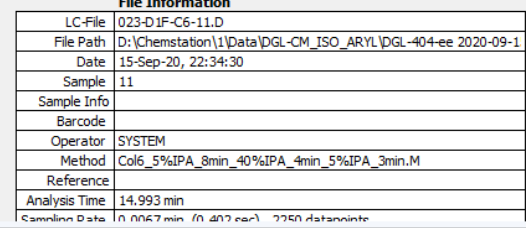

4 
$6 d a$
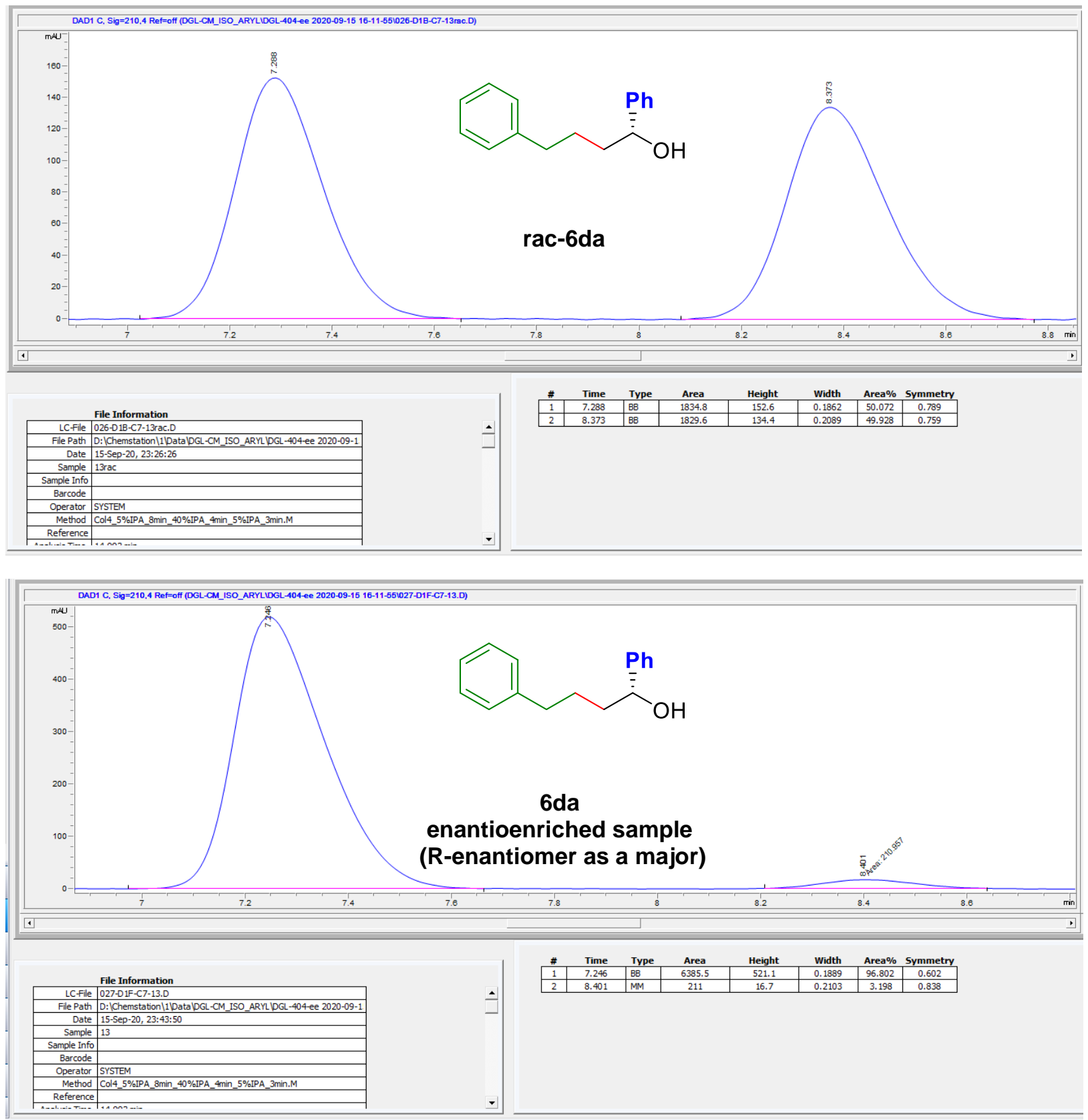
$6 e a$
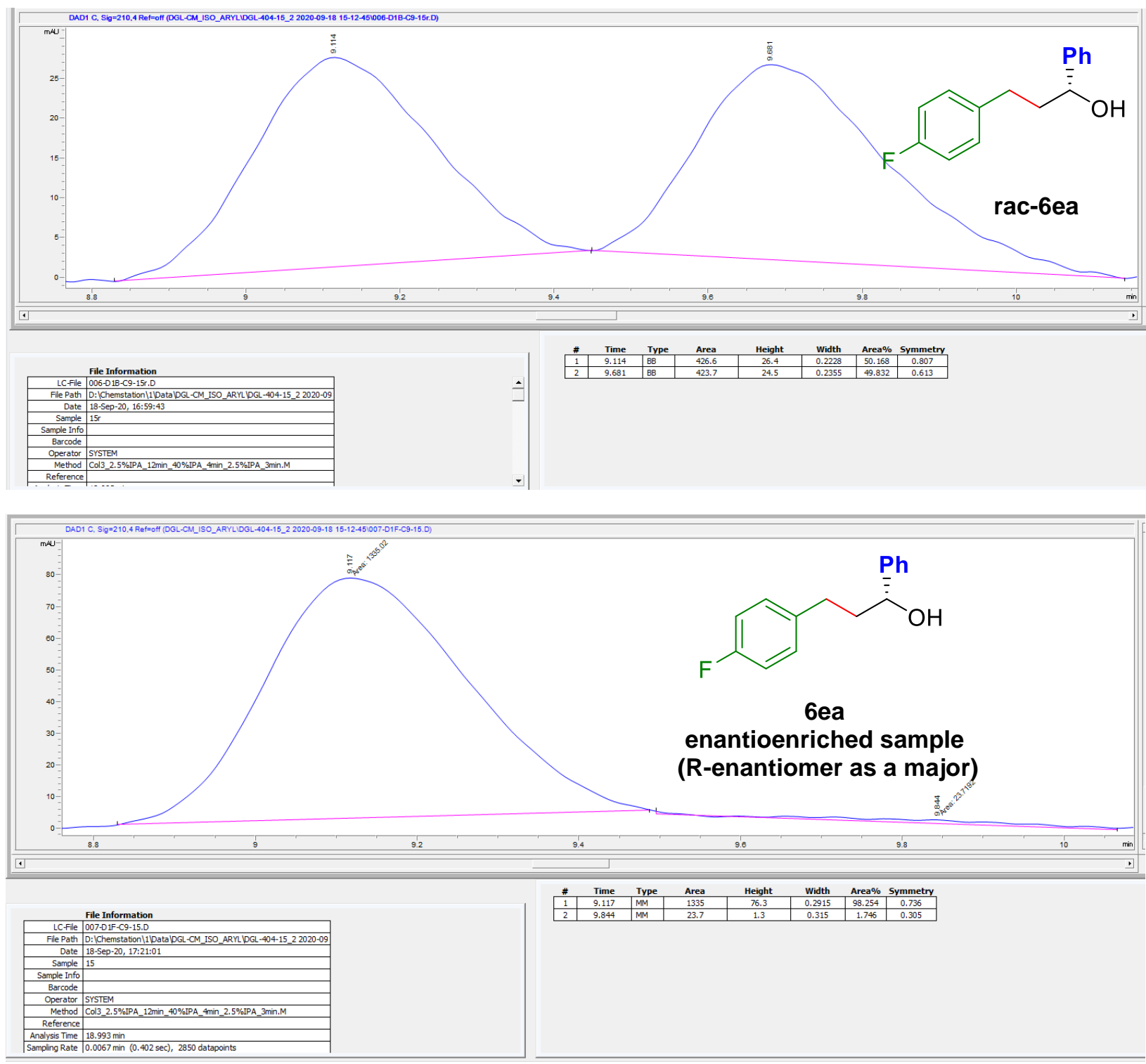
$6 f a$
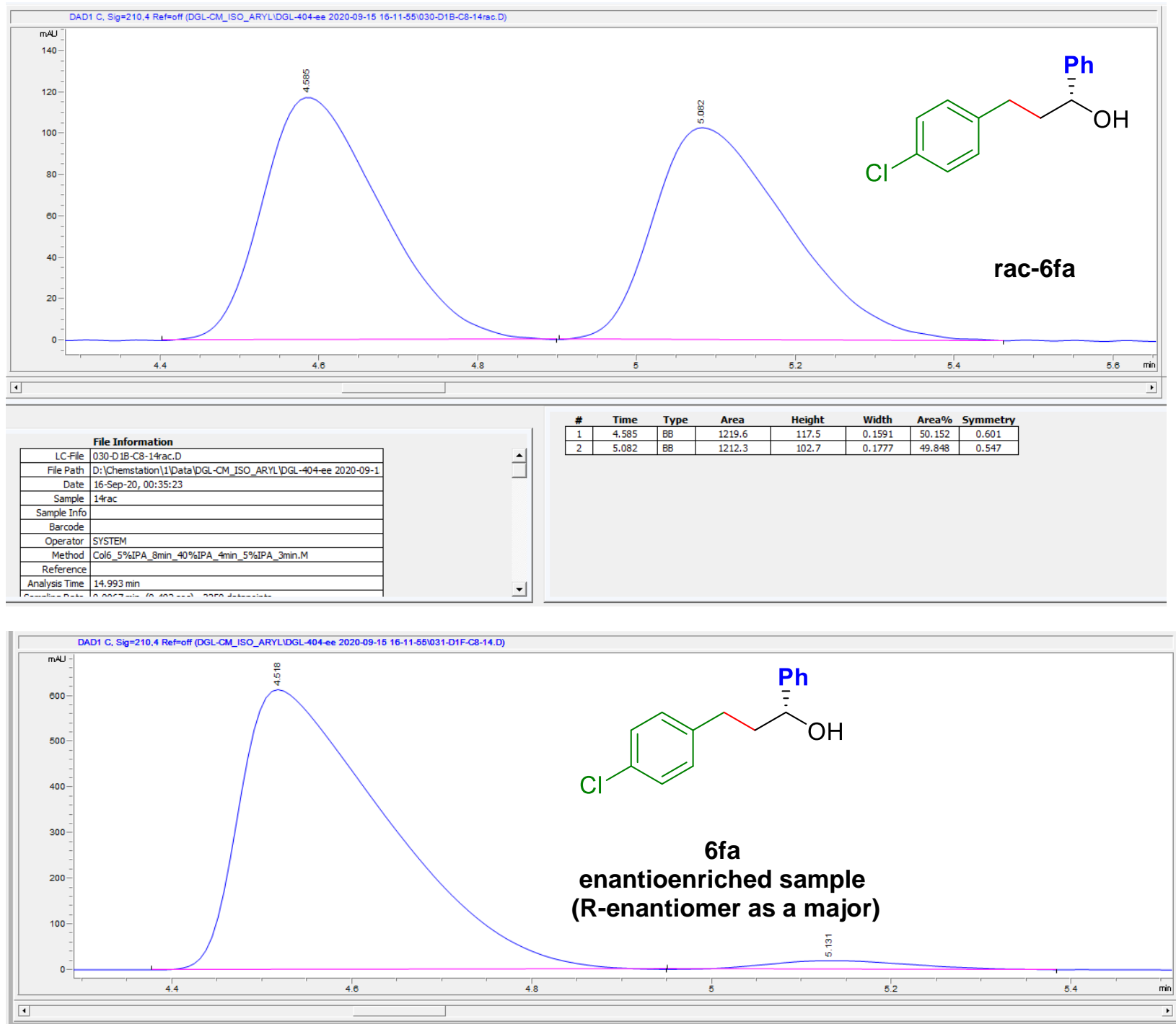

File Information

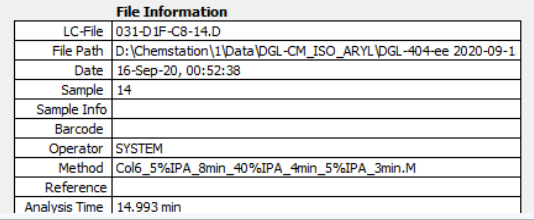

$+$

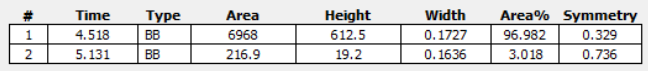




\section{6ga}
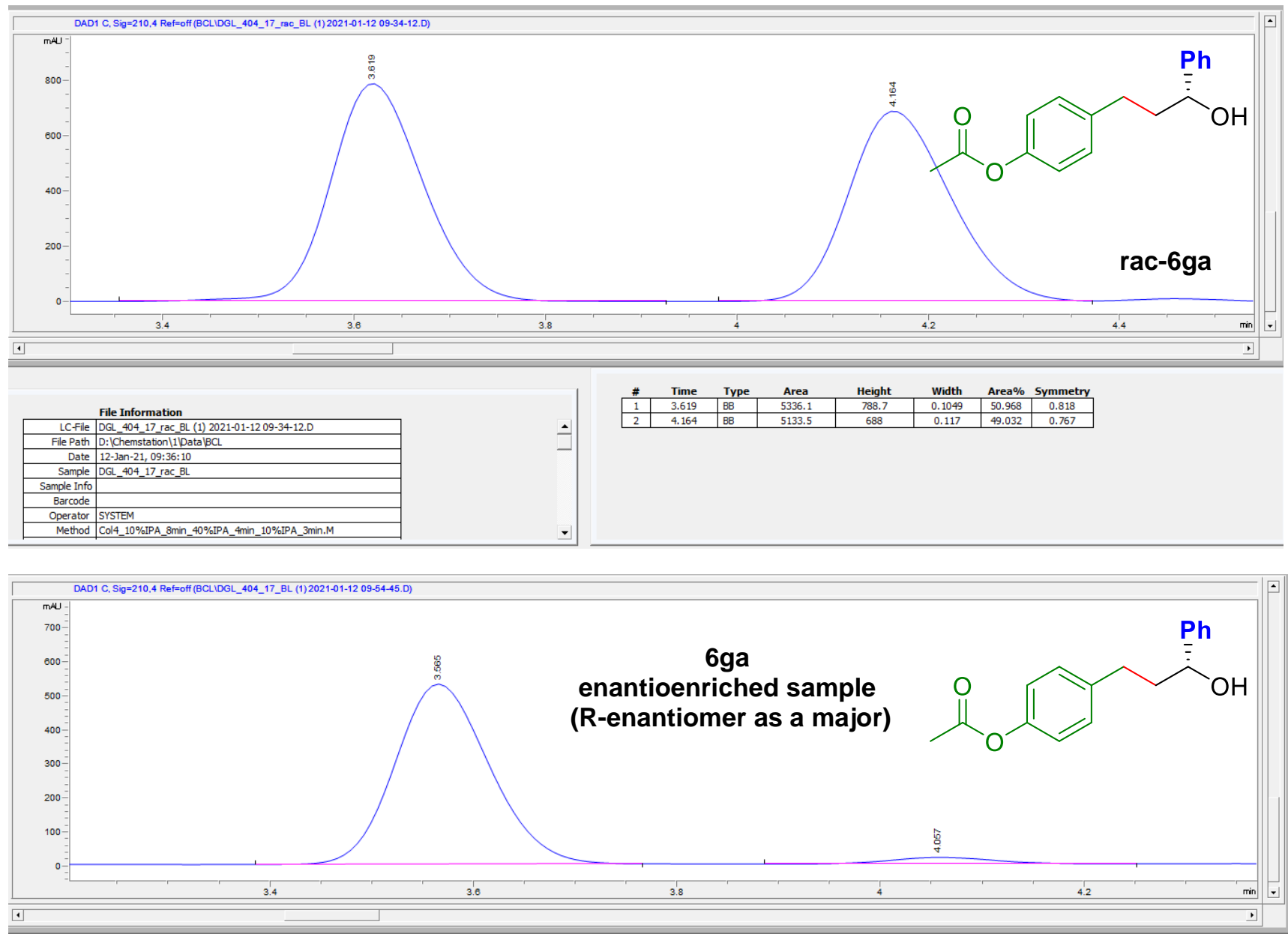

File Information

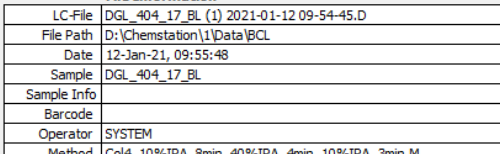

\begin{aligned} Operator & SYSTEM \\ \hline Method & Col4_10\%IPA_8min_40\%IPA_4min_10\%IPA_3min.M \end{aligned}

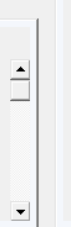


6 ha
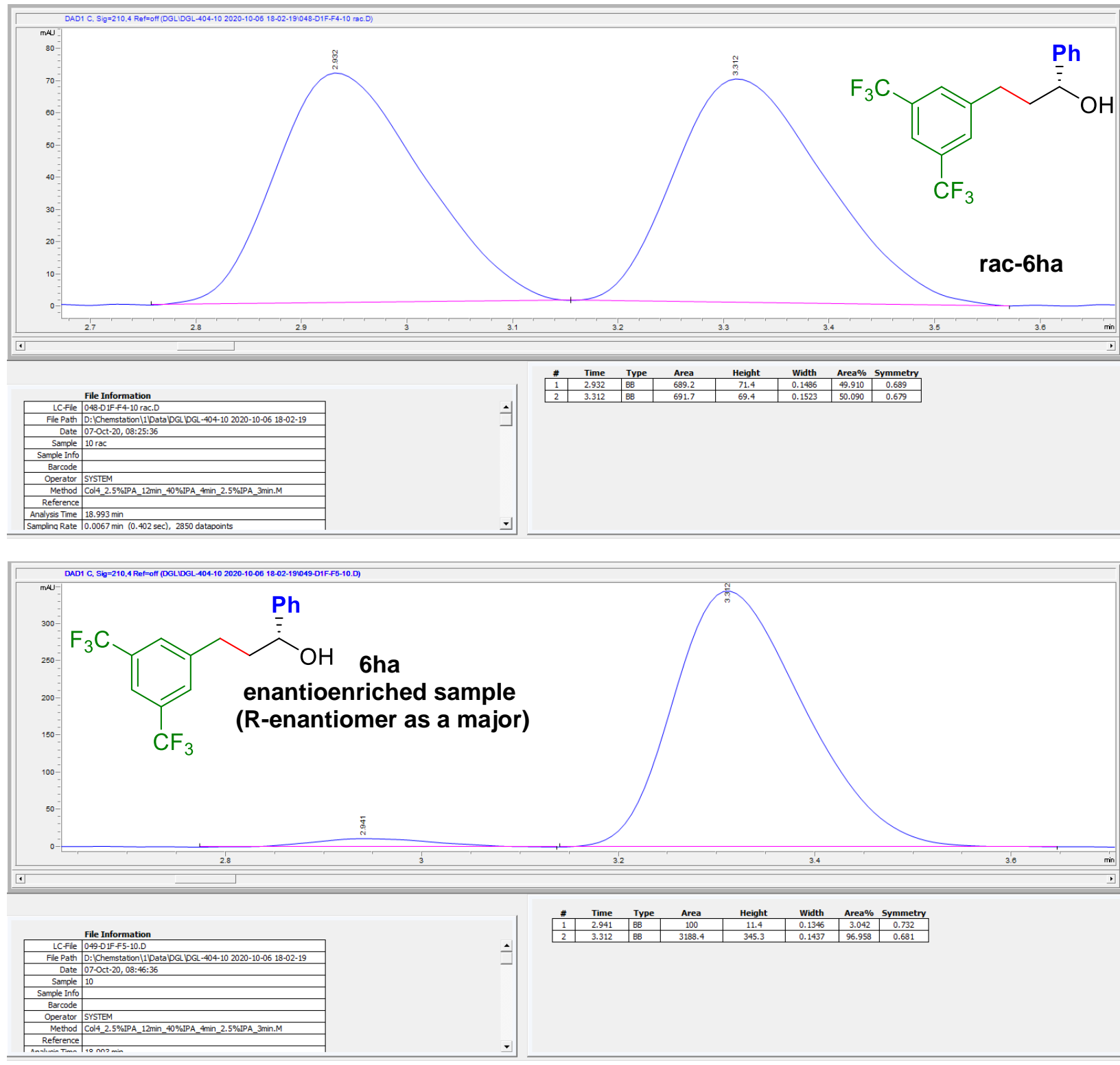
$6 a b$
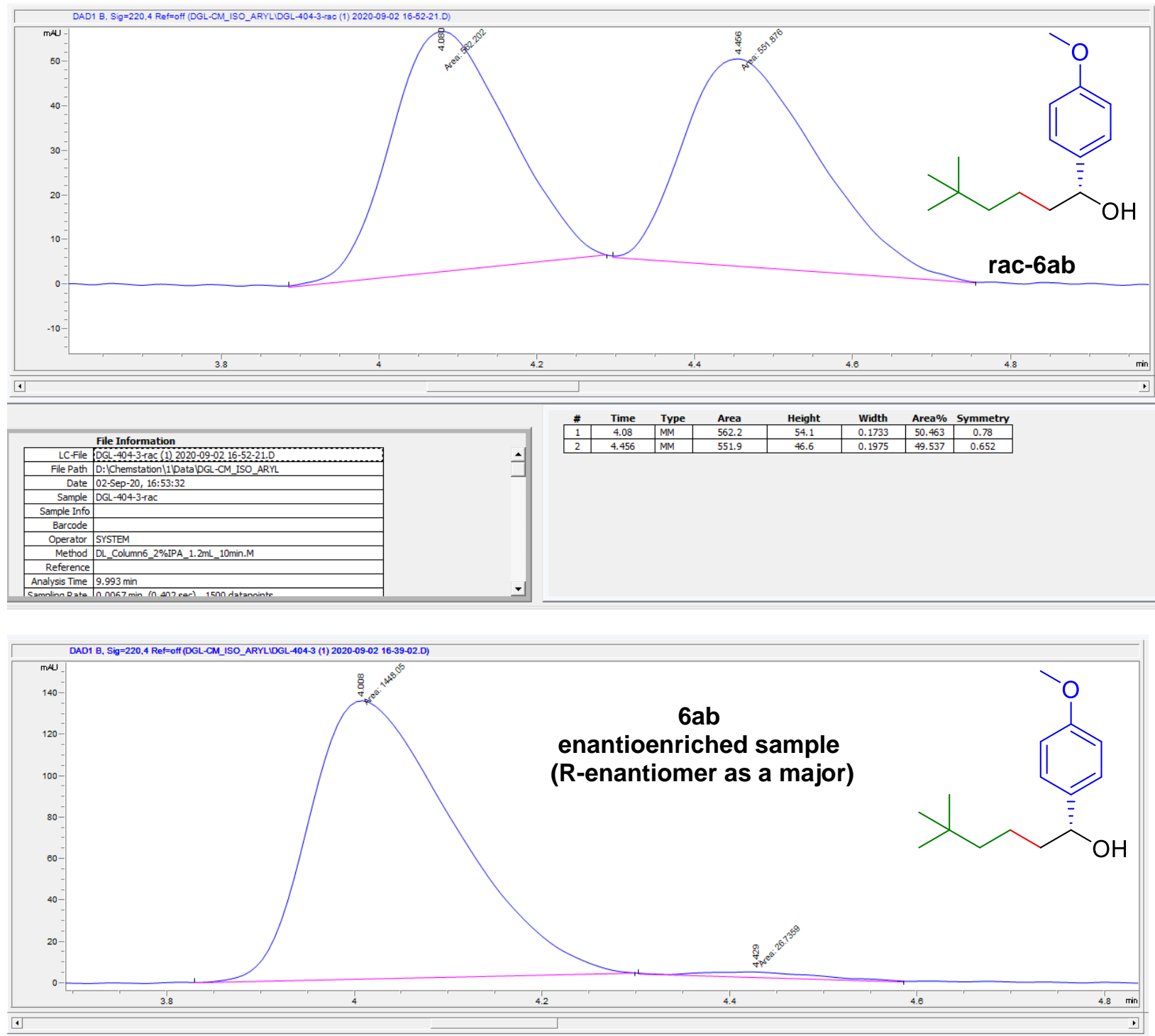

File Information
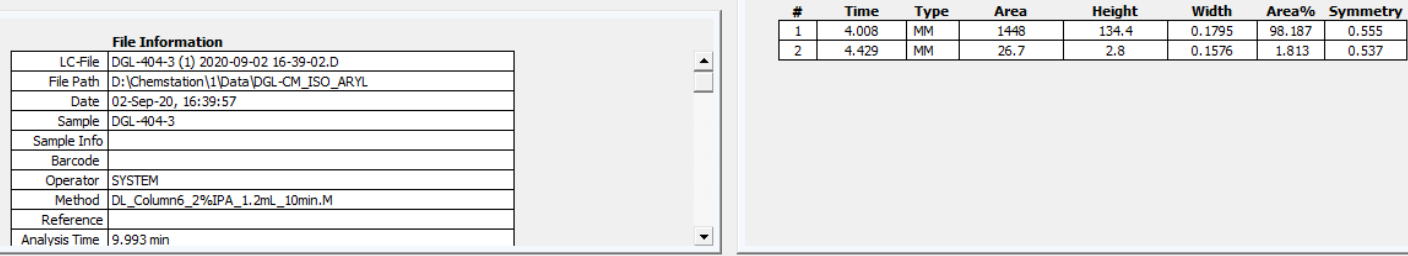
$6 a c$
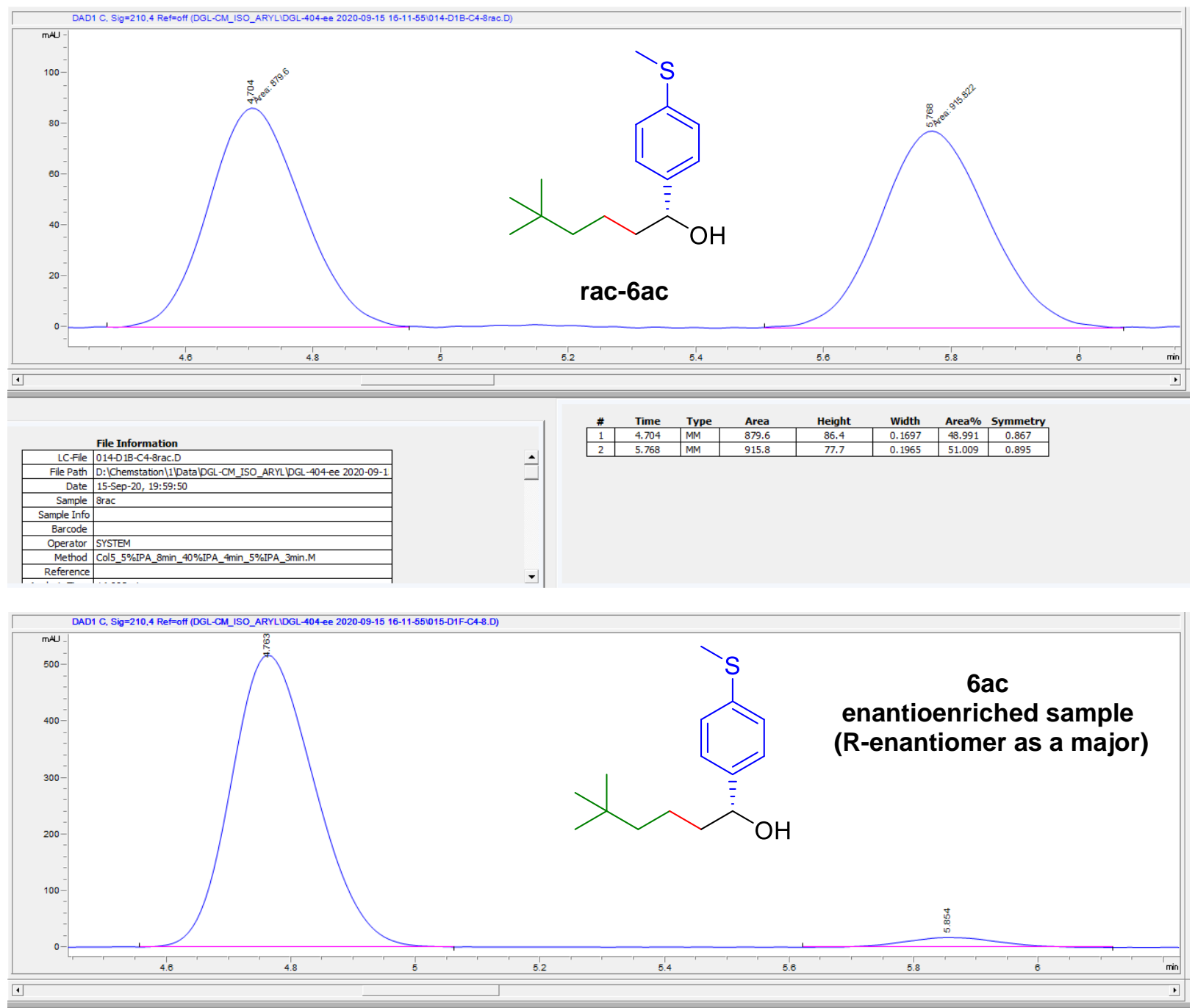

File Information
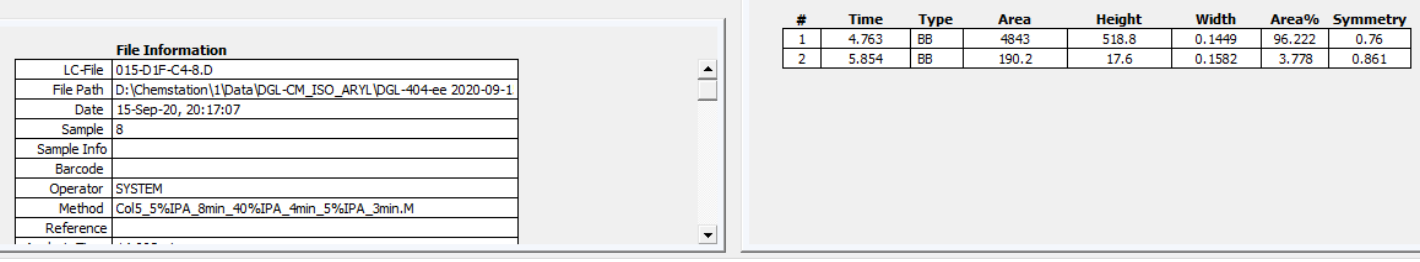
6ad
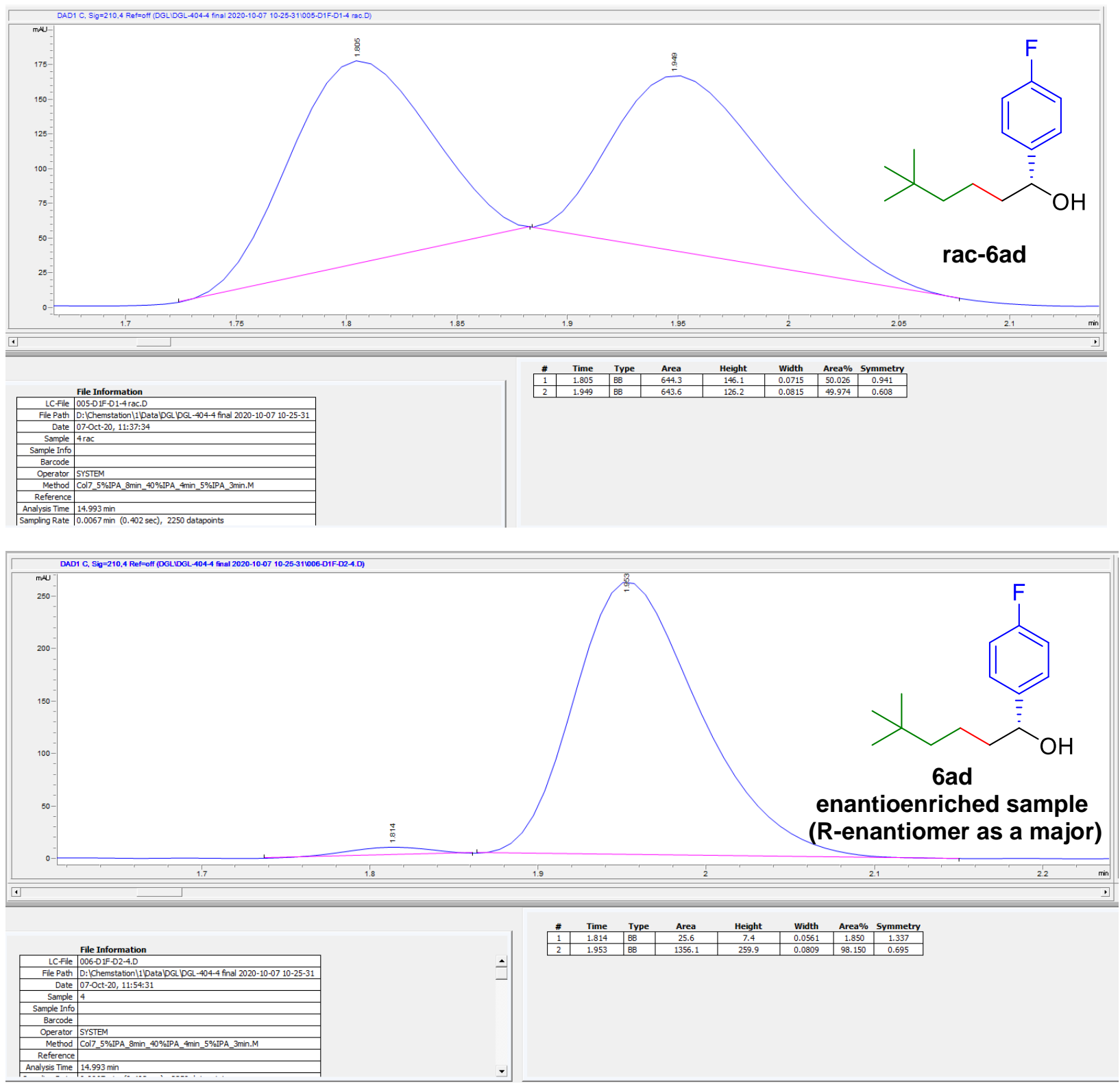
$6 a e$
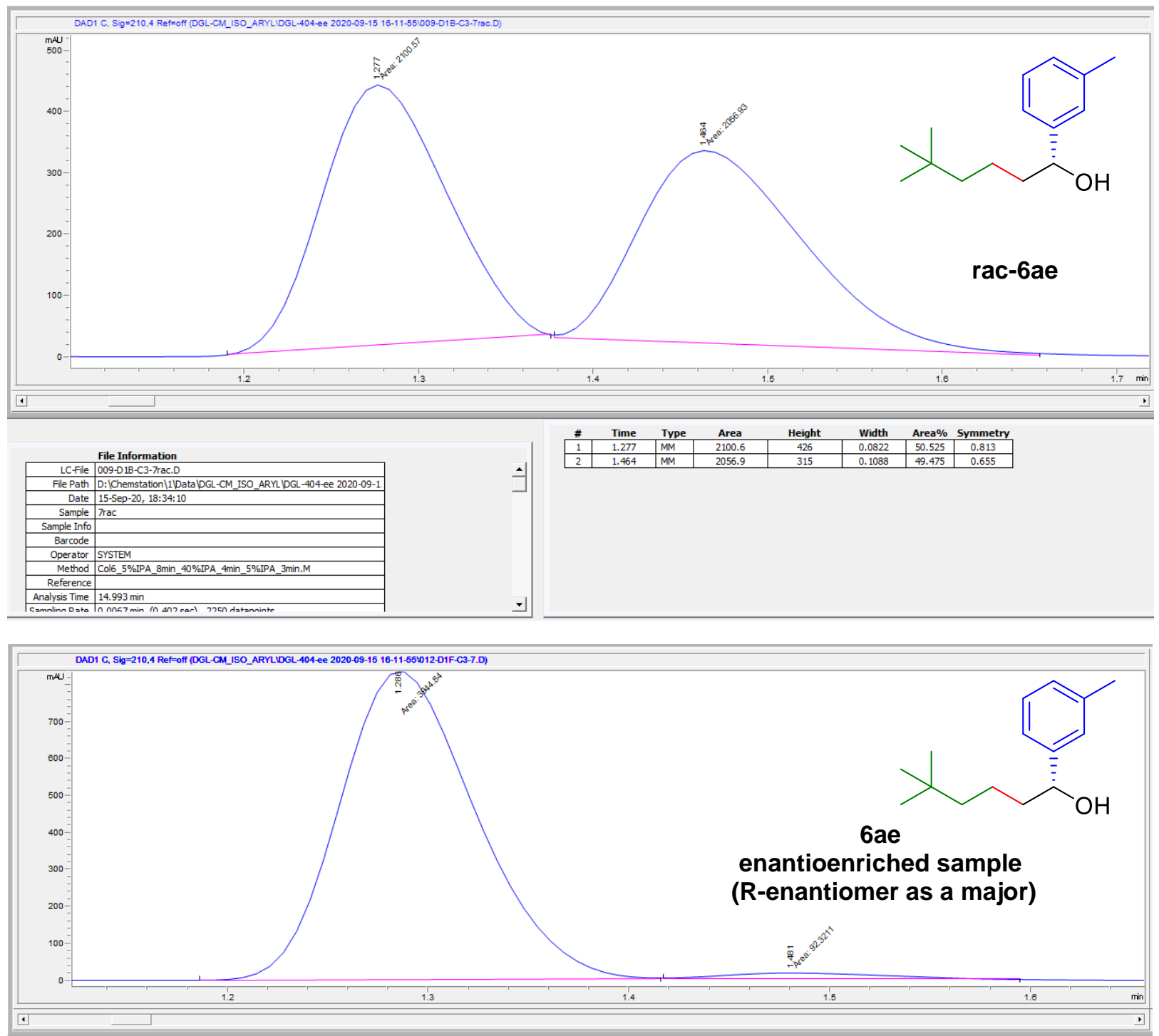

File Information

\begin{tabular}{|c|c|}
\hline LCFile & $012-D 1 F-C 3-7 . D$ \\
\hline File Path & D:|Chemstation|1Data|DGL-CM_ISO_ARYLDGL-404-ee 2020-09 \\
\hline Date & 15 -Sep-20, 19:25:25 \\
\hline Sample & 7 \\
\hline Sample Info & \\
\hline Barcode & \\
\hline Operator & SYSTEM \\
\hline Method & Col6_5\%:IPA_8min_40\%:IPA_4min_5\%.IPA_3min.M \\
\hline Reference & \\
\hline
\end{tabular}

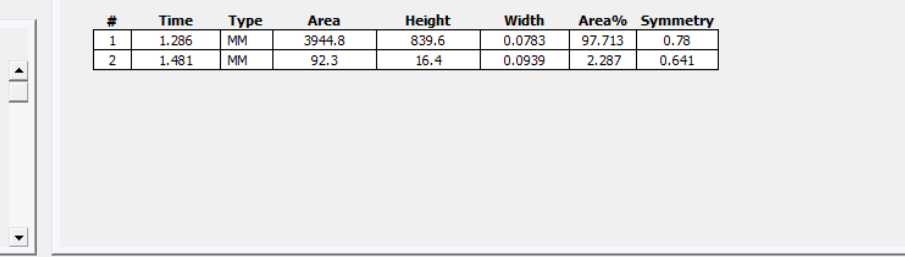


6af
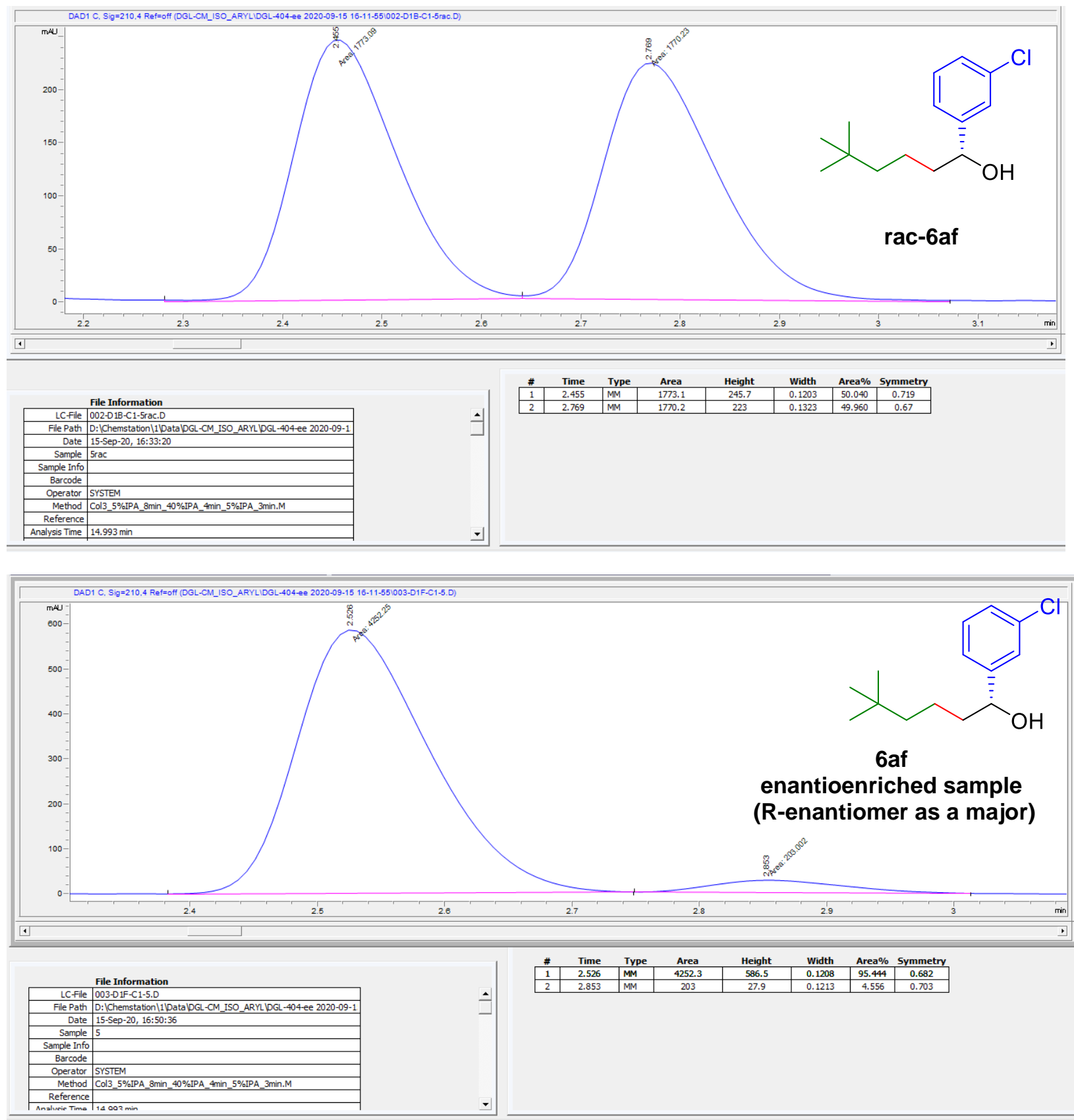
6ag
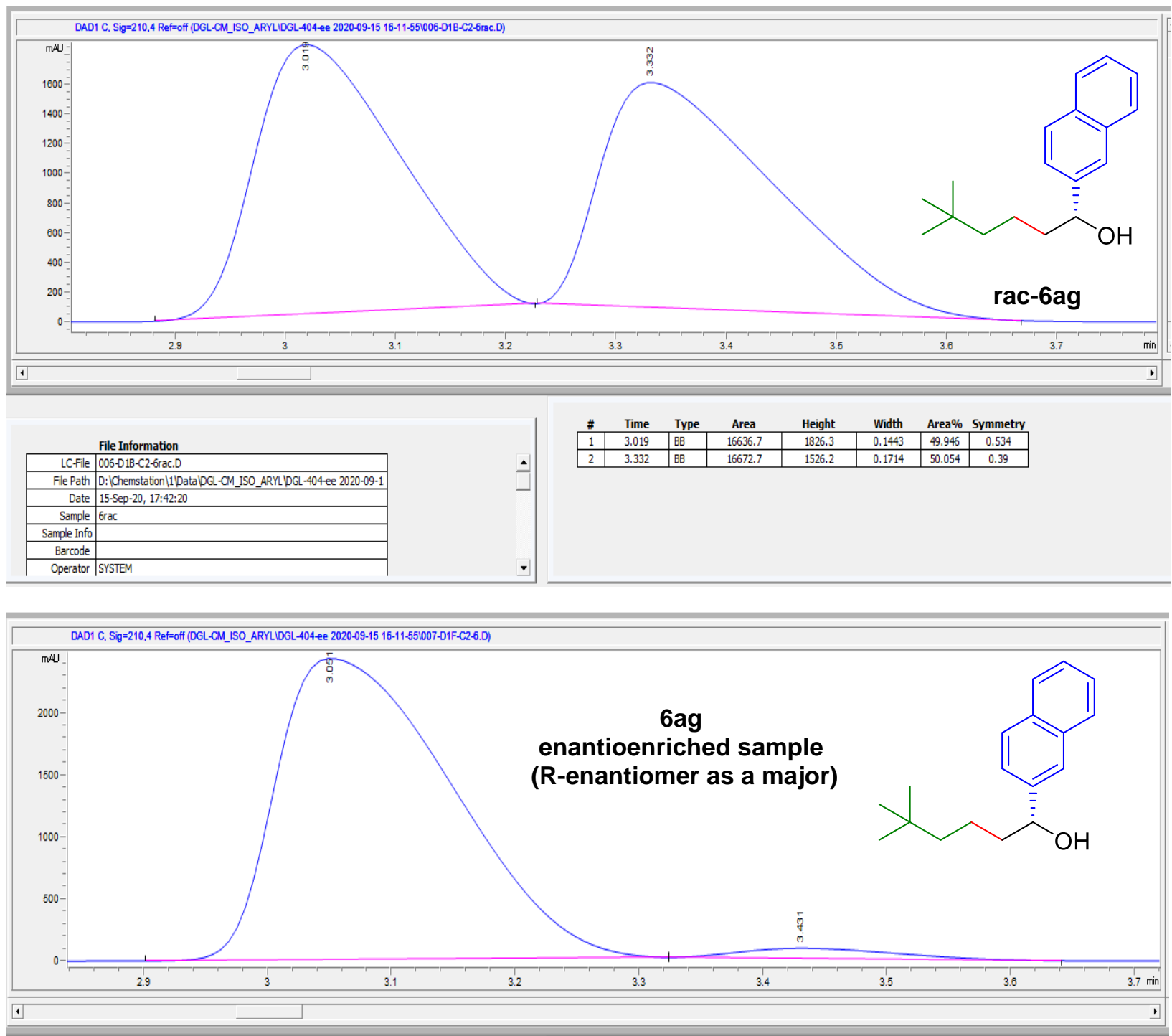

File Information

File Path D: IChemstation 1 1 Data DGL-CM ISO ARYL DGL-404-ee 2020-09-1

Date 15 -Sep-20, 17:59:44

Sample 6

Sample Info

Barcode

Operator SYSTEM

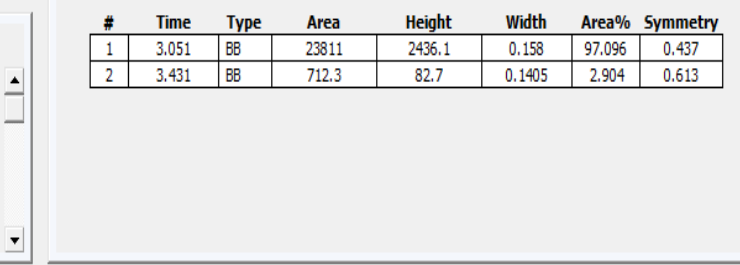




\section{$9 a a$}
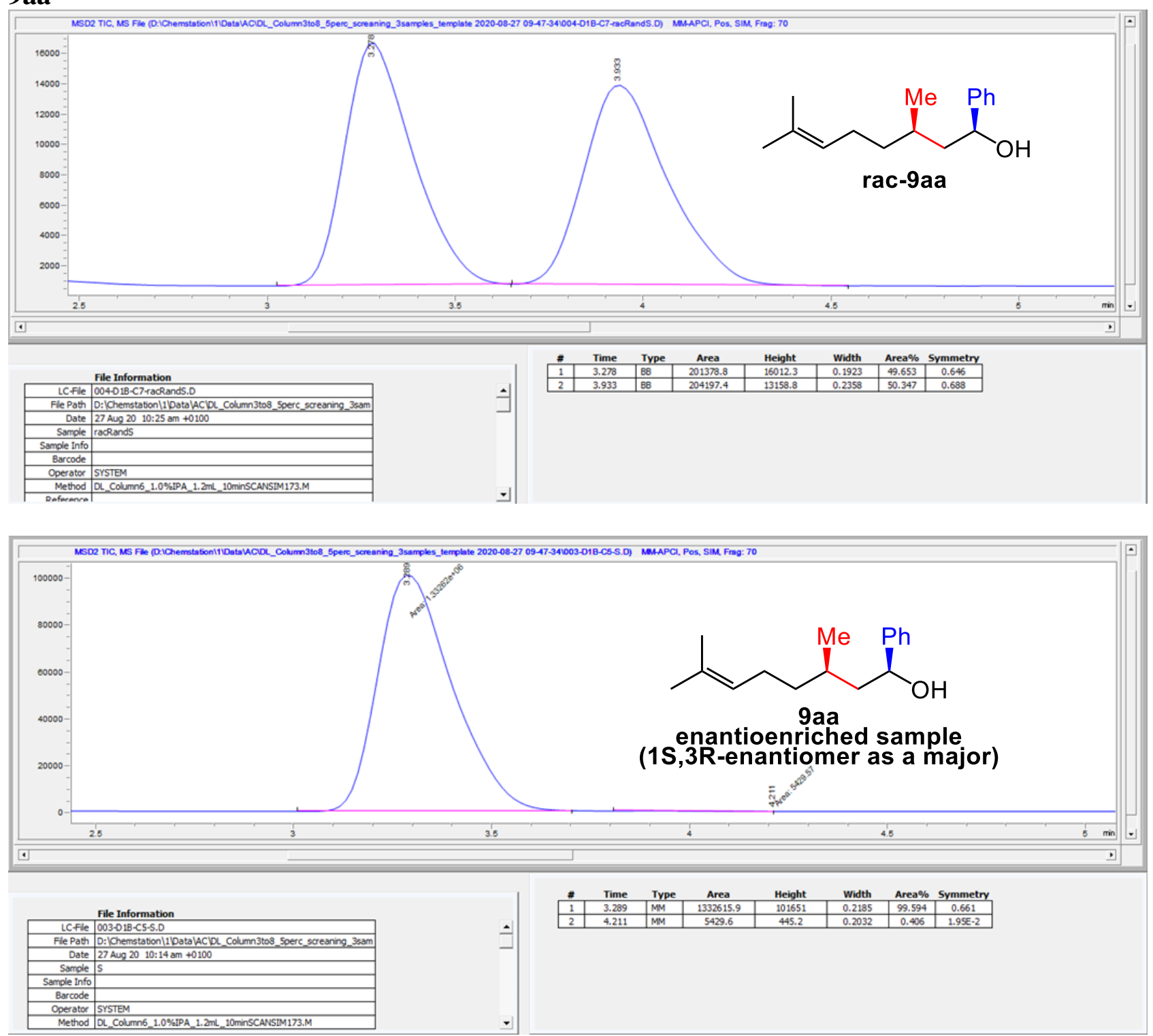
9aa'
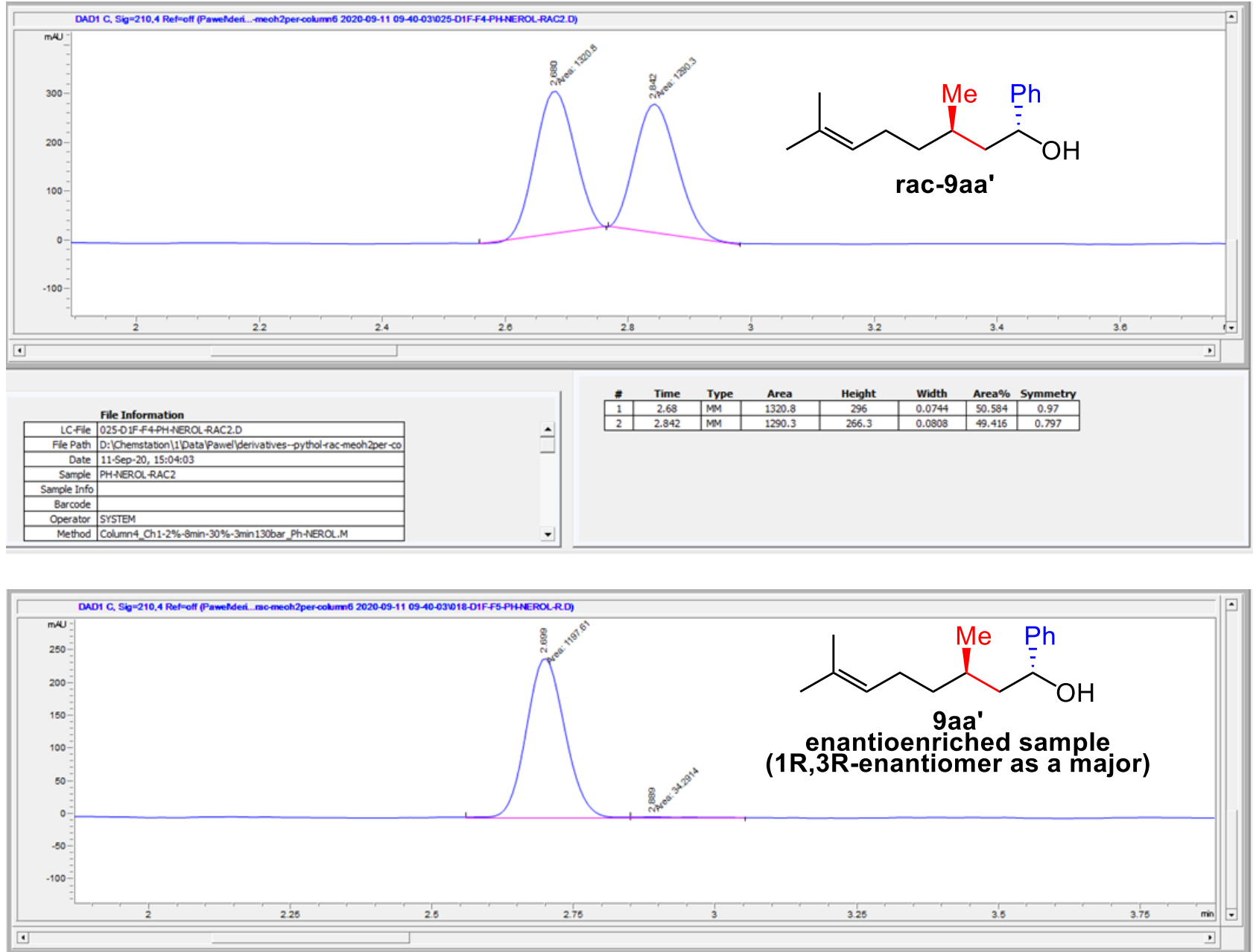

File Information
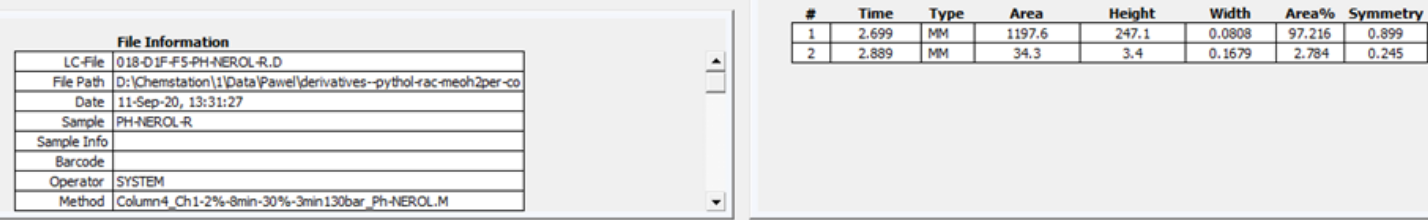
9ba'
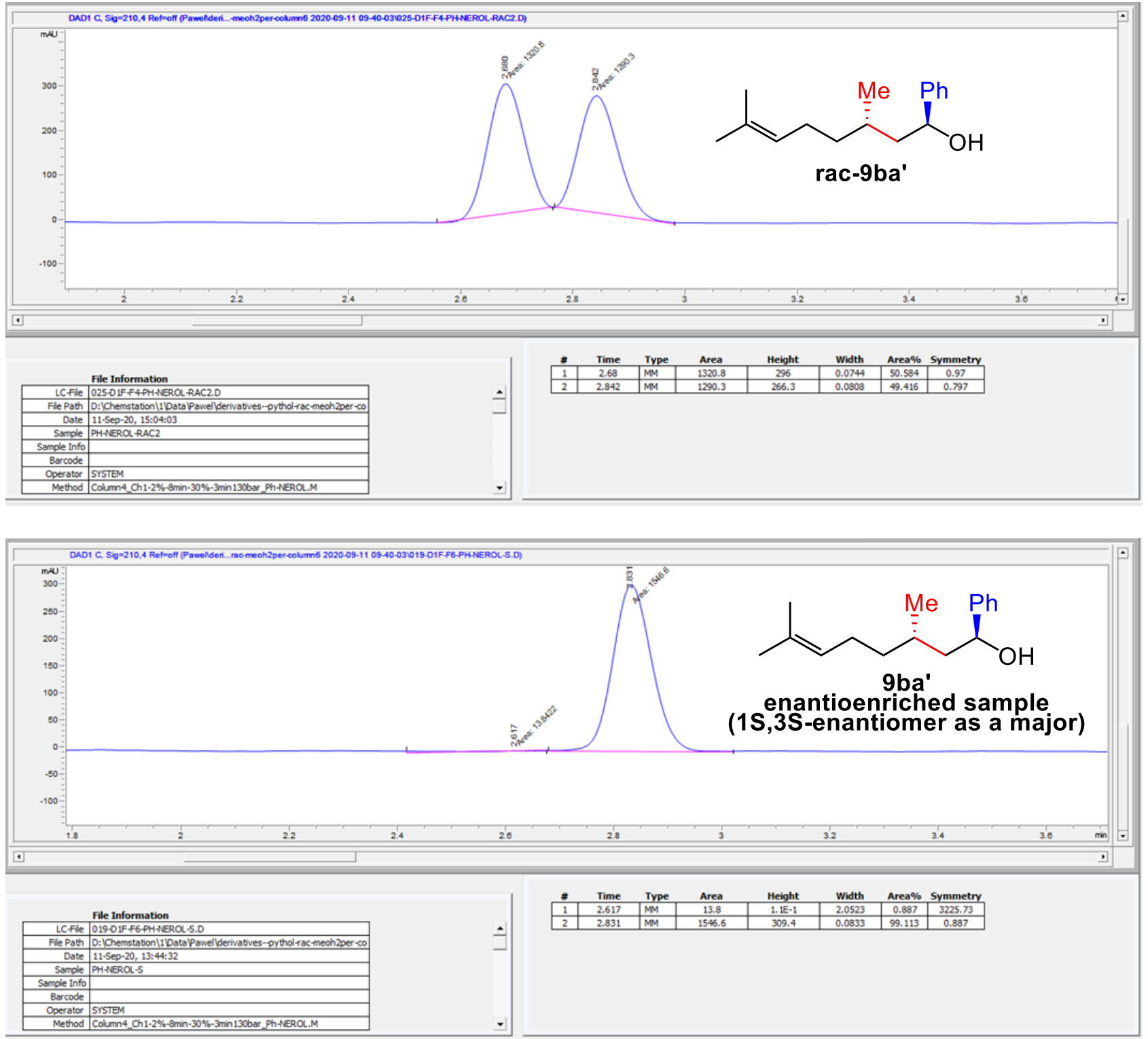

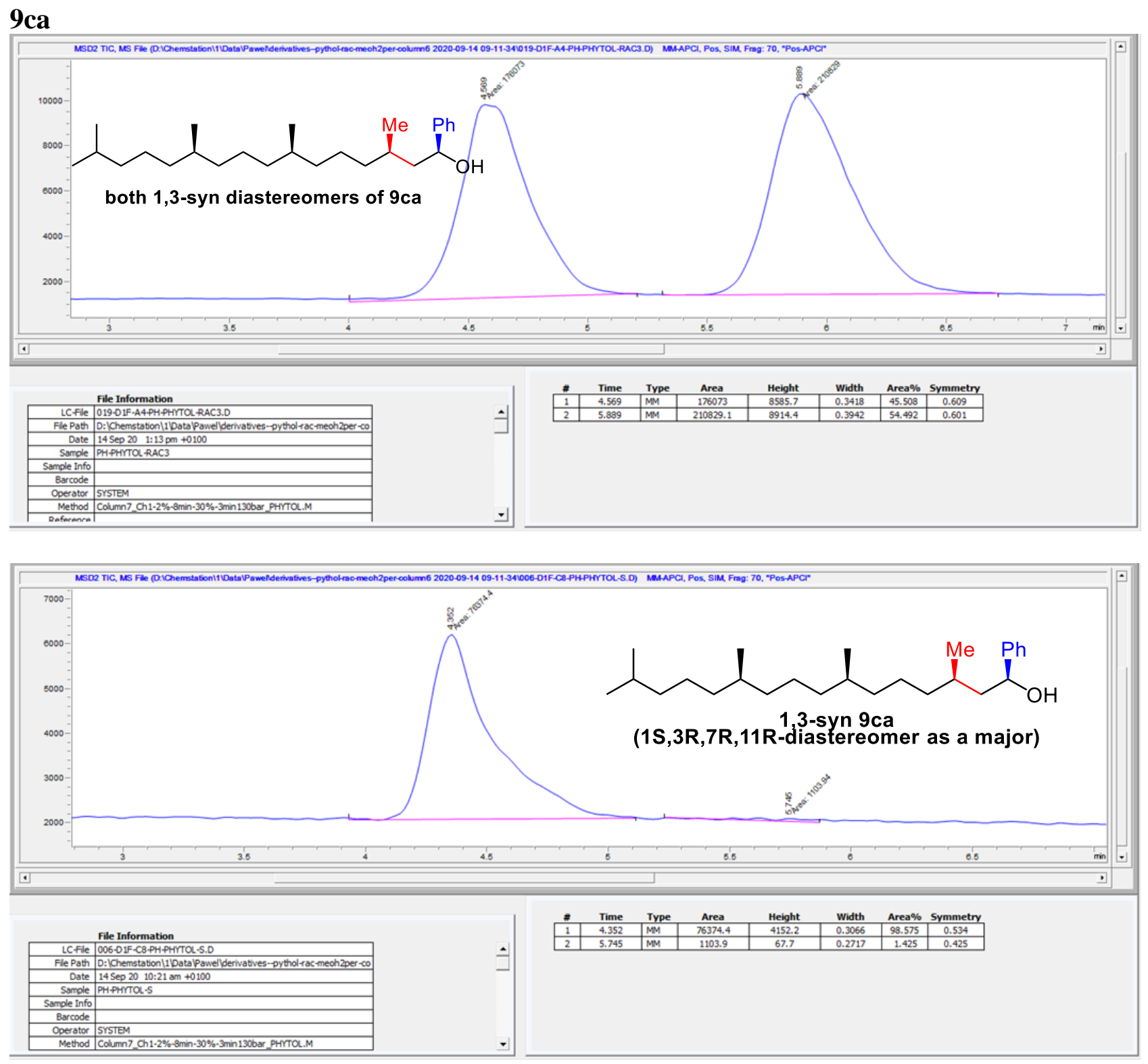


\section{9cb}
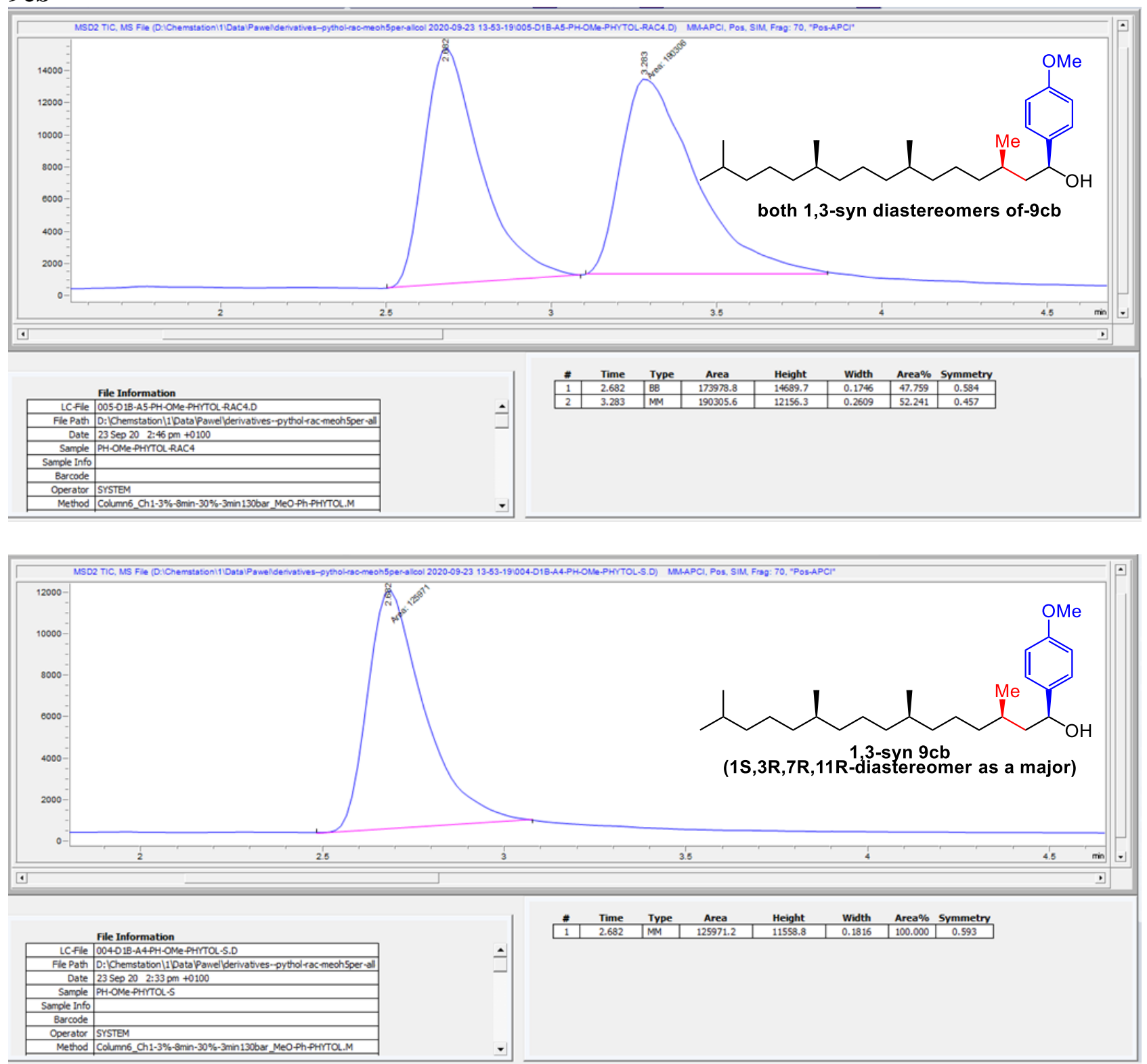

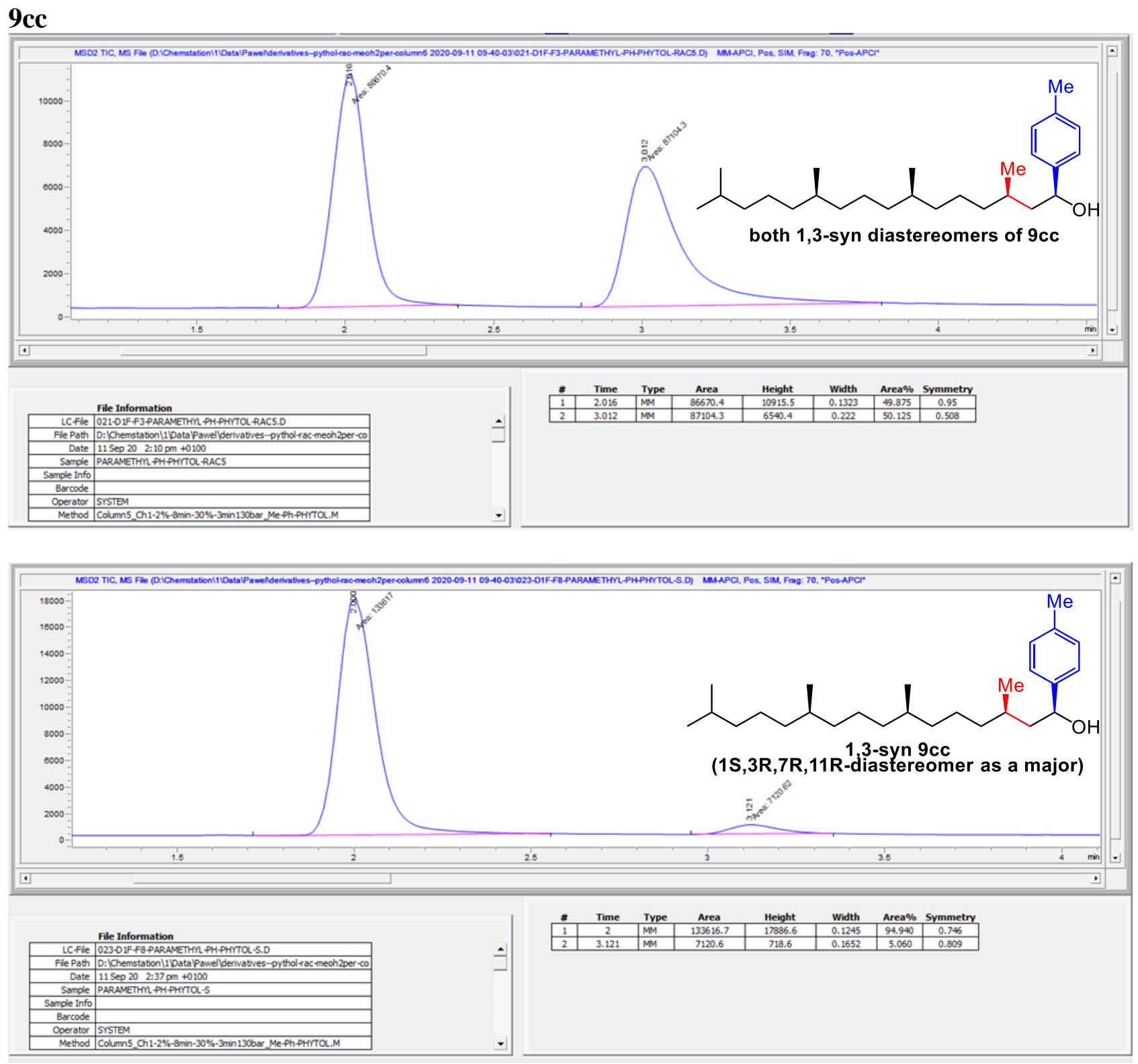


\section{9cd}
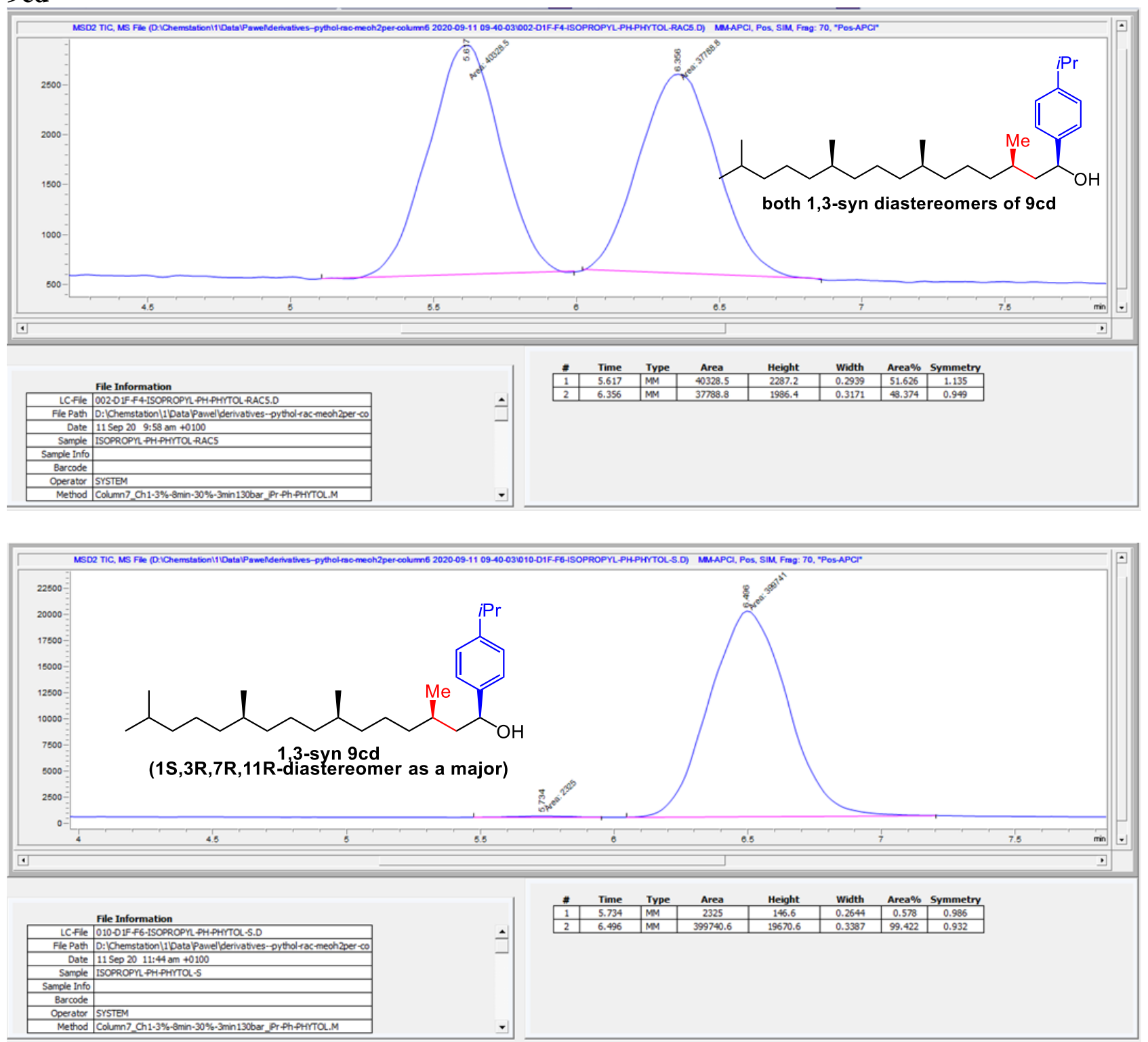


\section{9ce}
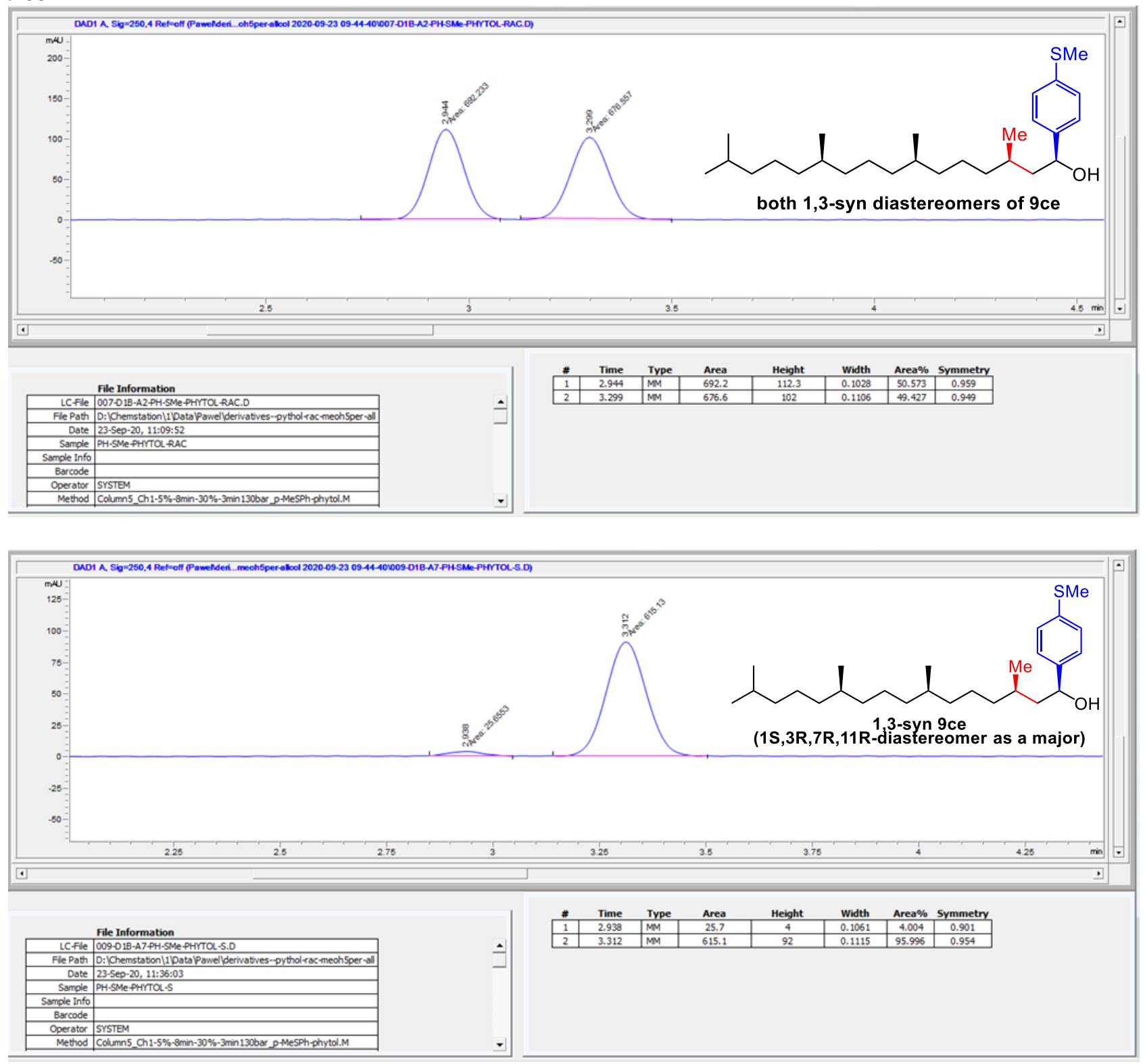


\section{9cf}
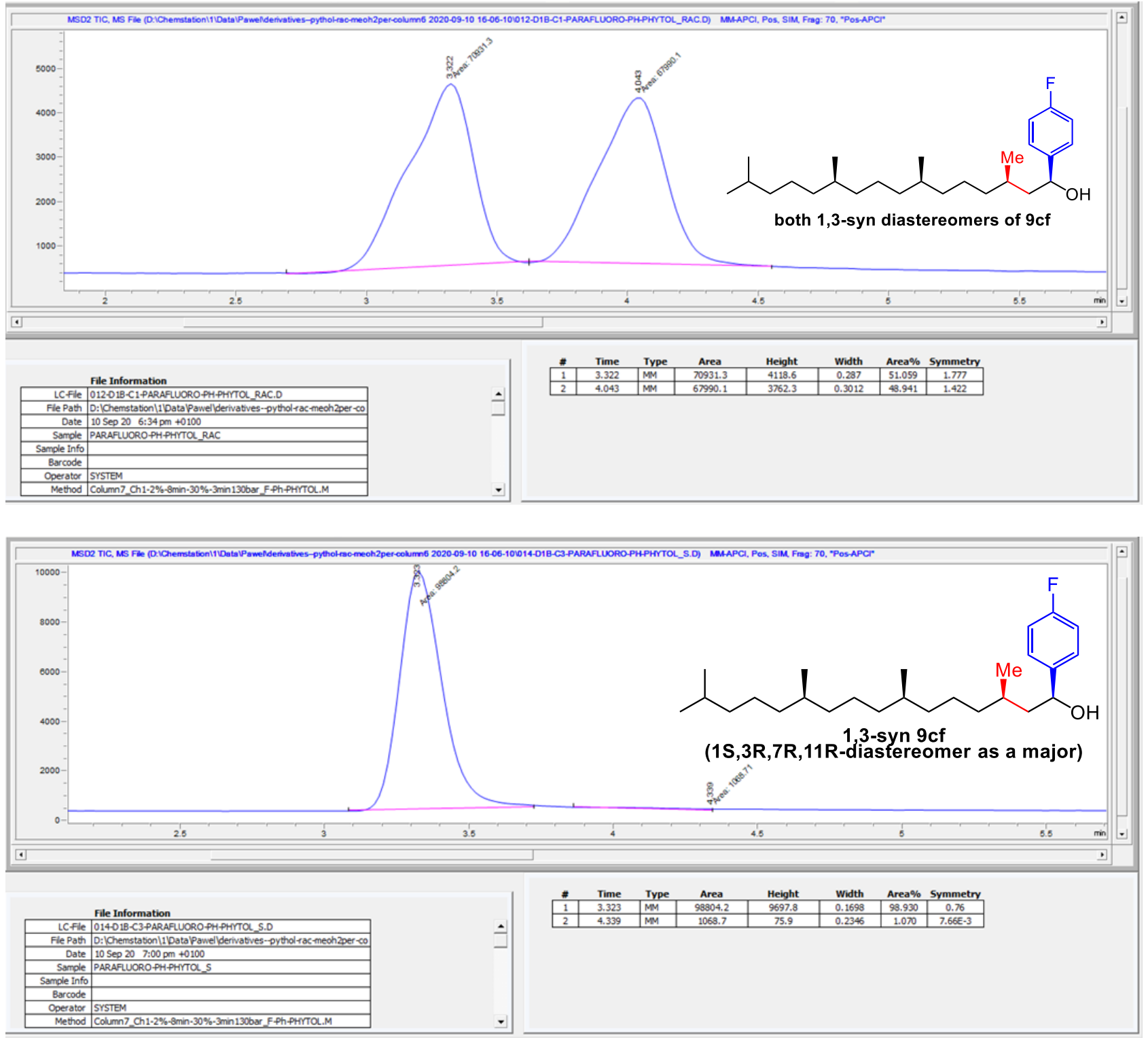

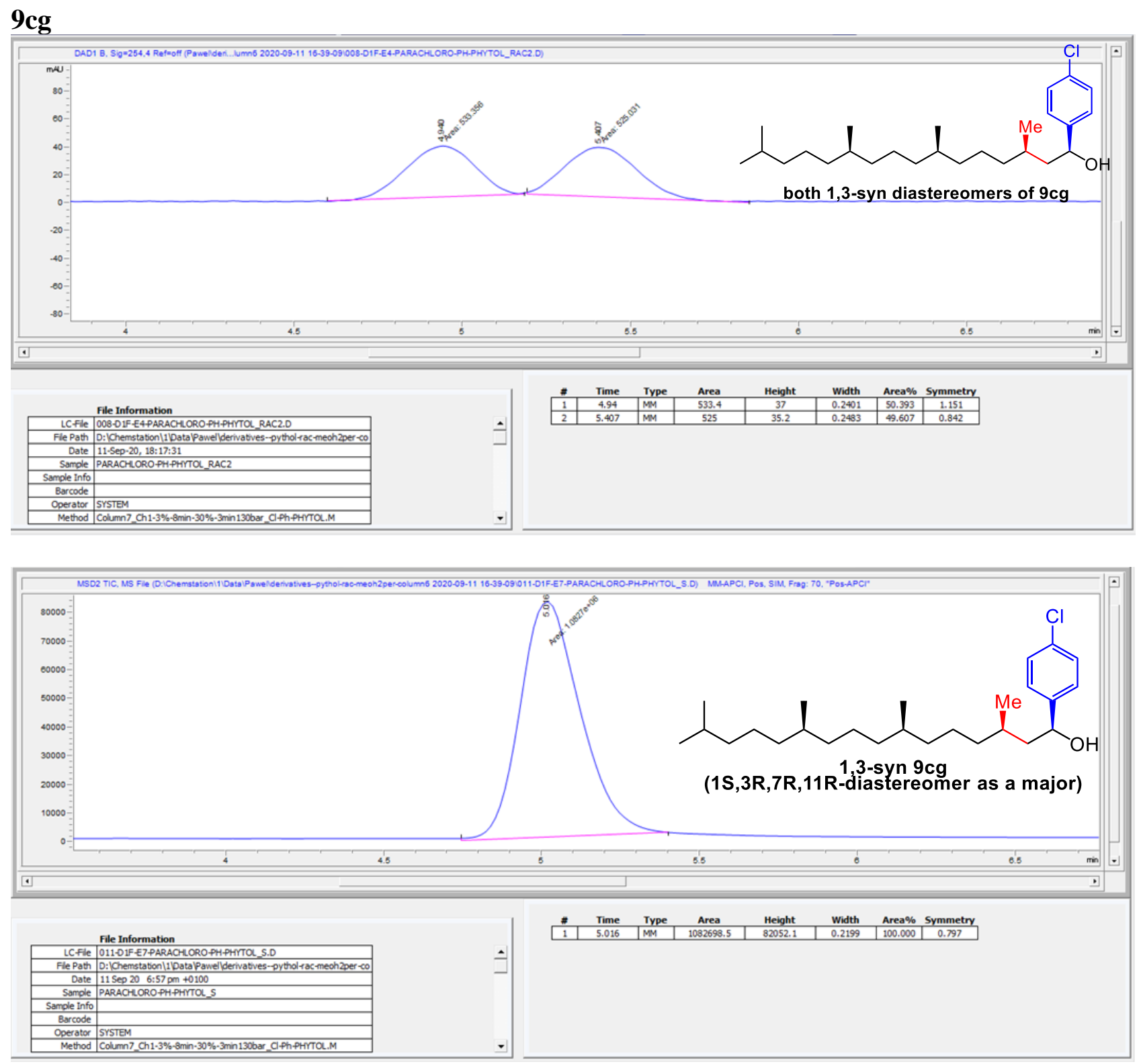


\section{9ch}
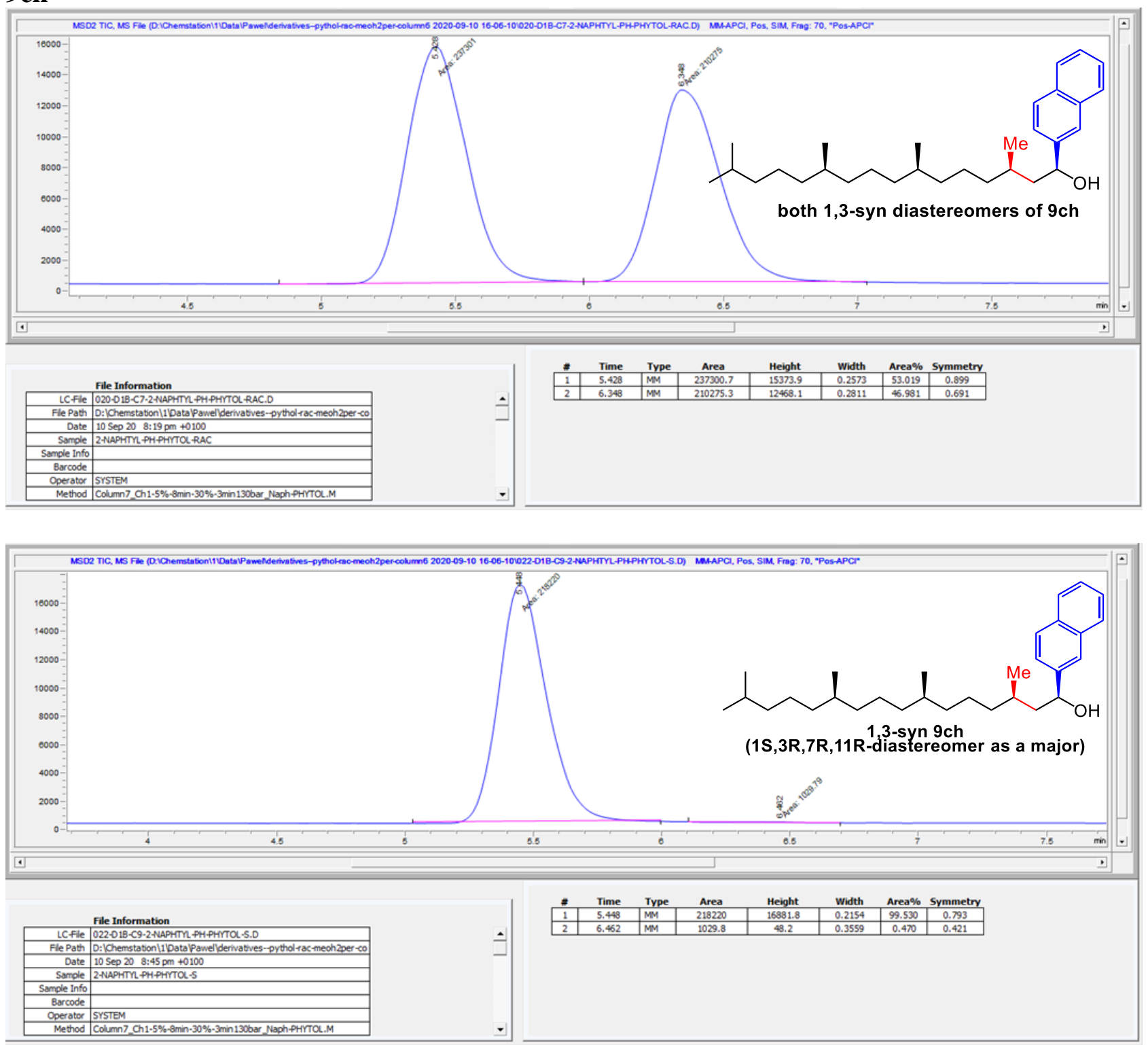

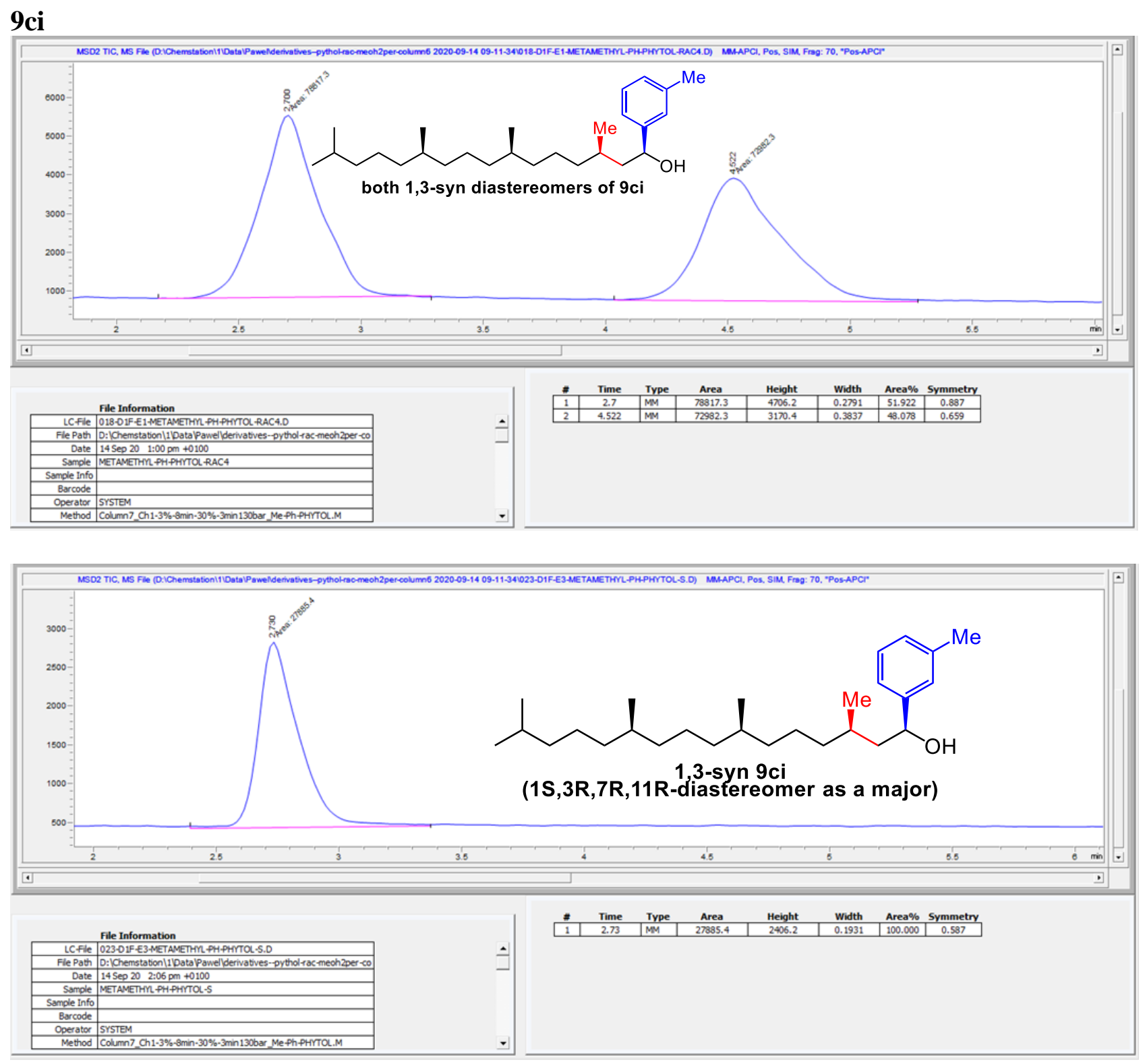
9cj
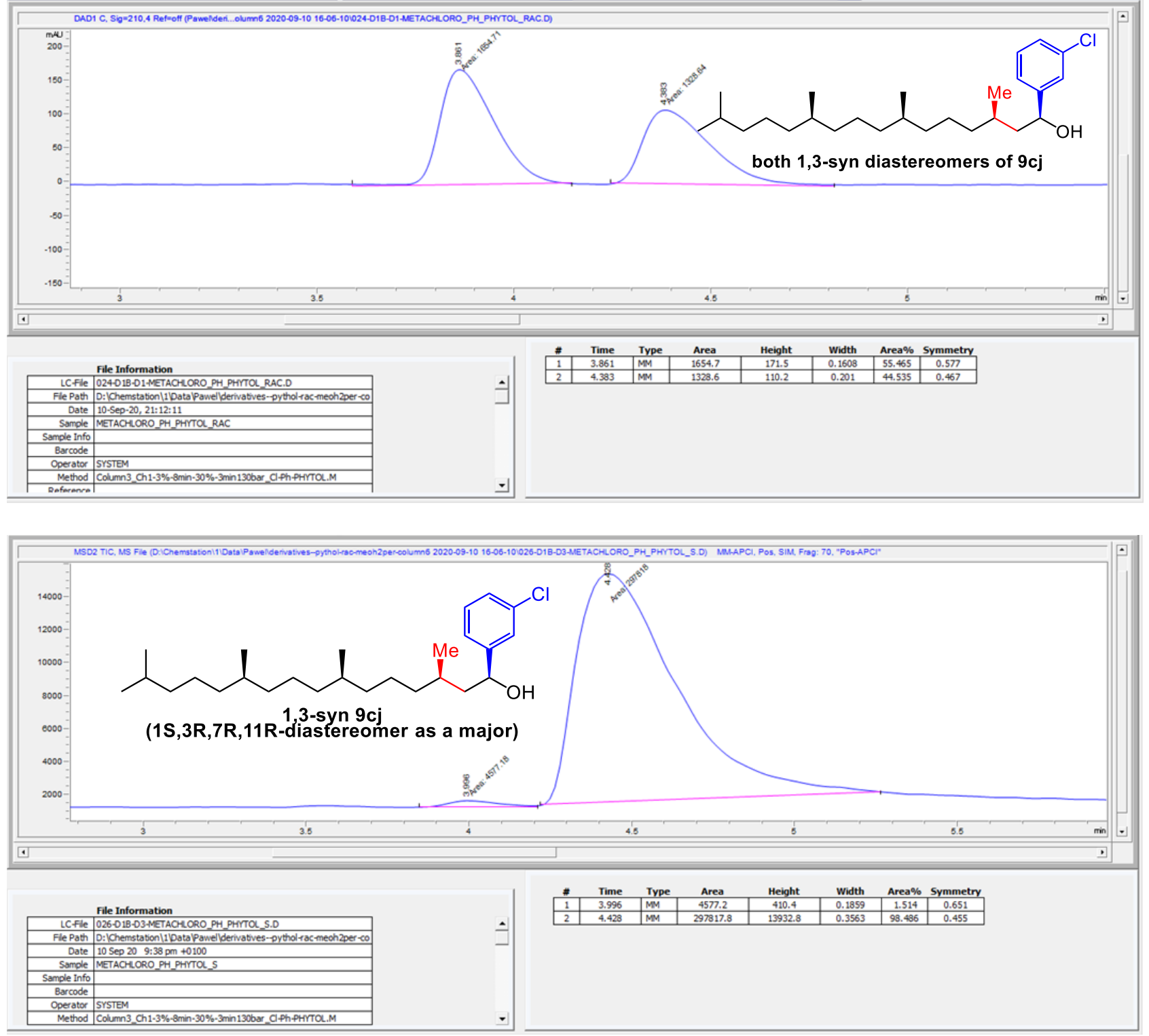


\section{HRMS DATA}

Found - top \& calculated - bottom.

3aa

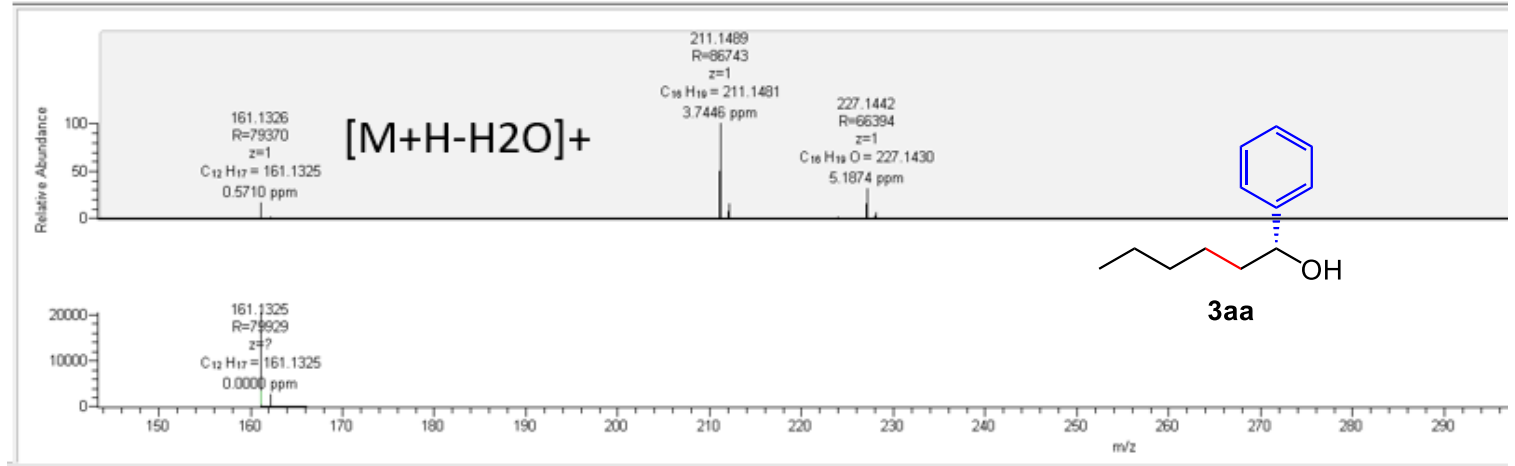

$3 a b$

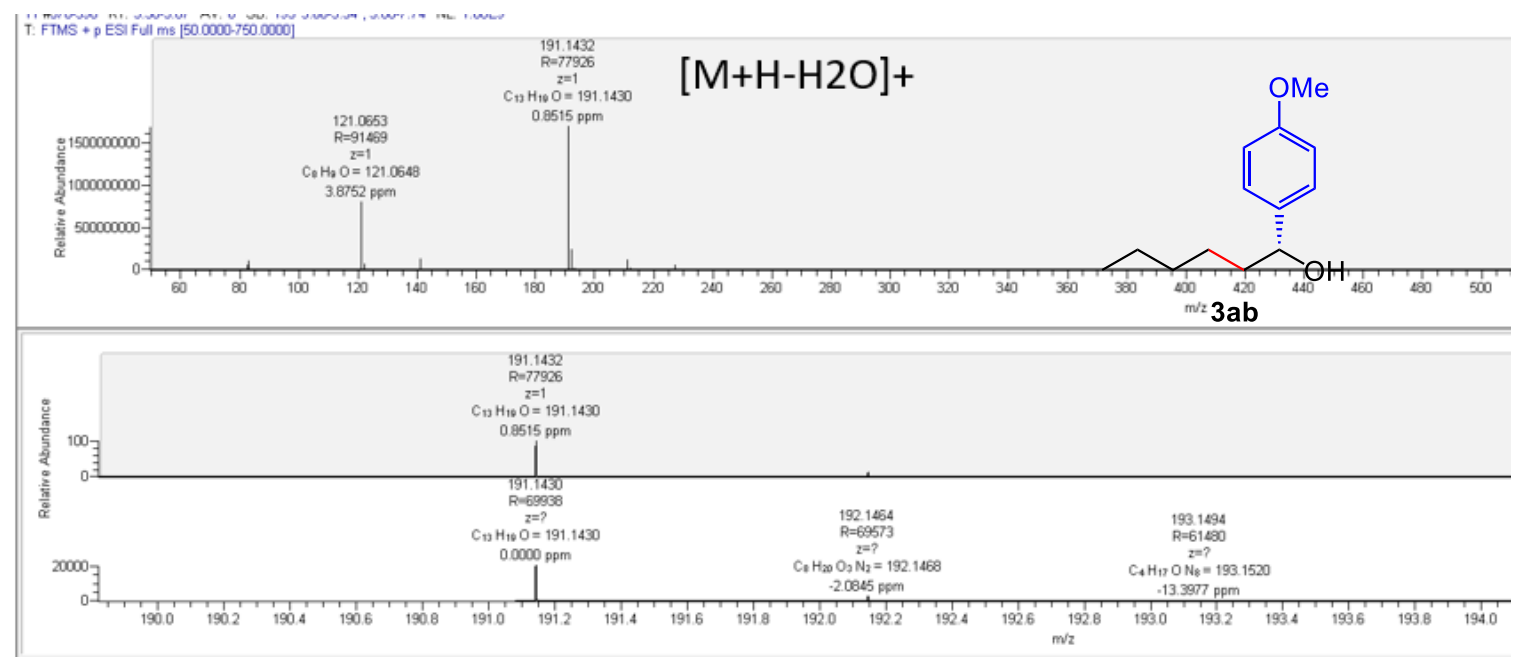




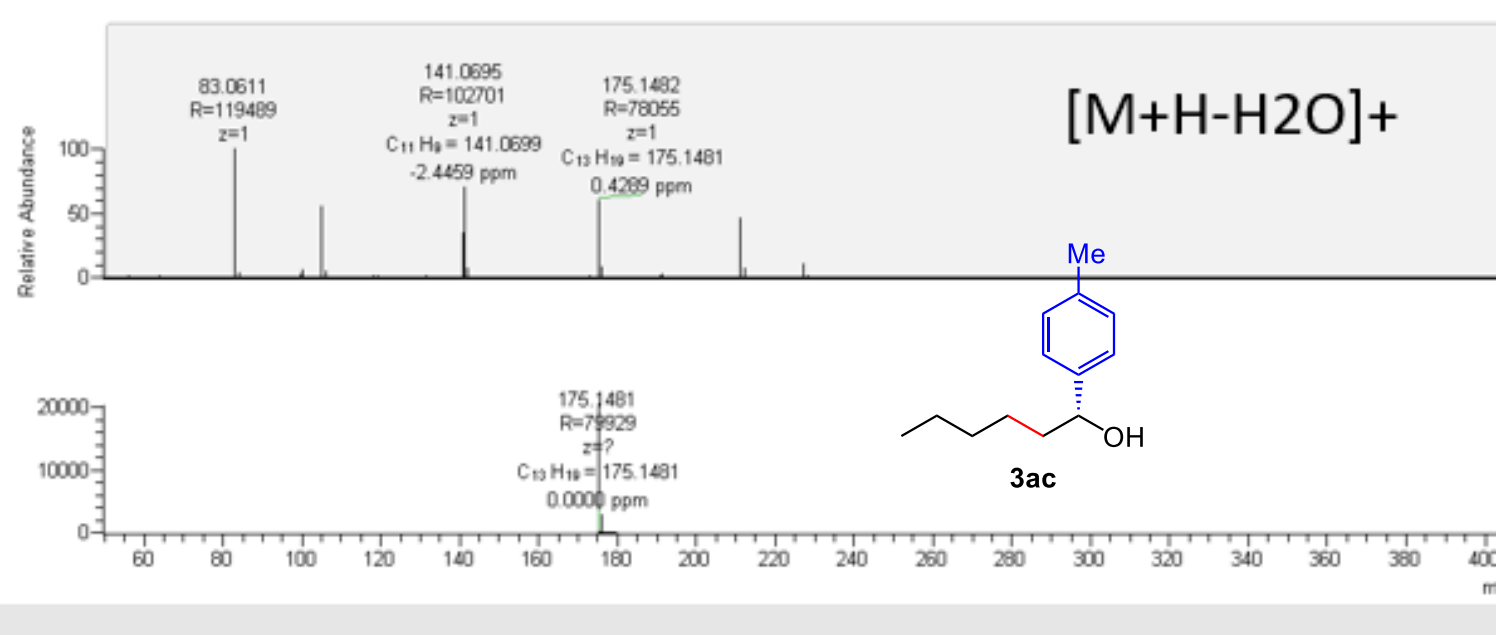

\section{3ad}

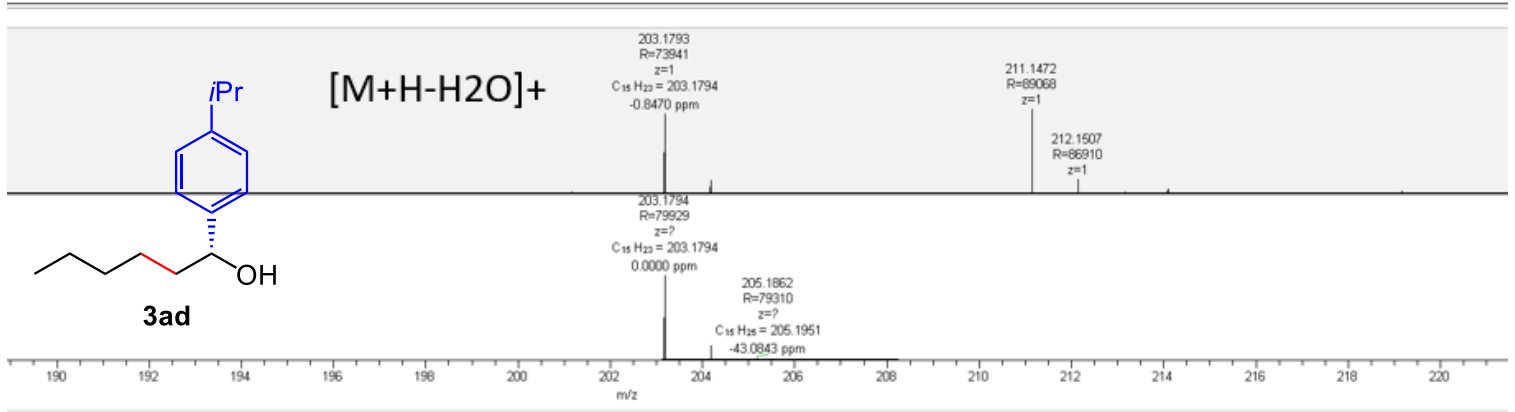

3af

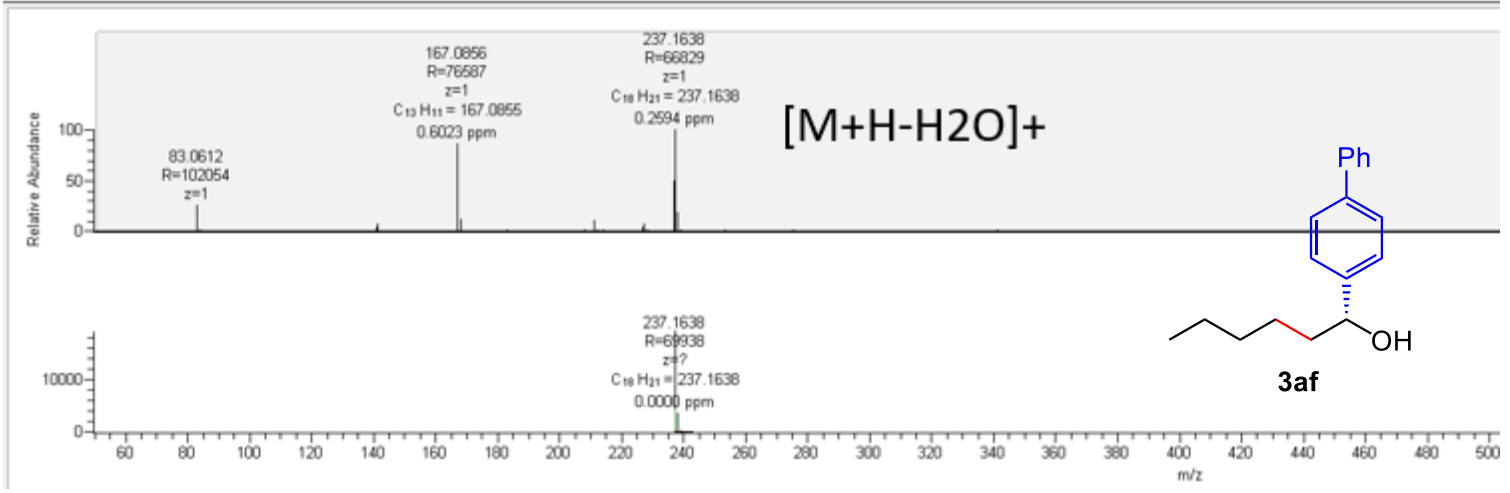


3ag

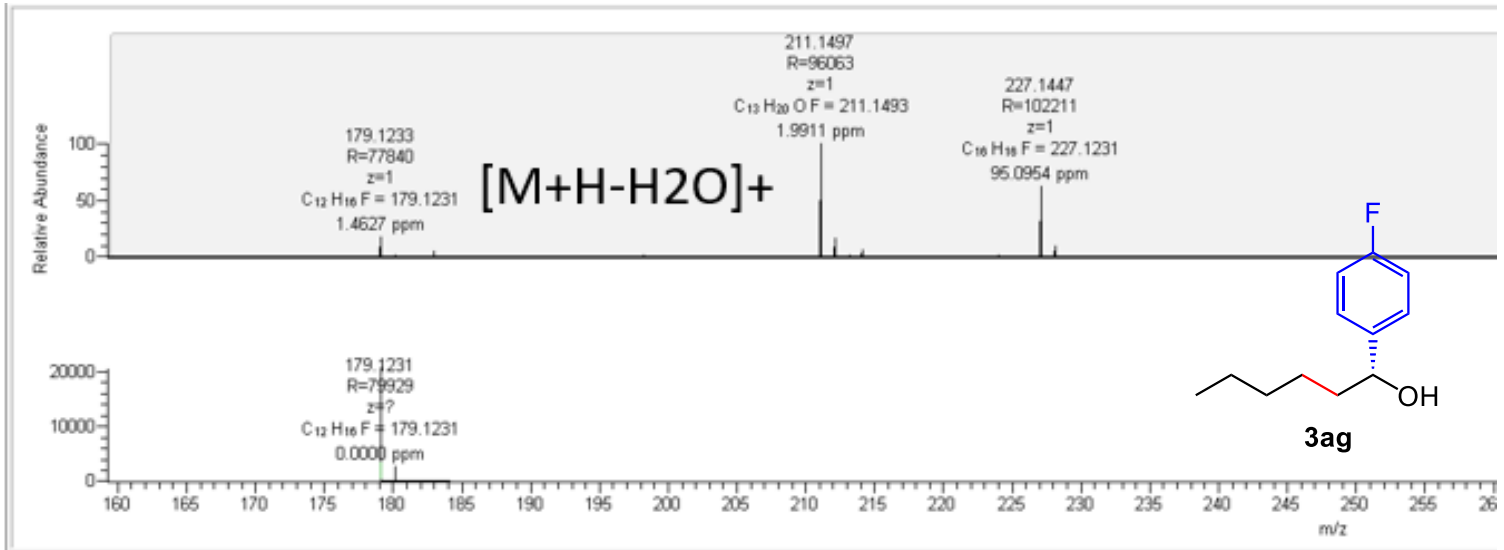

3ah

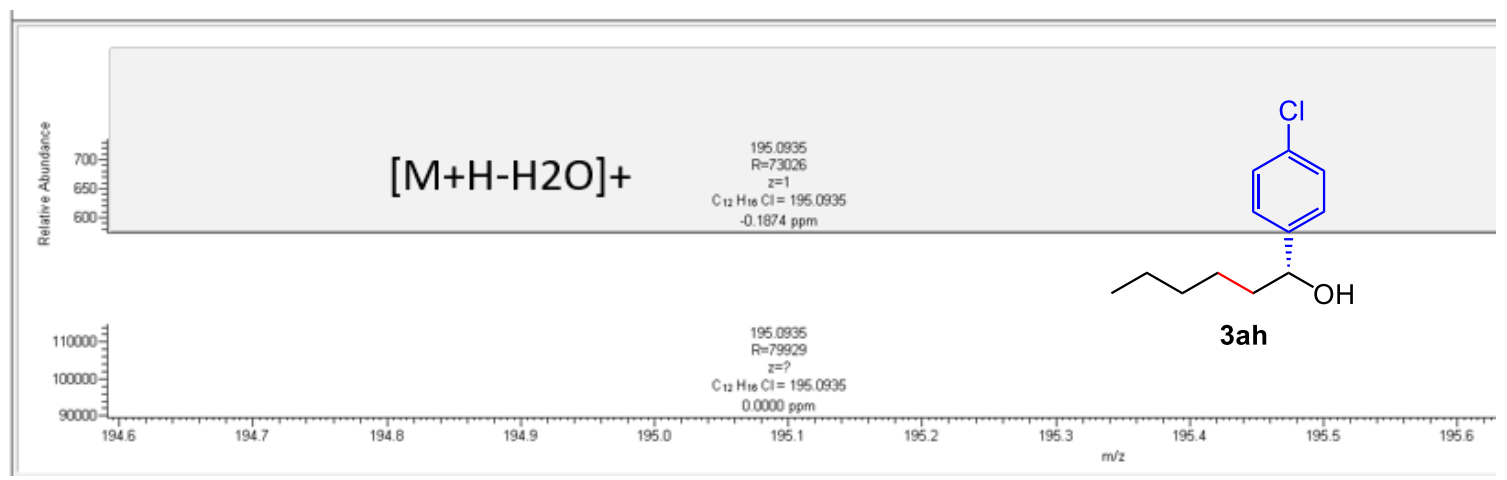

$3 a p$

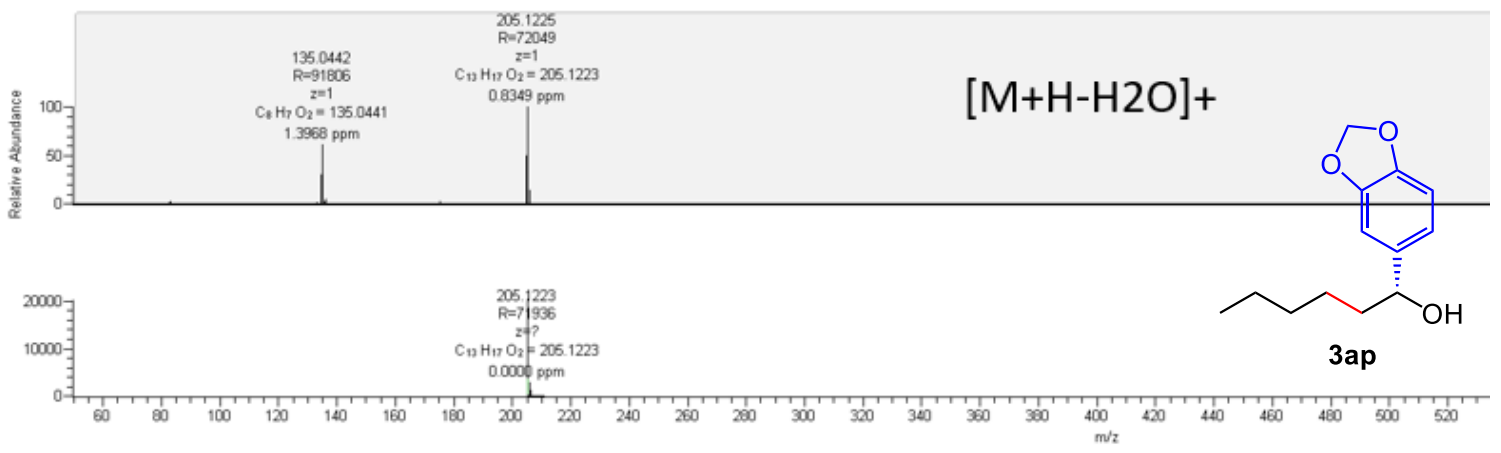


$3 a q$

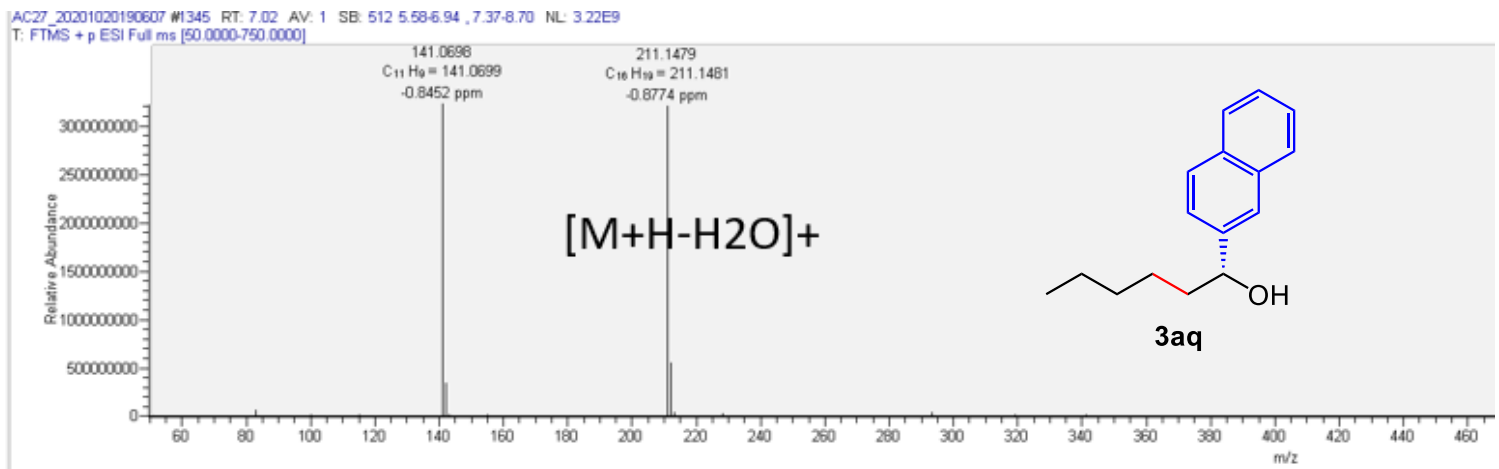

3at

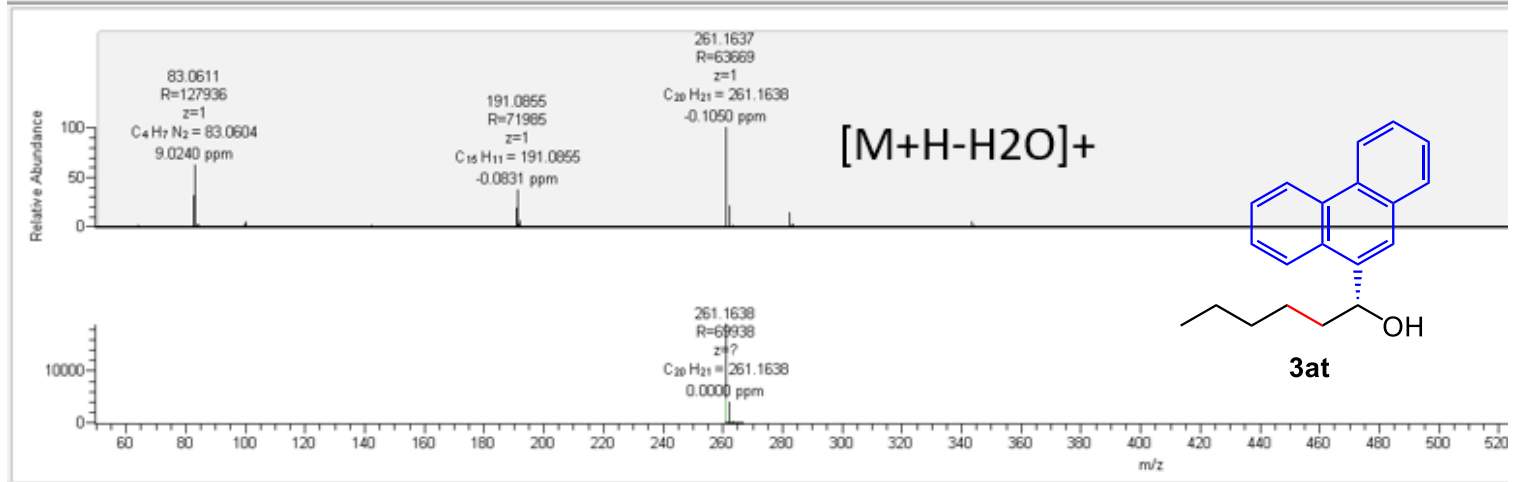

$6 a a$
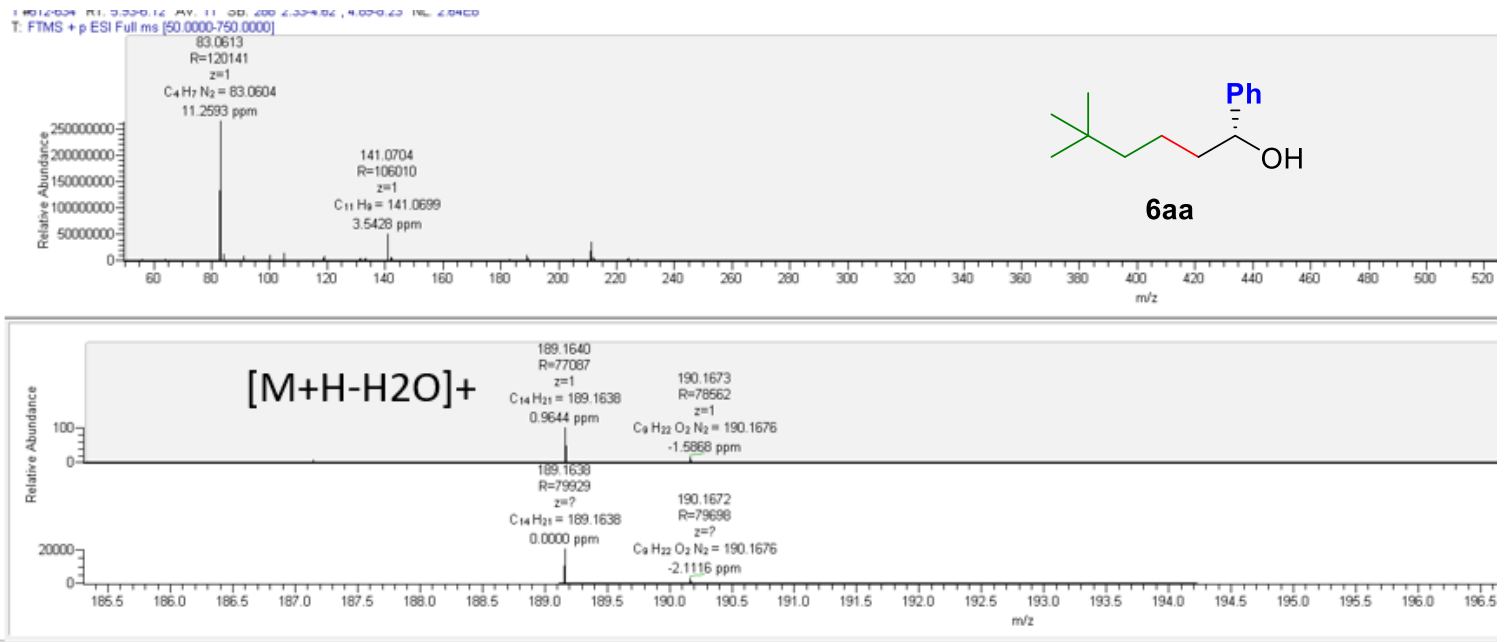
$6 c a$
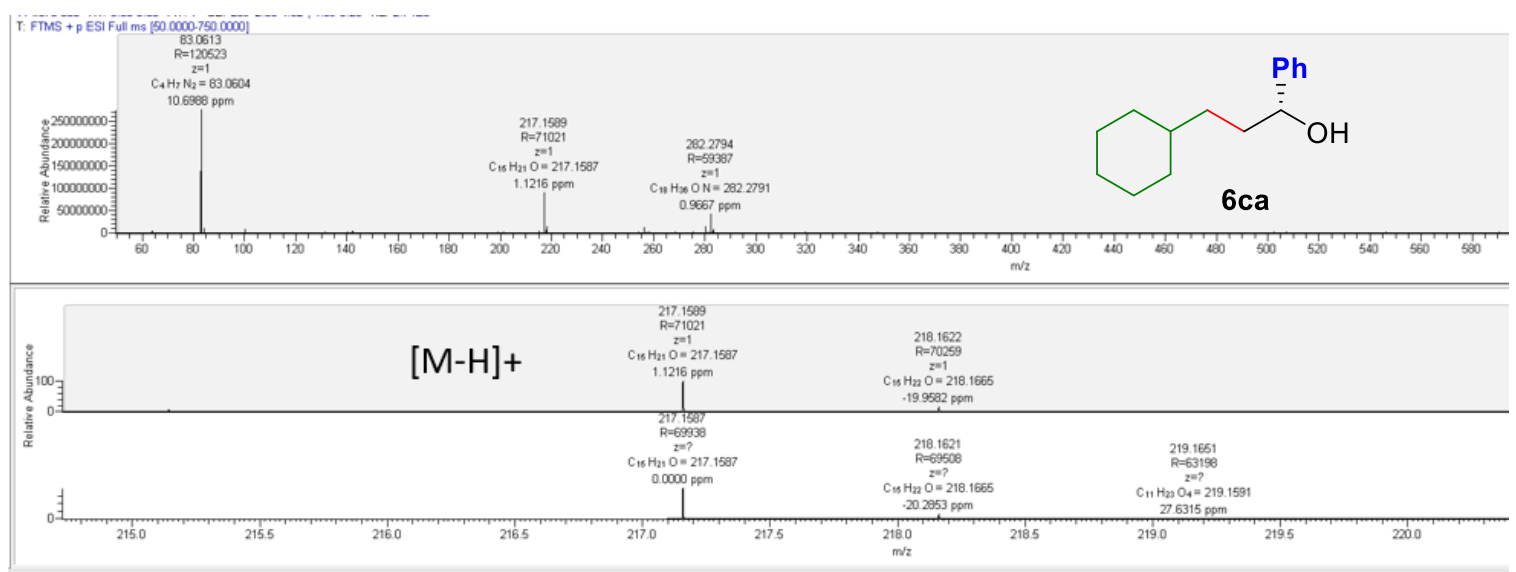

6ga
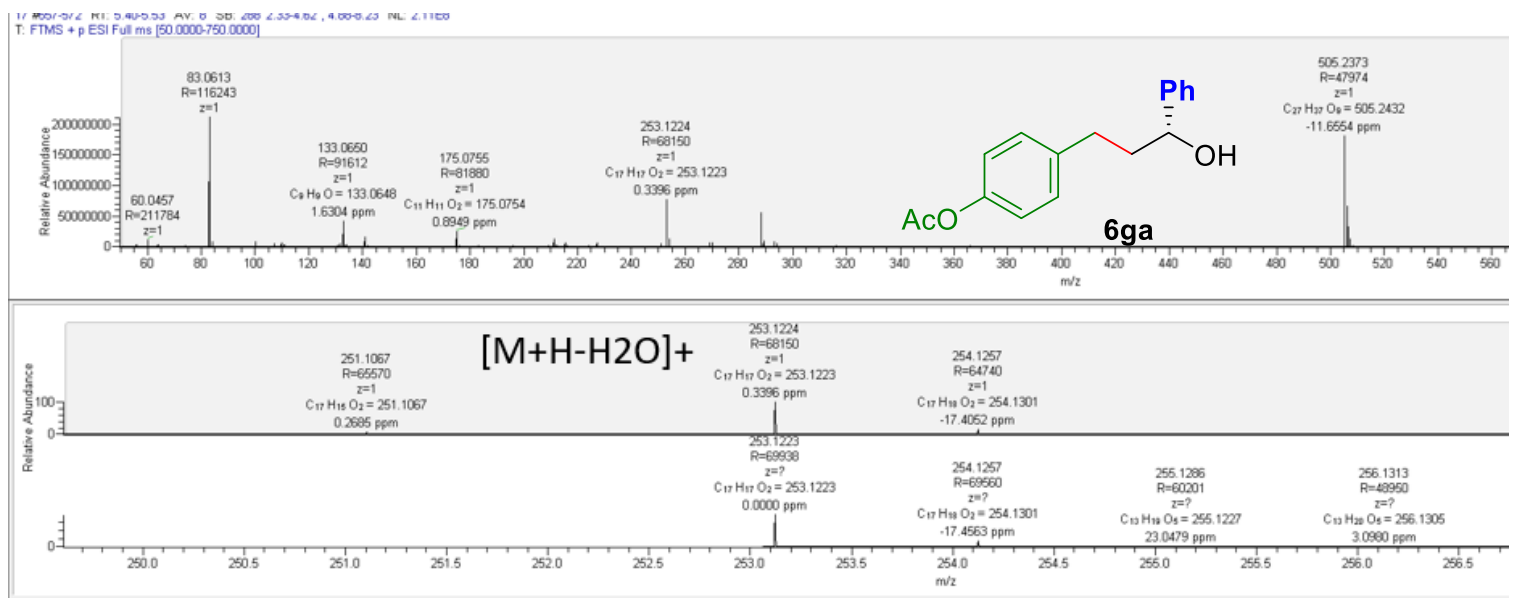

6 ha
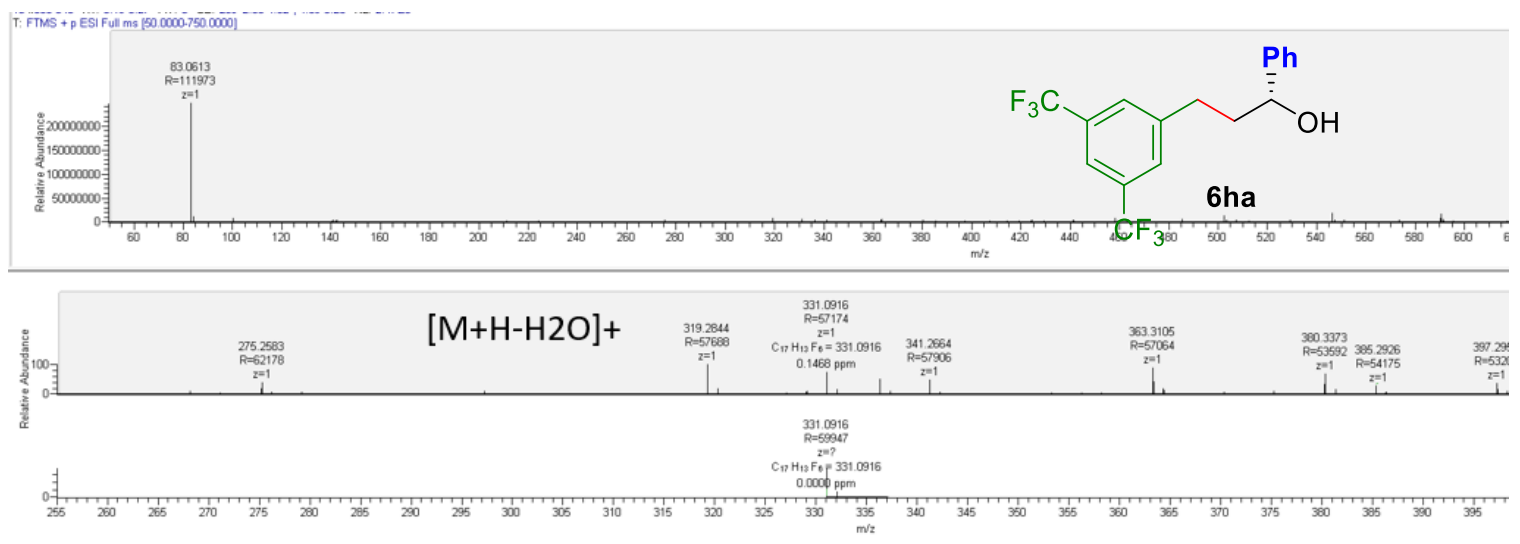
$6 a b$

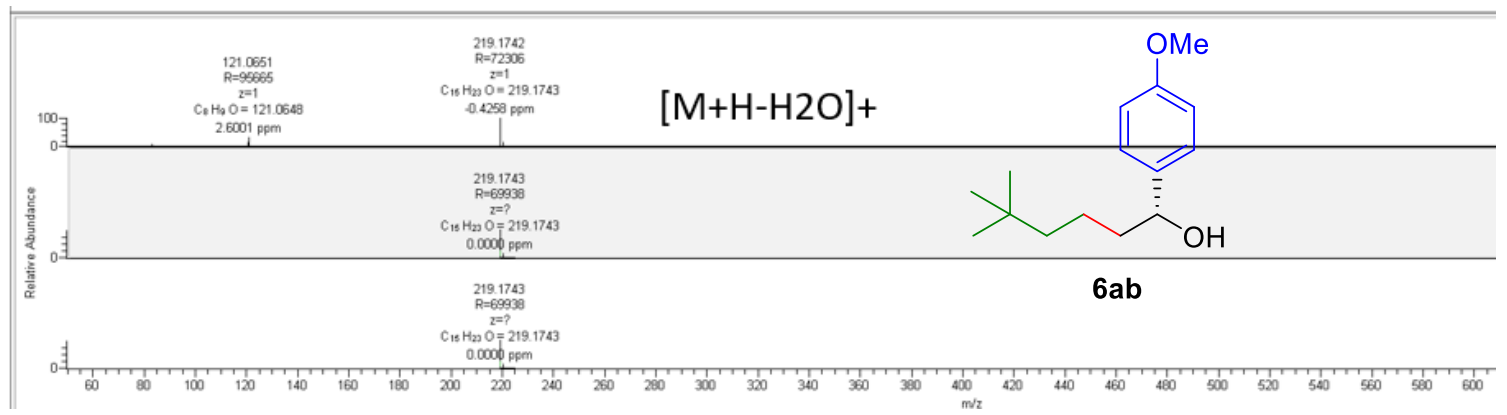

$6 a c$
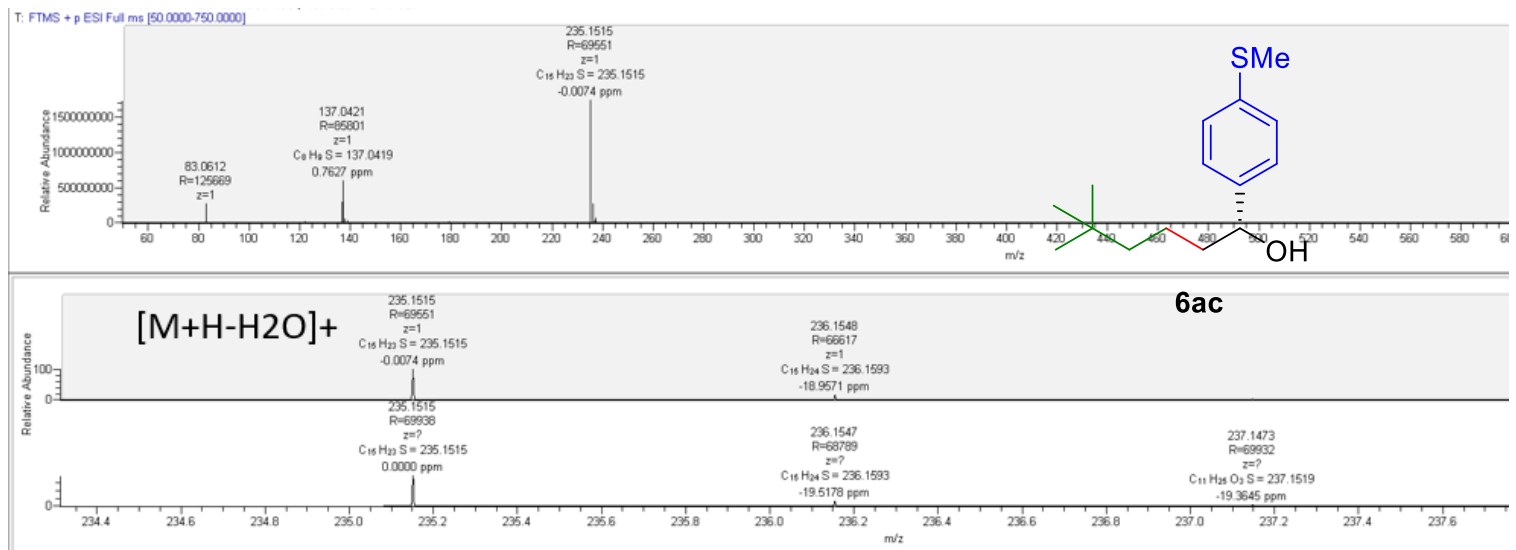

Gad

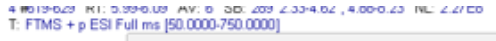
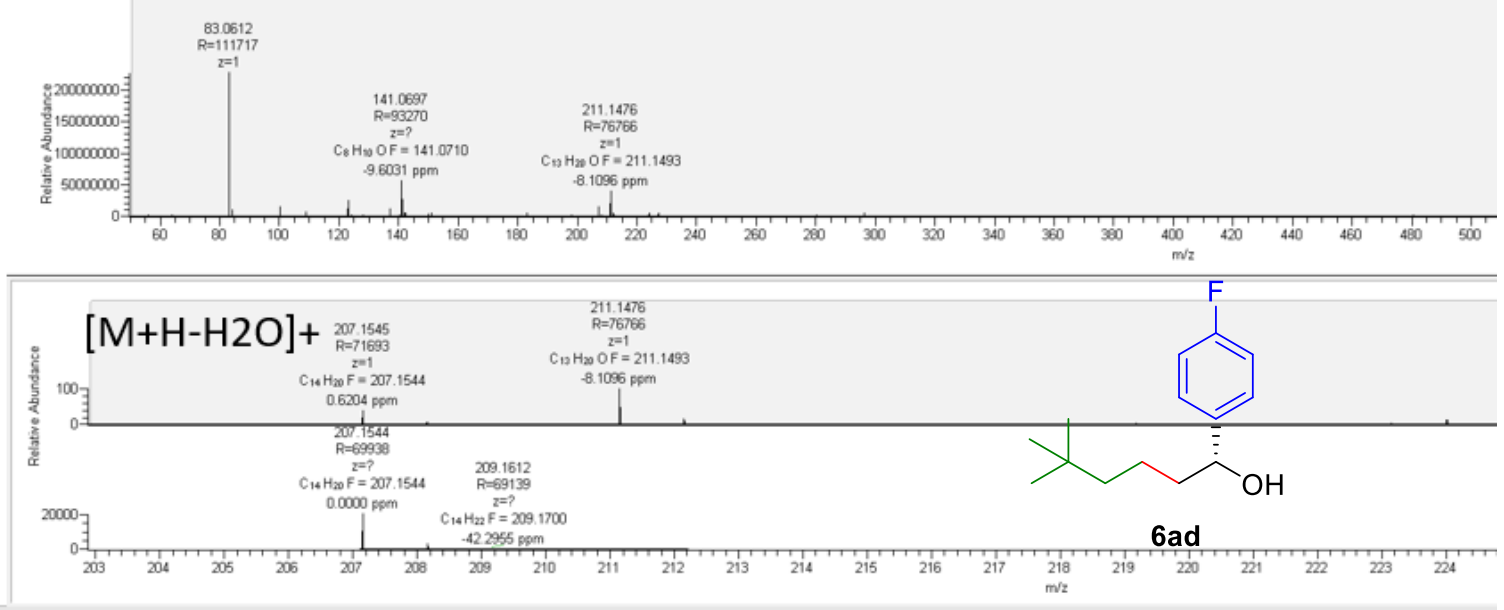
$6 a e$

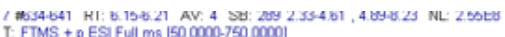
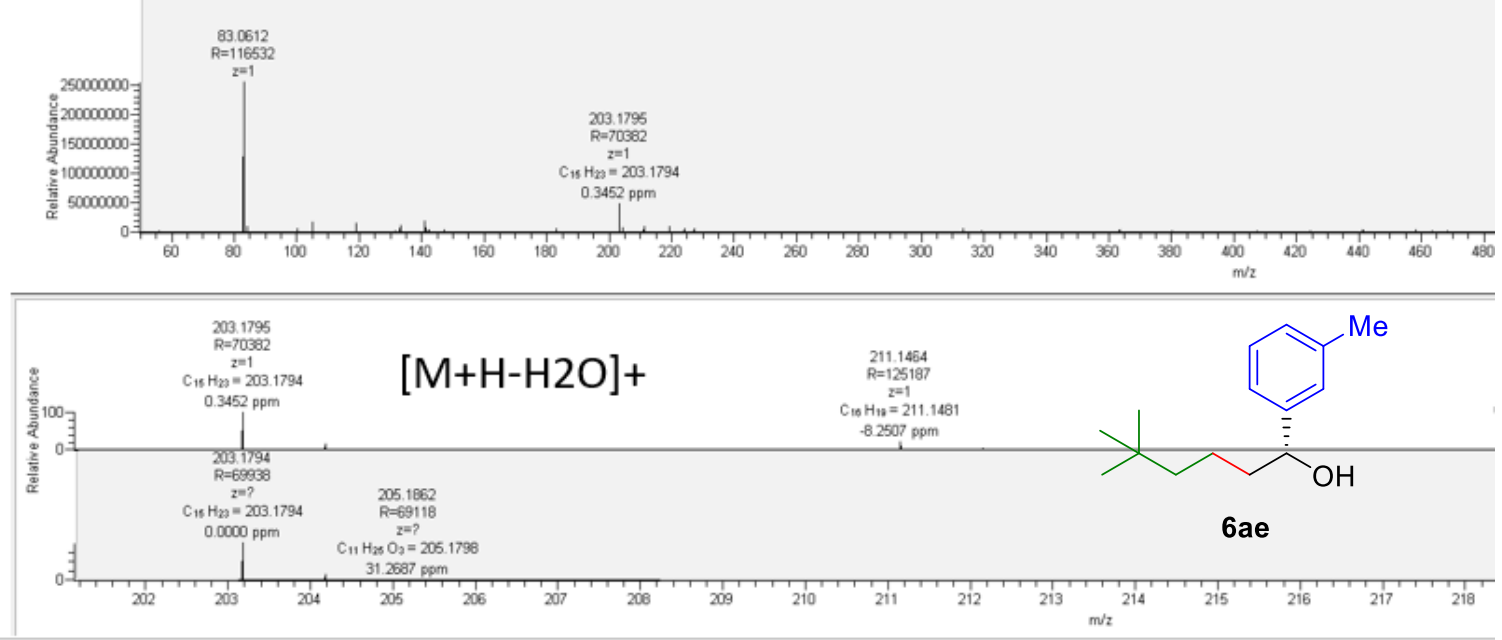

\section{6af}
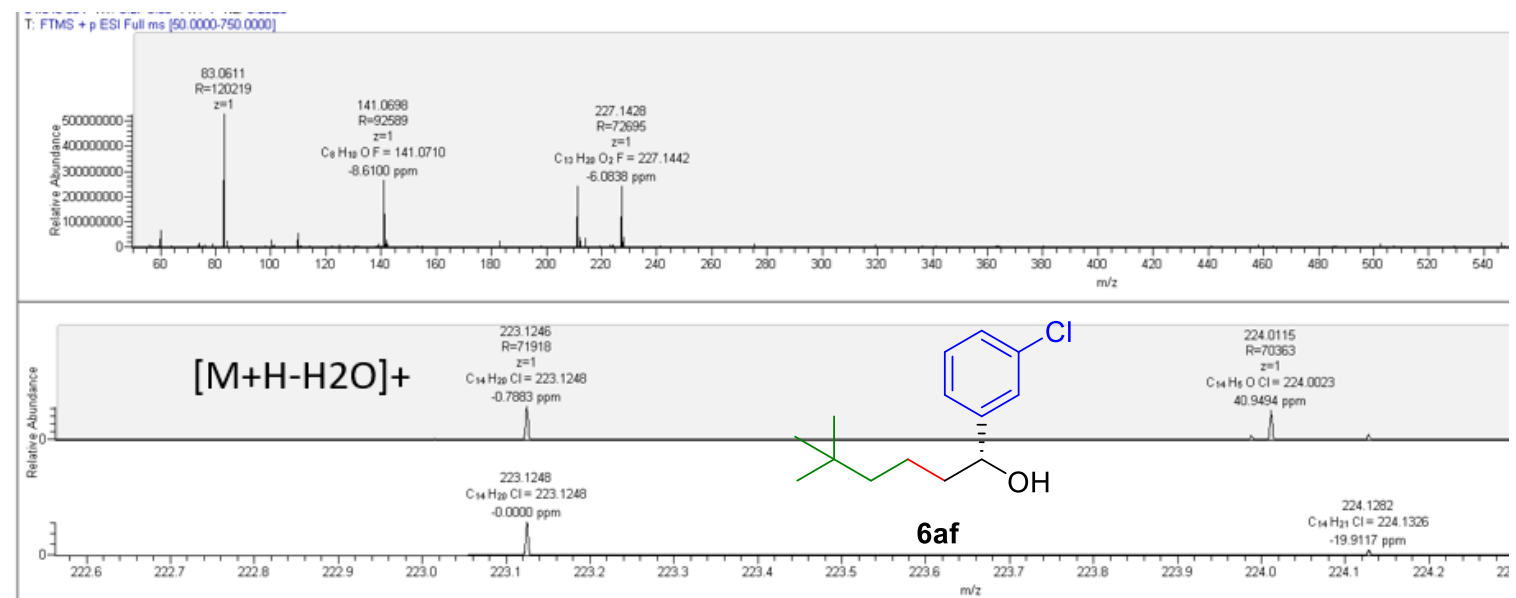
$6 a g$

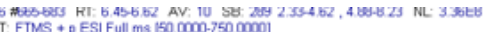
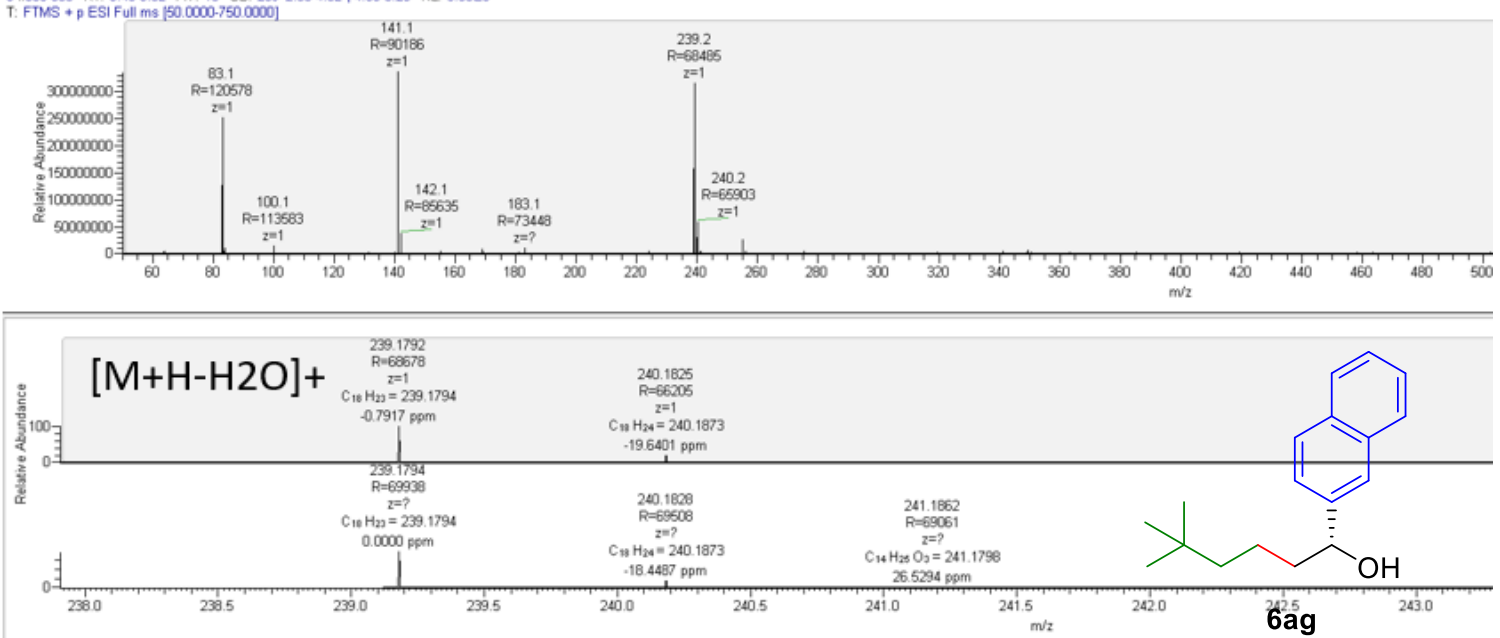

9aa

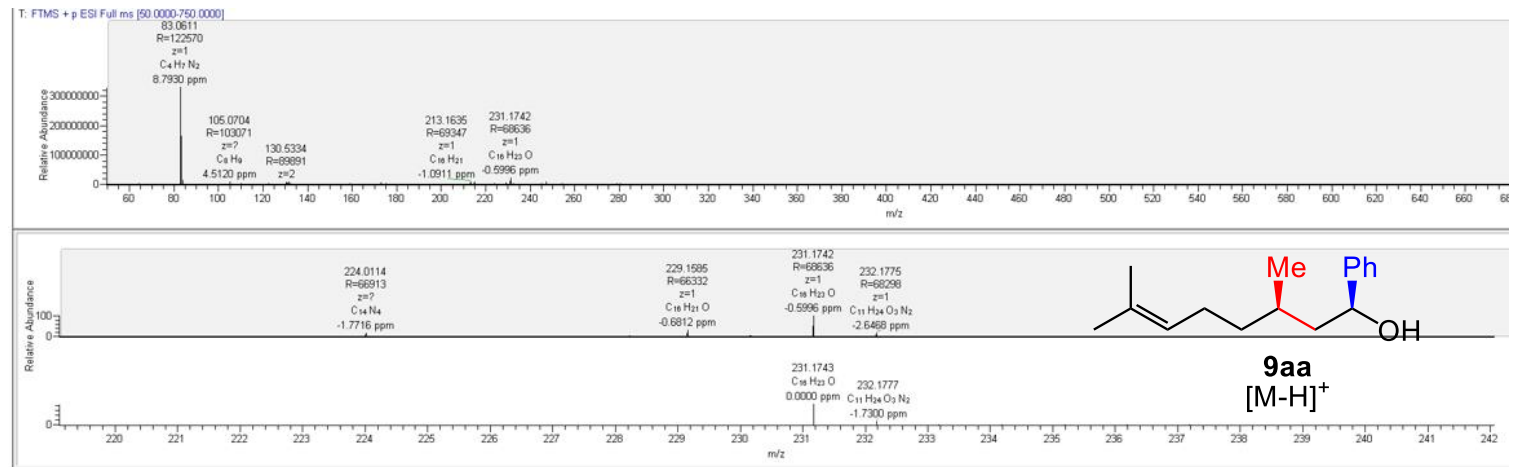

\section{9aa'}

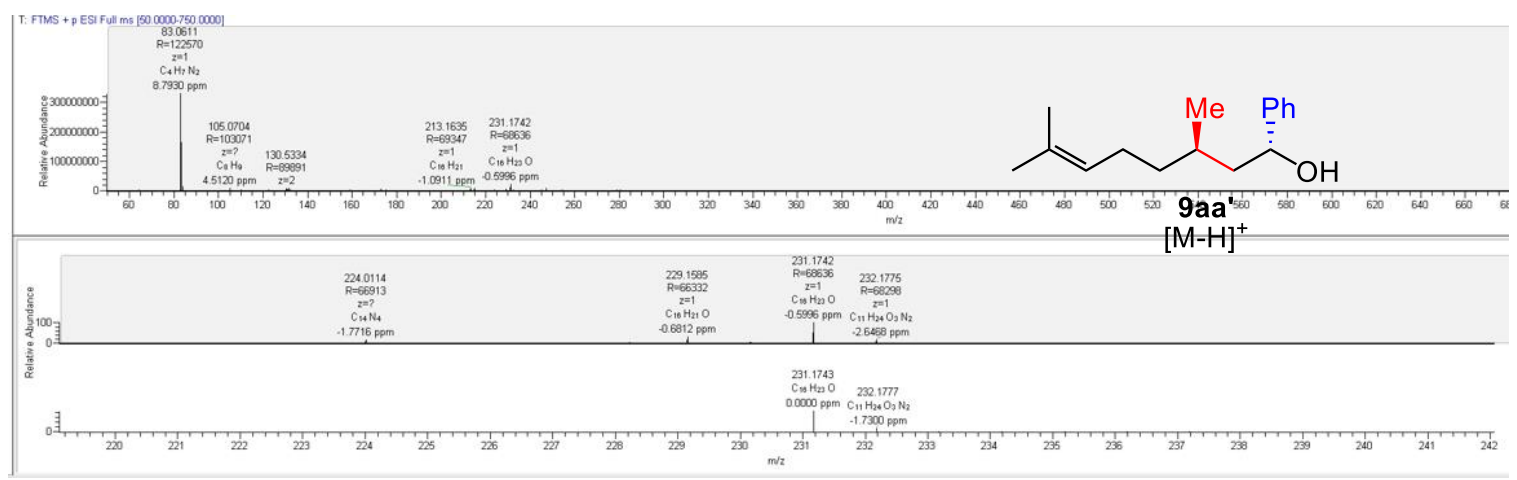




\section{9ba'}
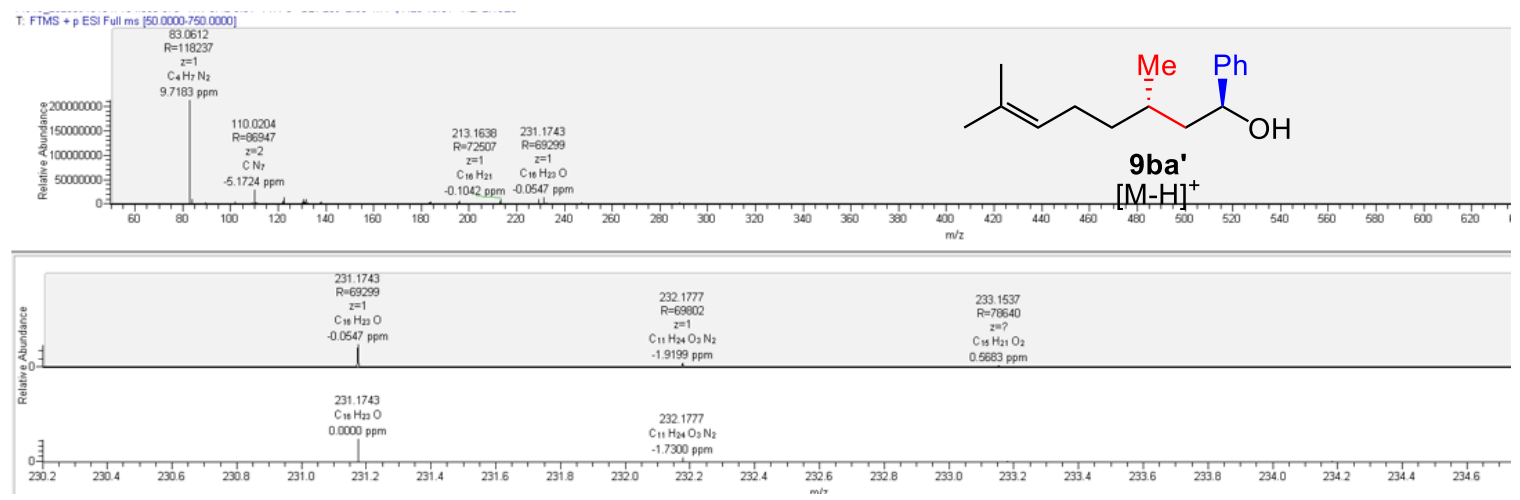

\section{9cc}
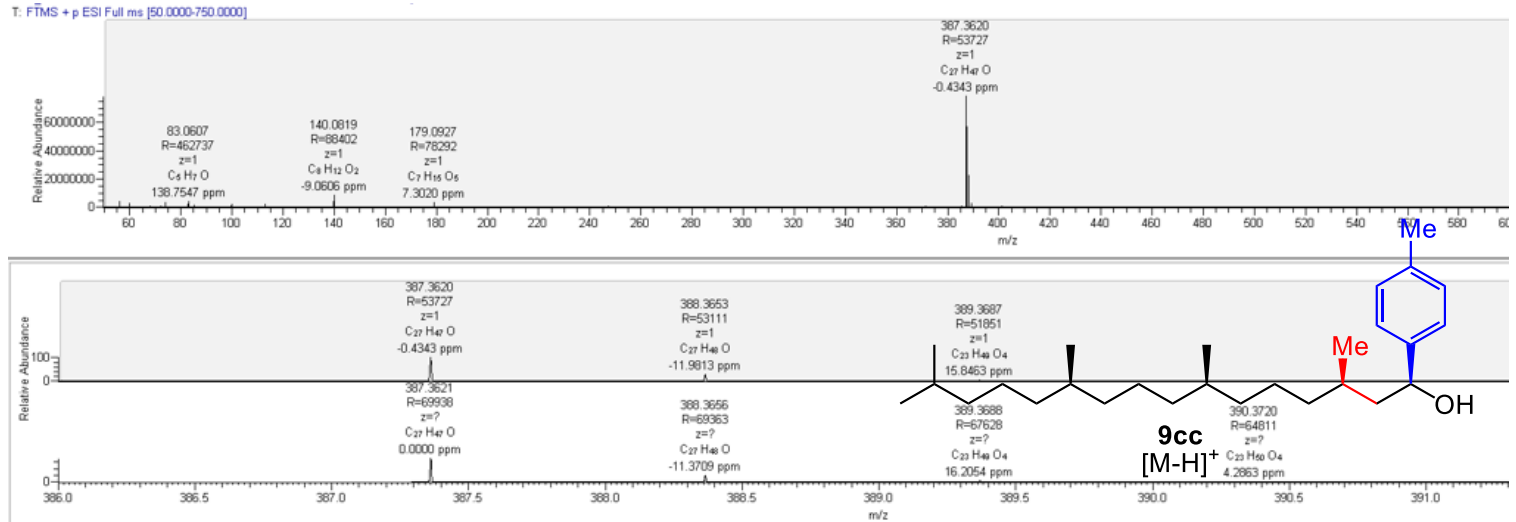

\section{$9 c g$}
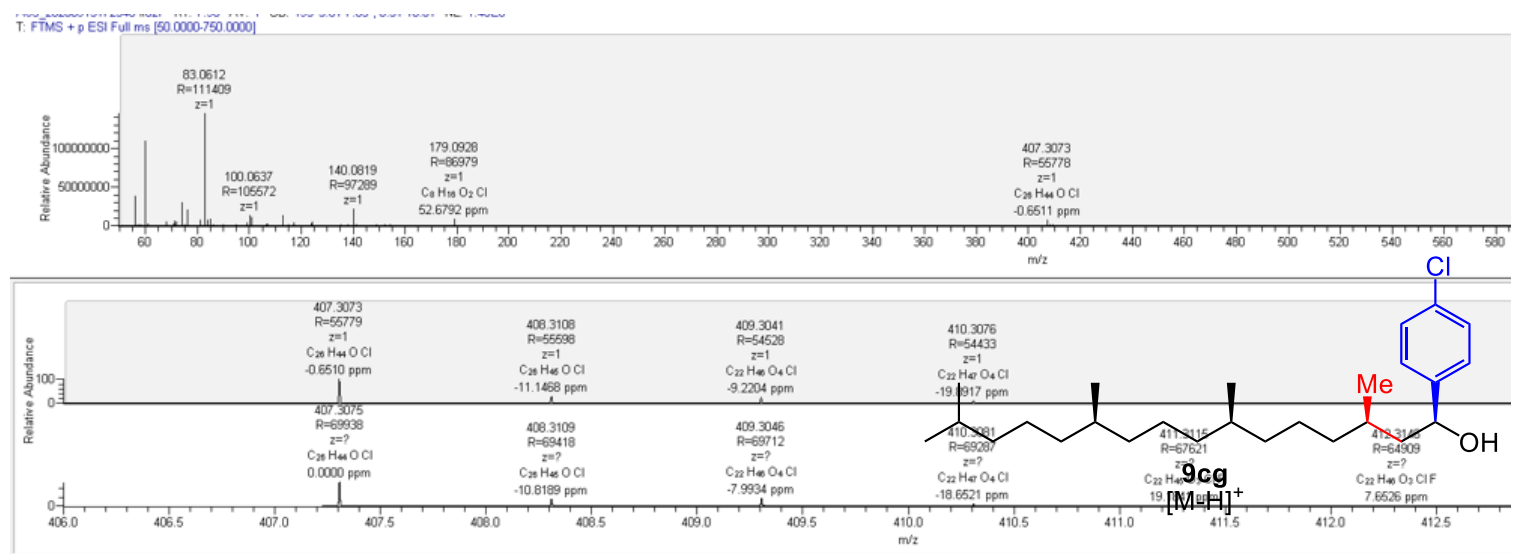


\section{9ch}
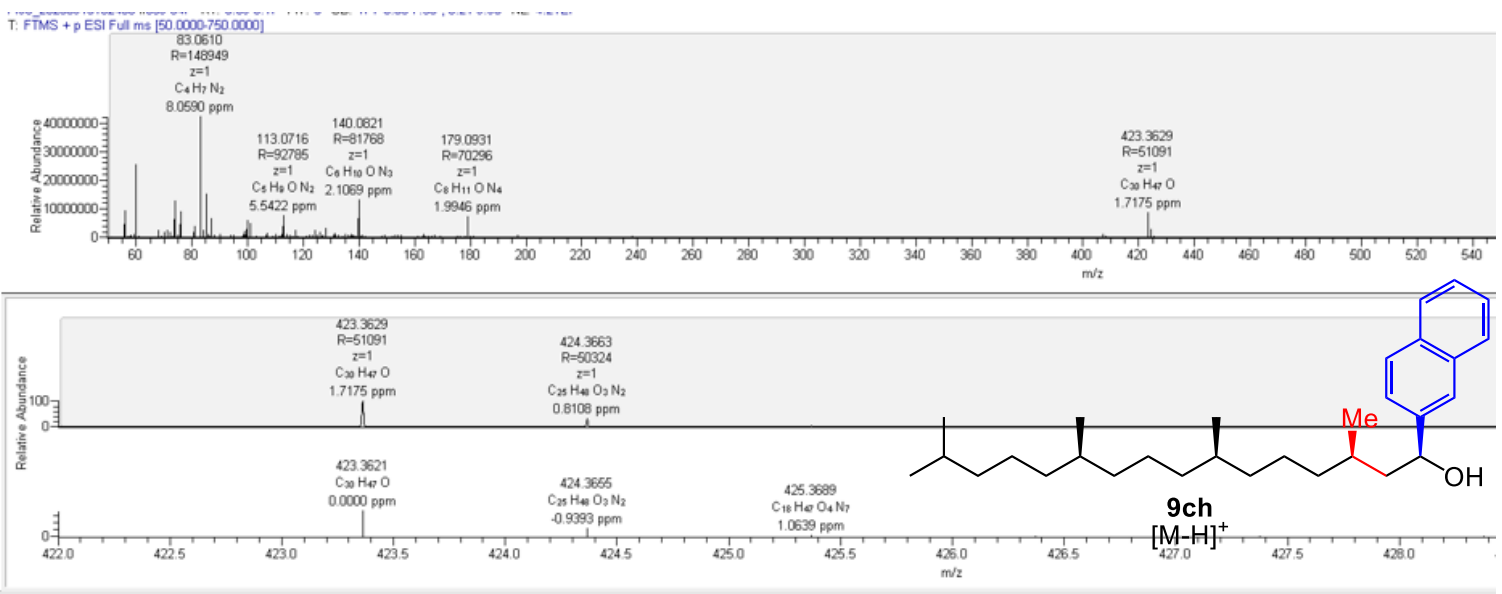

9cj

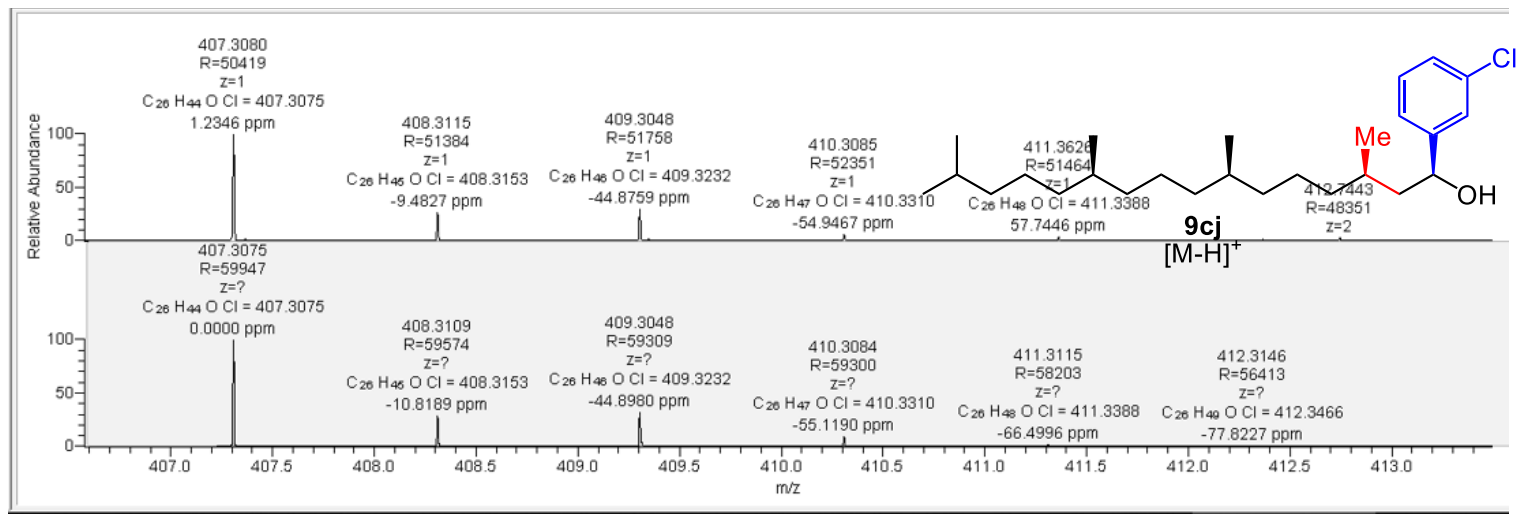




\section{REFERENCES}

(1) Kurihara, K.; Sugishita, N.; Oshita, K.; Piao, D.; Yamamoto, Y.; Miyaura, N. Enantioselective 1,4-Addition of Arylboronic Acids to $\alpha, \beta$-Unsaturated Carbonyl Compounds Catalyzed by Rhodium(I)-Chiral Phosphoramidite Complexes. $J$. Organomet. Chem. 2007, 692 (1-3), 428-435. https://doi.org/10.1016/j.jorganchem.2006.04.042.

(2) Zhu, T.-S.; Jin, S.-S.; Xu, M.-H. Rhodium-Catalyzed, Highly Enantioselective 1,2Addition of Aryl Boronic Acids to $\alpha$-Ketoesters and $\alpha$-Diketones Using Simple, Chiral Sulfur-Olefin Ligands. Angew. Chem. Int. Ed. 2012, 51 (3), 780-783. https://doi.org/10.1002/anie.201106972.

(3) Grotjahn, D. B.; Larsen, C. R.; Gustafson, J. L.; Nair, R.; Sharma, A. Extensive Isomerization of Alkenes Using a Bifunctional Catalyst: An Alkene Zipper. J. Am. Chem. Soc. 2007, 129 (31), 9592-9593. https://doi.org/10.1021/ja073457i.

(4) Arai, N.; Sato, K.; Azuma, K.; Ohkuma, T. Enantioselective Isomerization of Primary Allylic Alcohols into Chiral Aldehydes with the TolBinap/Dbapen/Ruthenium(II) Catalyst. Angew. Chem. Int. Ed. 2013, 52 (29), 7500-7504. https://doi.org/10.1002/anie.201303423.

(5) Manzini, S.; Nelson, D. J.; Nolan, S. P. A Highly Active Cationic Ruthenium Complex for Alkene Isomerisation: A Catalyst for the Synthesis of High Value Molecules. ChemCatChem 2013, 5 (10), 2848-2851. https://doi.org/10.1002/cctc.201300396.

(6) Pal, S.; Alizadeh, M.; Kilbinger, A. F. M. Telechelics Based on Catalytic Alternating Ring-Opening Metathesis Polymerization. ACS Macro Lett. 2019, 8 (10), 1396-1401. https://doi.org/10.1021/acsmacrolett.9b00750.

(7) Wang, Z. J.; Jackson, W. R.; Robinson, A. J. An Efficient Protocol for the CrossMetathesis of Sterically Demanding Olefins. Org. Lett. 2013, 15 (12), 3006-3009. https://doi.org/10.1021/ol401194h.

(8) Delay, F.; Ohloff, G. Syntheses and Absolute Configuration of (E)- and (Z)-?Bisabolenes. Helv. Chim. Acta 1979, 62 (2), 369-377. https://doi.org/10.1002/hlca.19790620203.

(9) Yamamoto, Y.; Shirai, T.; Watanabe, M.; Kurihara, K.; Miyaura, N. Ru/MeBIPAM-Catalyzed Asymmetric Addition of Arylboronic Acids to Aliphatic Aldehydes and $\alpha$-Ketoesters. Molecules 2011, 16 (6), 5020-5034. https://doi.org/10.3390/molecules16065020.

(10) Onodera, G.; Nishibayashi, Y.; Uemura, S. Ir- and Ru-Catalyzed Sequential Reactions: Asymmetric $\alpha$-Alkylative Reduction of Ketones with Alcohols. Angew. Chem. Int. Ed. 2006, 45 (23), 3819-3822. https://doi.org/10.1002/anie.200600677.

(11) Adair, G. R. A.; Williams, J. M. J. A Catalytic Deracemisation of Alcohols. Chem. Commun. 2007, No. 25, 2608. https://doi.org/10.1039/b704956k.

(12) Hatano, M.; Gouzu, R.; Mizuno, T.; Abe, H.; Yamada, T.; Ishihara, K. Catalytic Enantioselective Alkyl and Aryl Addition to Aldehydes and Ketones with Organozinc Reagents Derived from Alkyl Grignard Reagents or Arylboronic Acids. Catal. Sci. Technol. 2011, 1 (7), 1149. https://doi.org/10.1039/c1cy00108f.

(13) Zhang, Y.; Torker, S.; Sigrist, M.; Bregović, N.; Dydio, P. Binuclear Pd(I)-Pd(I) Catalysis Assisted by Iodide Ligands for Selective Hydroformylation of Alkenes 
and Alkynes. J. Am. Chem. Soc. 2020, 142 (42), 18251-18265.

https://doi.org/10.1021/jacs.0c09254.

(14) Johnson, C. R.; Tait, B. D. A Cerium(III) Modification of the Peterson Reaction: Methylenation of Readily Enolizable Carbonyl Compounds. J. Org. Chem. 1987, 52 (2), 281-283. https://doi.org/10.1021/jo00378a024. 